\title{
WestVirginiaUniversity
}

THE RESEARCH REPOSITORY @ WVU

Graduate Theses, Dissertations, and Problem Reports

2014

\section{Mechanical Stratigraphy of the Utica Shale, Eastern New York State}

John Brockman

Follow this and additional works at: https://researchrepository.wvu.edu/etd

\section{Recommended Citation}

Brockman, John, "Mechanical Stratigraphy of the Utica Shale, Eastern New York State" (2014). Graduate Theses, Dissertations, and Problem Reports. 5260.

https://researchrepository.wvu.edu/etd/5260

This Thesis is protected by copyright and/or related rights. It has been brought to you by the The Research Repository @ WVU with permission from the rights-holder(s). You are free to use this Thesis in any way that is permitted by the copyright and related rights legislation that applies to your use. For other uses you must obtain permission from the rights-holder(s) directly, unless additional rights are indicated by a Creative Commons license in the record and/ or on the work itself. This Thesis has been accepted for inclusion in WVU Graduate Theses, Dissertations, and Problem Reports collection by an authorized administrator of The Research Repository @ WVU. For more information, please contact researchrepository@mail.wvu.edu. 


\title{
Mechanical Stratigraphy of the Utica Shale, Eastern New York State
}

\author{
John Brockman \\ Thesis submitted to the \\ Eberly College of Arts and Sciences \\ at West Virginia University \\ in partial fulfillment of the requirements for the degree of \\ Master of Science in \\ Geology
}

Dr. Ryan Shackleton, Ph.D., Chair

Dr. Kathleen Benison, Ph.D.

Dr. Timothy Carr, Ph.D.

Department of Geology and Geography

Morgantown, West Virginia

2014

Keywords: Utica Shale; Mechanical Stratigraphy; Fractures; Flat Creek Shale; Dolgeville Formation; New York; Ordovician

Copyright 2014 John Brockman 


\section{ABSTRACT \\ Mechanical Stratigraphy of the Utica Shale, Eastern New York State \\ John Brockman}

The mechanical stratigraphy of the Upper Ordovician Utica Shale is characterized by studying outcrops and core located in Montgomery County, eastern New York State. Previous studies of the Utica Shale in New York State have focused on characterizing fracture orientations, distinguishing fracture generations, and establishing a relationship between fracture density and proximity to faults, but fractures in outcrops of the Utica Shale have not been studied in the context of mechanical stratigraphy. The composition, sedimentary texture, strength, and thickness of individual beds within the Flat Creek Shale and Dolgeville Formation are studied to better understand the nature of fracture propagation in thinlybedded mudrocks. The Flat Creek Shale and Dolgeville Formation are finegrained clastic rocks containing varying amounts of detrital carbonate grains. There are also multiple bentonite layers within both members. A fracture bedding termination analysis is conducted at three outcrops of the Flat Creek Shale to identify mechanical interfaces in the vertical section. A Schmidt Hammer is used to measure rock strengths approximately every . 2 vertical meters, and samples are collected throughout the section to be analyzed with XRD. Utica Core 74 NY-05 is described in terms of bedding thicknesses, lithofacies, and sedimentary texture. Three thin sections are analyzed with multiple petrographic microscopes to identify common textures and mechanical flaws associated with individual lithofacies. The combination of the fracture bedding termination analysis, rock strength measurement, core description, petrographic investigation, and XRD analysis assist with characterizing the mechanical behavior of these rocks. The fracture bedding termination analysis indicates that bentonites are responsible for approximately $51 \%$ of identifiable fracture terminations in the Flat Creek Shale; therefore bentonites act as mechanical barriers to fracture propagation. The bentonites exhibit significantly lower present day rock strength values and are primarily composed of clay minerals. While the remaining $49 \%$ of vein-filled fracture terminations occur in shale layers, there are few shale mechanical interfaces identified. The observation that bentonite horizons form significant mechanical barriers to fracture propagation has important implications for modeling subsurface fracture networks, because bentonites are widespread in basins, and are easily distinguished on gamma ray logs. 


\section{Acknowledgements}

I am a dwarf standing on the shoulders of giants. This project would still be in its infancy if it weren't for the guidance I've received from faculty, my committee, my peers, and a lot of intelligent and helpful people. I would first like to thank my advisor Dr. Shackleton for providing funding, direction, and an overall pleasant experience throughout this process. I'd also like to thank the rest of my committee, Dr. Carr and Dr. Benison, for offering their expertise and valuable advice. Your input, especially during my thesis proposal, has helped me to focus on the subjects that are most pertinent to my study.

There are quite a few people who have gone out of their way to help me with this project: Jim Leone, Aaron Evelsizor, Matt Erenpreiss, Dr. Carlton Brett, Dr. Bob Jacobi, Frank Karmanocky, and Lucas Hinegardner. Jim Leone, I can't thank you enough for giving Dr. Shackleton and I a tour, for getting me set up with Utica Core 74NY-05, and for introducing all of the literature and geologic concepts related to the Utica Shale. We would literally have gotten stuck up the wrong creek without your help. Speaking of Utica Core 74NY-05, I owe thanks to Aaron Evelsizor and Matt Erenpreiss. Thank you for being so flexible with your schedules, for willingly assisting me whenever I requested something, and for preparing the core every session. I hope all is going well at the survey. Dr. Brett, I may not have ended up working in the Cincinnati arch, but at the very least I now know a lot of really good fossil hunting localities! Thanks! Dr. Jacobi, thank you for all of your help, and I'm sorry Dr. Shackleton and I never got to stop by Buffalo. Frank, thanks for your help with the thin section photography. Lucas, I wouldn't have had the time to finish my thesis this semester had you not shown the initiative to help me and Dr. Shackleton with this research. I wish you the best of luck with grad school or wherever you end up working.

I'd also like to thank Dr. Brian Currie for many things, of which there are too many to list. Mom and Dad, thank you for letting me play in the gravel driveway. Kari, thank you for listening to me talk about my thesis every day for the past year or so.

Lastly, I'd like to thank Dr. Ding and the WVU Shared Research Facilities for providing training and access to XRD. 


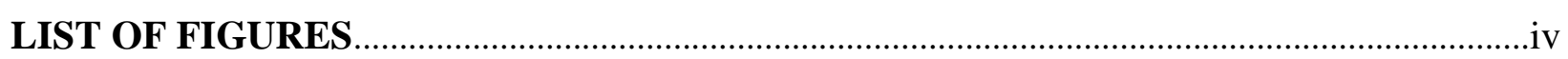

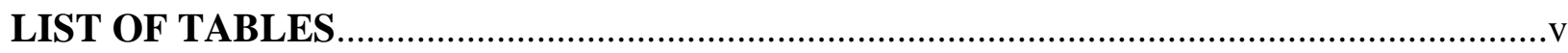



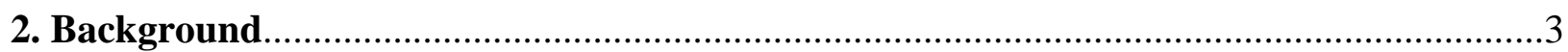

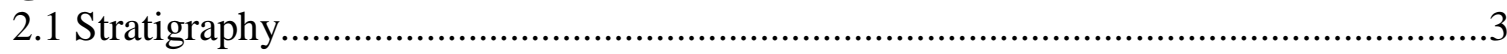

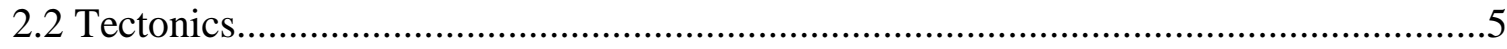



2.4 Burial Depth Estimation \& Vein-Fill Origin Theories..........................................13

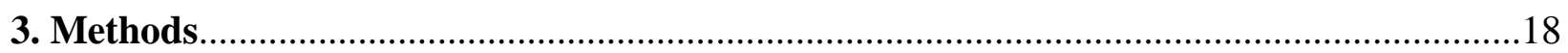



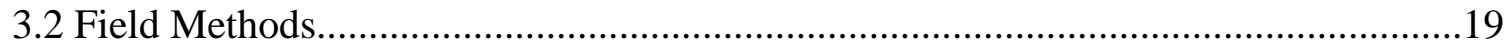

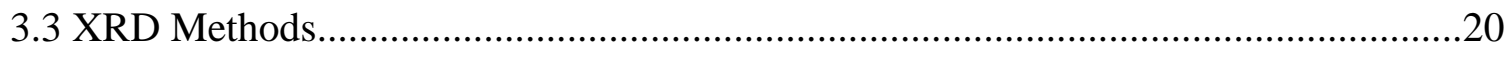

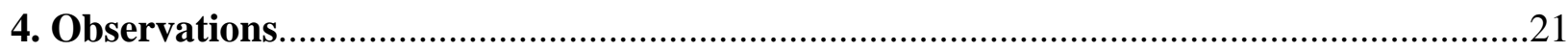

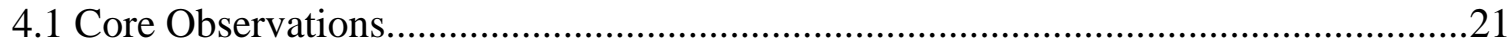

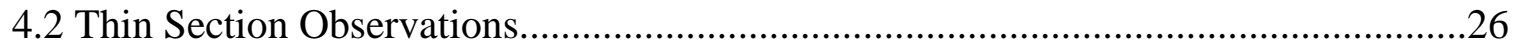

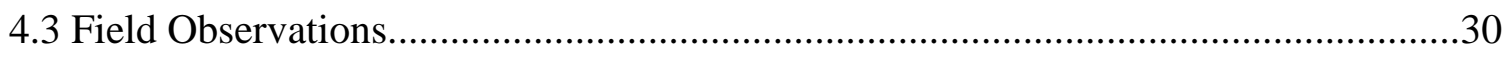

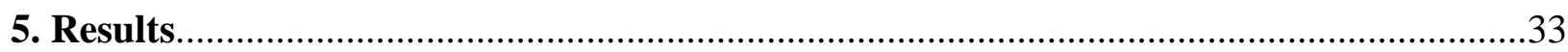

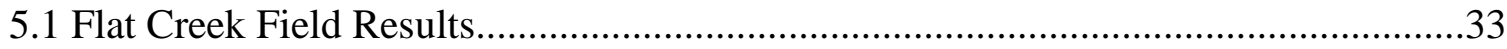

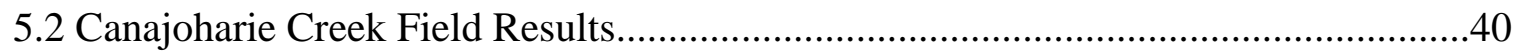

5.3 Fracture Bedding Termination Analysis............................................................. 43

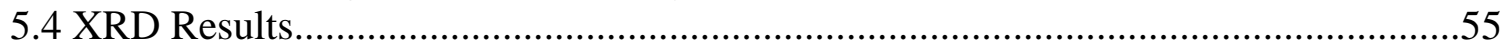

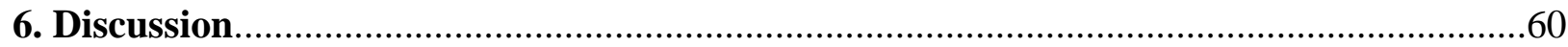

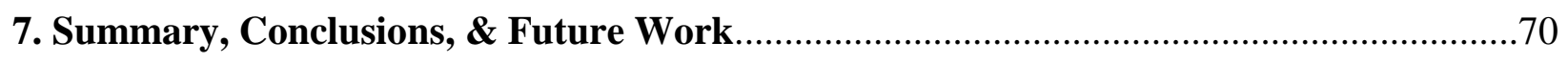



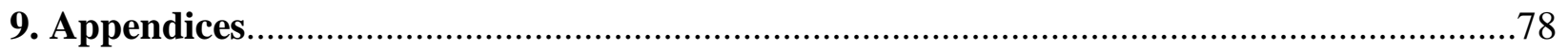

9.1 Appendix A: Core Description...................................................................... 78

9.2 Appendix B: Joint Orientations \& Spacing Data............................................... 100

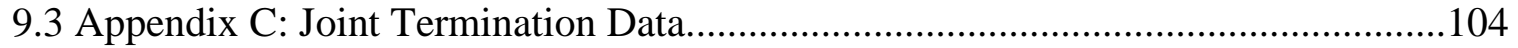



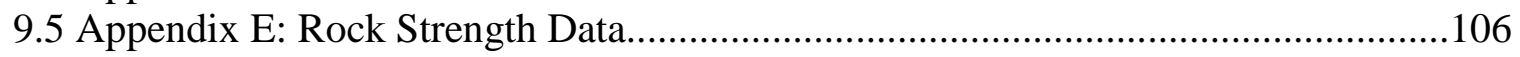

9.6 Appendix F: Terminations vs. Rock Strength Data........................................... 107

9.7 Appendix G: Lithostatic stress and hydrostatic pressure estimation........................110

9.8 Appendix H: Utica Core 74 NY-05 description by Gordon Baird..........................111 


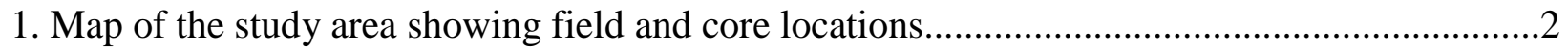

2. Ordovician Stratigraphic Column of New York State.........................................................

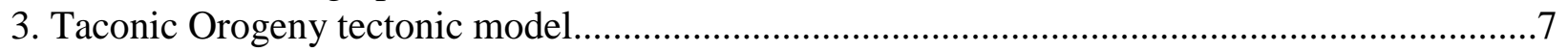



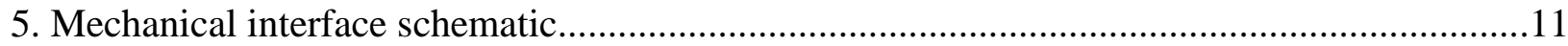

6. Utica vein fluid inclusion homogenization graph............................................................14

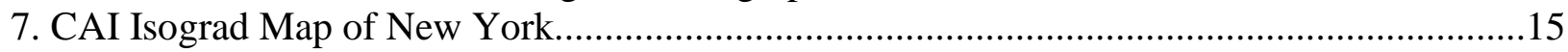

8. Utica Shale Burial Depth Map.............................................................................................16

9. Utica Core 74 NY-05 Stratigraphic Column......................................................................23

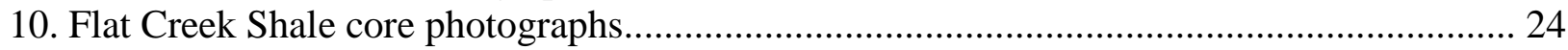

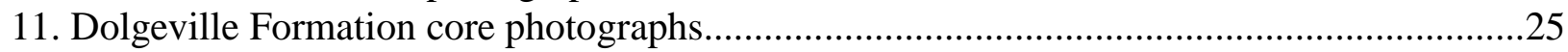

12. Thin section photographs of the three lithofacies at $0.63 \mathrm{x}$ and $1.6 \mathrm{x}$ magnification................26

13. Organic-rich shale lithofacies thin section photographs at $10 \mathrm{x} 2 \mathrm{x}$ magnification......................28

14. Calcilutite lithofacies thin section photographs at 10x2x magnification.................................29

15. Calcisiltite lithofacies thin section photographs at 10x $2 \mathrm{x}$ magnification..................................30

16. Photographs of the thick marker bentonite in Utica Core 74NY-05 and outcrop.....................31

17. Lower Flat Creek Section photograph..................................................................................

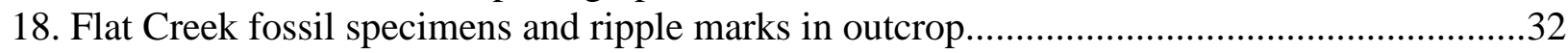

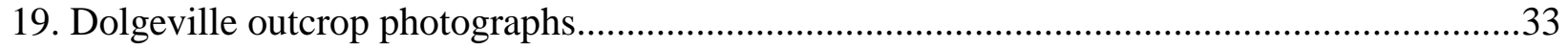

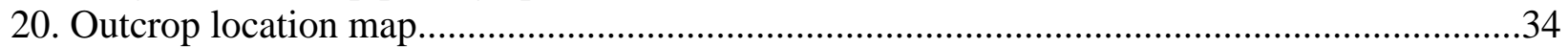

21. Lower Flat Creek section digital scan lines.........................................................................36

22. Mid Flat Creek section digital scan line............................................................................

23. Upper Flat Creek section digital scan line.........................................................................38

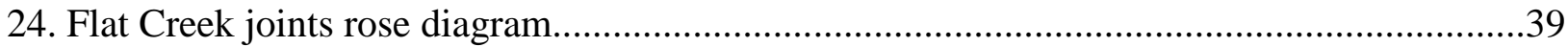

25. Dolgeville outcrop photograph illustrating relationship between bedding thickness and

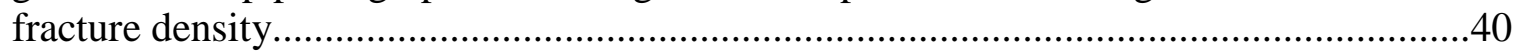

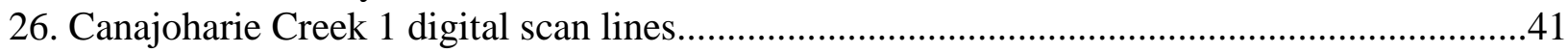

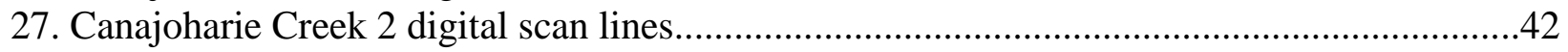

28. Canajoharie Creek joints rose diagram...........................................................................4

29. Lower Flat Creek section joint termination locations bar graph...............................................4

30. Mid Flat Creek section joint termination locations bar graph..................................................44

31. Upper Flat Creek section joint termination locations bar graph.............................................45

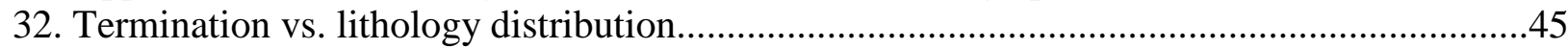

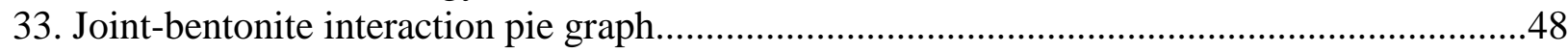

34. Joint termination, cross-cut, and step-over schematic..........................................................49

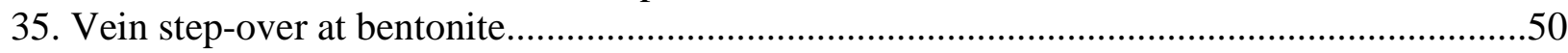

36. Rock strength and terminations \& step-overs vertical profiles................................................51

37. Lower Flat Creek photograph with overlay of rock strength and terminations \&



38. Mid Flat Creek photograph with overlay of rock strength and terminations \& step-overs vertical profile................................................................................................52

39. Upper Flat Creek photograph with overlay of rock strength and terminations \& step-overs vertical profile.............................................................................................53

40. Total rock strength Q-value distribution bar graph...............................................................54 
41. Shale and bentonite diffractograms of Flat Creek samples............................................55

42. Shale diffractograms of Flat Creek samples..............................................................55



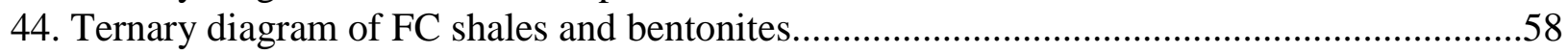

45. Glodes Road Discovery Field Cross-Section...........................................................61

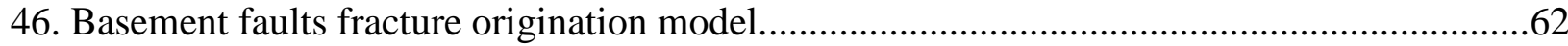



48. Mineral-filled rhombochasm photograph................................................................66

49. Photograph of layer-parallel fracture in the Dolgeville Formation...................................67

List of Tables

PAGE

1. CAI estimated burial temperature and depth................................................................. 16

2. Fluid inclusion homogenization burial temperature and depth......................................... 17

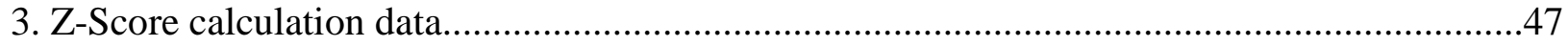

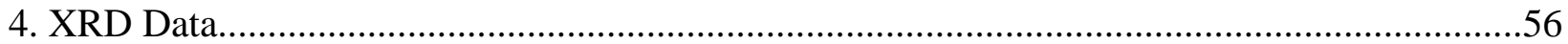

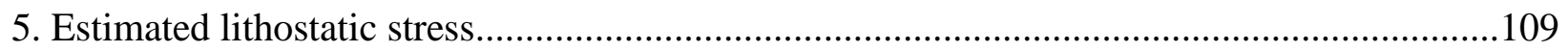






\section{Introduction}

Oil and gas production from horizontal wells in fine-grained clastic sedimentary rock plays is partially constrained by natural fractures and the extent of hydraulic fracturing-induced fracture networks. The orientation, morphology, density, and degree of connectivity of natural fractures influence the migration of hydrocarbons through a reservoir and into a wellbore. Natural fracture density within discrete rock beds is often a function of structural history, mechanical properties, fluid and diagenetic history, and bedding thickness. This study incorporates data and observations from outcrops and core of the Flat Creek and Dolgeville members of the Utica Shale in eastern New York State to characterize fracture propagation within thinly-bedded fine-grained sedimentary rocks. The New York State survey has provided access to Utica Core 74 NY-05 to be described for this project. Utica Core 74 NY-05 was collected from Montgomery County in eastern New York State and includes the same stratigraphic section seen in the field area (Figure 1).

This project assesses the mechanical and fracture stratigraphy of the Utica Shale by studying the factors that influence open mode fracture (joint) propagation. Mechanical stratigraphy is the subdivision of rock units based upon the mechanical behavior of individual bedded horizons and the interfaces between those horizons. Fracture stratigraphy is the characterization of rock units based upon natural fracture terminations and fracture spacing (fracture density) within individual bedded horizons. Fracture stratigraphy is influenced by mechanical stratigraphy, but the present day mechanical properties of rocks may not always coincide with those that were present at the time of initial fracture propagation (Shackleton et al. 2005). The relationship between mechanical properties and fracture propagation in the Utica Shale is characterized by investigating bedding thickness, composition, and rock strength. The 
term unit thickness is occasionally more appropriate than the term bedding thickness, because multiple beds and/or laminae may act as one cohesive mechanical entity (Narr \& Suppe 1991). Local structural features are identified to recognize potential aberrations in the fracture stratigraphy. Diagenetic history is studied to understand how the mechanical properties of these rocks may have changed through time. The results of this project assist with characterizing subsurface fracture stratigraphy in mudrock plays based upon parameters that can be acquired with wireline logs.



Figure 1: Location map of the study area near Canajoharie, NY. This location is part of the greater Mohawk Valley in eastern New York State. Fieldwork is conducted on two creeks: Canajoharie Creek and Flat Creek. These two field sites are approximately 1.5 miles apart. 


\section{Background}

\subsection{Stratigraphy}

The Utica Shale of eastern New York State is comprised of three stratigraphic units, including the Flat Creek Shale, the Dolgeville Formation, and the Indian Castle Shale. This study focusses on the lowermost, organic-rich members of this formation: the Flat Creek Shale and the Dolgeville Formation. These members are relatively well preserved in outcrops along Canajoharie Creek in Wintergreen Park and along Flat Creek near Canajoharie, NY. The Flat Creek Shale is composed of graptolite-bearing, calcareous, laminated, black shales that grade upwards into calcilutites (Joy et al. 2000). The Dolgeville Formation consists of interbedded dark gray shale and calcisiltitic limestone (Baird \& Brett 2002). Calcilutites and calcisiltites are mixed siliciclastic and carbonate rocks defined by the percent composition of detrital carbonate. A calcilutite consists of greater than $50 \%$ detrital carbonate grains, and a calcisiltite is predominantly composed of silt-sized detrital carbonate grains. The mechanical behavior of the Flat Creek Shale and the Dolgeville Formation may be different due to variability in the abundance of detrital carbonate grains in each formation. Shale that is rich in organic-content is chosen for study in this project because subsurface mudrock targets also exhibit this property.

Shale is deposited in a variety of depositional environments. Previous studies agree that the Utica Shale was deposited in a foreland basin, but the specific paleobathymetry and basin setting are debated. Recent work suggests that some organic-rich mudrocks likely formed under relatively swift current conditions (Schieber et al. 2007). Schieber \& Schimmelmann (2010) postulate that lenticular lamination in shales forms by clay floccule aggregation during migration in a current, followed by compaction after deposition. The Utica Shale may have been deposited in relatively swift flow conditions as evidenced by the presence of wavy lamination, small scale 
trough cross-stratification, and soft sediment deformation in Utica Core 74 NY-05. Smith et al. (2013) suggest that organic-rich mudrock intervals are deposited in water depths of 50m or less. According to Smith's model, the organic-rich mudrocks of the Utica Shale would have been deposited on the craton-side of the Taconic foreland basin in a seasonably oxygen-rich water column.



Figure 2: Stratigraphic column of the study interval. The Flat Creek Shale is correlative with the Denley Limestone to the west and the Dolgeville Formation is correlative with the Rust and Steuben Limestone to the west. Modified from Joy et al. 2004.

Previous studies have utilized K-bentonites, graptolites, conodont and chitinozoan range data, and extensive event beds to establish a sequence stratigraphic framework in this region (Baird \& Brett 2002; Joy et al. 2000). Joy et al. (2000) designated four third-order sequences within stratigraphic sections of the Mohawk Valley, New York. The Flat Creek Shale is interpreted to have been deposited during the highstand systems tract of sequence 3 , while the Dolgeville Formation is interpreted to have been deposited during the transgressive systems tract 
of sequence 4 (Joy et al. 2000). In general, the siliciclastic deposits within this region display a broad and drastic thickening to the east, whereas carbonates display a general thinning from west to east (Joy et al. 2000). The Dolgeville Formation is chronostratigraphically correlative with the Upper Trenton group further to the west (Baird \& Brett 2002; Joy et al. 2000), and the Flat Creek Shale likely correlates with the Denley Limestone to the west (Figure 2; Joy et al. 2000).

\subsection{Tectonics}

The Utica Shale was deposited during the Ordovician Taconic Orogeny. The Taconic Orogeny persisted diachronously along the length of the Appalachians, progressing from the present day southwest to northeast, between approximately $495 \mathrm{Ma}$ and $432 \mathrm{Ma}$ (Wise \& Ganis 2009; Ettensohn 1991). This period of time records the initial closing of the Iapetus Ocean and the onset of a series of collisional events between an arc complex and the Laurentian Craton passive margin (Cisne et al. 1982; Ettensohn 2004). A foreland basin was produced by the lithospheric response to overthrusting of an accretionary prism onto the Laurentian Craton. The lithosphere adjacent to the increased supracrustal load experienced flexural subsidence and normal faulting (Figure 3; Cisne et al. 1982; Bradley and Kidd 1991; Baird \& Brett 2002). Total subsidence in the foreland basin varies by location because of localized intense tectonism along the paleo-active margin, which is manifested by the deposition of organic-rich shales in subbasins with increased accommodation (Dewey \& Kidd 1974; Ettensohn 1991). The presence of sub-basins and faults that terminate in the Utica Shale suggest syndepositional deformation in the basin (Smith 2006).

Since deposition during the Taconic Orogeny, there have been multiple periods of increased tectonic activity that have significantly influenced the burial history of these rocks, 
including the Salinic, Acadian, and Alleghanian orogenies. Sedimentation associated with the Salinic and Acadian orogenies resulted in the deep burial of the Utica Shale; whereas exhumation associated with the Alleghanian Orogeny is responsible for these rocks being exposed at the surface today. The Silurian Salinic Disturbance is interpreted to have consisted of at least two tectophases, and produced two corresponding clastic wedges (Ettensohn 2004). The Devonian through Early Mississippian Acadian Orogeny consisted of multiple tectophases that lead to the deposition of thousands of feet of open-marine, marginal-marine, and terrestrial facies (Ettensohn 2004). The Utica Shale of eastern New York State may have been buried to depths greater than 10,000 feet by the end of the Acadian Orogeny (Smith 2013). The tectonic collision between Laurentia and Gondwana is known as the Alleghanian Orogeny, and is interpreted to have initiated in the Early Pennsylvanian (Ettensohn, 1994). This collision involved transpression, suturing, and exhumation of the rocks outcropping in eastern New York State (Lash \& Engelder 2007).

The field area of this study, near Canajoharie, NY, resides in the greater Mohawk Valley of New York State. Fractures in Mohawk Valley rocks have been studied extensively by Jacobi (2002), Agle (2008), Cross (2004), and additional members of the University at Buffalo Rock Fracture Group (UBRFG; Figure 4). Faults in the Mohawk Valley are interpreted to have initiated during the Taconic Orogeny as thrust-loading induced the reactivation of primarily NNE-trending extensional faults (Jacobi 2002). Differential subsidence associated with these faults has been interpreted to be responsible for abrupt lateral facies changes in this region (Bradley \& Kidd; Cisne 1982). In eastern New York State, Cross (2004) identified 5 primary open-mode vein-filled fracture sets to the east of Little Falls, NY, including NE, E, WNW, and NW (the NW set consists of vein-filled and unfilled fractures) sets (Cross 2004 via Agle 2008). 
Most vein-filled joints in outcrops along Canajoharie Creek and Flat Creek strike nearly E-W at $280^{\circ}$.

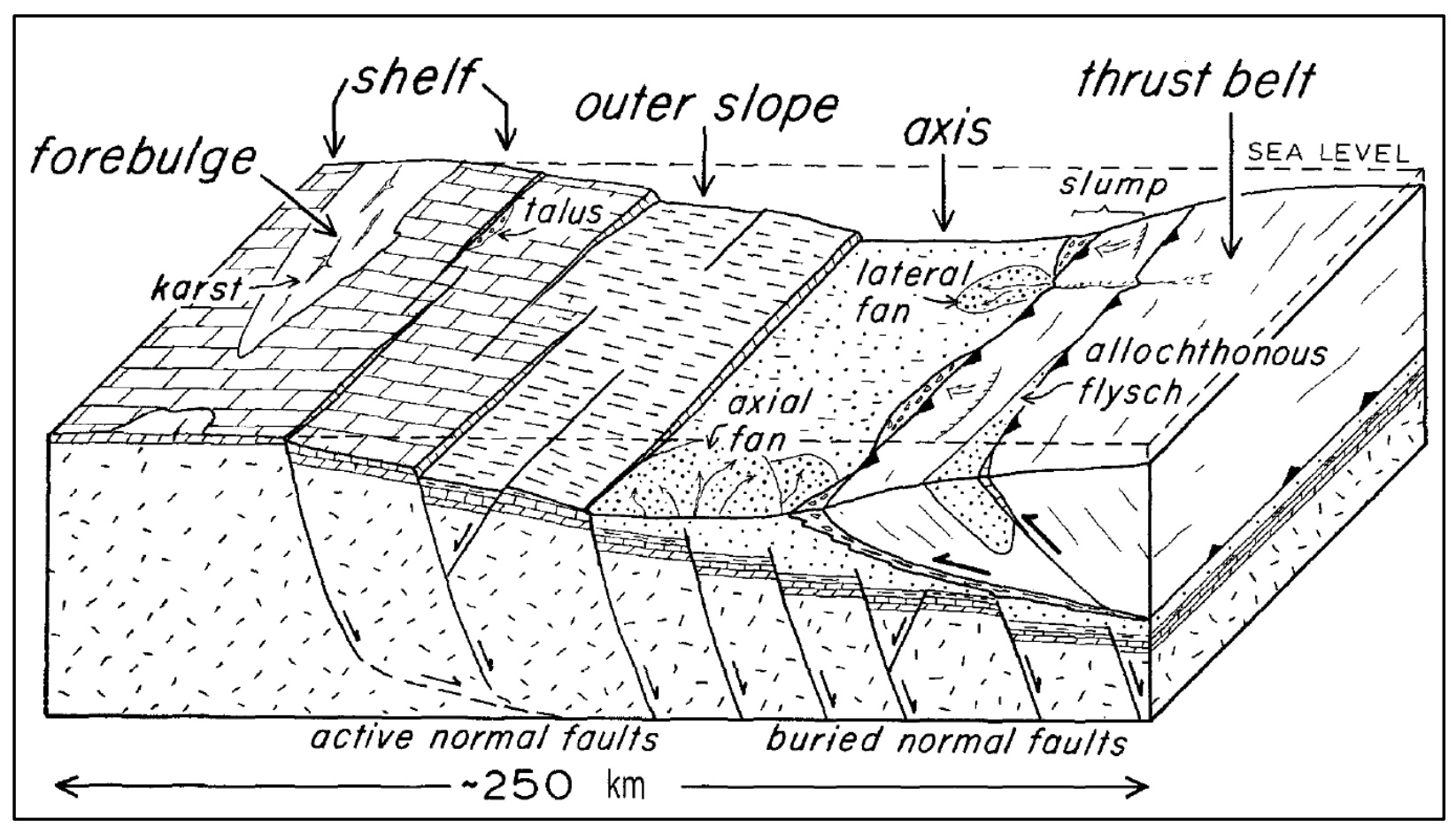

Figure 3: Plate Tectonic model of the Taconic Orogeny. Carbonate platform to the west and the source area of terrigenous clastics to the east. Deposition of Utica Shale sediments likely occurred on the craton-side slope of the foreland basin, where terrigenous clastic dilution was minimal. Modified from Bradley \& Kidd 1991.

\subsection{Rock Mechanics}

There has been limited investigation of mechanical properties, and their relation to fracture stratigraphy, in the Utica Shale, despite there being multiple studies about fractures in rocks throughout New York State (Jacobi 2002; Agle 2008). Previous studies of mechanical stratigraphy have identified a relationship between bedding thickness, rock composition, rock strength, and fracture propagation in other mixed fine-grained siliciclastic and carbonate formations (Morris et al 2009; Lezin et al. 2009; Rijken \& Cooke 2001), but such relationships in 
low porosity/permeability unconventional petroleum reservoirs remain poorly understood. Vertical boreholes are less likely to intersect with near-vertical fractures, leading to inaccurate representations of fracture density in the subsurface (Laubach et al. 2009). Additionally, the coarse resolution of sub-seismic fracture data poorly characterizes fracture stratigraphy. This study benefits the current understanding of the relationship between mechanical stratigraphy and fracture stratigraphy in mudrock plays, by studying an outcrop analog of a fine-grained, mixed siliciclastic and carbonate hydrocarbon reservoir.



Figure 4: Fracture map of NY State with Landsat-identified lineaments. The red star represents the field location of this study. Modified from Jacobi, 2002.

Open-mode fracture propagation in rocks is controlled by stress and mechanical properties. Joints initiate at macroscopic and microscopic mechanical flaws within a rock unit, 
because stress is concentrated at these locations (Pollard \& Aydin 1988). A flaw is any heterogeneity within a rock unit, and includes features like microfractures, fossils, sedimentary textures, or grains of varying size. Stress concentration is greater in macroscopic flaws than it is in microscopic flaws (Rijken \& Cooke 2001). In formations with heterogeneous lamina or bedding, fractures generally initiate in brittle layers and terminate at the contact with ductile layers (Underwood et al. 2003). In homogenous formations, fracture tip propagation is directed by the connectivity of flaw-induced microcracks (Pollard \& Aydin 1988). When the stress at a flaw tip exceeds the tensile strength of a rock unit, a joint propagates (Rijken \& Cooke 2001). Lithologic units with greater rock stiffness and higher pore fluid pressures are more prone to forming joints (Lezin et al. 2009; Rijken \& Cooke 2001). Several studies have explored fracture propagation in shales and carbonates (Laubach et al. 2009; Lezin et al. 2009; Rijken \& Cooke 2001). The thicknesses of the detrital carbonate beds in the Utica Shale are much less than those observed in the studies by Rijken \& Cooke (2001), Lezin et al. (2009), and Laubach et al. 2009, making the properties of the rocks in this study unique.

Morris et al. (2009) utilized a Schmidt hammer to measure the stiffness and stiffness contrast of Cretaceous carbonate strata to better understand relationships between mechanical properties and fracture propagation. Underwood et al. (2003) mapped the extent of openingmode natural fractures in relatively undeformed dolomite to study relationships between mechanical stratigraphy, lithostratigraphy, and fracture termination. The conclusions drawn from these studies are used to interpret rock strength and fracture termination data from the Utica Shale.

The rock strength of individual rock beds in the field can be evaluated in-situ using a Schmidt hammer. A Schmidt hammer measures the rebound of a hammer impacting a rock, 
thereby providing a relative, but widely applicable means of estimating rock hardness (Aydin \& Basu 2005; Morris et al. 2009; Underwood et al. 2003). The Schmidt Hammer rebound values of a lithologic unit record rock stiffness, which is the ability of a rock to withstand deformational change. Rock units with greater stiffness ought to exhibit greater fracture densities, given that other mechanical and stress conditions are identical.

Individual beds in an outcrop section are distinguished by an abrupt or gradational change in lithology, sedimentary structures, or fossil content. The properties that differentiate an individual bed may also be responsible for changes in stiffness or stiffness contrast (Morris et al. 2009). Ductile layers act as a buffer to accommodate strain, thus impeding fracture propagation, while stiff layers promote fracture propagation (Morris et al. 2009). A propagating fracture will transect, terminate, or step-over at the interface between two units of varying stiffness (Cooke \& Underwood 2000). Fracture termination and step-over is also influenced by the strength of bonding and the orientation of stress at a mechanical interface (Cooke \& Underwood 2000; Figure 5). A mechanical interface is the bounding stratigraphic horizon at which a natural fracture terminates (Underwood et al. 2003). There are two end-member modes of behavior at mechanical interfaces: sliding and opening. A sliding interface promotes fracture propagation, whereas an opening interface promotes step-over (Cooke \& Underwood 2000). Fractures terminate when stress is insufficient to overcome the tensile strength of the rock unit on the opposite side of the interface. Rock units are considered a mechanical interface when a small percentage of fractures propagate through the horizon (Underwood et al. 2003). 


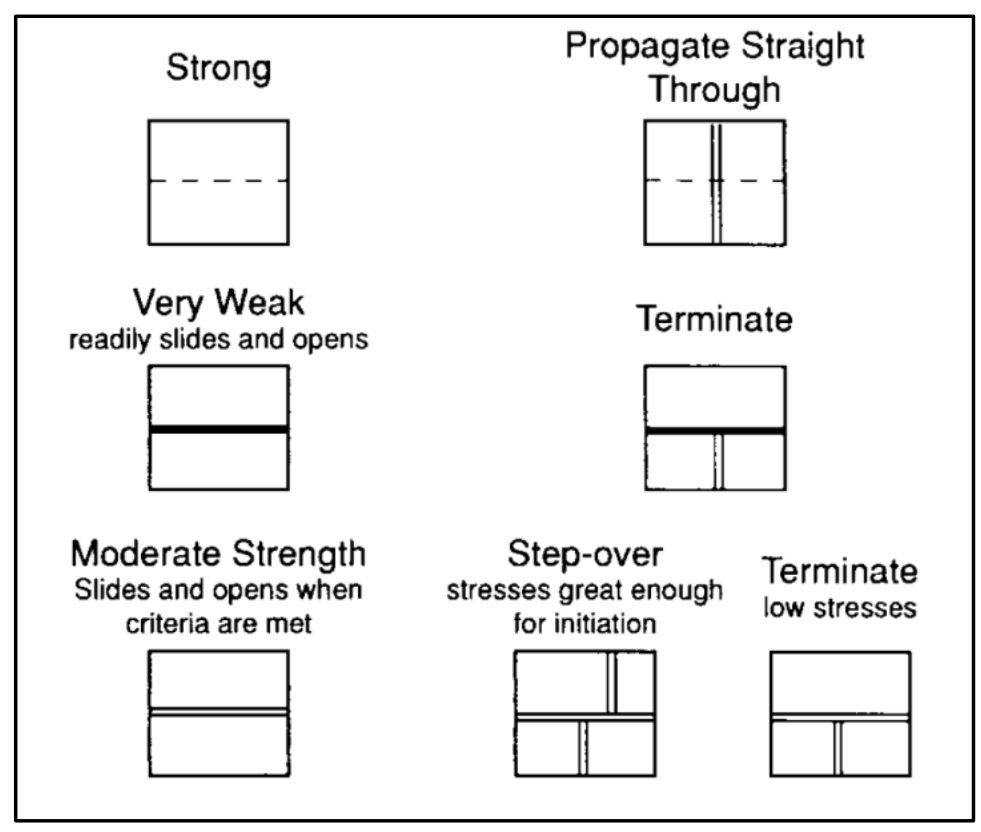

Figure 5: Mechanical interface bonding strength controls on joint propagation. A strong bond between the mechanical layer and the adjacent strata promotes cross-cutting. A very weak bond inhibits fracture propagation. Moderate strength bonding promotes step-over and termination. Modified from Cooke \& Underwood 2000.

Fracture density is also a function of the thickness of discrete rock beds (Narr \& Suppe 1991). Narr \& Suppe (1991) studied jointing in outcrops of the Monterey Formation in the Santa Maria basin and Santa Ynez Mountains of California to develop a modified Hobbs' bed thickness to joint spacing model that incorporates the effect of flaws. A relationship between bedding thickness and fracture density exists because a zone of decreased stress develops around a newly formed fracture (Narr \& Suppe 1991). This "stress shadow" is approximately proportional to the height of the fracture; therefore the bedding thickness to joint spacing ratio in a fracture-saturated bed is ideally near 1 (Bai \& Pollard 2000; Narr \& Suppe 1991). Rock beds with greater thickness exhibit lower joint densities, and rock beds with lesser thickness exhibit greater joint densities.

Petrographic analysis of thin sections from Utica Core 74 NY-05 is modeled after the methods of Lezin et al. (2009) and Palchik \& Hatzor (2002). In both studies the authors utilized petrographic observations to qualitatively assess rock strength in calcareous rocks. Lezin et al. (2009) studied the relationship between petrographic and petrophysical parameters and joint 
density in Kimmeridgian limestone of the Chay Peninsula, western France. Their findings suggest a link between rock strength, Young's modulus, and sparite/micrite ratios (Lezin et al. 2009). The sparite/micrite ratio in Kimmeridgian carbonates reflects the average state of crystallinity, which is interpreted to influence rock strength (Lezin et al. 2009). The authors also posit that an increase in the amount of $\mathrm{CaCO}_{3}$ cement and/or a decrease in porosity increases rock elasticity (Lezin et al. 2009). The Utica Shale is a fine-grained detrital carbonate-rich clastic rock with limited recrystallization and cementation; therefore the sparite/micrite relationship is not applicable, but this study illustrates how diagenetic history can influence mechanical properties.

Palchik \& Hatzor (2002) developed an empirical model to predict the onset of open-mode fracturing using porosity and rock elasticity data from dolomite and limestone samples. The authors interpreted that rock stiffness is influenced by the length of grain to grain contacts and by the number of contacts per grain. The results of this study suggest that sedimentary petrography is one method for making a qualitative assessment of relative rock stiffness, based upon pore types, grain size, matrix composition, and sedimentary texture. Differences in grain size, grain composition, and sedimentary texture between individual beds in the Utica Shale may also contribute to changes in rock stiffness. Intergranular porosity is absent in samples of the Utica Shale, but there is likely variable porosity associated with the relative abundance of organic material.

Fracture stratigraphy may not always coincide with lithostratigraphy or mechanical stratigraphy (Laubach et al 2009). Diagenetic processes may alter the mechanical properties of rocks after initial joint propagation, thus skewing present-day mechanical stratigraphy (Shackleton et al. 2005). X-ray diffraction and petrographic analysis are performed on samples 
of the Utica Shale to understand the influence of diagenesis. The timing of diagenetic alteration in the Utica Shale is equivocal, but the characterization of fracture stratigraphy provides a proxy for mechanical stratigraphy at the time of fracture propagation that is independent of present day rock strength.

\subsection{Burial Depth Estimation \& Vein-Fill Origin Theories}

Studying natural fractures in mudrock reservoirs can be difficult due to the limitations of subsurface data; therefore outcrop studies are necessary to assist with characterizing fracture properties. However, the fractures present at the surface today must have formed at significant depth in order for surface observations to have an application to subsurface fracture characterization. The specific timing of fracturing in the Utica Shale of eastern New York State is unclear. Conodont alteration index (CAI) and fluid inclusion homogenization data can both be interpreted to suggest that some of the vein-filled fracture sets initiated in the subsurface at depths greater than $3 \mathrm{~km}(\sim 10,000 \mathrm{ft}$.$) , but others have suggested that these fractures formed in$ the shallow subsurface during the Taconic Orogeny (Jacobi 2010; Smith 2006). The interpretations that these joints are Taconic-aged are contingent upon the vein-fill having a hydrothermal origin.

Agle (2008) observed a dominant WNW fracture set in Utica Shale strata to the west of Canajoharie in the Little Falls, NY region. Agle (2008) concluded that this fracture set is likely the result of compression associated with continental collision, but did not offer an interpretation of the timing of this collision. However, Jacobi (2010) suggests that The WNW and E-W joint sets formed in the shallow subsurface during the Late Taconic Orogeny. Jacobi (2010) posits that these joint sets developed as the result of transpression and lockup during collision between 
Laurentia and the converging volcanic arc. The fractures near Little Falls exhibit calcite vein fills, which host fluid inclusions. These inclusions were studied for homogenization temperatures (Figure 6). The results suggest that the calcite veins precipitated in a temperature range between $\sim 100^{\circ} \mathrm{C}$ and $\sim 140{ }^{\circ} \mathrm{C}$.

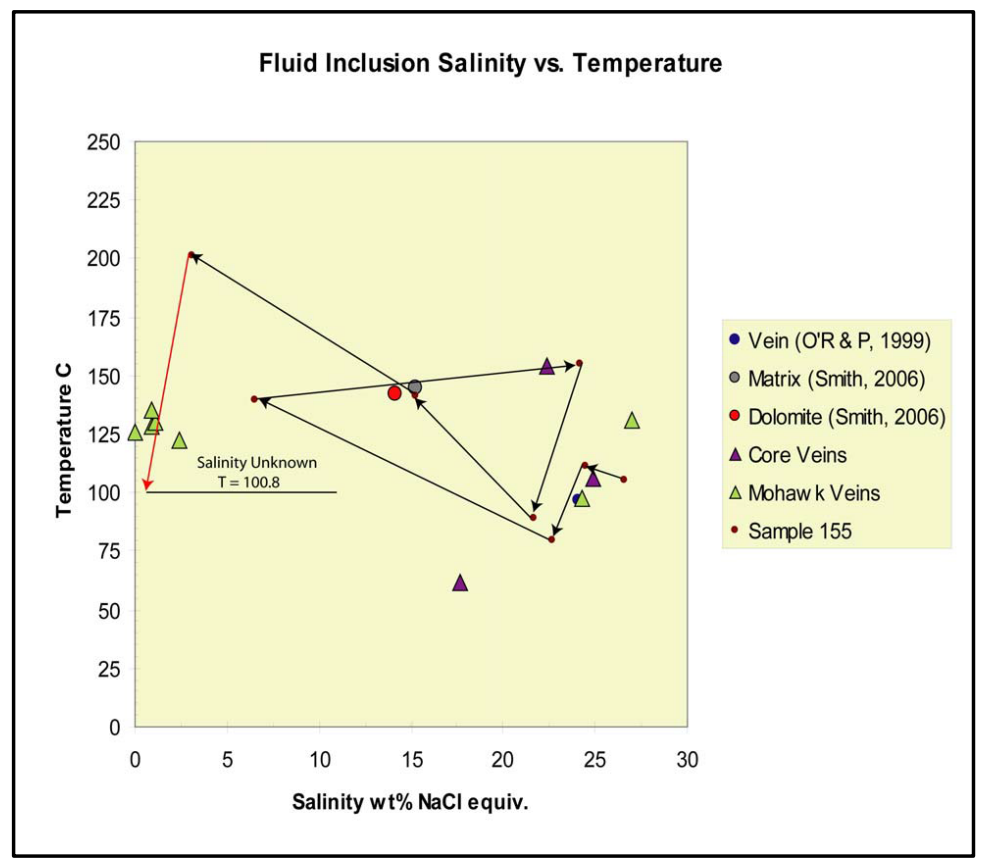

Figure 6: Homogenization temperatures of fluid inclusions in veins in the Utica Shale. The Mohawk veins are considered the most comparable to the veins in this study. Modified from Agle 2008.

Conodont alteration index data provides an additional burial temperature proxy separate from the temperature range derived by Agle (2008). Conodonts are microscopic hard parts of extinct chordates that range in size between $.1 \mathrm{~mm}$ and $1 \mathrm{~mm}$ (Epstein \& Epstein 1977). Conodonts are interpreted to have had global inhabitance in marine settings from the Cambrian through most of the Triassic (Epstein \& Epstein 1977). The color of conodonts changes from a light reddish-tan to nearly black during burial and thermal maturation. The degree of color alteration in conodonts has been linked to specific temperature regimes (Epstein \& Epstein 1977). Repetski et al. (2008) have recently produced an updated CAI isograd map of the 
Appalachian Basin. CAI values from the Trenton Limestone are used to approximate the thermal maturity of the overlying Utica Shale. The CAI values near the study area in eastern New York State are between 3 and 4 (Figure 7; Repetski et al. 2008). According to Epstein, CAI values ranging between 3 and 4 suggest burial temperatures between $120^{\circ} \mathrm{C}$ and $200^{\circ} \mathrm{C}$. While this is range is broad, this proxy for burial temperature coincides with the values observed by Agle (2008).



Figure 7: CAI isograd map of New York. The Canajoharie outcrops are designated by the red star and are located between CAI values 3 and 4. Modified from Repetski et al. 2008.

Burial depths are extrapolated from the estimated burial temperatures by assuming a paleo-surface temperature and paleo-geothermal gradient. A surface temperature value is assigned $15^{\circ} \mathrm{C}$ based upon the global mean present-day surface temperature, and a geothermal gradient is assigned a range between $25^{\circ} \mathrm{C} / \mathrm{km}$ and $30^{\circ} \mathrm{C} / \mathrm{km}$ (NASA; Repetski et al. 2008; Schlumberger 2014). The geothermal gradient may be completely inaccurate due to localized hydrothermal activity. Depth is calculated by using the following equation: 


\section{Estimated Temperature $\left({ }^{\circ} \mathrm{C}\right)$-Surface Termperature $\left({ }^{\circ} \mathrm{C}\right)$ \\ Geothermal Gradient $\left({ }^{\circ} \mathrm{C}\right.$}

CAI estimated burial depths are shown in data table 1 and fluid inclusion estimated depths are shown in data table 2 . The fluid inclusion estimated depth provides a more narrow range, and suggests burial depths between $3 \mathrm{~km}$ and $5 \mathrm{~km}(\sim 10,000 \mathrm{ft} . \rightarrow \sim 16,000 \mathrm{ft})$. The resulting depth range is reasonable because the Utica Shale is $10,000 \mathrm{ft}$. in the subsurface of south-central New York (fig 8; Smith et al. 2013).

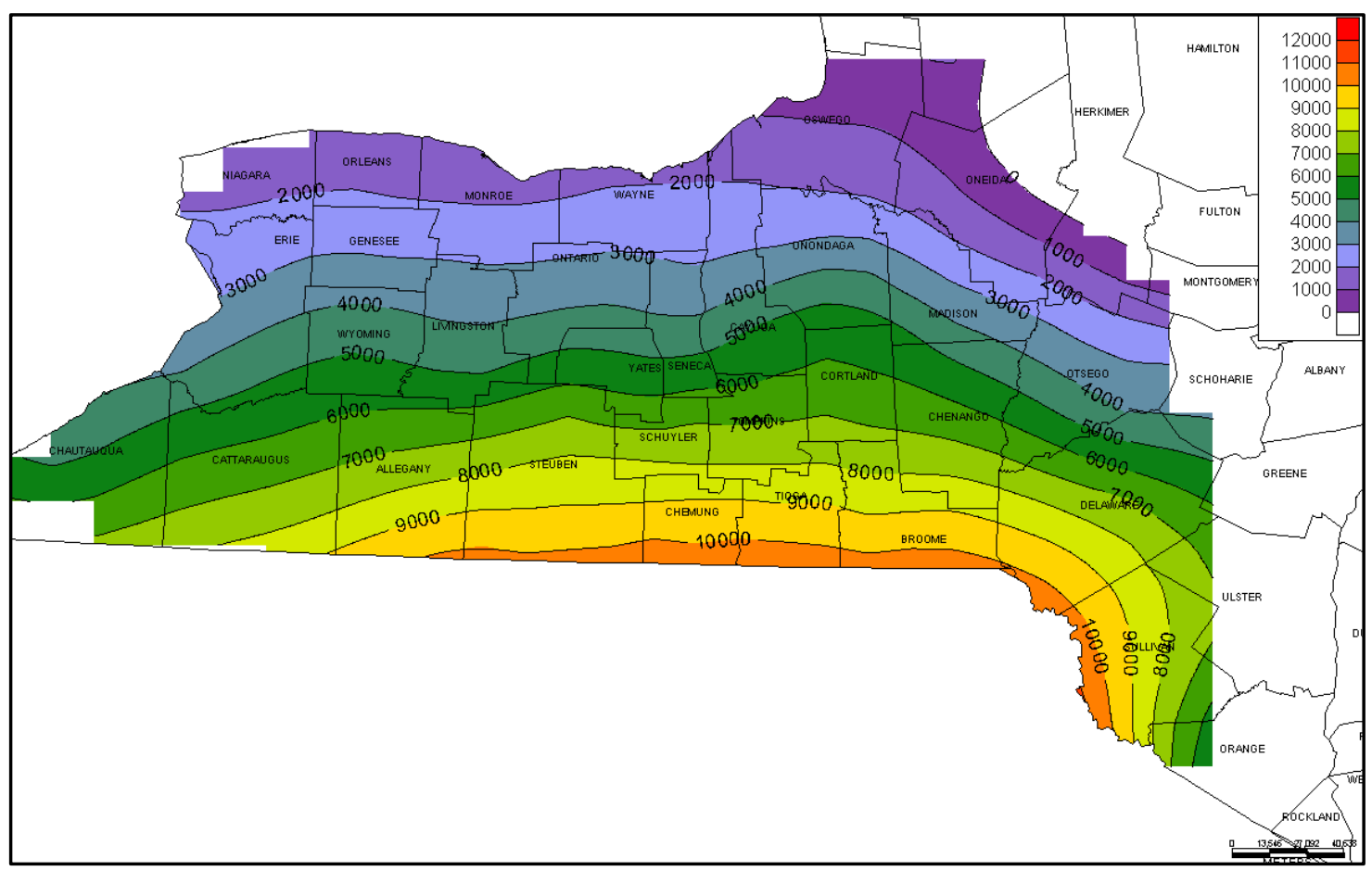

Figure 8: Burial depth to the top of the Utica Shale (or to the top of the Trenton Group where Utica facies are absent). Modified from Smith et al. 2013.

\begin{tabular}{|r|r|r|r|r|}
\hline Surface temperature $\left({ }^{\circ} \mathbf{C}\right)$ & Geothermal gradient $\left({ }^{\circ} \mathbf{C} / \mathbf{k m}\right)$ & CAI & CAI temperature $\left({ }^{\circ} \mathbf{C}\right)$ & Estimated depth $(\mathbf{k m})$ \\
\hline 15 & 25 & 3 & 110 & 3.8 \\
\hline 15 & 30 & 4 & 200 & 6.2 \\
\hline 15 & 25 & 4 & 200 & 7.4 \\
\hline 15 & 30 & 3 & 110 & 3.2 \\
\hline
\end{tabular}

Data Table 1: CAI estimated temperatures and depths. 


\begin{tabular}{|r|r|r|r|}
\hline Surface temperature $\left({ }^{\circ} \mathbf{C}\right)$ & Geothermal gradient $\left({ }^{\circ} \mathbf{C} / \mathbf{k m}\right)$ & Fluid inclusion homogenization $\left({ }^{\circ} \mathbf{C}\right)$ & Estimated depth $(\mathbf{k m})$ \\
\hline 15 & 25 & 100 & 3.4 \\
\hline 15 & 30 & 140 & 4.2 \\
\hline 15 & 25 & 140 & 5.0 \\
\hline 15 & 30 & 100 & 2.8 \\
\hline
\end{tabular}

Data Table 2: Fluid inclusion homogenization estimated temperature and depth.

The temperatures estimated from conodont alteration and fluid inclusion homogenization data can both be interpreted to suggest that the vein-filled fractures present in outcrops of the Utica Shale in eastern New York State formed in the deep subsurface at depths greater than 10,000 feet, however, the depths estimated by fluid inclusion homogenization temperatures may be influenced by hydrothermal activity. The fluid that precipitates vein-fill is unequivocally hydrothermal in origin if fluid inclusion homogenization temperatures are greater than CAI temperatures, but this is not the case for the Utica Shale (Smith 2006). The interpretations of hydrothermal-derived vein-fill are rendered inconclusive because the conodont alteration temperatures of the Utica Shale reach up to $200^{\circ} \mathrm{C}$, exceeding the fluid inclusion homogenization temperatures. There remains a possibility that the vein-filled fractures in this study are related basement structures and hydrothermal dolomite in the Trenton-Black River Formation. Seismic data from New York State shows faults that terminate within the Utica Shale, indicating that the basement faults were only active through the Late Ordovician Taconic Orogeny. Hydrothermal alteration is closely related to the timing of fault movement; therefore the dolomitized fractures formed in the shallow subsurface (<1100 ft.; Smith 2006). Smith (2006) provides a paragenetic sequence of the Trenton-Black River. The first phase of diagenesis consisted of shallow-burial calcite cementation and compaction. This was followed by matrix dolomitization, faulting, fracturing, brecciation, and then growth of saddle dolomite, quartz, authigenic feldspar, pyrite, bitumen, and lastly an additional calcite precipitation event. Agle (2008) also observed 
anthraxolite and liquid hydrocarbon inclusions in calcite veins. The bitumen phase likely developed after significant burial and hydrocarbon maturation. A systematic study of vein fill in fractures on Flat Creek and Canajoharie Creek would be necessary to rule out early development of the E-W fracture set during the Taconic Orogeny.

\section{Methods}

\subsection{Core Methods}

The Dolgeville Formation and Flat Creek Shale intervals of Utica Core 74 NY-05 are described to identify lithologies, sedimentary structures, and bedding thicknesses. A sponge saturated with distilled water is used to clean the surface of the core prior to each period of investigation. Utica Core 74 NY-05 is two inches in diameter and is cut in half vertically, exposing a flat surface. The core is correlated to outcrop sections by identifying one particularly thick bentonite, and by observing unique bedding characteristics in each formation. The thick bentonite is confidently correlated because it is directly below the Dolgeville Formation in both the outcrop and the core.

Three thin sections from Utica Core 74 NY-05 are analyzed with a Leica DM EP, an Olympus SZX10, and an Olympus BX53 petrographic microscope under plane polarized, cross polarized, reflected, and UV light at multiple magnifications. The following characteristics are identified in each sample: grain composition and abundance, grain size, fossil type and size, sphericity, and roundness, as well as diagenetic features and sedimentary textures. Samples are also investigated in terms of how specific features may influence the mechanical behavior of lithofacies. The three samples are collected from the following depths: 465, 473, and 477 feet. This interval includes the transition from the Flat Creek Shale upwards into the Dolgeville 
Formation. The lithologies of beds within the core are classified according to the system initially proposed by Grabau (1903). The samples are selected to be representative of three major lithofacies: organic-rich black shale (sample 1), calcilutites (sample 2), and calcisiltites (sample 3). The three thin sections are made by Spectrum Petrographics, and an alizarin red S reagent stain is applied to one side of the thin sections to assist with differentiating between detrital carbonate grains and other clasts.

\subsection{Field Methods}

A fracture-bedding termination analysis is conducted at three outcrops of the Flat Creek Shale on Flat Creek. The analysis utilizes photogrammetry, field measurements, and a rugged tablet PC to digitize fractures in the field. The fracture-bedding termination analysis is performed on near-vertical and sub-vertical outcrop faces to identify mechanical interfaces in the vertical sections. Photographs are taken perpendicular to each outcrop face approximately every 10 feet and are stitched together using the Agisoft PhotoScan software package. Individual highdefinition photographs are taken in areas where fracture density is high and fracture aperture is low. The individual photograph or the photogrammetized image is used as a backdrop for fracture digitization. A measuring tape is placed along the length of the outcrop and the orientation of the tape is recorded. Fracture traces are digitized on the image while the location along the scan line, vertical termination location, fracture fill, aperture, and strike and dip are recorded. The vertical extent of some fractures is difficult to define because outcrop faces are partially covered by vegetation, scree, and the creek surface. Fracture density is calculated as the number of joints per scan line divided by the length of the scan line in meters (Lezin et al. 2009). Density is only calculated with respect to the $\mathrm{E}-\mathrm{W}\left(280^{\circ}\right.$ strike $)$ vein-filled joint set. 
A Silver Schmidt Concrete Test Hammer type L is used to measure the rock strength of shale and bentonite layers in conjunction with the fracture bedding termination analysis, and samples are collected throughout the vertical section. Sampling of rock rebound follows the guidelines outlined by the International Society for Rock Mechanics (ISRM) suggested methods (Aydin 2009). Rock surfaces are flattened and smoothed using a manual grinding tool prior to each rock strength measurement. A total of ten rock strength measurements are collected for each interval and are averaged to yield one rock strength value. If there is significant variability in the initial ten readings, above a standard deviation of 5 , the average value becomes null and the measurements are taken again for that interval.

The photographs that have been used as backdrops for fracture digitization are uploaded into Microsoft OneNote. By referencing these photographs, the following fracture data is retrieved and is recorded in Microsoft Excel for each outcrop: location along scan line, fracture strike \& dip, aperture, and the vertical location of termination(s) and/or step-overs. A map view representation of each outcrop scan line is created in Adobe Illustrator by creating lines for each fracture and placing them along a dashed line representing the scan line. Sets of fractures with similar strike are assigned the same color. The scan line and fractures are oriented according to field measurements, and each joint density calculation accounts for the respective scan line orientation. Abutment relationships between joint sets are based upon field observations.

\subsection{XRD Methods}

A PANalytical X'Pert PRO XRD is used to determine the percent mineral composition of 37 powdered samples. The PANalytical X'Pert PRO XRD is owned and operated by the Shared Research Facilities of West Virginia University. Samples are powdered with a mortar and pestle 
and a Spex Mixer/Mill prior to analysis. There are 33 samples from outcrops on Flat Creek and 4 samples from outcrops on Canajoharie Creek. The sampling on Flat Creek is conducted systematically throughout the vertical section; whereas the sampling on Canajoharie Creek is random and limited, but includes rocks from the Flat Creek Shale and Dolgeville Formation. The generator settings on the PANalytical X'Pert PRO XRD are set to $45 \mathrm{kV}$ and $40 \mathrm{~mA}$, and samples are measured between $10-110^{\circ} 20$.

The PANalytical X'Pert PRO XRD identifies specific minerals by measuring the constructive interference (diffraction) between X-rays and parallel planes in the crystal lattice of a mineral. Diffraction occurs when Bragg's Law is satisfied:

$$
n \lambda=2 d \sin \theta
$$

Where: $n$ is an integer, $\lambda$ is the wavelength of the X-ray, $d$ is the spacing between parallel crystal planes, and $\theta$ is the incidence of the incoming $\mathrm{X}$-ray. The orientation of planes, and the distance between planes, $d$, varies by mineral, producing a unique $2 \theta$ diffraction pattern called a diffractogram. The X'Pert HighScore Plus software package is used to match $2 \theta$ peaks of specific minerals with the sample diffractogram by comparing results with a database of known diffractograms for specific minerals. The $2 \theta$ peak matching process yields a semi-quantitative approximation of percent composition for each sample.

\section{Observations}

\subsection{Core Observations}

The Flat Creek Shale and Dolgeville Formation intervals of Utica Core 74 NY-05 are measured to the 1/16 inch $(\sim 1.6 \mathrm{~mm})$ scale to observe bedding thicknesses and sedimentologic properties. Bedding boundaries between organic-rich shales, calcilutites, and calcisiltites in both 
formations are visually apparent because the lithologies with increased amounts of detrital carbonate material exhibit a lighter gray color. The organic rich shale and calcisiltite lithofacies are end-members in terms of composition and appearance, whereas the calcilutite lithofacies is a mixture of the two. The difference in bedding thicknesses between the Flat Creek Shale and the Dolgeville Formation is distinct: the detrital carbonate-rich layers in both members generally exhibit thicknesses between .5 and 8.0 inches $(\sim 1.3 \mathrm{~cm}$ and $\sim 20.3 \mathrm{~cm})$, while the flaser, ripple, and planar laminated layers tend to be less than .5 inches $(\sim 1.3 \mathrm{~cm})$ thick. The Dolgeville Formation is defined by its greater abundance of detrital carbonate-dominated beds; therefore the average thickness of beds is greater in this formation.

The Flat Creek Shale interval is located between 465 feet and 746 feet in Utica Core 74 NY-05. The underlying Trenton-Black River Formation has a light gray color with limited dark gray shale interbedding, and mostly consists of bryozoan, trilobite, and brachiopod fossil debris. The contact between the Trenton-Black River Formation and the Flat Creek Shale is abrupt. The Flat Creek Shale consists of dark gray shale with intermittent silt-sized detrital carbonate and siliciclastic stringers, and layers with abundant crinoid and trilobite debris. Some of the fossil debris has been pyritized. Graptolites and nautaloid cephalopods are observed in outcrops of the Flat Creek Shale, but they are not apparent in the core; likely because their cross sections are less distinguishable than trilobites and crinoids. There are intervals of greater amounts of detrital carbonate beds throughout the Flat Creek Shale, especially near the upper portions. Sedimentary structures in this interval include planar lamination, wavy lamination, flaser bedding, soft sediment deformation, small scale trough cross-stratification, and burrowing. 


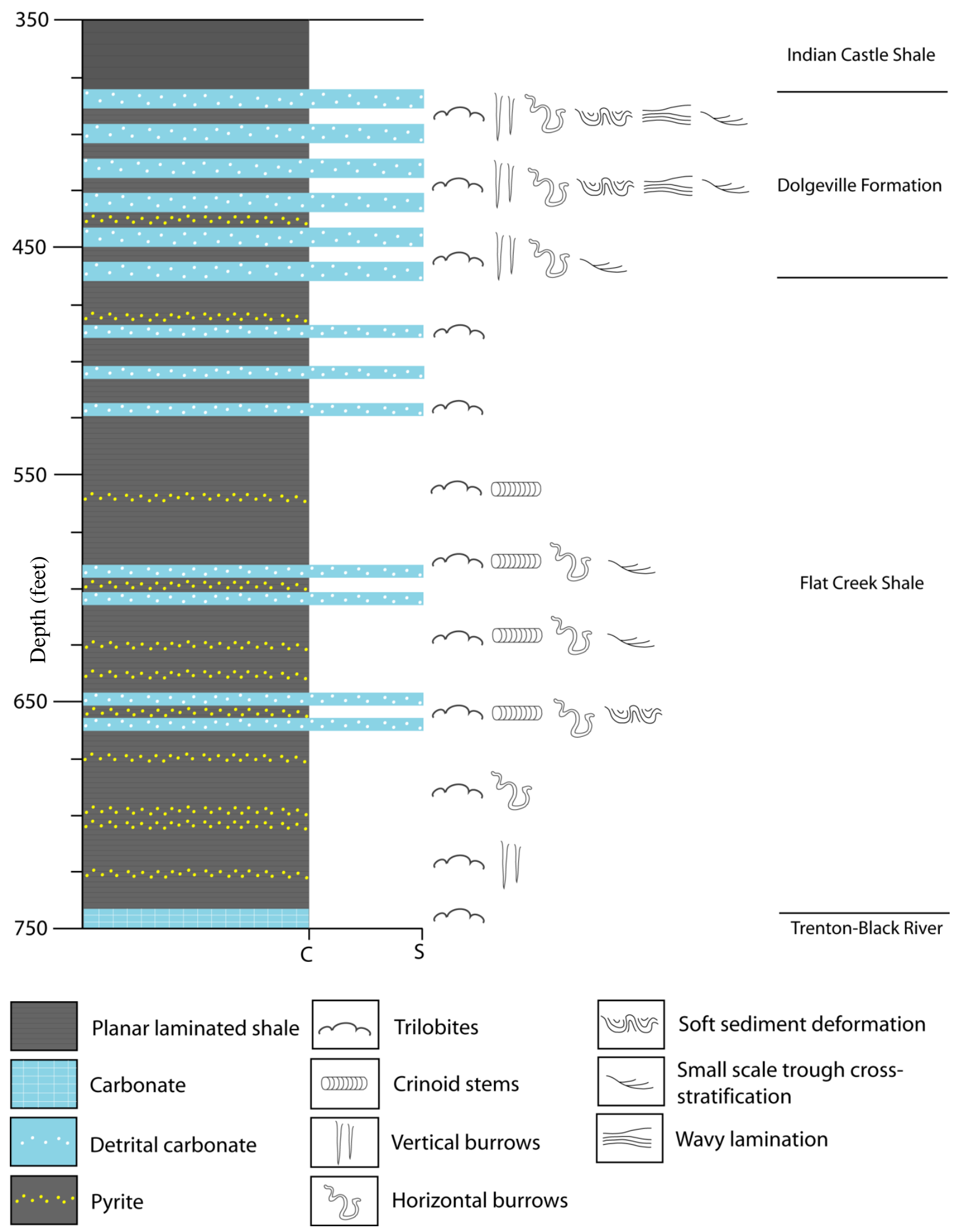

Figure 9: Utica Core 74 NY-05 Stratigraphic column. 

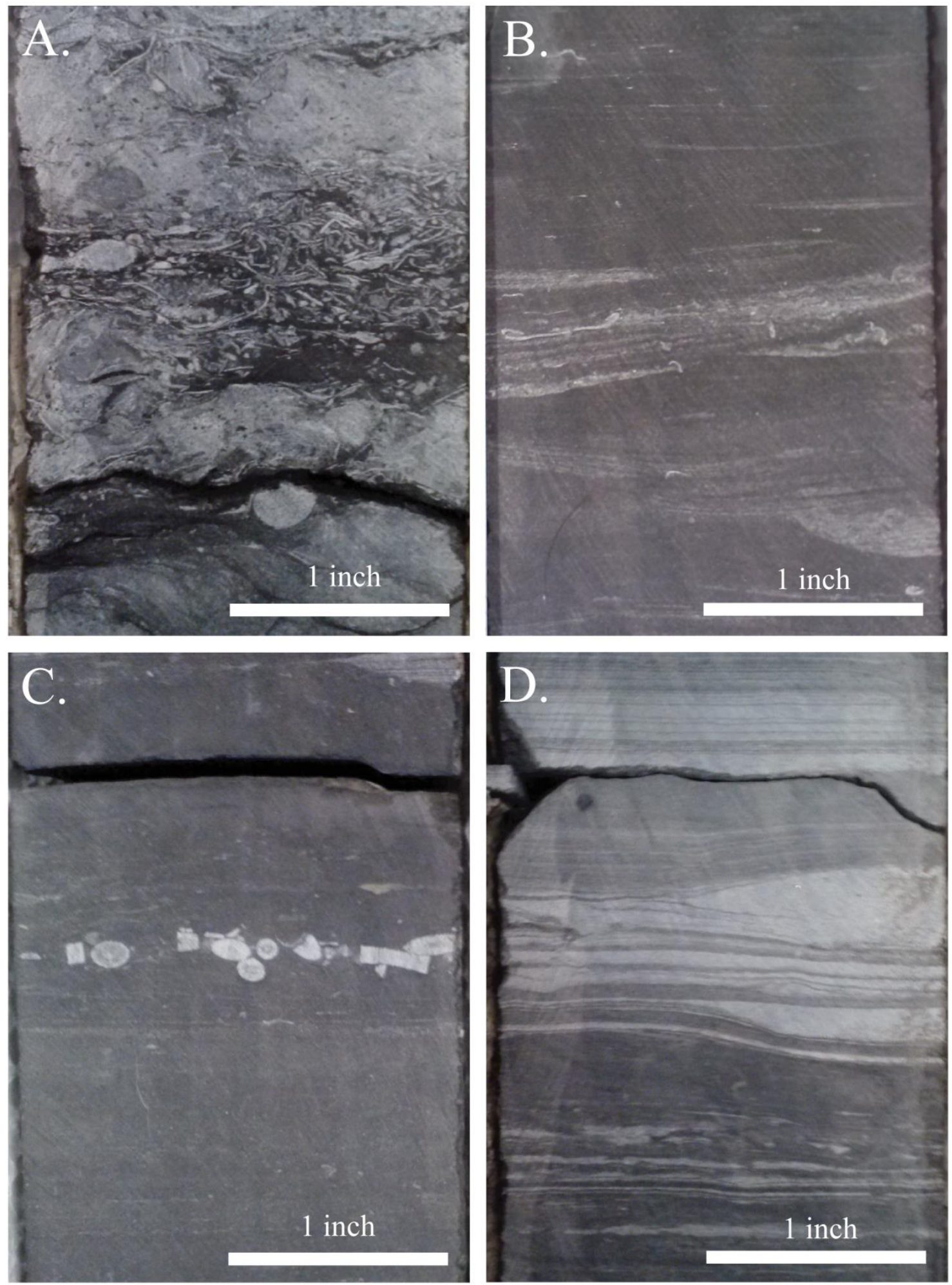

Figure 10: All images from Utica Core 74 NY-05. A. 746 ft. Trenton-Black River. Composition dominated by skeletal debris. B. $620 \mathrm{ft}$. Flat Creek Shale. Small scale trough cross stratification, trilobites, limited detrital carbonate. C. $570 \mathrm{ft}$. Flat Creek Shale. Mostly dark gray shale, crinoid fossils. D. $483 \mathrm{ft}$. Flat Creek Shale. Detrital carbonate stringers, wavy lamination. 
The transition from the Flat Creek Shale into the Dolgeville Formation is gradational, with detrital carbonate-dominated lithofacies appearing at a depth of 477 feet, 9 feet $(\sim 2.7 \mathrm{~m})$ below the $\sim 2$ inch $(\sim 5.1 \mathrm{~cm})$ thick marker bentonite and 12 feet $(\sim 3.7 \mathrm{~m})$ below the top of the Flat Creek Shale. The top of the Dolgeville Formation is picked at a depth of 385 feet in Utica Core 74 NY-05. The transition from the Dolgeville Formation to the overlying Indian Castle Shale is marked by a scoured surface and the abrupt absence of relatively thick detrital carbonate-rich beds, indicating an unconformity. The Dolgeville Formation exhibits alternating dark gray shale and light, detrital carbonate-rich gray shale, producing a ribbon-limestone appearance. Detrital carbonate-rich beds appear darker on recently exposed surfaces, dampening the color contrast. The sedimentary structures found in the Dolgeville Formation are comparable to those of the Flat Creek Shale, but the amplitude of the bedforms and the degree of soft sediment deformation is increased. There are also more scoured surfaces in this interval.


Figure 11: All images are from Utica Core 74 NY-05. A. 400 ft. Dolgeville Formation. 3 inch detrital carbonate bed. The surface color is used to estimate the relative abundance of detrital calcite. B. 455 ft. Dolgeville Formation. Planar \& wavy lamination. Detrital carbonate laminae appear light gray. Potential vertical burrow. C. 430 ft. Dolgeville Formation. Possible carbonate debris flow facies. Evidence of significant soft sediment deformation, bedding fabric nearly absent. 


\subsection{Thin Section Observations}
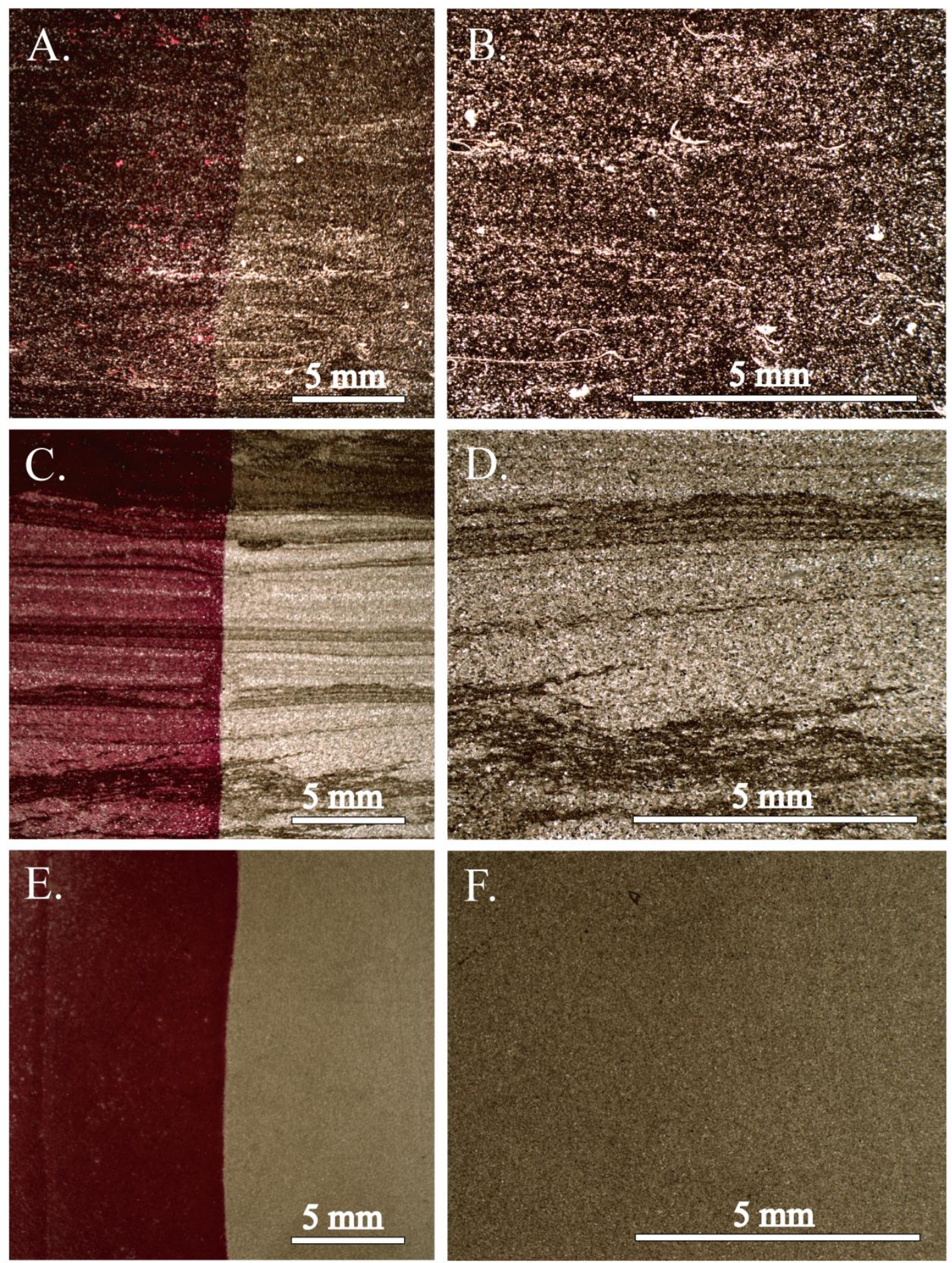

Figure 12: Thin section photographs under $0.63 x$ (left column) and 1.6x (right column) magnification under plane polarized light with an Olympus SZX10 petrographic microscope. A calcite stain is applied to the left side of samples. A\&B: Organic-rich shale lithofacies. C\&D: Calcilutite lithofacies. E\&F: Calcisiltite lithofacies. 
Mechanical properties can be assessed qualitatively by studying sedimentary textures (Lezin et al. 2009; Palchik \& Hatzor 2002). The three samples retrieved from Utica Core 74 NY-05 are studied in terms of sedimentary structures and mechanical flaws. The organic-rich shale lithofacies exhibits lamina with subtly greater and lesser amounts of quartz grains and large mechanical flaws in the form of fossil debris. The calcilutite lithofacies has the most complex sedimentary fabric of the three samples, with prominent ripple cross-lamination and detrital carbonate-rich and detrital carbonate-poor zonation. The calcisiltite lithofacies exhibits a nearly homogenous composition and sedimentary fabric. The sedimentary textures associated with these samples may not entirely characterize, nor be unique to, each lithofacies. These samples did not exhibit dolomitization or non-fabric selective cements.

Sample 1 is a fine-grained, mixed detrital carbonate and siliciclastic rock containing abundant fossil debris. This sample corresponds to the organic-rich shale lithofacies identified in Utica Core 74 NY-05. The percent composition of detrital carbonate and quartz grains is difficult to average because composition varies by individual lamina. The coarser grained intervals are composed of approximately $30 \%$ calcite and $70 \%$ quartz grains, while the more fine-grained laminae host a greater proportion of detrital calcite grains and dark brown and/or opaque matrix. Fossil debris is common throughout the sample. The size of detrital calcite and quartz grains ranges between $.01 \mathrm{~mm}$ and $.1 \mathrm{~mm}$. These grains are well sorted, sub-angular to well-rounded, and exhibit variable sphericity. The matrix composition is not entirely apparent, but some organic material is identified under UV light (Figure 13A). The remaining matrix likely includes pyrite and mud. The fossils in sample 1 are large compared to the fossils in samples 2 and 3. Trilobites are the largest of the skeletal allochems in sample 1, reaching a length of $5 \mathrm{~mm}$. This sample is interpreted to include the following additional fossil specimens: 
crinoid columnals, brachiopods, and ovoid fossils of unknown identity. Some of the ovoid fossils respond to the calcite stain, while others do not. Additionally, a quartz overgrowth is interpreted on one of the calcite ovoid fossils (Figure 13B). There are also intragranular isopachous cements in some fossil specimens (Figure 13C).


Fig 13: Organic-rich shale lithofacies at 10x2x magnification. An Olympus BX53 petrographic microscope is used for these images. A: Abundant organic material responding to UV light (orange color). B: Multiple ovoid fossils composed of calcite. The red color is due to the calcite stain. One of the ovoid fossils has what is interpreted to be a quartz overgrowth. Plane polarized light. C: Brachiopod with isopachous intragranular calcite cement. Plane polarized light.

Sample 2 is also a fine-grained, mixed detrital carbonate and siliciclastic rock, but it contains a greater proportion of detrital carbonate grains and less organic material than the organic-rich shale lithofacies (Figure 14A). This sample corresponds to the calcilutite lithofacies identified in Utica Core 74 NY-05 and is composed of approximately $60 \%$ detrital calcite, $20 \%$ detrital quartz, and $20 \%$ fossils and opaque matrix. Percent composition is not derived from point counting, and is only meant to establish the relative amount of detrital carbonate grains in this lithofacies. Similar to sample 1, sample 2 exhibits varying amounts of quartz grains with respect to individual laminae. The boundaries between composition-defined zones are very sharp in this sample. The size of the calcite and quartz grains ranges between $.01 \mathrm{~mm}$ and .2 
$\mathrm{mm}$. These grains are moderately sorted, angular to rounded, and exhibit moderate to high sphericity. Some of the quartz grains are euhedral and have quartz coatings (Figure 14C). Sample 2 has a diverse fossil assemblage that includes trilobites, sponge spicules, foraminifera, and fossil debris of unknown identity (Figure $14 \mathrm{~B}$ ). The fossils in sample 2 are smaller than those in sample 1, ranging between $.05 \mathrm{~mm}$ and $.2 \mathrm{~mm}$.
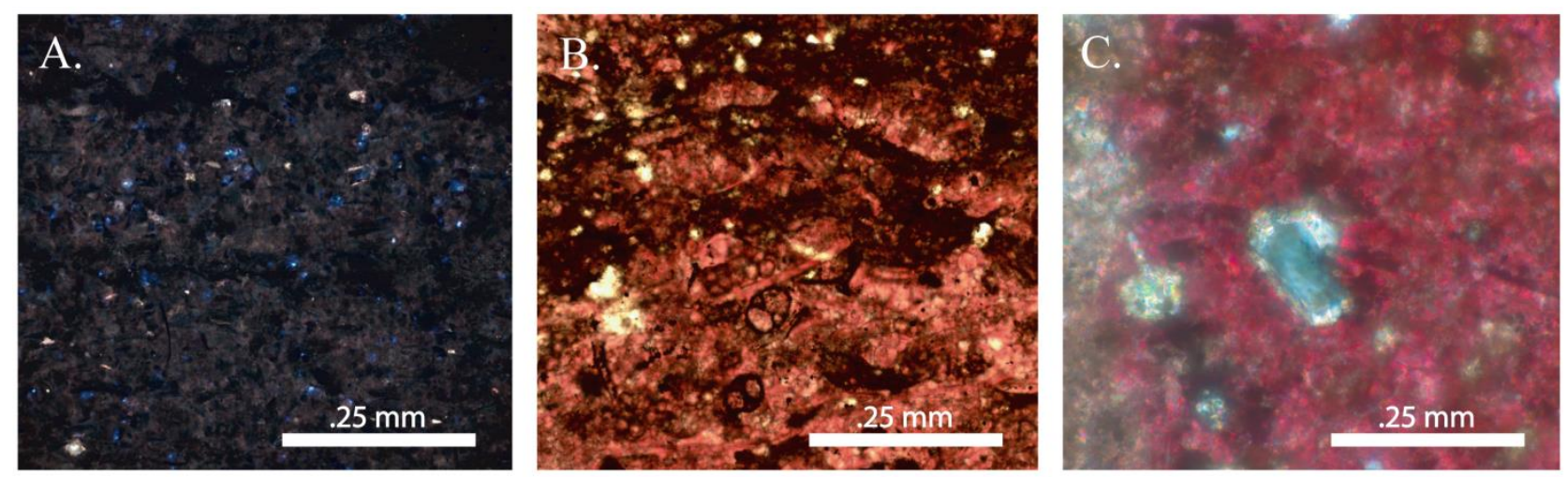

Figure 14: Calcilutite lithofacies at 10x2x magnification. An Olympus BX 53 petrographic microscope is used for these images. A: Organic material responding to UV light (yellow-orange color). B: Foraminifera and other fossil debris. Plane polarized light. Quartz overgrowth around euhedral quartz grain. Cross polarized light.

Sample 3 from Utica Core 74 NY-05 is predominantly composed of silt-sized detrital carbonate, but some of the grains appear to be smaller (Figure 15B). Sample 3 is identified as a calcisiltite in the core based upon its lighter gray color. This sample is estimated to consist of $95 \%$ detrital calcite, $3 \%$ quartz, and $2 \%$ opaque material. Organic content is limited in this sample (Figure 15A). Most of the detrital calcite grains are less than $.01 \mathrm{~mm}$ in diameter. The calcite grains are well sorted, sub-rounded to well rounded, and exhibit high sphericity. Most of the opaque material is fossil debris that has likely been replaced by pyrite. Reflected light reveals that the opaque material is metallic, and its morphology is consistent with disseminated 
pyrite (Figure 15C). Pyrite has also been observed in the core and outcrop, and is identified by XRD.
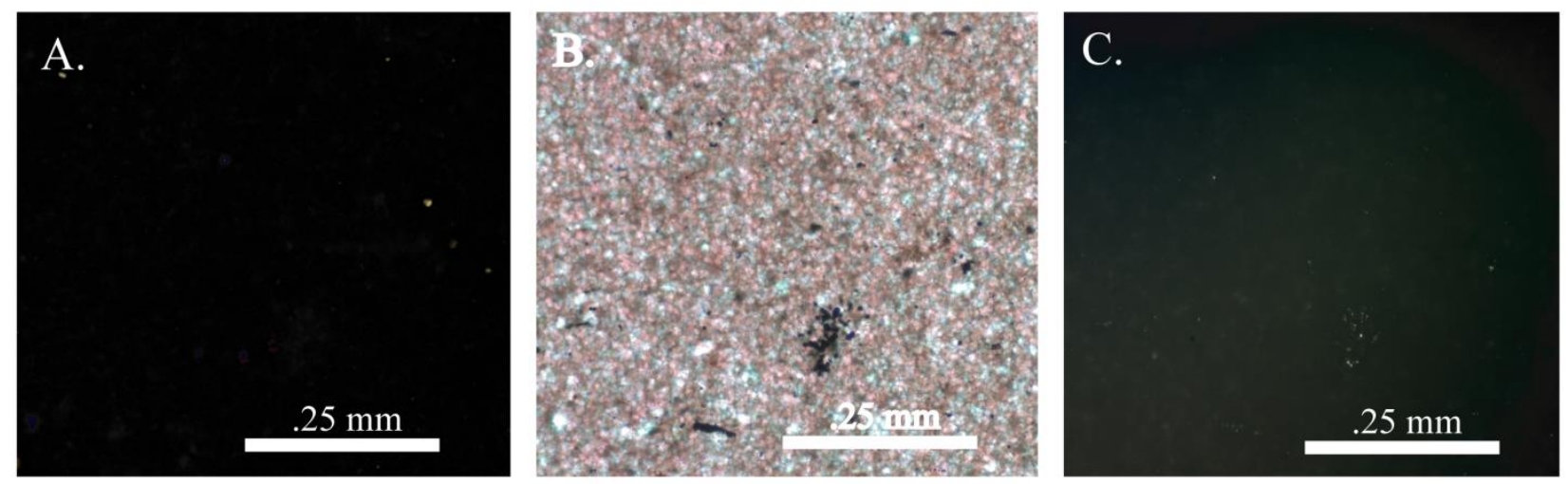

Figure 15: Calcisiltite lithofacies at 10x2x magnification. An Olympus BX53 petrographic microscope is used for these images. Each of these images captures the same location on the thin section. A: Limited organic material responding to UV light. B: Well sorted silt-sized detrital carbonate grains. Opaque, disseminated pyrite. Plane polarized light. C: Pyrite responding to reflected light.

\subsection{Field Observations}

The stratigraphic location of outcrops on Canajoharie Creek and Flat Creek are identified by the ribbon-limestone appearance of the Dolgeville Formation, and by utilizing the thick bentonite near the top of the Flat Creek Shale as a marker bed (Figure 16). In outcrop, the bentonites are preferentially weathered and produce a brown stain on the outcrop surface. Scree and exposed bedding surfaces often exhibit trilobites, graptolites, nautaloid cephalopod fossils, and rare ripple marks (Figure 18). The surface of each creek bed provides a pavement for characterizing fracture abutment relationships and for measuring fracture density. The predominant joint set throughout both intervals strikes approximately E-W (280ªzimuth), is filled with calcite, and has a nearly vertical dip. Some calcite-fill is less apparent when the aperture of the joint is minimal. The fractures that do not strike E-W are less likely to exhibit a 
calcite fill. The relative timing of fracture sets is not thoroughly explored, but cursory observation indicates that the NE-SW set occasionally terminates at the E-W set, indicating that the E-W set formed first. There is also evidence of right lateral and left lateral slip sense strike slip motion, in the form of vein-filled rhombochasms, present at both field locations.
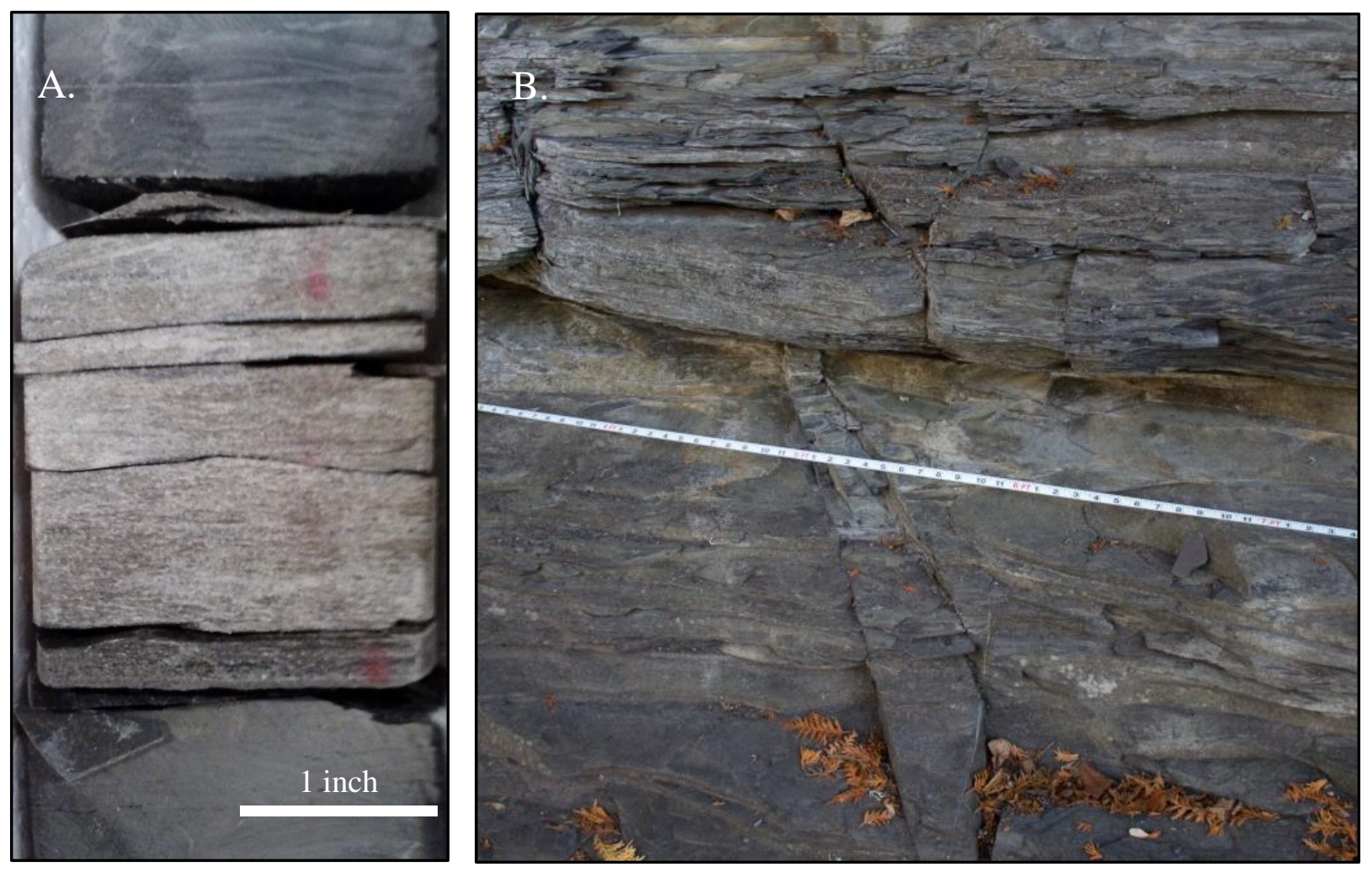

Figure 16: A. Marker bentonite in Utica Core 74 NY-05. B. Marker bentonite (just above measuring tape) at the Canajoharie Creek outcrop. The bentonite is a useful bed for correlation because its thickness is much greater than the other bentonites, and it is situated directly below the base of the Dolgeville Formation in the outcrops and Utica Core 74NY-05. 


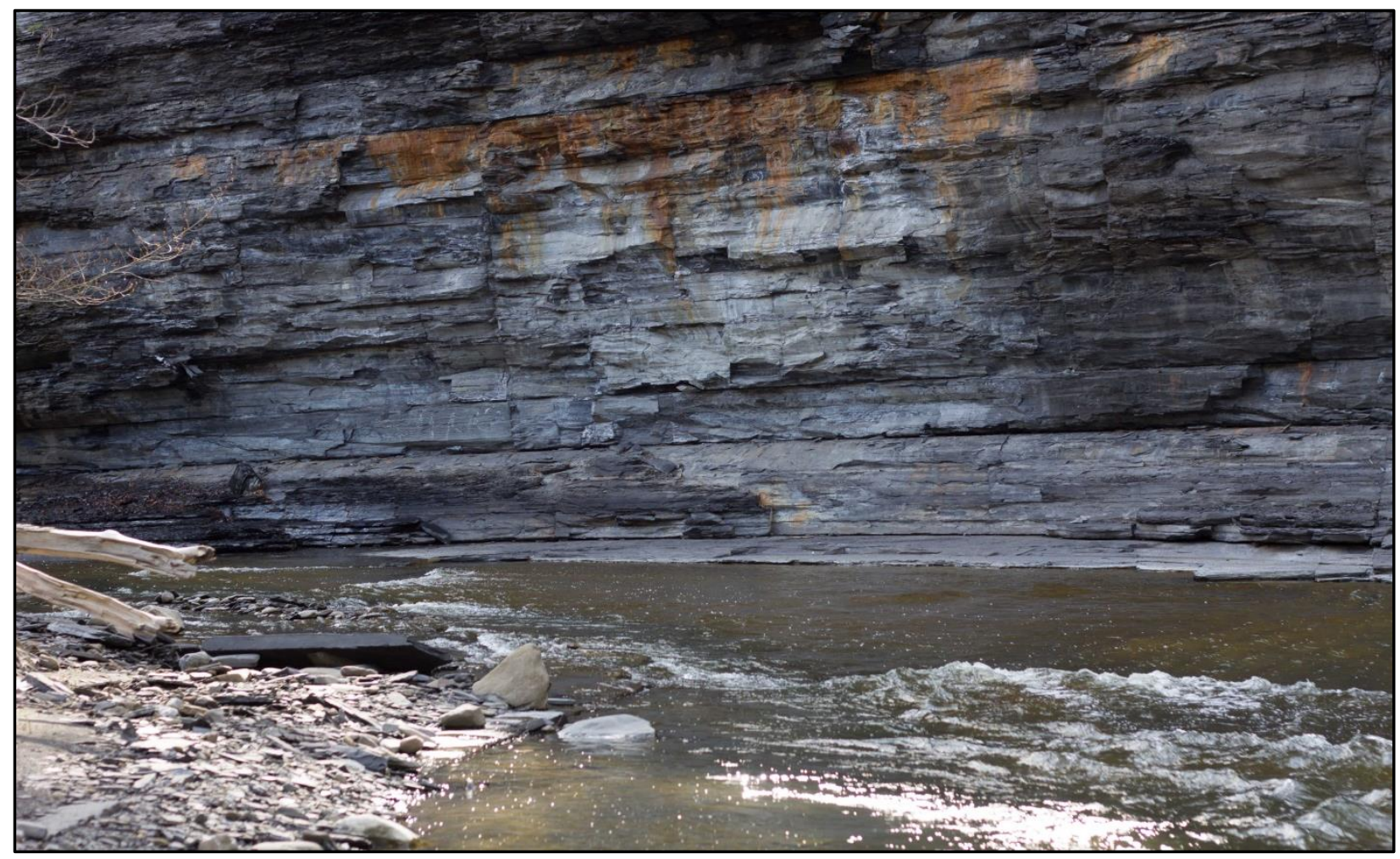

Figure 17: Lower Flat Creek Section. The brown stain on the outcrop surface is a result of weathering of the overlying bentonite horizon and the oxidation of iron-bearing minerals. The fracture-bedding termination analysis is conducted along the base of the outcrop. The Flat Creek Shale is usually a homogenous dark gray color and lacks the ribbon limestone appearance of the Dolgeville Formation.
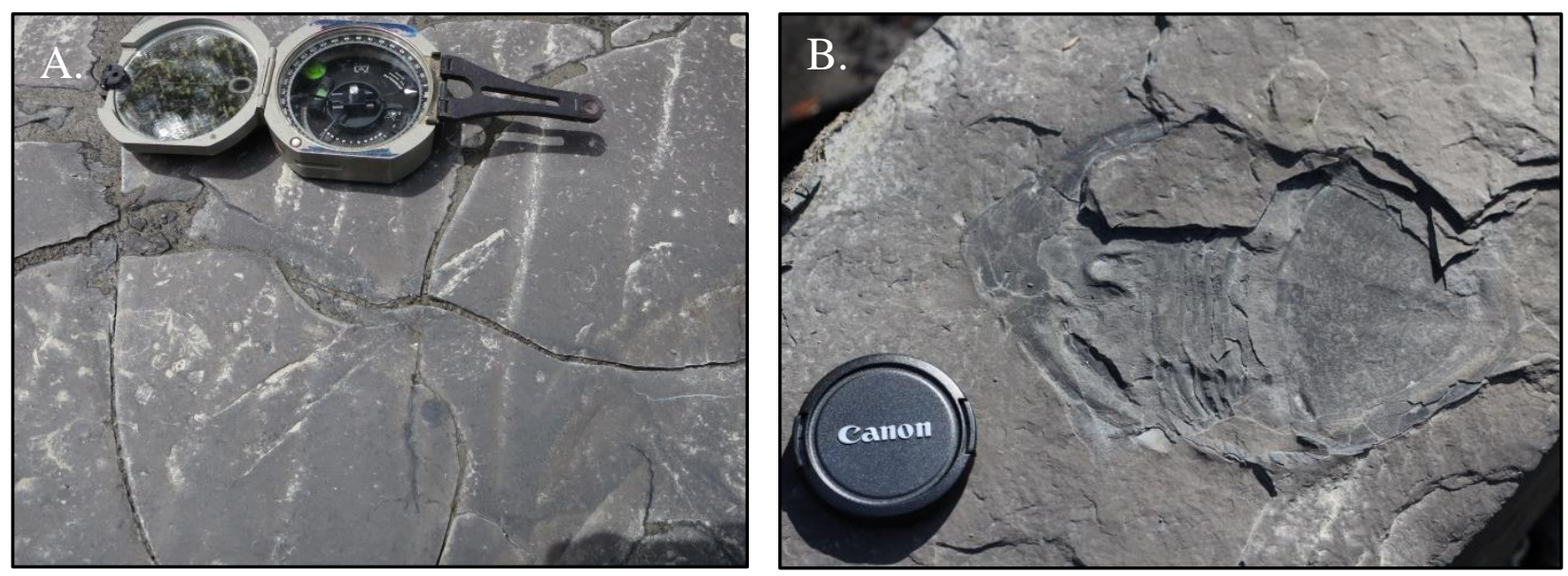

Figure 18: Flat Creek Shale fossil specimens. A. Nautaloid cephalopods, trilobites, and ripple marks. These are the only ripple marks identified on Flat Creek. This bed is located near the Mid Flat Creek section. B. Large trilobite found downstream from the Lower Flat Creek section. 

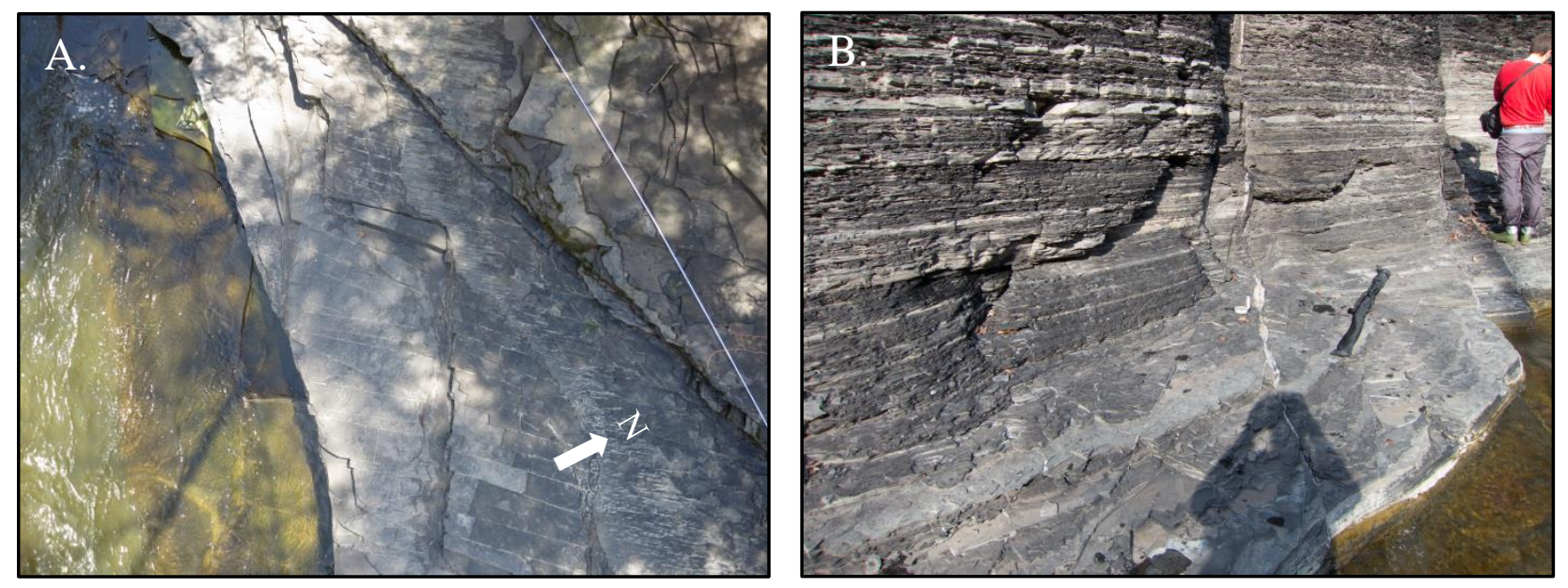

Figure 19: Dolgeville Formation outcrops on Flat Creek. A. View looking down on Dolgeville Formation pavement. Un-filled fracture spacing is very low. B. The transition from the Flat Creek Shale into the Dolgeville Formation is distinguished by the appearance of ribbon limestones. This photograph captures a vein-filled fracture swarm and mineral-filled rhombochasms.

\section{Results}

\subsection{Flat Creek Field Results}

The Flat Creek Shale and Dolgeville Formation outcrop on Flat Creek near Canajoharie, NY (Figure 20). A total of four outcrops are studied on Flat Creek near the intersection of Carlisle Rd. and Lincoln Rd. and downstream about 1 mile to the NE along Canyon Rd. Working in this field location requires permission from local residents. Flat Creek can be accessed from multiple locations along Carlisle $\mathrm{Rd}$. and Canyon $\mathrm{Rd}$.

Only one of the four outcrops on Flat Creek is specifically correlated to Utica Core 74 NY-05. Correlations that are based upon the spacing between bentonite layers in outcrops and core are uncertain. The Flat Creek Shale outcrops on Flat Creek are interpreted to reside within the upper 100 feet of the formation. The lower outcrop section likely corresponds to the depth interval between 555 feet and 575 feet in Utica Core 74 NY-05. The lower outcrop and core are correlated based upon the frequency of bentonites in the vertical section and an approximation of 
the vertical distance between the large marker bentonite and the Lower Flat Creek section. The outcrops on Flat Creek are continuous (no offset from faulting is apparent), but vertical distances are difficult to estimate because the bedding dip is near zero and the outcrops are laterally distant from one another. The Mid Flat Creek outcrop is approximately stratigraphically 25 feet above the Lower Flat Creek outcrop; therefore the rocks at this location likely correspond to the interval between 540 feet and 550 feet in Utica Core 74 NY-05. The Upper Flat Creek section is confidently correlated to the top four meters of the Flat Creek Shale by the thick marker bentonite. The specific stratigraphic location of the Dolgeville Formation outcrop on Flat Creek is unknown.

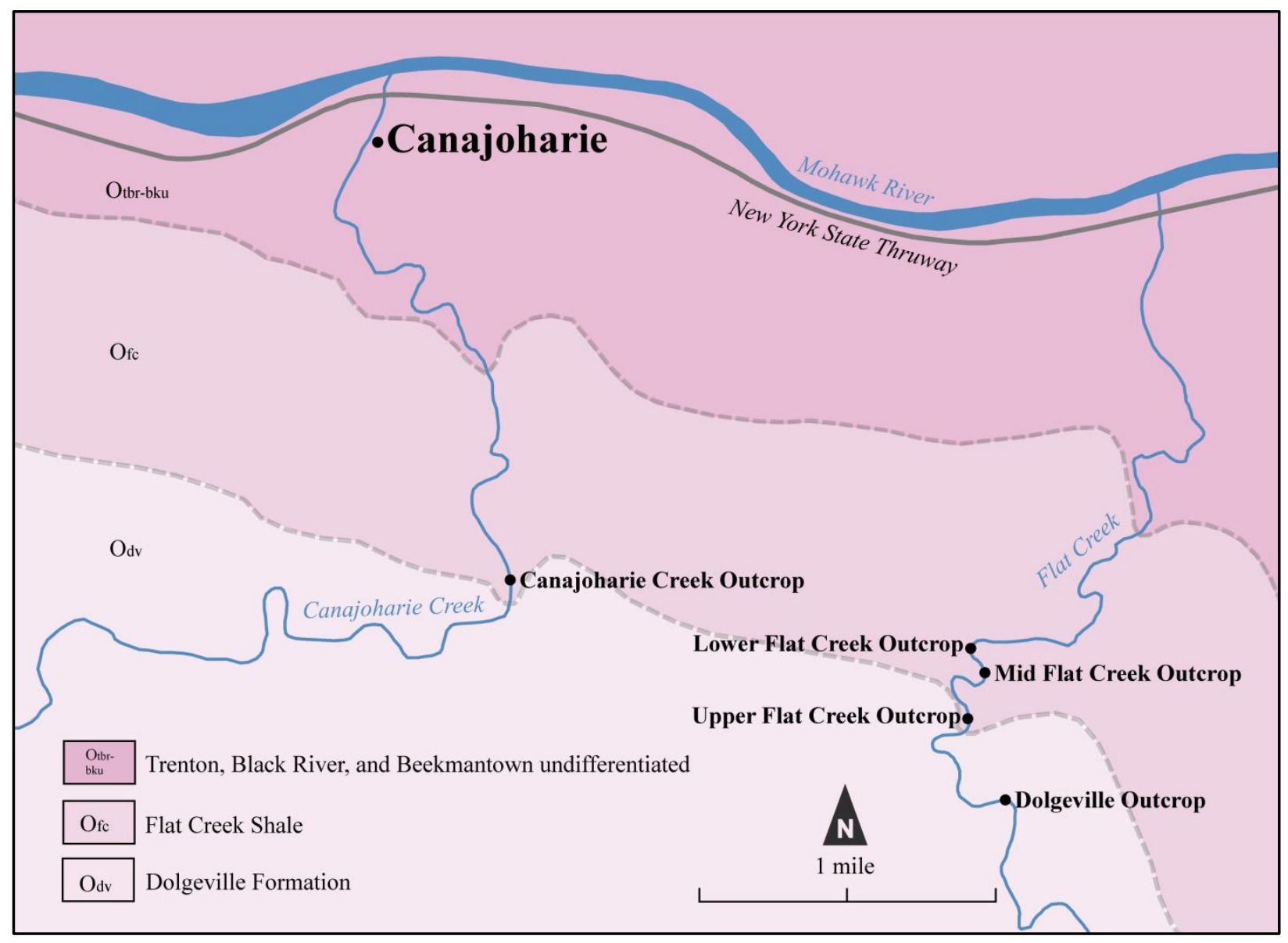

Figure 20: Outcrop locations on Canajoharie Creek and Flat Creek. 
The Lower Flat Creek outcrop is located at 42.872085, - 74.534420 and includes a section of the Flat Creek Shale. The terminus of some vein-filled fractures cannot be identified at this location because there is muddy-grime on the surface of the outcrop near creek level. Two scan lines are conducted at this location: Lower Flat Creek 1 and Lower Flat Creek 2. The Lower Flat Creek $1 \mathrm{E}-\mathrm{W}$ joint set density is calculated by correcting for a $035^{\circ}$ scan line orientation. There are $0.70 \mathrm{E}-\mathrm{W}$ joints per meter along the Lower Flat Creek 1 scan line (Figure 21). This value likely underestimates joint density because a small waterfall obscures surficial features in the middle of the scan line. If the waterfall is arbitrarily assumed to negate $10 \mathrm{~m}$ of the scan line, the joint density of the Lower Flat Creek 1 scan line increases to approximately .9 joints per meter. A second scan, Lower Flat Creek 2, is conducted in the same stratigraphic interval but further downstream. The orientation of the Lower Flat Creek 2 scan line is $045^{\circ}$. The E-W joint set density along this scan line is 3.55 joints per meter (Figure 21). The variability in joint density between the Lower Flat Creek 1 and 2 scan lines may be accounted for by a swarming tendency of the joints; however, the waterfall may also be hiding the presence of additional E-W joints in the Lower Flat Creek 1 scan line.

The second outcrop, Mid Flat Creek, is located at 42.871034, - 74.533869. There is one scan line at this location with an orientation of $340^{\circ}$. After accounting for scan line orientation, the joint density of the E-W set is calculated as 2.32 joints per meter (Figure 22). The E-W set is dominant in this location, with only three other joints striking WNW-ESE. In contrast to the Lower Flat Creek 1 scan line there is less of a swarming nature to these joints. 


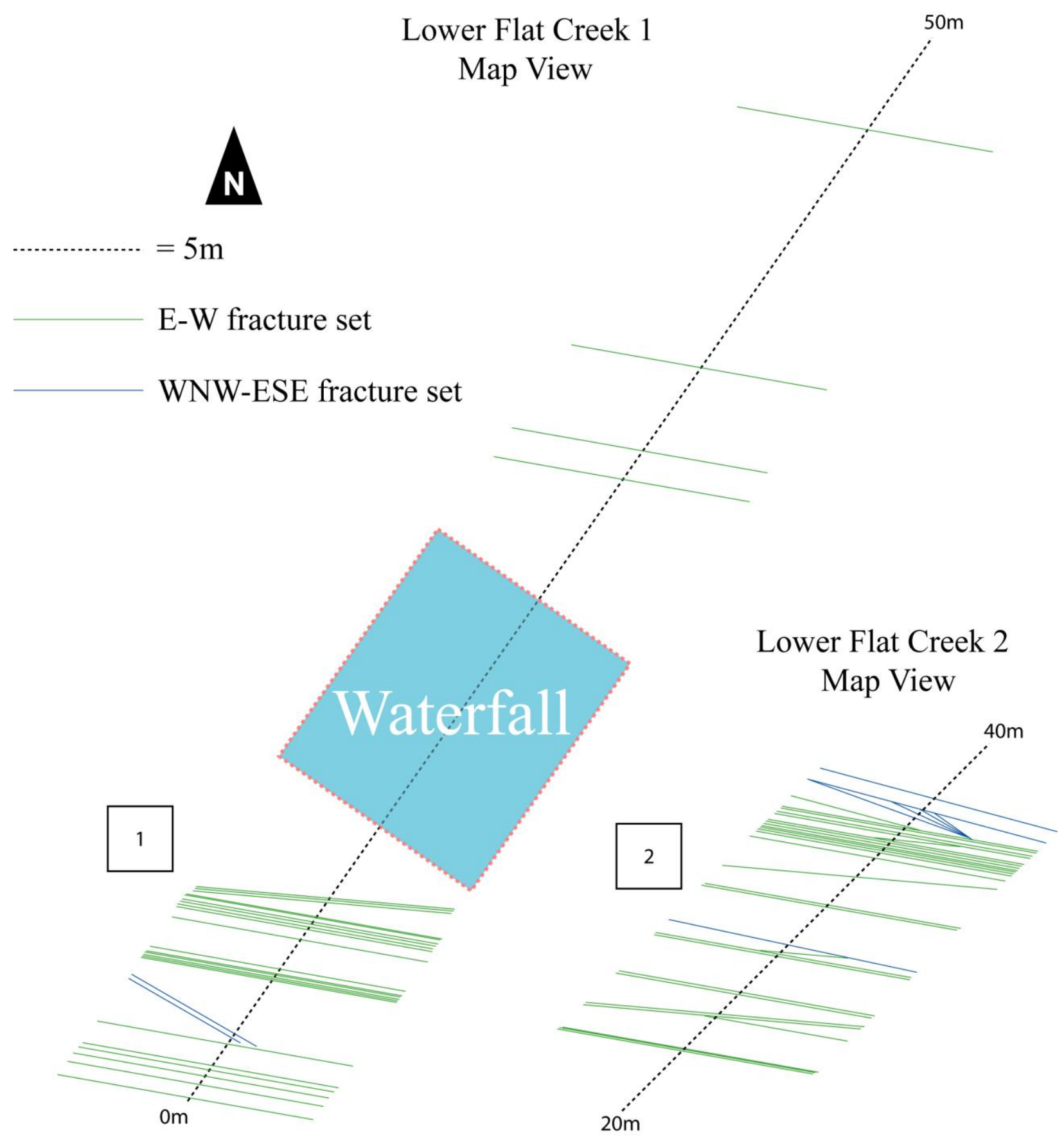

Figure 21: Map view representation of fractures along scan lines in the lower section of the Flat Creek Shale along Flat Creek. The E-W fracture set encompasses fractures with an orientation between $260^{\circ}$ and $280^{\circ}$. The WNW-ESE fracture set encompasses fractures with an orientation greater than $280^{\circ}$ and less than $300^{\circ}$. 


\section{Middle Section \\ Map View}



Figure 22: Map view representation of fractures along scan lines in the middle section of the Flat Creek Shale along Flat Creek. The E-W fracture set encompasses fractures with an orientation between $260^{\circ}$ and $280^{\circ}$. The WNW-ESE fracture set encompasses fracture with an orientation greater than $280^{\circ}$ and less than $300^{\circ}$.

The uppermost Flat Creek Shale section on Flat Creek is located at 42.868505, -

74.535437. While lithofacies are more difficult to constrain in the field, this interval likely includes a greater number of detrital carbonate-rich beds based upon observations of Utica Core 74 NY-05. The orientation of the scan line in this location is $185^{\circ}$. The joint density of the E-W set along this scan line is 0.25 joints per meter; however the joint density of the WNW-ESE joint set is .44 joints per meter. If both joint sets are considered in the density calculation, the joint density in the uppermost Flat Creek Shale is .66 joints per meter (Figure 23). 


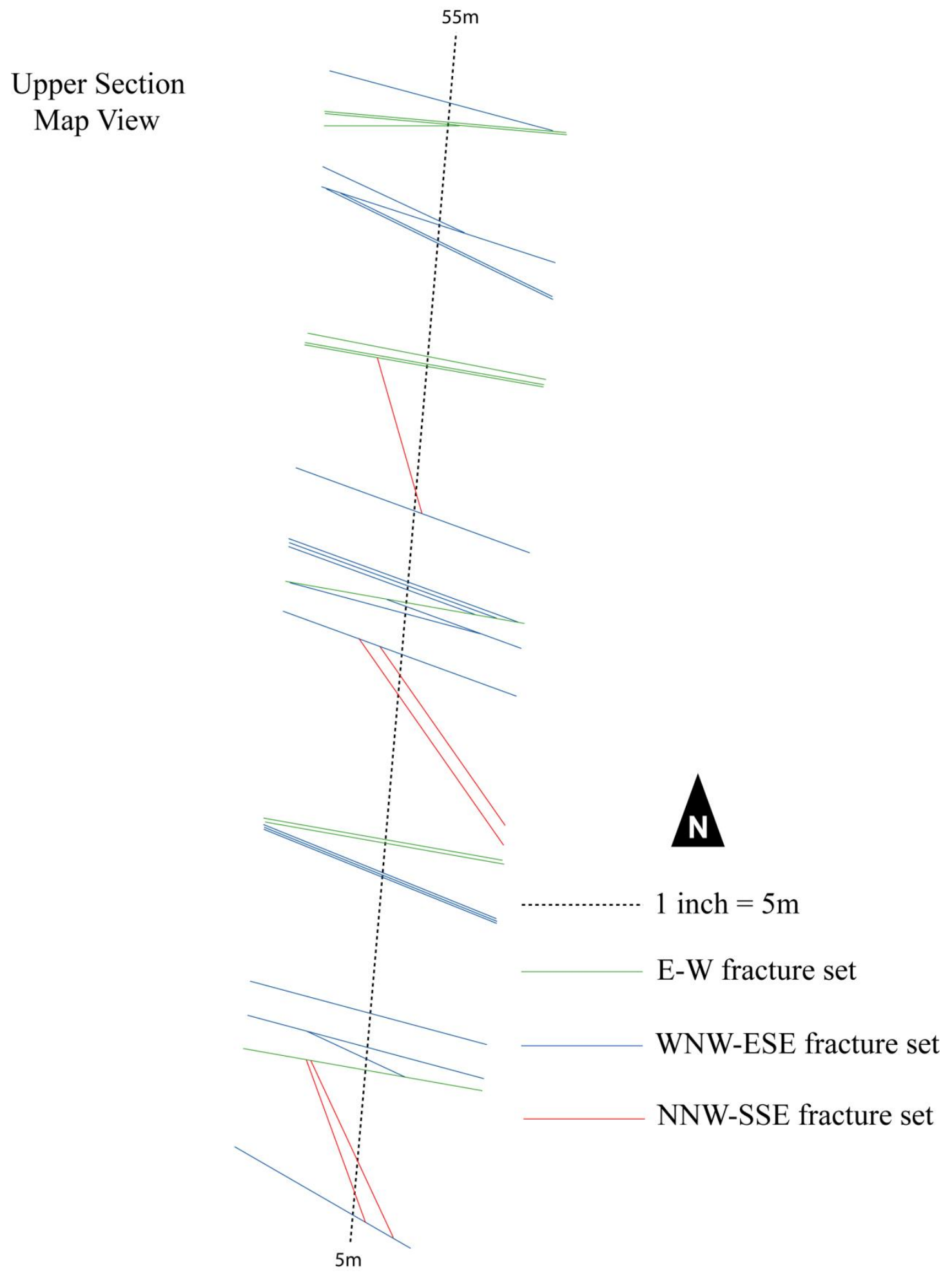

Figure 23: Map view representation of the Upper Section of the Flat Creek Shale on Flat Creek. The E-W fracture set encompasses fractures with an orientation between $260^{\circ}$ and $300^{\circ}$. The WNW-ESE fracture set encompasses fractures with an orientation greater than $280^{\circ}$ and less than $30^{\circ}$. The NNW-SSE fracture set encompasses fractures with an orientation between $325^{\circ}$ and $345^{\circ}$. 


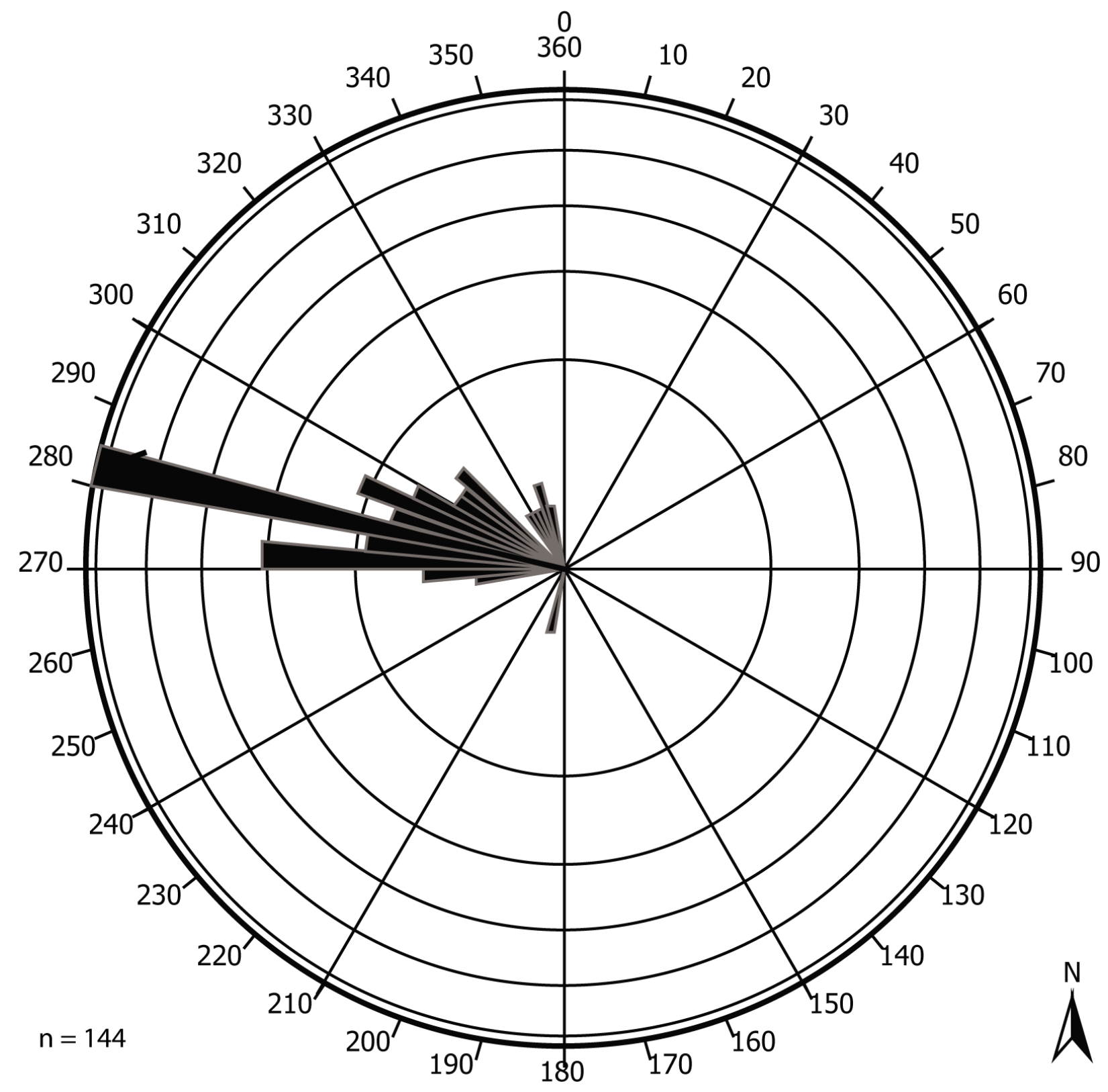

Figure 24: Rose diagram of Flat Creek joint azimuths. This diagram includes the joint orientation measurements from all of the scan lines on Flat Creek.

The final outcrop on Flat Creek includes a section of the Dolgeville Formation and is located at 42.864161, -74.534136. Joint density is difficult to determine in the Dolgeville Formation. The density of un-filled fractures is much greater in the Dolgeville Formation than it is in the Flat Creek Shale, but the density of vein-filled fractures is much lower. The nearest two 
E-W vein-filled fractures are approximately $5 \mathrm{~m}$ apart at this location. Further downstream there is a fracture swarm in the Dolgeville Formation with greater vein-filled fracture density (Figure 19). The fractures without calcite vein-fill vary in density and orientation with respect to each rock bed. The dominant fracture orientation tends to range between $030^{\circ}$ and $045^{\circ}$. There also appears to be a strong correlation between fracture density and bedding thickness based upon qualitative assessment (Figure 25).

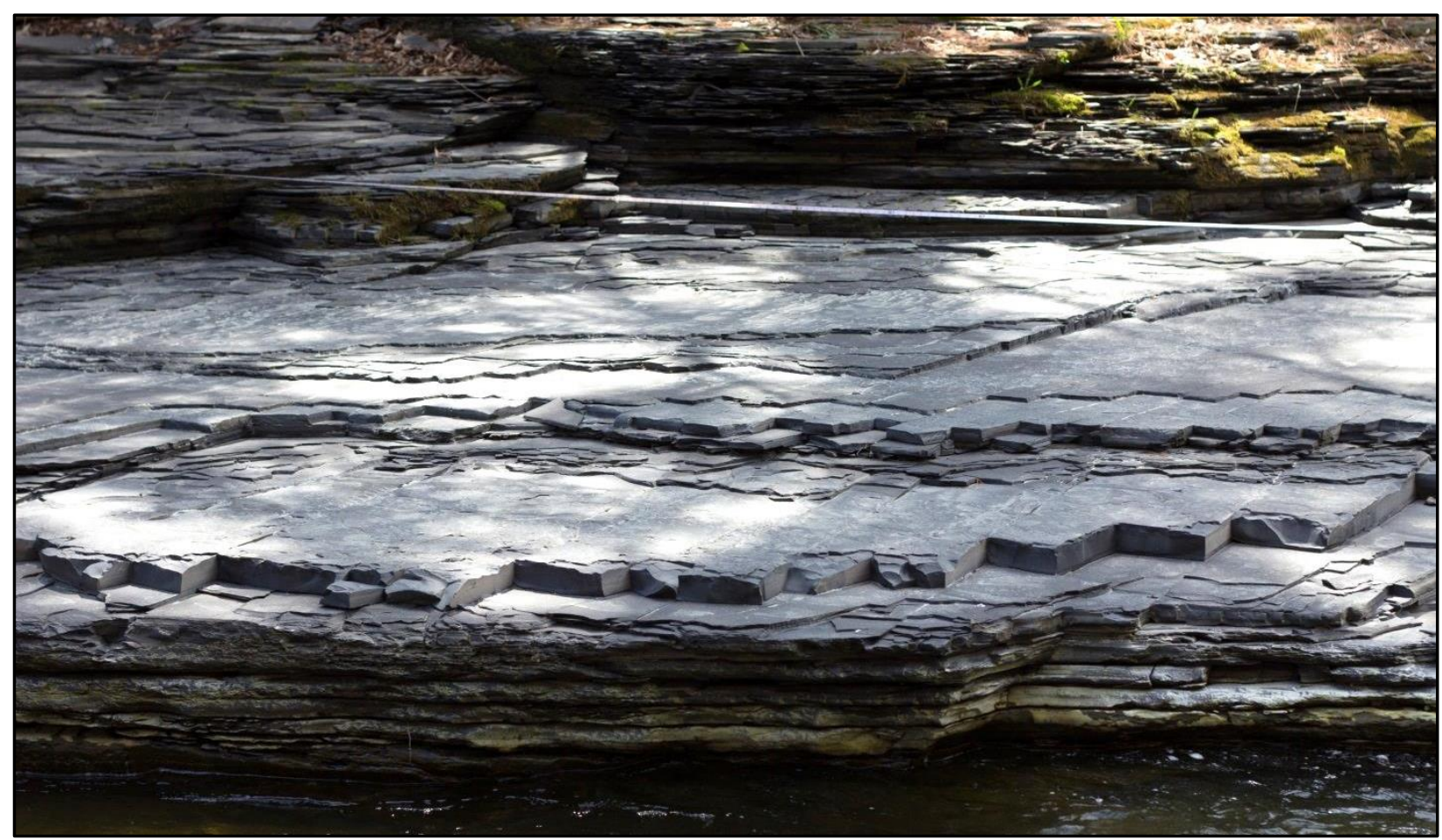

Figure 25: Outcrop image of the Dolgeville Formation. The fractures in this image lack calcite vein-fill, and the orientation of the fractures often varies with respect to discrete bedding units. A relationship between bedding thickness and joint spacing is observed.

\subsection{Canajoharie Creek Field Results}

The Flat Creek Shale is exposed along Canajoharie Creek in Wintergreen Park near Canajoharie, NY. One outcrop on Canajoharie Creek is correlated to the uppermost Flat Creek Shale by the thick marker bentonite. This outcrop is located at $42.879339,-74.565355$ and 
includes a portion of the Upper Flat Creek Shale. A total of nine scan lines are conducted at this location. The fracture density of the E-W set for each scan line is: $2.03,2.04,0.89,1.89,5.51$, $1.74,2.64,0.62$, and 0.41 joints per meter, respectively. The E-W joint set density is observed to decrease in the uppermost portion of the outcrop, above the same marker bentonite seen on Flat Creek and in Utica Core 74 NY-05. The density of fractures without calcite vein-fill increases in the upper portions of this outcrop.

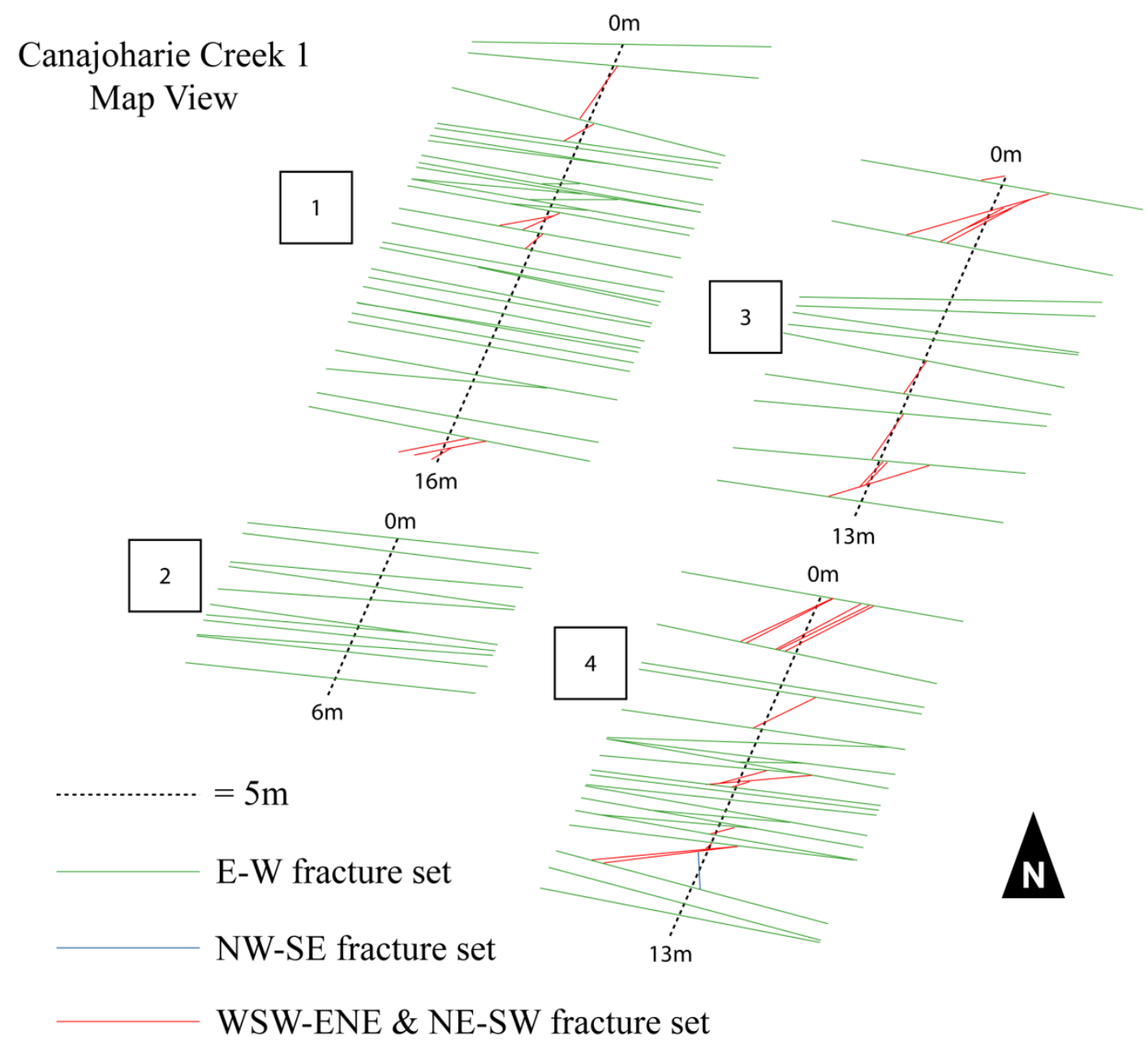

Figure 26: Map view representation of Canajoharie Creek 1 scan lines. The E-W fracture set encompasses fractures with an orientation between $260^{\circ}$ and $280^{\circ}$. The NW-SE fracture set encompasses fractures with an orientation greater than $300^{\circ}$ and less than $340^{\circ}$. The ENE-WSW $\&$ NE-SW fracture set encompasses fractures with any strike between $180^{\circ}$ and $260^{\circ}$. 


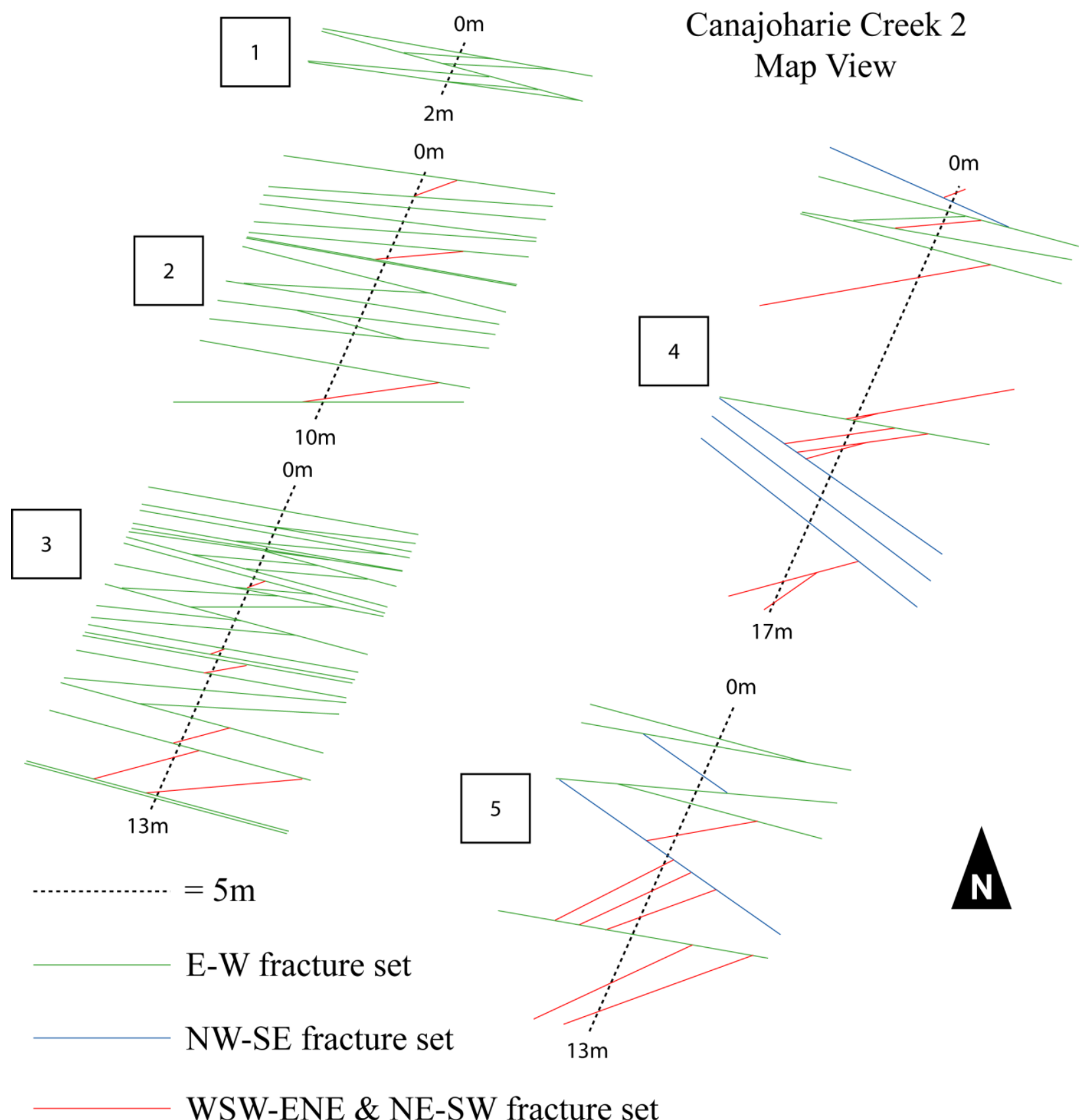

Figure 27: Map view representation of Canajoharie Creek 2 scan lines. The E-W fracture set encompasses fractures with an orientation between $260^{\circ}$ and $280^{\circ}$. The NW-SE fracture set encompasses fractures with an orientation greater than $300^{\circ}$ and less than $340^{\circ}$. The ENE-WSW $\&$ NE-SW fracture set encompasses fractures with any strike between $180^{\circ}$ and $260^{\circ}$. 


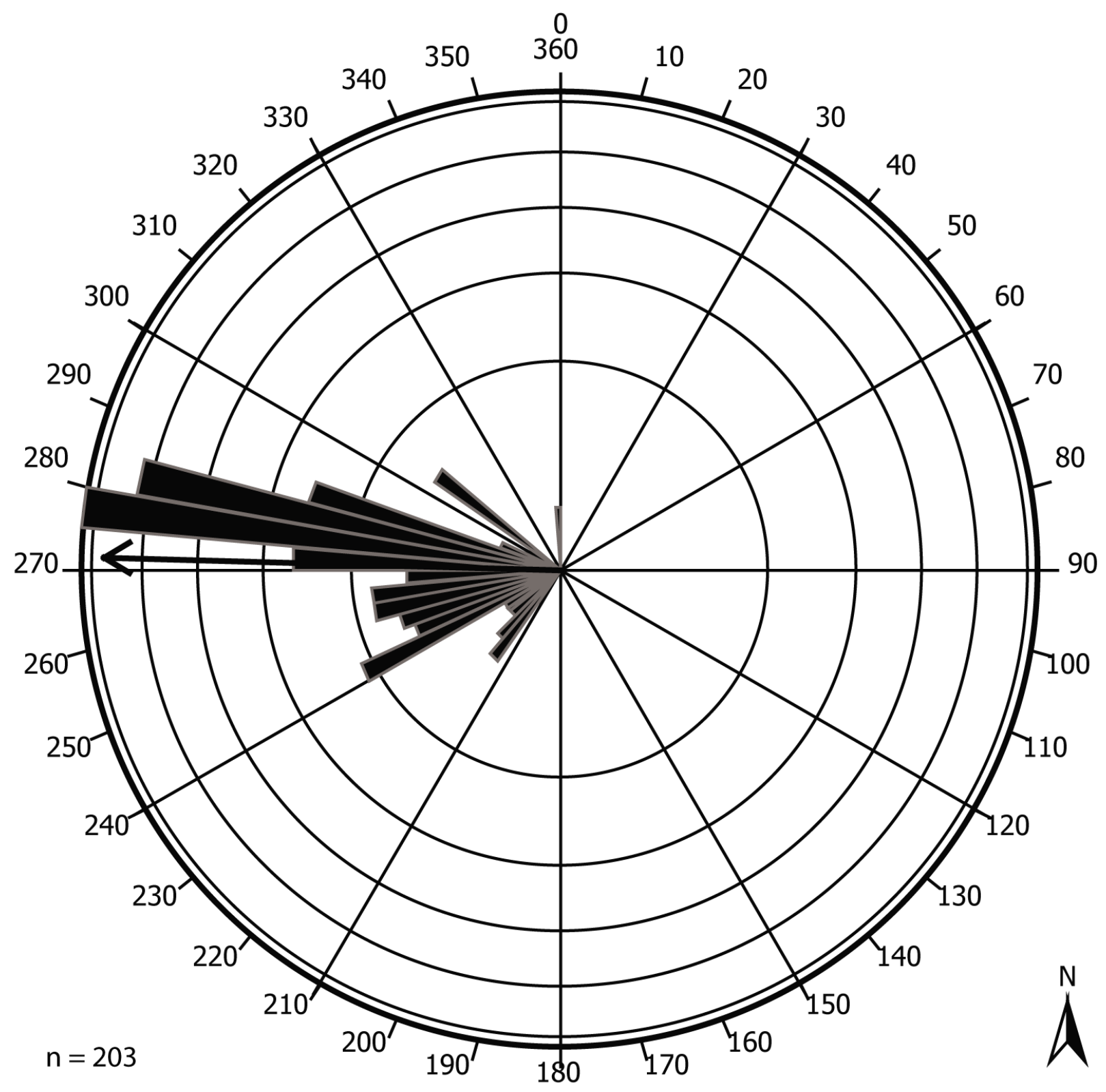

Figure 28: Rose diagram of Canajoharie Creek joint azimuths. This diagram includes all of the joint orientation measurements from Canajoharie Creek scan lines. The dominant joint set is oriented approximately $280^{\circ}$.

\subsection{Fracture Bedding Termination Analysis}

A fracture bedding termination analysis is conducted at three Flat Creek Shale outcrops on Flat Creek. Joint terminations are categorized by the medium in which joints cease. The 
categories include: shale, bentonite, and unknown. An unknown category is necessary because many terminations cannot be identified due to the weathered nature of the outcrops, and because some joints extend into the subsurface. The shales are not differentiated between detrital carbonate-rich and detrital carbonate-lean because this distinction is not always apparent from observations of these rocks in the field. The purpose of the fracture bedding termination analysis is to identify the rock layers that act as mechanical interfaces.
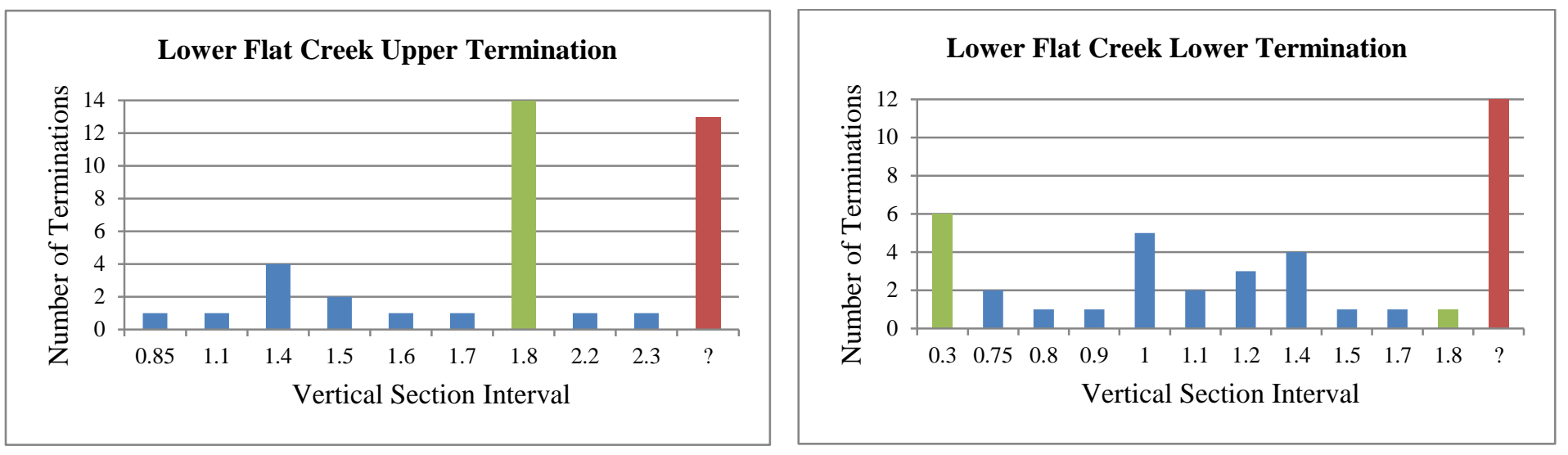

Figure 29: Count of upper and lower joint terminations by vertical interval in the Lower Flat Creek section. Bars are color coded by medium: green $=$ bentonite; blue $=$ shale; and red $=$ unknown.
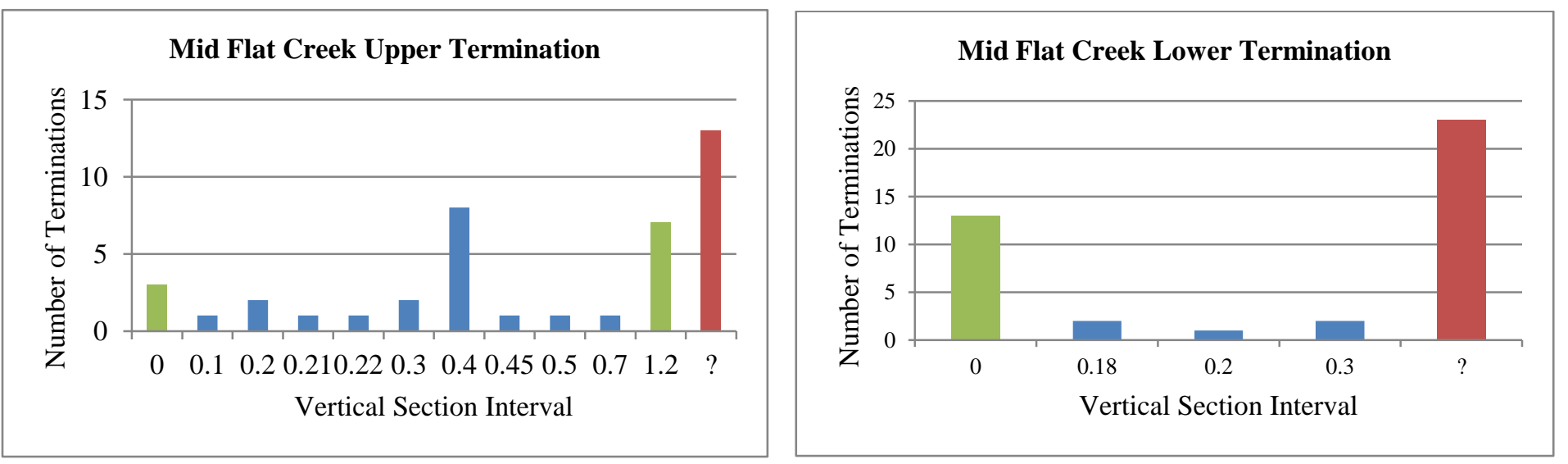

Figure 30: Count of upper and lower joint terminations by vertical interval in the Mid Flat Creek section. Bars are color coded by medium: green = bentonite; blue = shale; and red = unknown. 

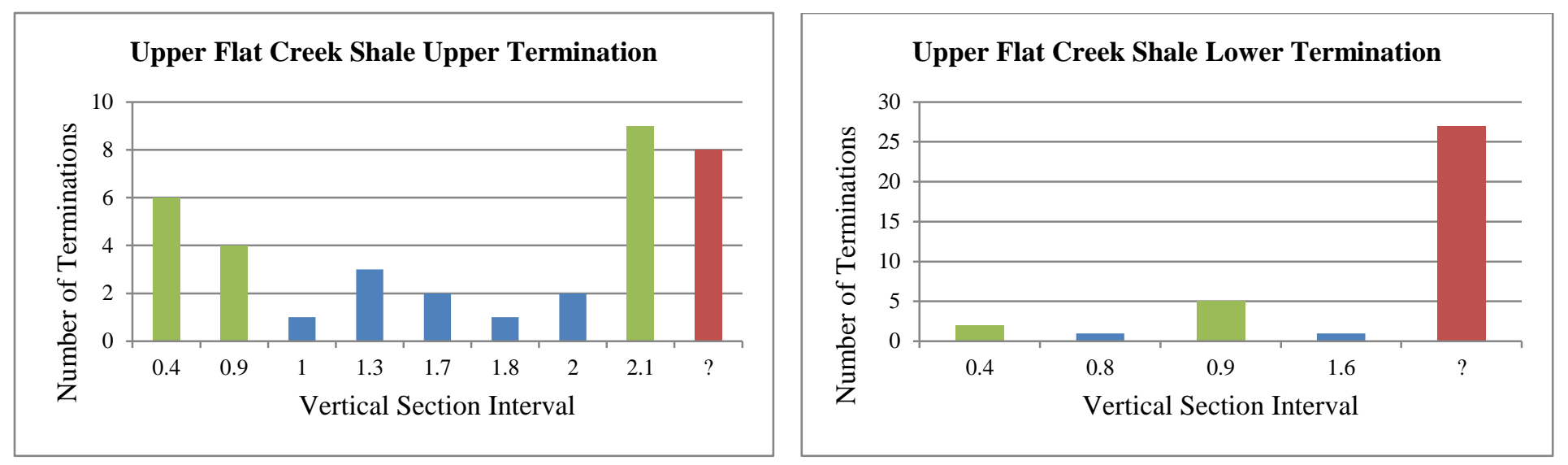

Figure 31: Count of upper and lower joint terminations by vertical interval in the Upper Flat Creek section. Bars are color coded by medium: green $=$ bentonite; blue $=$ shale; and red = unknown.

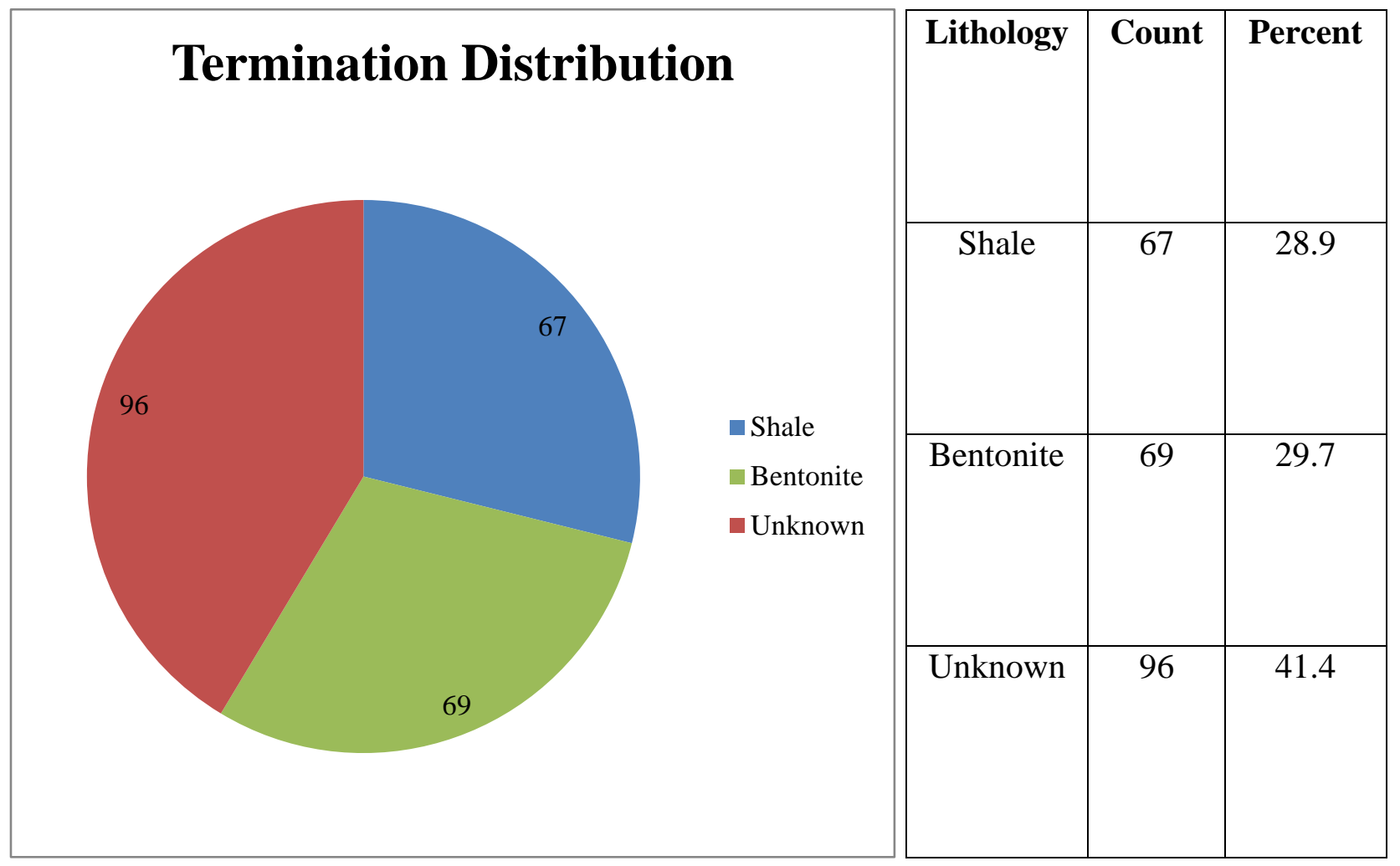

Figure 32: Count of terminations with respect to shale, bentonite, and unknown. The number of unknown terminations is high due to the weathered nature of these shale outcrops. The number of terminations in shale and in bentonites is similar, yet the bentonites are more mechanically significant because they account for a very small percentage $(\sim 2 \%)$ of the vertical section. 
The fracture bedding termination analysis has identified 136 vertical joint terminations in shale and bentonite layers. Bentonites are responsible for approximately $51 \%$ of identifiable fracture terminations in the Flat Creek Shale, while the remaining $49 \%$ of vein-filled fracture terminations occur in shale layers. There is only a slight majority of vertical terminations in bentonite layers, but these layers account for a limited portion of the total vertical section. The vertical thickness of the Lower (3.8 m), Middle (1.5 m), and Upper (2.1 m) Flat Creek sections combine for a total of 7.4 meters. There are eight bentonites in the Flat Creek sections that have a combined thickness of approximately $15 \mathrm{~cm}$. This cumulative thickness is based upon the thickness of the thick marker bentonite and the next seven deeper bentonites in Utica Core 74 NY-05. The outcrop bentonites are not used to determine this cumulative thickness estimation because they are more difficult to measure due to weathering, whereas the core provides a perfectly flat measurement surface. The combined thickness of the bentonites is $\sim 2 \%$ of the vertical section analyzed in the three Flat Creek sections.

The results of the fracture bedding termination analysis are statistically tested. The population of vertical joint terminations \& step-overs in shale is compared to the population of vertical joint terminations \& step-overs in bentonites using the z-score method. The z-score differentiates two populations by indicating how many standard deviations the mean of one population is from the mean of the "true population". This z-score analysis assumes that the vertical joint terminations \& step-overs in shale are the true population. The bentonites are mechanical interfaces if the population of vertical joint terminations \& step-overs in the bentonites is different from the true population. Z-score is calculated by the following equation:

$$
z=\frac{\left(\mu_{\text {bentonite }}-\mu_{\text {shale }}\right)}{\sigma_{\text {shale }} * \sqrt{1 / n_{\text {bentonite }}}}
$$


Where: $\mu_{\text {bentonite }}$ is the mean number of vertical joint terminations \& step-overs in the eight bentonite layers; $\mu_{\text {shale }}$ is the mean number of vertical joint terminations \& step-overs in the 31 shale layers; $\sigma_{\text {shale }}$ is the standard deviation of vertical joint terminations \& step-overs in the 31 shale layers; and $n_{\text {bentonite }}$ is the number of bentonite layers. This equation yields a z-score of 12.9 , indicating that there is greater than $99.9 \%$ probability that the bentonite layers are mechanically significant.

\begin{tabular}{|c|c|c|}
\hline & Bentonites & Shales \\
\hline Mean & 10.9 & 2.2 \\
\hline Standard Deviation & 5.8 & 1.9 \\
\hline $\mathbf{n}$ & 8 & 31 \\
\hline Z-Score & $\mathbf{1 2 . 9}$ \\
\hline
\end{tabular}

Data Table 3: Vertical joint terminations \& step-overs data used for calculating the z-score of the bentonite joint terminations \& step-overs population.

Mechanical interfaces that are composed of shale are less common. Three shale intervals exhibit relatively greater numbers of vertical joint terminations \& step-overs: the 1 meter mark (6 terminations \& step-overs) and 1.4 meter mark (8 terminations \& step-overs) of the Lower Flat Creek section and the .4 meter mark ( 8 terminations \& step-overs) of the Mid Flat Creek section. These three intervals are compared with the remaining 28 shale intervals with joint terminations \& step-overs using the same methodology as the comparison between vertical joint terminations \& step-overs in bentonites and shales. The resulting z-score is 10.8 , indicating that there is greater than $99.9 \%$ probability that these layers are mechanically significant.

The behavior of the joints that come in contact with a bentonite layer is explored. There are three potential outcomes when a joint interacts with a mechanical interface: termination, stepover, or cross-cutting (Cooke \& Underwood 2000). The joints in outcrops of the Utica Shale are 
observed to terminate, step-over, and cross-cut bentonite layers. The majority of the joints that come in contact with a bentonite are observed to terminate, while only $\sim 37 \%$ of joints cross-cut or step-over (Figure 34). The mean aperture of the joints that terminate at bentonites is $\sim .36 \mathrm{~mm}$; the mean aperture of the joints that step-over at bentonites is $\sim 2.82 \mathrm{~mm}$; and the mean aperture of the joints that cross-cut the bentonites is $\sim 1.59 \mathrm{~mm}$. These mean aperture values are calculated assuming that the veins that are too thin to measure in the field have an aperture of $.01 \mathrm{~mm}$. The mean aperture of joints that terminate at bentonites is lower because $\sim 90 \%$ of these joint apertures are too small to be measured in the field. Only $~ 47 \%$ of joints that step-over at bentonites, and $\sim 63 \%$ of joints that cross-cut bentonites, are too small to be measured in the field. The mean aperture values may be unreliable, but the data suggests a relationship between joint aperture and bentonite interaction: joints with greater apertures are more likely to cross-cut or step-over at a bentonite than they are to terminate at a bentonite.



Figure 34: There are three potential outcomes when a joint interacts with a bentonite: termination, step-over, or cross-cutting. The majority of joints terminate at a bentonite. This comparison only accounts for vein filled fractures. 


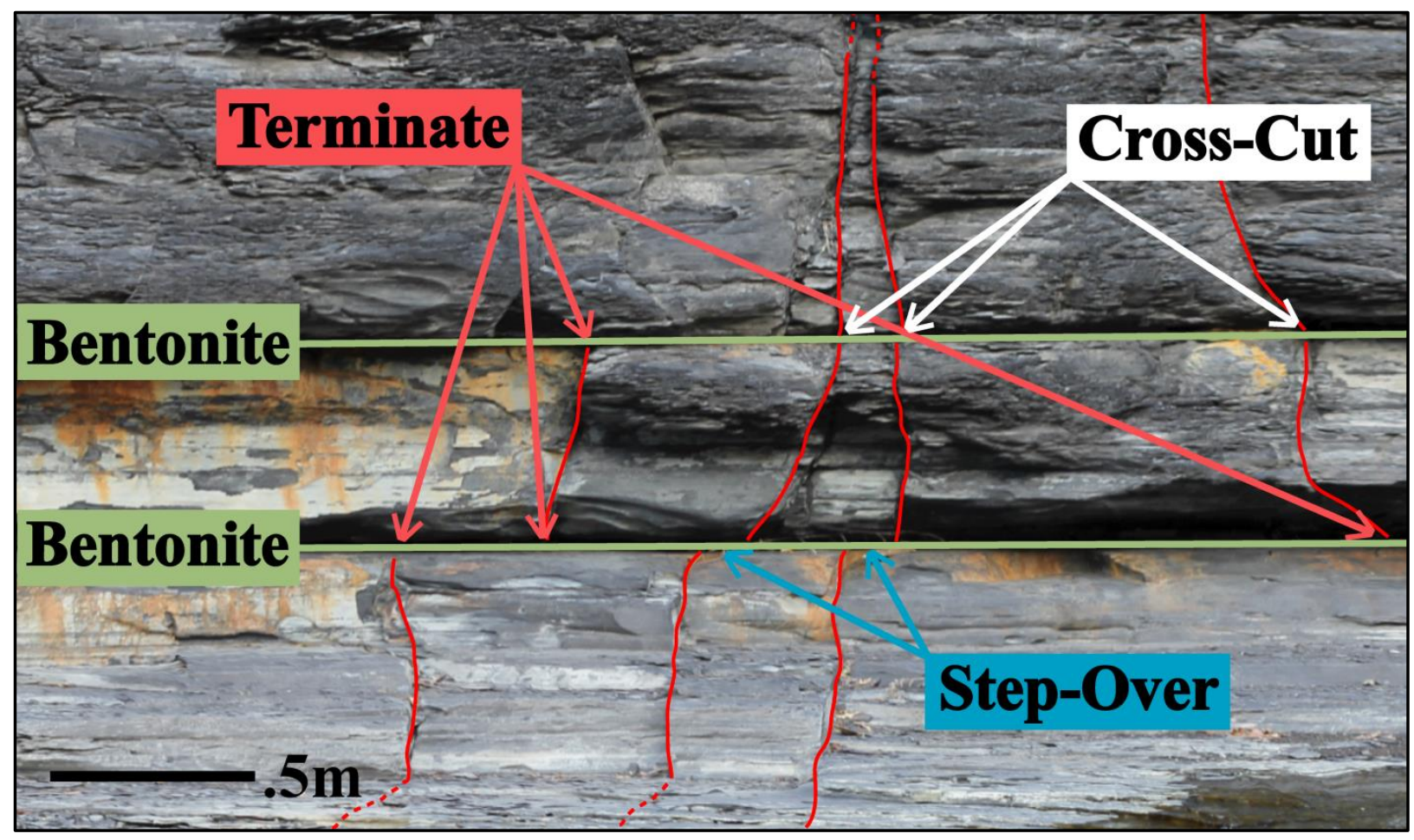

Figure 35: Joint interaction with bentonites. Photograph is from the Upper Flat Creek section. Joints are traced in red. There are joints with very small apertures present at this specific location, but they are not visible in this image and are not traced. These joints are relatively planar features, but they appear rugose because the outcrop face is irregular. The bentonites are sunken into the outcrop face due to preferential weathering of bentonites. The bentonites are also responsible for the brownish orange staining on the outcrop face.

A Schmidt Hammer is used to collect rock strength measurements from each of the outcrops studied on Flat Creek and Canajoharie Creek. The orientation of the Schmidt Hammer during rock strength measurement is not observed to cause variation in the results. Aditionally, the rock strength values retrieved from Canajoharie Creek and Flat Creek are similar. Shale and detrital carbonate Schmidt Hammer Q-values range between 23.1 and 76.7, while the bentonite Q-values are much lower between 14.8 and 35.4. The shale and bentonite Schmidt Hammer readings are differentiated in figure 41 . The rock strength values are missing for three of the eight bentonites because these layers are too thin and too far recessed from the outcrop face to be 
measured. These missing values are assigned the mean of the other five bentonites and are plotted amongst all of the rock strength and termination data in figure 37.

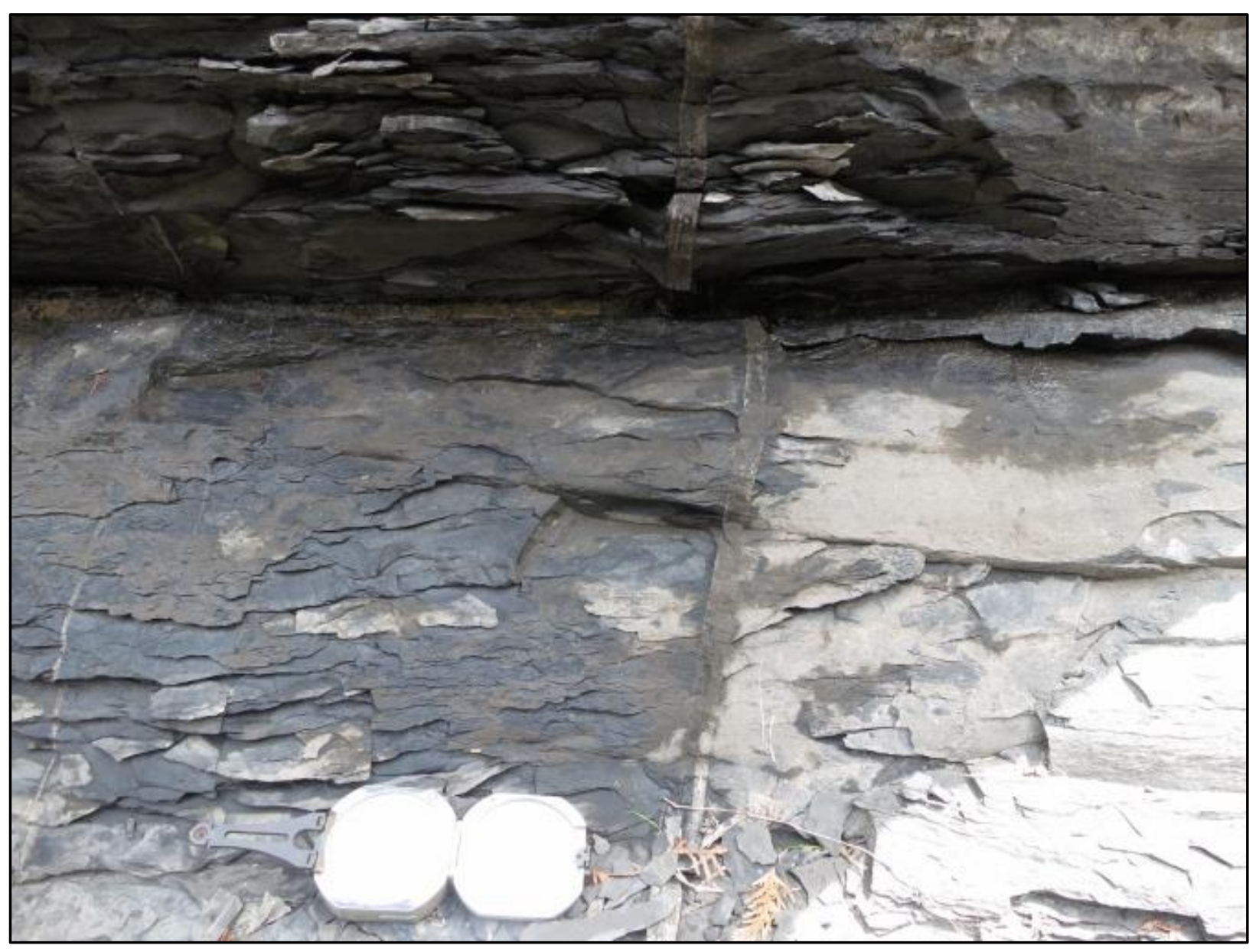

Figure 36: Step-over of vein-filled fracture at bentonite. This step-over is located at the Mid Flat Creek section. Brunton Compass for scale. 


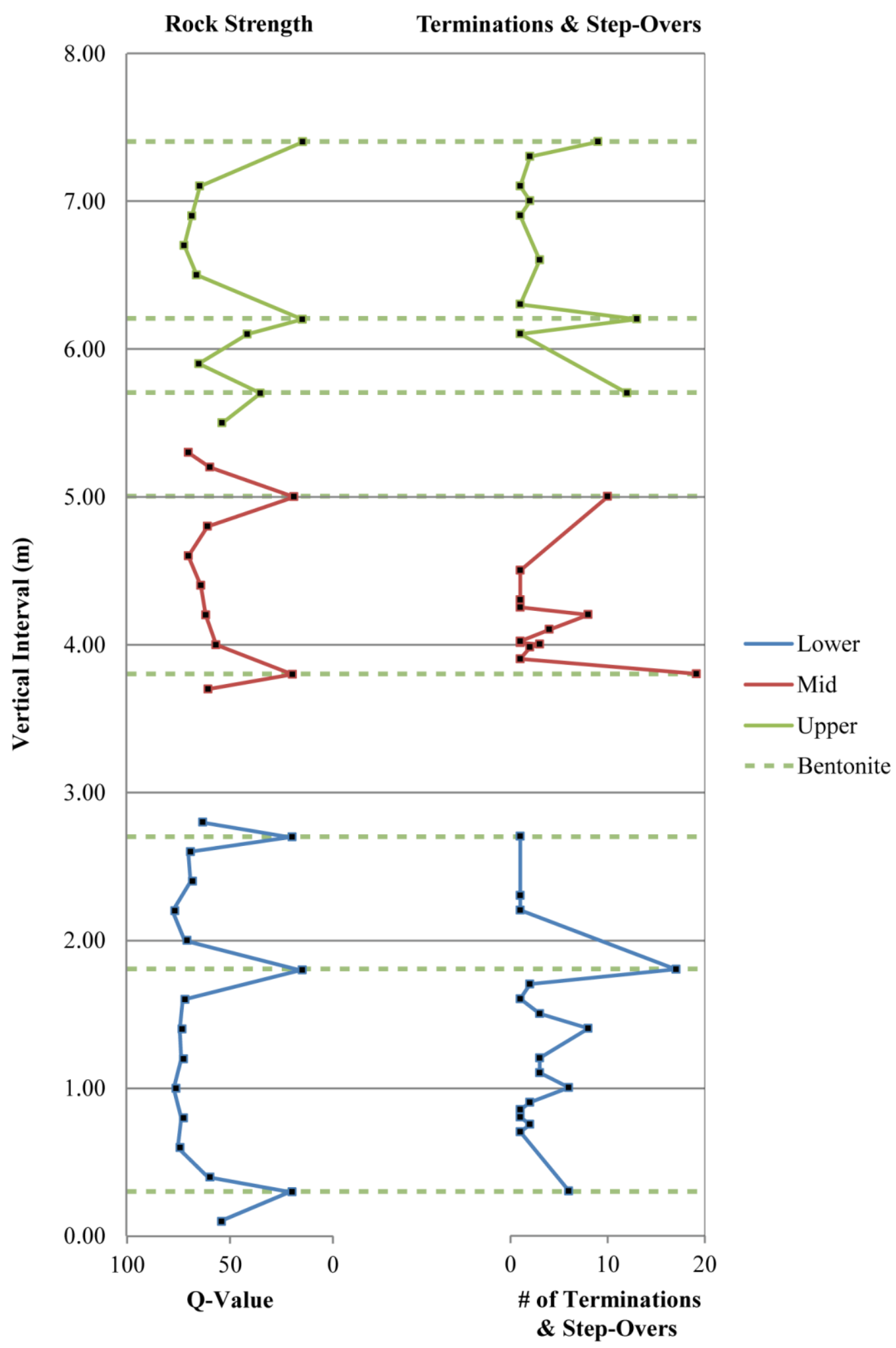

Figure 37: The Lower, Mid, and Upper section Schmidt Hammer rock strength Q-values and joint terminations \& step-overs are plotted by vertical interval. The bentonite rock strength values at $0.3 \mathrm{~m}, 2.7 \mathrm{~m}$, and $3.8 \mathrm{~m}$ are the mean of the five other bentonite rock strengths $(\mathrm{Q}=$ 19.8). 


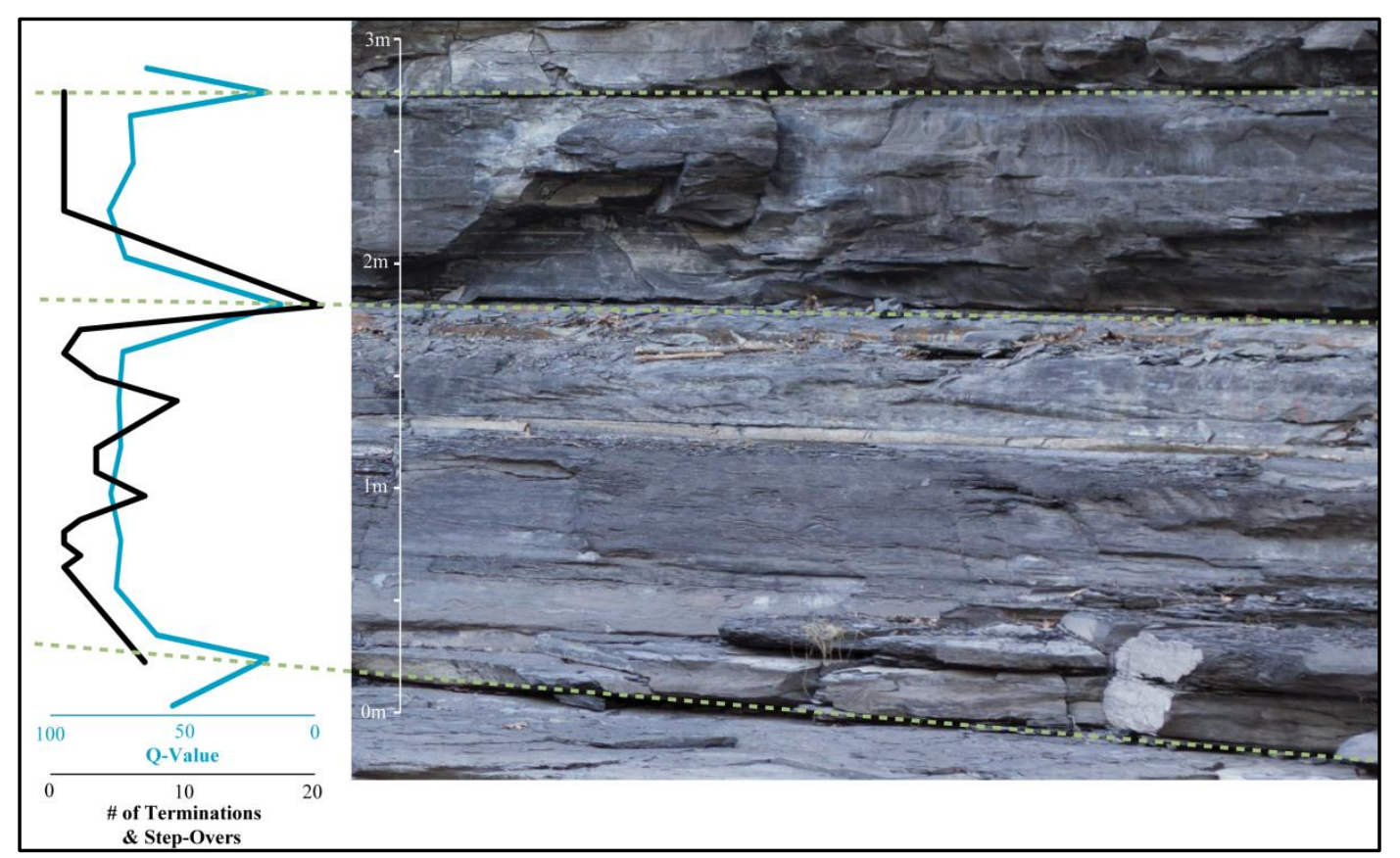

Figure 38: Lower Flat Creek section rock strength profile. Greater numbers of terminations \& step-overs occur at both low Q-values (bentonites) and higher Q-values (shales). The bentonites are marked by the dashed green lines. One of the terminations \& step-overs peak appears to correspond to a rock bed with lighter color and greater thickness.

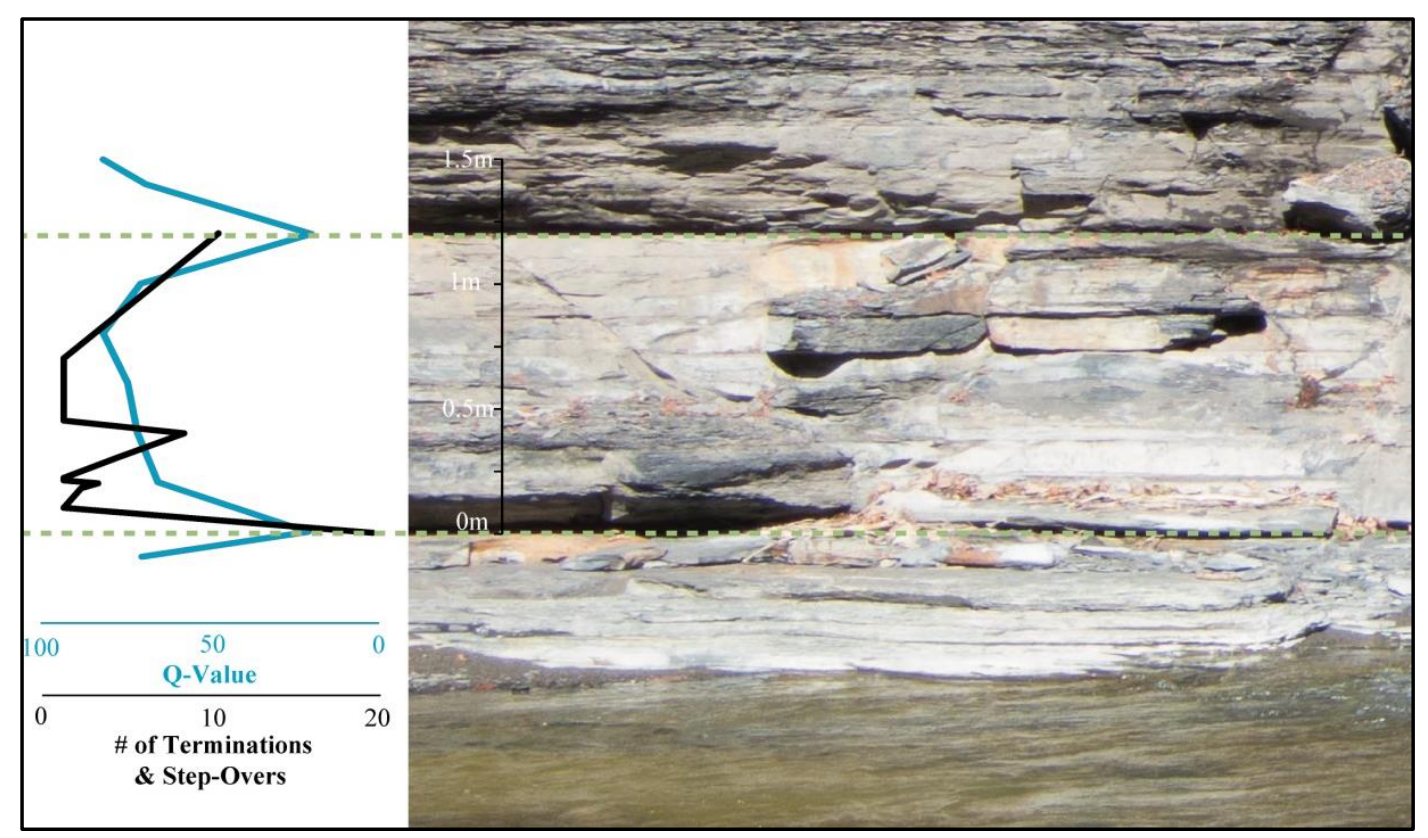

Figure 39: Lower Flat Creek section rock strength profile. Greater numbers of terminations \& step-overs occur at both low Q-values (bentonites) and higher Q-values (shales). The bentonites are marked by the dashed green lines. 




Figure 40: Upper Flat Creek section rock strength profile. The vast majority of the terminations and step-overs are accounted for by the bentonites at this location. There are no observed shale mechanical interfaces.

The weathering of the outcrops mimics the rock strength profile, as well as the terminations \& step-overs profile to a lesser extent. The bentonites are the most apparent visual contrast in the vertical sections. The 1.4 meter mark of the Lower Flat Creek Section terminations \& step-overs profile matches well with what appears to be a detrital carbonate-rich bed. This bed is interpreted to be detrital carbonate-rich because it has a lighter color and is relatively thick. The other shale mechanical interfaces cannot be visually identified in the outcrop photographs. The rock strength values and the weathering profile suggest that the present day mechanical properties of the bentonites are very different than those of the shale beds. The fracture stratigraphy suggests that the bentonites were also mechanically significant while joints were propagating. 


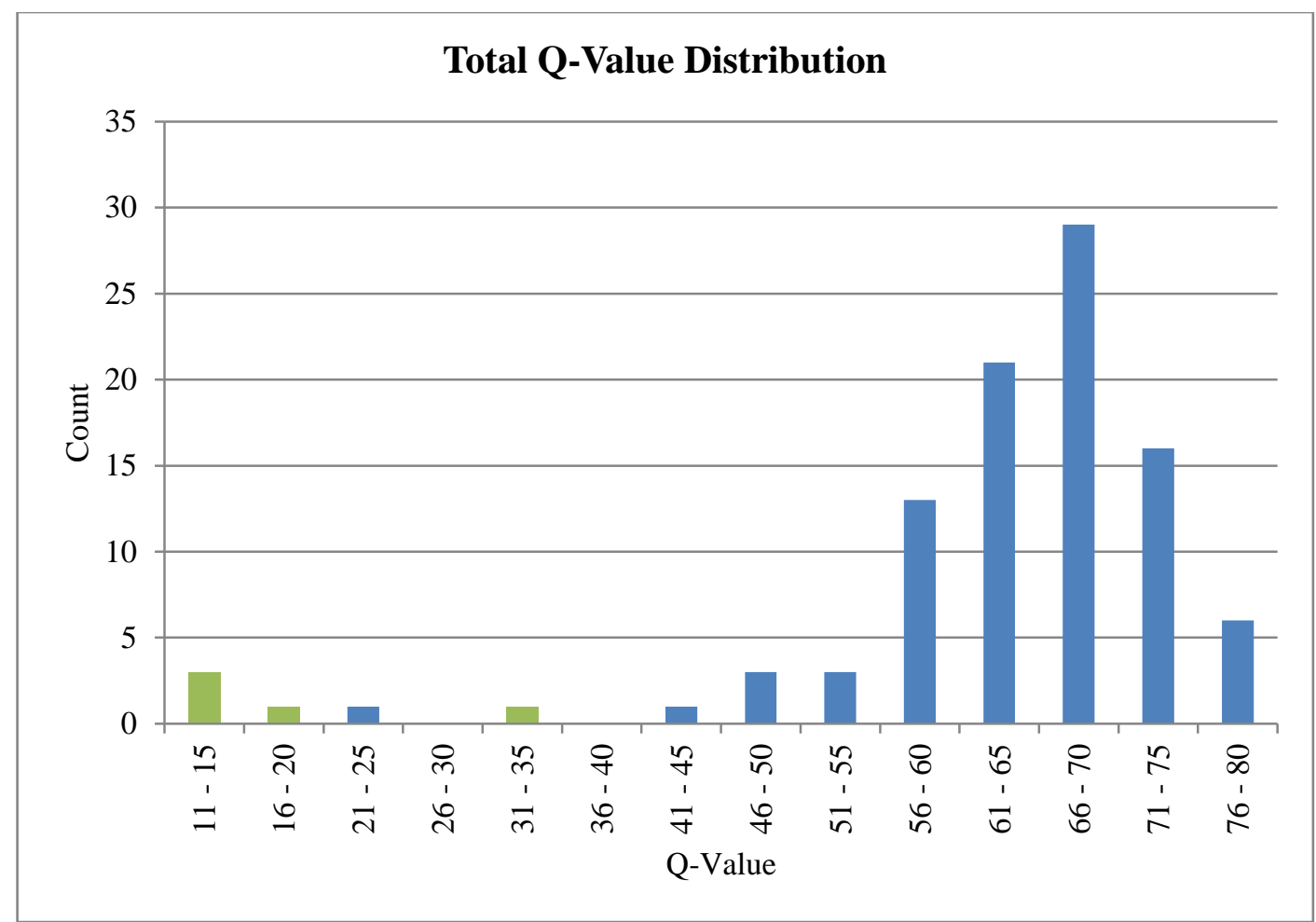

Figure 41: Total Schmidt Hammer rock strength data including vertical and horizontal measurements. Bentonite rock strength measurements are shaded in green, while shale rock strength measurements are shaded blue.

\subsection{XRD Results}

Shale and bentonite samples from outcrops of the Utica Shale are analyzed with a PANalytical X'Pert PRO XRD. The objective of the XRD analysis is to identify the dominant mineral assemblages in the shales and bentonites to determine how composition influences mechanical properties and fracture propagation. The diffractograms of the shale and bentonite samples are easily distinguishable, because the $2 \theta$ peaks of each lithology vary by location and intensity, indicating that the shales and bentonites are compositionally dissimilar (Figure 41); whereas the shale samples contain nearly identical mineralogical components, if not in the same proportions (Figure 42). There are minor amounts of minerals in each sample that could not be identified because elemental composition is not constrained. Regardless, the XRD analysis has determined that the shales in the Utica Shale are primarily composed of quartz and carbonate material, and the bentonites mostly consist of authigenic clays. 




Figure 42: Combined diffractograms of all samples collected from the Flat Creek Shale on Flat Creek. The lower cluster of diffractograms consists of shale samples, and the upper group consists of bentonites.

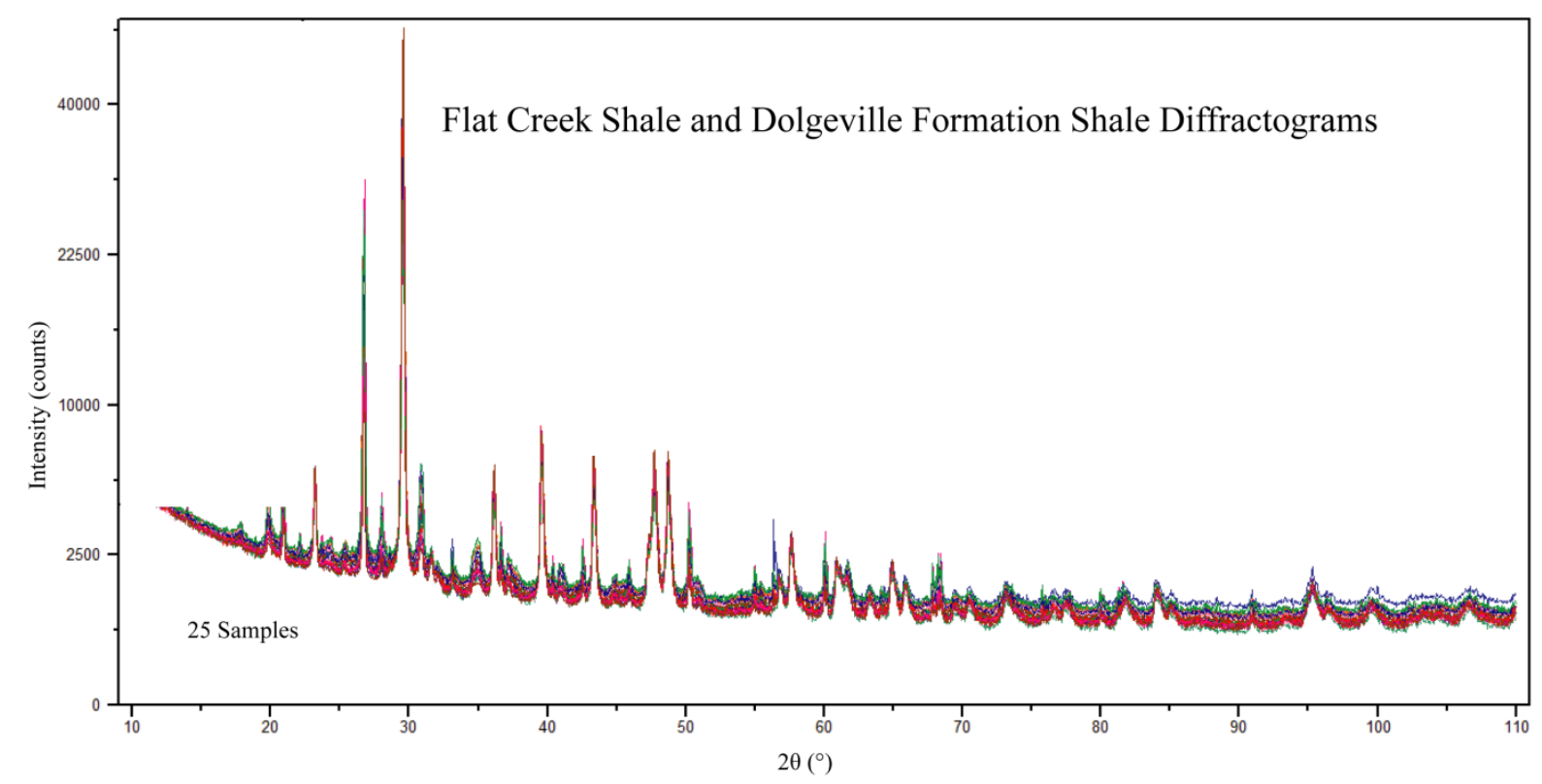

Figure 43: Combined diffractograms of the 25 shale samples collected on Flat Creek. The diffractograms suggest that the shale samples are consistently composed of similar material. 


\begin{tabular}{|c|c|c|c|c|c|c|c|c|c|}
\hline Sample & Lithology & Calcite & Quartz & Dolomite & Pyrite & Illite & Kaolinite & Gypsum & Jarosite \\
\hline FC1 & Shale & 59 & 34 & 7 & 0 & 0 & 0 & 0 & 0 \\
\hline FC2 & Bentonite & 0 & 15.2 & 0 & 0 & 51.5 & 8.1 & 15.2 & 10.1 \\
\hline FC3 & Shale & 62 & 32 & 6 & 0 & 0 & 0 & 0 & 0 \\
\hline FC4 & Bentonite & 3 & 12.1 & 0 & 2 & 61.6 & 21.2 & 0 & 0 \\
\hline FC5 & Shale & 60 & 33 & 7 & 0 & 0 & 0 & 0 & 0 \\
\hline FC6 & Bentonite & 10 & 19 & 0 & 2 & 48 & 21 & 0 & 0 \\
\hline FC7 & Shale & 54 & 36 & 10 & 0 & 0 & 0 & 0 & 0 \\
\hline FC8 & Bentonite & 3 & 12 & 0 & 12 & 48 & 15 & 5 & 5 \\
\hline FC9 & Shale & 66.3 & 28.7 & 5 & 0 & 0 & 0 & 0 & 0 \\
\hline FC10 & Bentonite & 26 & 10 & 0 & 13 & 37 & 14 & 0 & 0 \\
\hline FC11 & Shale & 55 & 34 & 11 & 0 & 0 & 0 & 0 & 0 \\
\hline FC13 & Shale & 48.5 & 45.5 & 5.9 & 0 & 0 & 0 & 0 & 0 \\
\hline FC14 & Bentonite & 6.1 & 25.3 & 0 & 9.1 & 43.4 & 13.1 & 3 & 0 \\
\hline FC15 & Shale & 57 & 34 & 9 & 0 & 0 & 0 & 0 & 0 \\
\hline FC16 & Bentonite & 8 & 15 & 0 & 6 & 34 & 6 & 18 & 13 \\
\hline FC17 & Shale & 55 & 39 & 6 & 0 & 0 & 0 & 0 & 0 \\
\hline FC18 & Bentonite & 5.9 & 18.8 & 0 & 2 & 56.4 & 11.9 & 5 & 0 \\
\hline DV1 & Shale & 56 & 31 & 10 & 3 & 0 & 0 & 0 & 0 \\
\hline DV2 & Shale & 51 & 33 & 16 & 0 & 0 & 0 & 0 & 0 \\
\hline DV3 & Shale & 43 & 40 & 15 & 2 & 0 & 0 & 0 & 0 \\
\hline DV4 & Shale & 46 & 41 & 13 & 0 & 0 & 0 & 0 & 0 \\
\hline DV5 & Shale & 74 & 19 & 7 & 0 & 0 & 0 & 0 & 0 \\
\hline DV6 & Shale & 79 & 16 & 5 & 0 & 0 & 0 & 0 & 0 \\
\hline DV7 & Shale & 47 & 37 & 16 & 0 & 0 & 0 & 0 & 0 \\
\hline DV8 & Shale & 44 & 41 & 15 & 0 & 0 & 0 & 0 & 0 \\
\hline DV9 & Shale & 71 & 23 & 6 & 0 & 0 & 0 & 0 & 0 \\
\hline DV10 & Shale & 86 & 12 & 2 & 0 & 0 & 0 & 0 & 0 \\
\hline DV11 & Shale & 51 & 38 & 11 & 0 & 0 & 0 & 0 & 0 \\
\hline DV12 & Shale & 68 & 22 & 7 & 3 & 0 & 0 & 0 & 0 \\
\hline DV13 & Shale & 43 & 42 & 15 & 0 & 0 & 0 & 0 & 0 \\
\hline DV14 & Shale & 48 & 43 & 9 & 0 & 0 & 0 & 0 & 0 \\
\hline DV15 & Shale & 56 & 32 & 12 & 0 & 0 & 0 & 0 & 0 \\
\hline DV16 & Shale & 76 & 19 & 5 & 0 & 0 & 0 & 0 & 0 \\
\hline W10 & Shale & 41 & 47 & 12 & 0 & 0 & 0 & 0 & 0 \\
\hline W28 & Shale & 54 & 39 & 7 & 0 & 0 & 0 & 0 & 0 \\
\hline W29 & Shale & 83 & 12 & 2 & 3 & 0 & 0 & 0 & 0 \\
\hline W40 & Shale & 87 & 10.9 & 0 & 2 & 0 & 0 & 0 & 0 \\
\hline
\end{tabular}

Data Table 4: Percent mineral composition of all samples, derived from X-ray diffraction. Flat Creek samples are prefaced with FC; Dolgeville samples are prefaced with DV; and Canajoharie Creek samples are prefaced with W (for Wintergreen Park). FC12 was never collected. 


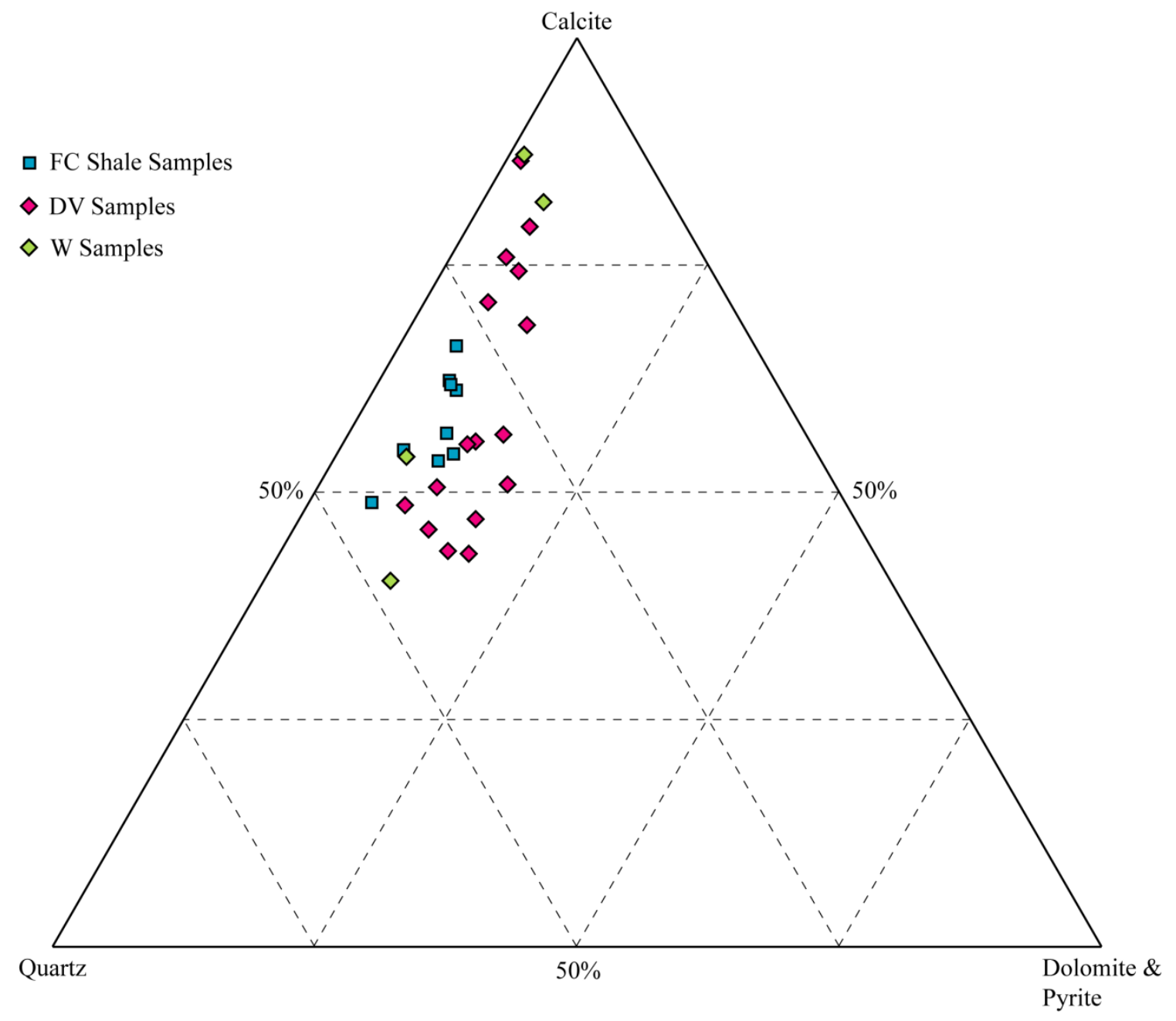

Figure 44: Ternary diagram of the all shale samples from Flat Creek and Canajoharie Creek.

The shale samples are mostly composed of calcite and quartz, while the bentonites are composed of varying amounts of quartz, calcite, illite, kaolinite, gypsum, and jarosite, with illite being the dominant mineral in each of the bentonite samples (Data Table 4). Shale samples from the Flat Creek Shale contain minor amounts of dolomite, and the Dolgeville Formation samples contain minor amounts of dolomite and pyrite. According to the XRD data, all of the shale samples are either calcilutites ( $~ 50 \%$ detrital carbonate) or calcisiltites (predominantly detrital carbonate). Some of the Dolgeville Formation samples have greater amounts of detrital calcite than the samples of shale from the Flat Creek Shale (Figure 44). The Dolgeville Formation samples with increased calcite are 
calcisiltites, and the samples with less detrital carbonate are calcilutites (or potentially organicrich shales depending on the accuracy of the XRD data). The dolomite component in these samples is assumed to be detrital in origin based upon thin section observations. The detrital carbonate-rich Wintergreen Park samples are collected from the lowermost Dolgeville Formation, and the detrital carbonate-lean samples are collected from the uppermost Flat Creek Shale. The shale samples from Flat Creek lack authigenic minerals entirely (Figure 45). Each of the bentonite samples from Flat Creek consist of at least 64\% authigenic minerals (Figure 45).



Figure 45: Ternary diagram of all Flat Creek samples. Ternary diagram end-members are quartz, detrital carbonates, and authigenic minerals (mostly clay minerals). 


\section{Discussion}

A bedding unit is defined as a mechanical interface when a significant number of fracture tips terminate at its boundary (Underwood 2003). The bentonites in the Utica Shale are considered mechanical interfaces because joints preferentially terminate at these layers. Bentonites are mechanically significant because their compositions, and subsequently their mechanical properties, are very different from the packages of shales and detrital carbonates (Narr \& Suppe 1991). The bentonites in the Utica Shale are composed of potassium-rich, diagenetically altered, quenched, silicic magmas (Goldman et al. 1994). The original composition of the volcanic ash is unknown, but melt inclusions in phenocrysts of quartz, zircon, and apatite are composed of rhyolitic glass (Goldman et al. 1994; Delano et al. 1994). The Schmidt Hammer rock strength values of the bentonites are consistently less than the rock strength values of the shales, but clay minerals, specifically illite and kaolinite, may be influencing the present day rock strengths of the bentonites. The bentonites have been altered from volcanic ash beds into authigenic minerals since initial deposition (Goldman et al. 1994; Delano et al. 1994). Therefore, the Schmidt Hammer Q-values may be under-representative of the strength of the volcanic ashes during the period of time in which joints were propagating. The bentonites may also have always been different than the shale beds in terms of mechanical properties, regardless of diagenetic alteration. The timing of diagenetic alteration is unknown, but the observed fracture stratigraphy suggests that the bentonites were mechanically significant in the subsurface during the period of time in which joints were propagating.

The 1 meter mark and 1.4 meter mark of the Lower Flat Creek section and the .4 vertical meter mark of the Mid Flat Creek section are the most apparent shale mechanical interfaces. These intervals were not recognized as mechanical interfaces during the fracture bedding 
termination analysis, and samples were not collected. These intervals were measured by the Schmidt Hammer and exhibited rock strength values of 76.2, 73.2, and 61.9, respectively. The mean Q-value of shales on Flat Creek is 64.97. Additional shale mechanical interfaces would be apparent if this difference in measured rock strengths is significant. Preferential termination at these three intervals indicates that shale mechanical interfaces are present within the Utica Shale, but not enough properties have been constrained to make an interpretation about the specific cause of fracture termination.

Density of the E-W $\left(280^{\circ}\right)$ joint set is observed to decrease in the Upper portions of the Flat Creek Shale and the Dolgeville Formation at both field locations. The reduced joint density in the Dolgeville Formation may be dependent on the origin of the vein-filled joints. One potential origin of joints in the Utica Shale is depicted in figure 47, and is derived from previous interpretations of Taconic-aged, basement structure-related, and dolomitized veins in the underlying Trenton-Black River Formation (Figure 46; Beardsley 1999). In the model in figure 47, the reduced joint density in the Dolgeville Formation results because some joints present in the Trenton-Black River Formation fail to vertically propagate through the bentonites in the Flat Creek Shale. This theory is problematic because basal terminations are observed in outcrop, suggesting some joint origins in the Flat Creek Shale. However, there are many calcite veinfilled fractures that extend into the subsurface, so some of the joints may be associated with faulting in the underlying strata. An investigation of mineral assemblages in the vein-filled joints of the Utica Shale in this field location may reveal the presence of dolomite precipitation, indicating that some joint sets are unequivocally Taconic-aged and are related to basement structures. 




Figure 46: Cross section of the Glodes Road Discovery Field. Modeled relationship between hydrothermal dolomites of the Black River Group and the overlying Trenton Group. The fractures originating in the Black River Group may have propagated up into the overlying Utica Shale. Modified from Beardsley (1999) and retrieved via Agle (2008).

A second joint origin theory is modeled in figure 48. This theory postulates that joints in the Utica Shale formed because of increasing pore fluid pressures, resulting from hydrocarbon maturation. Increased pore fluid pressure can be produced by multiple mechanisms, including: disequilibrium compaction, lateral compressive stress, aquathermal expansion, smectite dehydration, smectite to illite transformation, kerogen transformation and gas generation, chemical compaction, osmosis, hydrocarbon buoyancy, and hydraulic head (English 2012). Hydrocarbon maturation is interpreted to have had some role in increasing pore fluid pressures in the Utica Shale because this formation produces dry gas to the south in Pennsylvania and elsewhere. The Flat Creek Shale is interpreted to exhibit greater joint density than the Dolgeville Formation because it hosts greater amounts of organic carbon. TOC data is retrieved from the 
work on Utica Core 74 NY-05 by Gordon Baird (appendix H; Smith et al. 2013). An increased proportion of detrital carbonate material is interpreted to dilute TOC in the Dolgeville Formation, thereby reducing the overall percent composition. This model also incorporates the effect of bentonites on joint density: some of the joints originating in the Flat Creek Shale may have propagated into the Dolgeville Formation had the bentonites not been present. The reduced density in the Dolgeville Formation may be the combined product of lower TOC and joint terminations at bentonites.

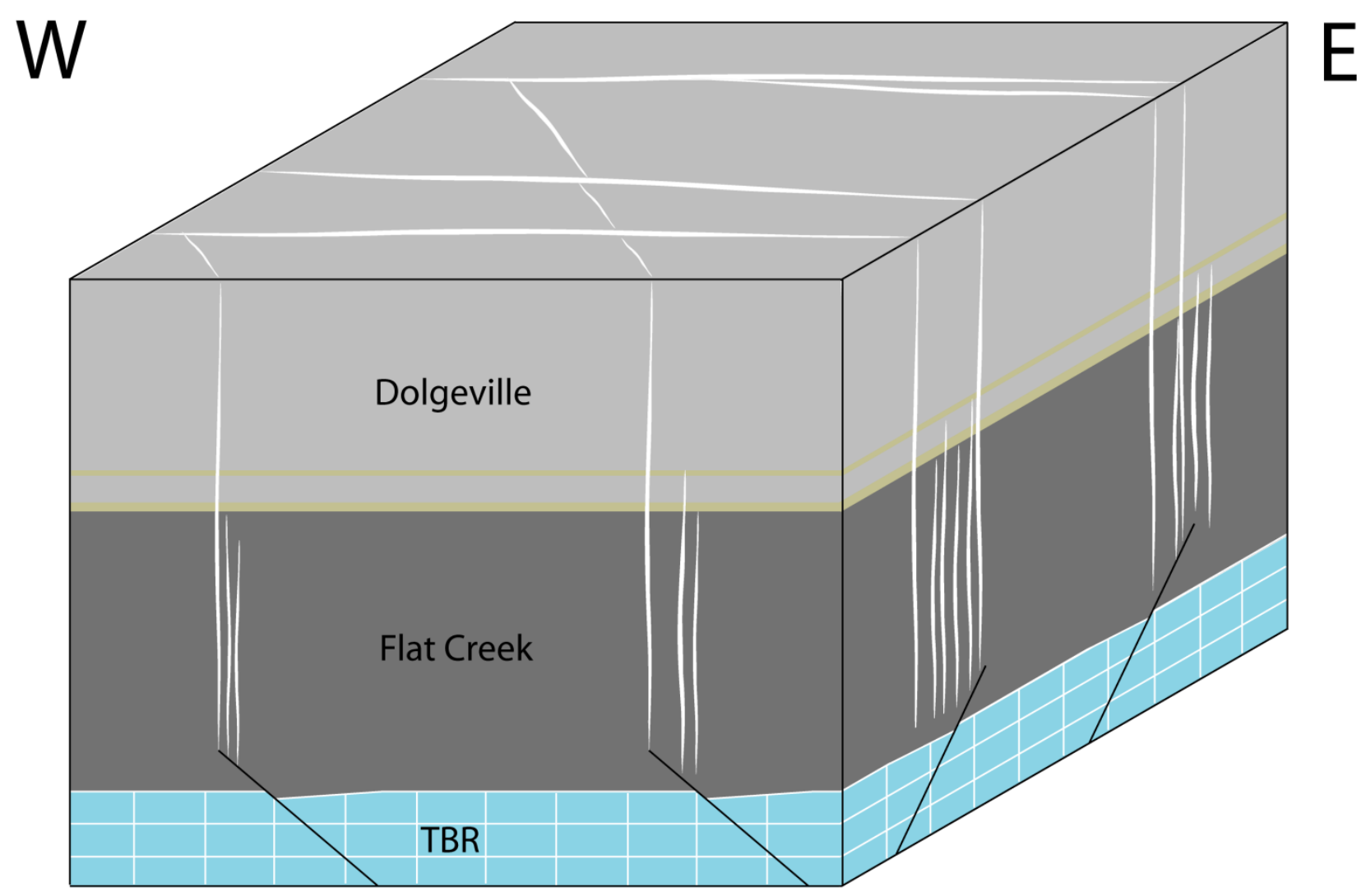

Figure 47: Trenton-Black River fracture origination model. This model postulates that the approximately E-W ( $280^{\circ}$ striking) vein-filled fractures found in the Flat Creek and Dolgeville Formation originate from the faults in the Trenton-Black River. Vein-filled fractures display a swarming tendency in this model. The vein-filled fracture density is lower in the Dolgeville Formation because the veins terminate at bentonites while propagating upwards through the section. Bentonites are represented by the brownish-yellow layers. Joints with greater apertures are more likely to cross-cut the bentonites. 


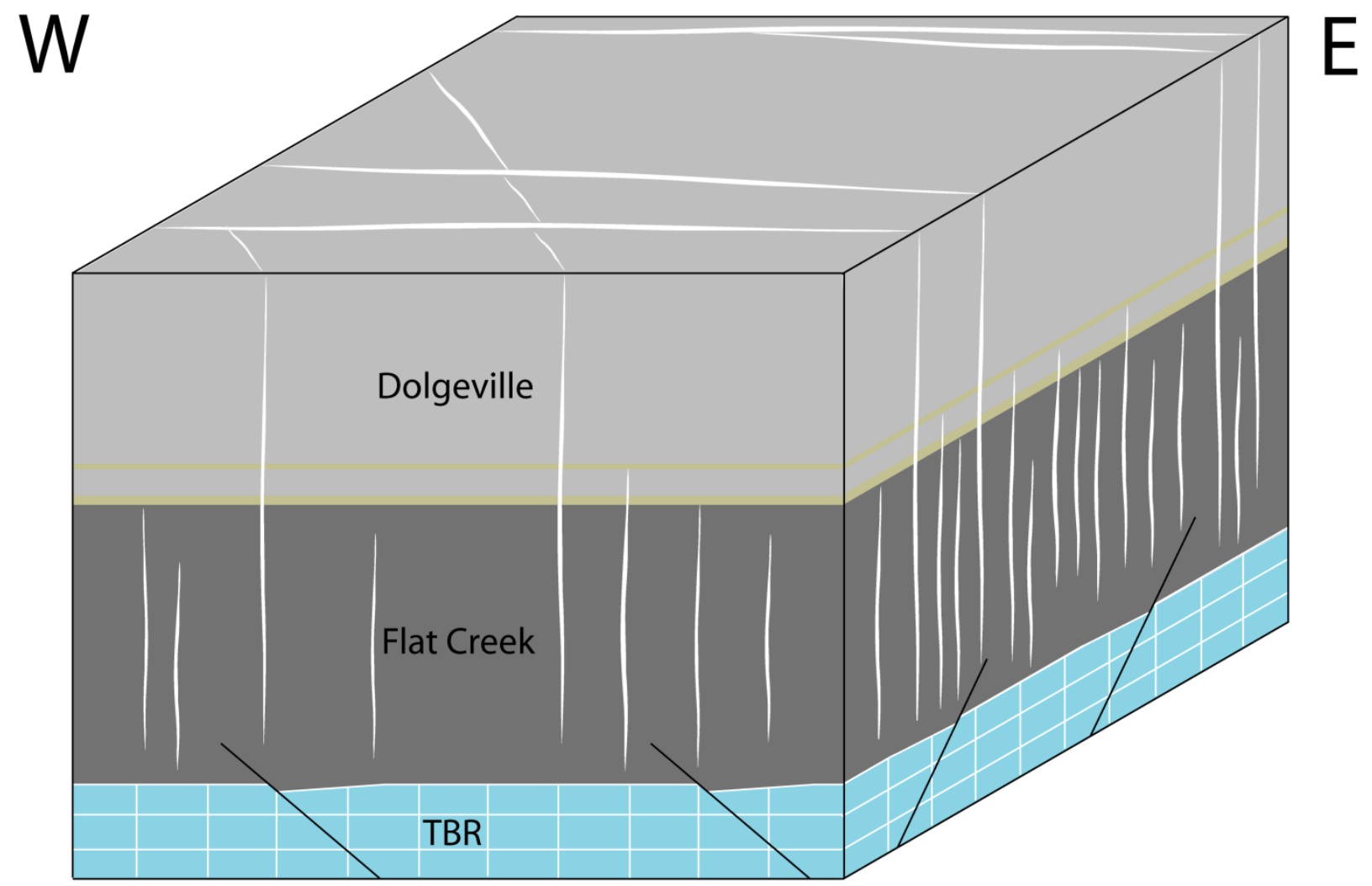

Figure 48: Flat Creek hydrocarbon maturation fracture origination model. This model posits that the majority of fractures in the Utica Shale are the product of increased pore fluid pressures resulting from the maturation of hydrocarbons. While fractures still terminate at bentonites, the TOC-poor detrital carbonate lithofacies of the Dolgeville Formation are the primary reason for decreased fracture density. Joints are more evenly spaced in this model. Joints with greater apertures are more likely to cross-cut the bentonites. Bentonites are represented by the brownish-yellow layers.

The cause of the observed joint density variability in the vertical section is not entirely resolved by this study. The processes outlined in figures 47 and 48 may be contributing to the formation of joints in the Utica Shale, but the relative importance of each remains unknown. The joint density variability may also be related to the lithologic properties of shales in each formation. There are a greater proportion of calcisiltite and calcilutite beds in the Dolgeville Formation than there are in the Flat Creek Shale. The sedimentary texture of the organic-rich shales is interpreted to have limited influence on fracture termination, because there is less 
contrast between detrital carbonate-rich and detrital carbonate-lean zones than there is in the calcilutite lithofacies. The sedimentary texture of the calcilutites and calcisiltites is interpreted to be more likely to have an influence on fracture termination. In the calcilutite lithofacies, the mechanical contrast of alternating detrital carbonate-rich and detrital carbonate-lean lamina may inhibit fracture propagation. The mechanical effect of ripple cross-laminae and soft sediment deformation in the calcilutite lithofacies is unknown. Ripple cross-laminae and soft sediment deformation may act as foci for fracture initiation, or as mechanical interfaces due to increased mechanical contrast. The calcisiltite lithofacies contains few, and relatively small, mechanical flaws; therefore, there are few sites for fracture initiation and preferential fracture propagation in this lithofacies. The vertical alternation between organic-rich shales and the other two lithofacies likely inhibits fracture propagation as well, because mechanical contrast between layers inhibits fracture propagation (Renshaw \& Pollard 1995). Therefore, the sedimentary textures of two of the dominant lithofacies, and the interbedded nature of these two lithofacies with organic-rich shale, are interpreted to be less conducive for fracturing in the Dolgeville Formation.

The rock strength data are not in agreement with the supposition that the mechanical properties of the detrital carbonate-rich beds are influencing fracture propagation. The rock strengths of the detrital carbonate-rich and detrital carbonate-lean lithologies are not differentiated by the Schmidt Hammer, as evidenced by only one peak in the Q-value data population (figure 41). However, the reduced number of vein-filled joints in the Dolgeville Formation, and the presence of shale mechanical interfaces, suggests that the mechanical properties of shales may be a contributing factor. Furthermore, the Schmidt Hammer data for these shales may be unreliable. It is unlikely that the Schmidt Hammer lacks the sensitivity to differentiate between the rock strength of detrital carbonate-lean and detrital carbonate-rich beds, 
rather the Schmidt Hammer methods are ineffective when the outcrops are too weathered to obtain accurate measurements. Some rock strength measurements are also likely confounded by layer-parallel partings between beds because individual layer parallel partings may convert the piston energy of the Schmidt Hammer to acoustic energy and vibration of the mechanical partings, thus decreasing Schmidt Q-values. The Schmidt Hammer method may be able to discern a difference between the rock strengths of detrital carbonate-rich and detrital carbonatelean lithologies in the Utica Shale if the outcrop being measured has been recently exposed.

Fracture abutment relationships have a major influence on the fracture patterns portrayed in the digital scan lines. The abutment relationships between fracture sets in the digital scan lines are derived from field observations, but the scan lines remain interpretations because lateral fracture lengths and lateral terminations are not often observed in the field, necessitating major assumptions. The primary purpose of the digital scan lines is to illustrate the spacing of the E-W joint set at each location. The spacing of this set provides some information about how the joints formed. If the joints are evenly spaced, they are more likely to be related to a regional fracturing event, whereas swarming joints are more likely to be related to faults and potentially the fracture system in the underlying Trenton-Black River Formation (Lorenz 1991). Regional joints propagate parallel to the plane of the maximum and intermediate compressive stress in deeply buried, overpressured strata remote from the active tectonic front (Lorenz et al. 1991). The scan lines suggest a combination of fault-related joints and regional joints based upon spacing alone. Most of the scan lines on Canajoharie Creek and Flat Creek show joints that are relatively evenly spaced, but the lower Flat Creek 1 scan line is an exception (Figure 21). A basement-faulting joint origin theory is not supported by field evidence because structures and faults are not observed on Flat Creek. However, rhombochasms at multiple locations are excellent evidence 
for a period of strike slip motion (Figure 49). The approximately NW-SE fractures are interpreted to be genetically related to strike-slip motion because they host the rhombochasms.

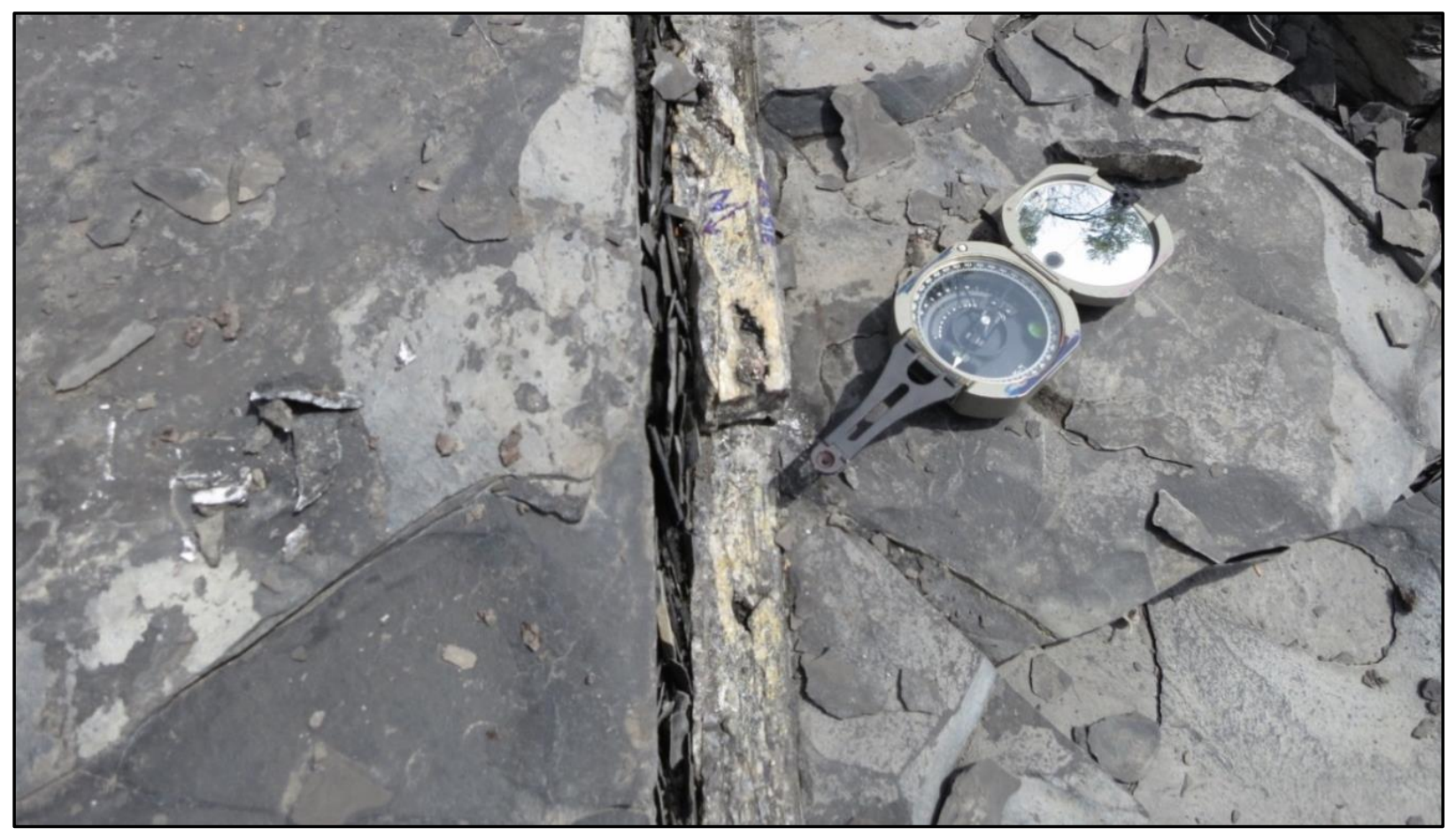

Figure 49: Mineral-filled rhombochasms in the Flat Creek Shale. The vein is oriented NW-SE. This set is interpreted to be genetically related to strike slip motion; the timing of strike slip motion is uncertain.

A relationship between bedding thickness and vein-filled joint density is not observed in outcrops of the Utica Shale in eastern New York State. The thickness of beds in outcrop is comparable to the thicknesses measured in Utica Core 74 NY-05, yet the beds do not consistently exhibit vein filled fractures every few centimeters, nor a vein-filled fracture to bedding thickness ratio near 1 (Bai \& Pollard 2000). The majority of the alternating detrital carbonate-rich beds and organic-rich beds are interpreted to act as single coherent mechanical units, mechanically separated by bentonites. This interpretation is consistent with the premise that the joints in the Utica Shale formed at significant depth, because increased overburden leads 
to increased frictional forces at bedding boundaries (Fisher \& Warpinski 2012). The closelyspaced, un-filled fractures observed in the Dolgeville Formation outcrops, that strike between $030^{\circ}$ and $045^{\circ}$, are interpreted to have formed at the surface or near surface because they are not present in Utica Core 74NY-05. There are also layer-parallel joints in the Dolgeville Formation outcrops that are additional evidence for near-surface fracturing (Figure 50). The layer parallel joints are interpreted to reduce friction at the interface between shale beds, separating individual beds into single mechanical units. This interpretation agrees with the qualitative observation of a strong relationship between bedding thickness and un-filled joint density in the Dolgeville Formation outcrop on Flat Creek (Figure 25).

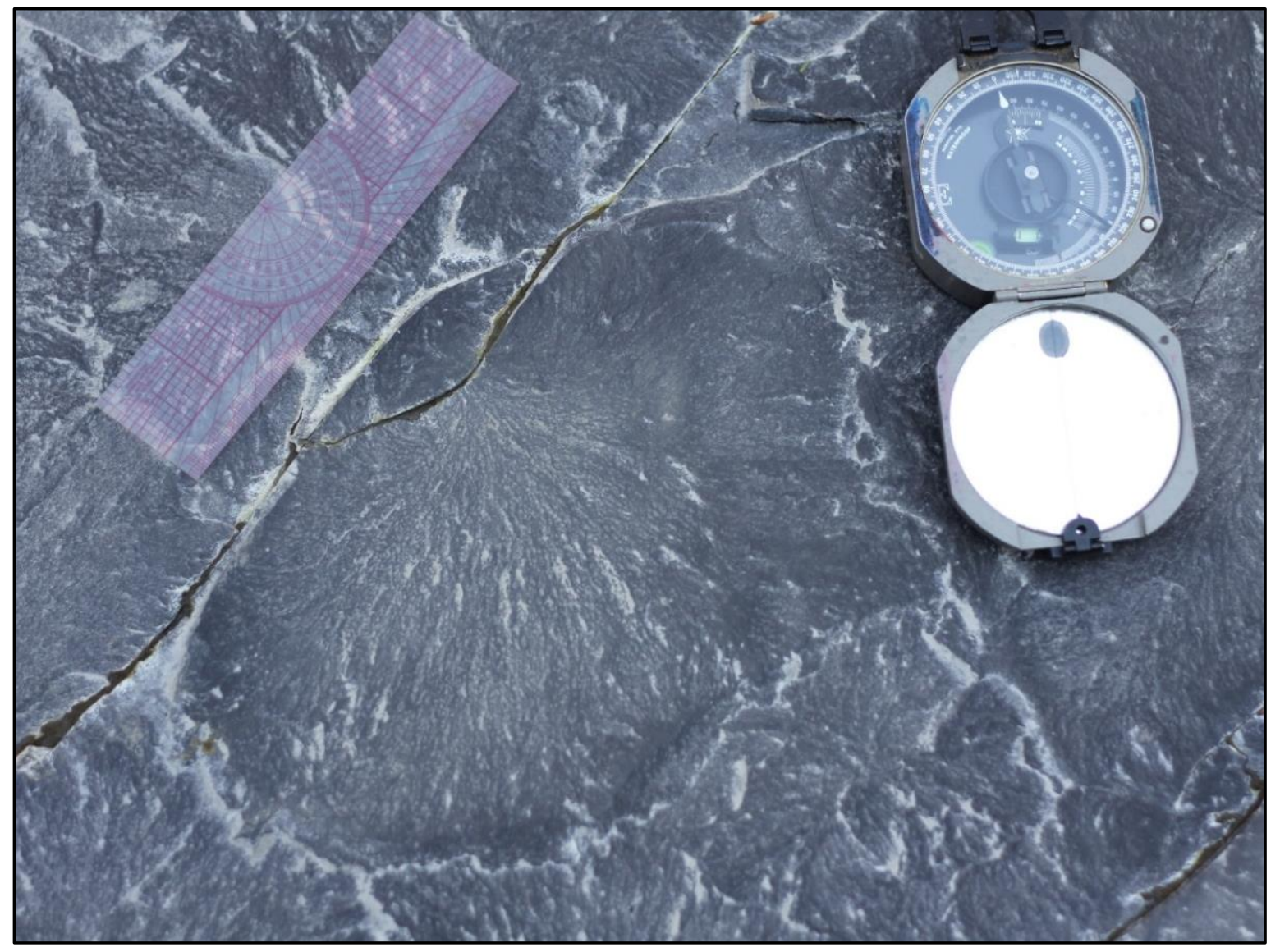

Figure 50: Layer-parallel fracture in the Dolgeville Formation. Fracture morphology is well preserved: fracture initiation point, plumose structure, and terminus are apparent. 
There are three fracture sets that are observed on Flat Creek: E-W joints with vein-fill, approximately NW-SE joints with vein-fill, and fractures without vein-fill that have a highly variable strike azimuth. One way to think about the origin of these three primary fracture types is in terms of in-situ stress in the subsurface through time. The E-W joint set is interpreted to have developed at a peak burial depth near 10,000 feet as hydrocarbon maturation induced increasing pore fluid pressures. This event likely post-dates the Acadian Orogeny because a thick overlying sediment package had not been deposited until this time. The in-situ subsurface stress condition at depths of 10,000 feet or greater during relative tectonic quiescence after the Acadian Orogeny or during the onset of collision associated with the Alleghanian Orogeny would have been: $S_{\mathrm{V}}>S_{\mathrm{Hmax}}>S_{\mathrm{hmin}}$, where $\mathrm{S}_{\mathrm{V}}$ is vertical stress, $\mathrm{S}_{\mathrm{Hmax}}$ is maximum horizontal stress, and $\mathrm{S}_{\mathrm{hmin}}$ is minimum horizontal stress. Joints in this stress condition form parallel to tectonic compression and $\mathrm{S}_{\mathrm{Hmax}}$ (Lorenz et al. 1991). The vertical and sub-vertical E-W striking joints could also have formed under low differential stresses, where $\mathrm{S}_{\mathrm{Hmax}}$ is slightly greater than $\mathrm{S}_{\mathrm{V}}$, at significantly shallower depths during the late Taconic Orogeny or Acadian Orogeny. The following interpretations assume that the E-W set formed after the Acadian Orogeny, despite there being ambiguity and ongoing debate about this subject.

The presence of mineral-filled rhombochasms suggests a period of strike slip motion in this region. Strike slip motion occurs when: $S_{H \max }>S_{V}>S_{h m i n}$. Therefore, the NW-SE set likely occurred during a period of increased tectonic stress. If the E-W joint set is assumed to have formed after the Acadian Orogeny, and the NW-SE set formed after the E-W set (based upon joint abutment relationships), then the strike-slip motion is likely associated with the Alleghanian Orogeny. Strike slip motion could also be associated with increased tectonic stress during the Acadian Orogeny as long as the E-W set developed prior to peak burial depths. Finally, the un- 
filled joints are interpreted to have formed at the surface or near-surface after significant exhumation, where: $\mathrm{S}_{\mathrm{Hmax}}>\mathrm{S}_{\mathrm{hmin}}>\mathrm{S}_{\mathrm{V}}$. This interpretation is consistent with the observed layerparallel joints in the Dolgeville Formation and a lack of high-density un-filled fractures in Utica Core 74 NY-05.

The most definitive conclusion that can be made from this study is that bentonites in the Utica Shale act as mechanical interfaces. Accordingly, fine-grained siliciclastic and detrital carbonate reservoirs with bentonites should exhibit lower natural fracture permeability due to reduced joint density and connectivity. This has implications for fracture modeling in analog hydrocarbon plays because bentonites are widespread in sedimentary basins.

\section{Summary, Conclusions, \& Future Work}

Outcrops and a core section (Utica Core 74NY-05) of the Flat Creek Shale and Dolgeville Formation are studied to better understand fracture propagation in formations with interbedded, organic-rich shale and detrital carbonate-rich shale. The Flat Creek Shale and Dolgeville Formation are fine-grained, mixed siliciclastic and detrital carbonate rocks that host multiple bentonite layers. There are three dominant sedimentary lithofacies observed in Utica Core 74 NY-05: organic-rich shale, calcilutites, and calcisiltites. The organic-rich shale and calcisiltite lithofacies are compositional end-members, and calcilutites are an approximately equal mixture of organic-rich shale and detrital carbonate. The detrital carbonate-rich layers in both members generally exhibit thicknesses between .5 inches $(\sim 1.3 \mathrm{~cm})$ and 8.0 inches $(\sim 20.3$ $\mathrm{cm})$, whereas the flaser, ripple, and planar laminated layers tend to be less than .5 inches ( 1.3 $\mathrm{cm})$ thick. The maximum thickness of bentonites in this study is $\sim 2$ inches $(\sim 5.1 \mathrm{~cm})$. 
Thin sections of the three lithofacies are analyzed to identify mechanical flaws and the presence of organic material. The sedimentary textures and the amount of organic material associated with each lithofacies are interpreted to be at least partially responsible for the observed fracture stratigraphy in each formation. The organic rich shale sample hosts the most organic content and the largest mechanical flaws in the form of trilobite fossils. The calcilutite sample exhibits the most complex sedimentary textures, including cross bedding and organicrich and detrital carbonate-rich zones. The calcisiltite sample has limited organic content, few mechanical flaws, and a relatively homogenous sedimentary texture. The results of the thin section analysis suggest that the dominant lithofacies in the Flat Creek Shale, organic-rich shale, is the most favorable for fracture propagation, whereas the Dolgeville Formation consists of lithofacies that are less favorable for fracture propagation. A more rigorous assessment of sedimentary textures and their effects on fracture stratigraphy would be required to verify this conclusion.

Outcrops of the Flat Creek Shale and Dolgeville Formation are studied on Canajoharie Creek and Flat Creek near Canajoharie, New York. There is a calcite-filled joint set present at outcrops on both creeks that strikes approximately E-W $\left(280^{\circ}\right)$. The spacing of the E-W joint set is usually regular, with the exception of one location where a swarming nature is observed. Conodont alteration data and fluid inclusion homogenization data suggest that this joint set may have formed in the deep subsurface, below 10,000 feet. A fracture bedding termination analysis is conducted at three outcrops on Flat Creek, and has revealed a tendency for joints to terminate or step-over at bentonites. The joints also preferentially terminate at three particular shale beds, but the mechanical contrast between detrital carbonate-rich and detrital carbonate-poor shales is generally insufficient to inhibit fracture propagation. 
The vein-filled joint density is greater in the Flat Creek Shale than it is in the Dolgeville Formation. The cause of the reduced vein-filled joint density is not entirely resolved by this study, but some conclusions have been drawn based upon observations from the field and Utica Core 74 NY-05. It is clear that the reduced vein-filled joint density in the Dolgeville Formation is not the result of increased bedding thicknesses, because there is no observed relationship between bedding thickness and vein-filled joint spacing. However, there appears to be a correlation between bedding thickness and unfilled fracture spacing in the Dolgeville Formation, which suggests that alternating organic-rich shale and detrital carbonate-rich beds in the Utica Shale act as coherent mechanical units until vertical stress associated with overburden is eliminated. The unfilled fractures are interpreted to be surface or near-surface features because they are not prevalent in the core.

The rock strengths of detrital carbonate-rich and detrital carbonate-lean lithologies are not differentiated by the Schmidt Hammer. The Schmidt Hammer method may provide better results at outcrops that are less weathered. The Schmidt Hammer method is effective when comparing between the shales and bentonites, because the bentonites consistently exhibit lower rock strengths. This may be related to the bentonites having a greater proportion of clay minerals. The mineral composition of the bentonites at the time of joint propagation is unknown, but the fracture stratigraphy suggests that authigenic clays had already developed. There is also the possibility that volcanic ash beds create high mechanical contrast regardless of diagenetic alteration. Fracture models of fine grained siliciclastic and carbonate plays should consider the effect that bentonites might have on reducing fracture permeability.

This project has left many questions unanswered, and it has also produced avenues for further research. The greatest uncertainty in this project is the origin of the E-W joint set; this set 
may have formed during the late Taconic Orogeny, after the Acadian Orogeny, or at some other unknown time. Additional fracture studies in the Utica Shale should have an emphasis on the study of mineral assemblages and fluid inclusion homogenization temperatures in fracture veinfill to better define the fracture sets that are associated with basement structures and hydrothermal activity. The shale mechanical interfaces in the outcrops on Flat Creek are poorly understood. Shale mechanical interfaces may be more apparent in sections of the Utica Shale that lack bentonites; therefore, a fracture bedding termination analysis should be conducted in the lower Flat Creek Shale or higher up in the section in the Indian Castle Shale, where bentonites are absent. Results of the fracture bedding termination analysis may identify attributes of shale mechanical interfaces in the Utica Shale, which could lead to the refinement of inputs for fracture modeling in the subsurface. Lastly, joint-bentonite interactions must be studied in other formations to gain a better understanding of how well the observations from this study can be applied elsewhere. 


\section{References}

Agle, P. A., 2008, Fault-induced fluid migration and mineralization along major faults; Mohawk Valley, NYS as an outcrop analog for the Trenton/Black River gas plays in the Finger Lakes Region, NYS: PhD dissertation, SUNY at Buffalo, 167 p.

Aydin, Adnan., 2009, ISRM Suggested Method for Determination of the Schmidt Hammer Rebound Hardness: Revised Version: International Journal of Rock Mechanics and Mining Sciences, v. 46, no. 3, p. 627-34.

Aydin, A., Basu, A., 2005, The Schmidt hammer in rock material characterization: Engineering Geology. v. 81, p. 1-14.

Bai, T., and Pollard, D. D., 2000, Fracture spacing in layered rocks: a new explanation based on the stress transition: Journal of Structural Geology, v. 22, p. 43-57.

Baird, G. C., and Brett, C. E., 2002, Indian Castle Shale: late synorogenic siliciclastic succession in an evolving Middle to Late Ordovician foreland basin, eastern New York State: Physics and Chemistry of the Earth. v. 27, p. 203-230.

Beardsley, R.W., 1999. Field report, Exhibit C(G) to report: Characterization of Glodes Corners Road reservoir. NYSDEC. http://www.dec.ny.gov/, accessed October 6, 2014.

Bradley, D. C., and Kidd, W.S.F., 1991, Flexural extension of the upper continental crust in collisional foredeeps: Geol. Soc. Amer. Bull. v. 103, p. 1416- 1438.

Cisne, J., Karig, D., Rabe, b., and Hay, B., 1982, Topography and tectonics of the Taconic outer trench slope as revealed through gradient analysis of fossil assemblages: Lethaia, v. 15, p. 229-246.

Cooke, M. L., and Underwood, C. A., 2000, Fracture termination and step-over at bedding interfaces due to frictional slip and interface opening: Journal of Structural Geology, v. 23, p. $223-238$

Cross, G.E., 2004, Fault-related mineralization and fracturing in the Mohawk Valley, Eastern New York State. Master's Thesis, SUNY at Buffalo, 251p.

Delano, J. W., Tice, S. J., Mitchell, C. E., and Goldman, D., 1994, Rhyolitic glass in Ordovician K-bentonites: A new stratigraphic tool: Geology. v. 22, p. 115-118.

English, J. M., 2012, Thermomechanical origin of regional fracture systems: AAPG Bulletin, v. 96, no. 9, 1597-1625.

Engelder, T., Lash, G. G., and Uzcategui, R. S., 2009, Joint sets that enhance production from Middle and upper Devonian gas shales of the Appalachian Basin: AAPG Bulletin, v. 93, no. 7 , p. 857-889 
Epstein, A. G., and Epstein, J. B., 1977, Conodont color alteration - an index to organic metamorphism, Geological Survey Professional Paper, 27 p.

Ettensohn, F.R., 1994. Tectonic control on the formation and cyclicity of major Appalachian unconformities and associated stratigraphic sequences. In: Dennison, J.M., Ettensohn, F.R. (Eds.), Tectonic and eustatic controls on sedimentary cycles.SEPM Concepts in Sedimentology and Paleontology 4, 217-242.

Fisher, K., and Warpinski, N., 2012, Hydraulic-Fracture-Height Growth: Real Data: SPE Production \& Operations, 18 p.

Goldman, D., Mitchell, C. E., Bergstrom, S. M., Delano, J. W., and Tice, S., 1994, K-Bentonites and Graptolite Biostratigraphy in the Middle Ordovician of new York State and Quebec: A New Chronostratigraphic Model: SEPM, v. 9, no. 2, p. 124-143.

Grabau, A.W., 1903 Paleozoic coral reefs. Geological Society of America Bulletin. v. 14, p. 337-352.

Jacobi, R. D., 2002, Basement faults and seismicity in the Appalachian Basin of New York State: Tectonophysics, v. 353, p. 75-113.

Jacobi, R. D., 2010, Fracture and geochemical characteristics of fluid migration in CambroOrdovician units, New York State: NYS energy research and development Authority. 56 p.

Joy, M. P., Mitchell, C. E., and Adhya, S., 2000, Evidence of a tectonically driven sequence succession in the Middle Ordovician Taconic foredeep: Geology. v. 28, p. 727-730.

Laubach, S., E., Olson, J. E., Gross, M. R., 2009, Mechanical and fracture stratigraphy: AAPG Bulletin, v. 93, no. 11, p. 1413-1426.

Lezin, C., Odonne, F., Massonnat, G. J., and Escadeillas, G., 2009, Dependence of joint spacing on rock properties in carbonate strata: AAPG Bulletin v. 93, no. 2, p. 271-290.

Lorenz, J. C., Teufel, L. W., and Warpinski, N. R., 1991, Regional fractures I: a mechanism for the formation of regional fractures at depth in flat-lying reservoirs: AAPG Bulletin. v. 75, no. 11, p. 1714-1737.

Morris, A. P., Ferrill, D. A., and McGinnis, R. N., 2009, Mechanical stratigraphy and faulting in Cretaceous carbonates: AAPG Bulletin. v. 93, p. 1459-1470.

Narr, W., and J. Suppe, 1991, Joint spacing in sedimentary rocks: Journal of Structural Geology, v. 13, p. 1037-1048.

NASA, 2014: http://www.nasa.gov/content/goddard/nasa-finds-2013-sustained-long-term- 
climate-warming-trend/\#.VEV4wvldVik, Accessed October 29, 2014.

Pollard, D. D., and A. Aydin, 1988, Progress in understanding jointing over the past century: Geological Society of America Bulletin, v. 100, no. 8, p. 1181-1204.

Renshaw, C. E., and Pollard, D. D., 1995, An experimentally verified criterion for propagation across unbounded frictional interfaces in brittle, linear elastic materials: International Journal of Rock Mechanics and Mining Sciences \& Geomechanics Abstracts, v. 32, p. 237-249.

Repetski, J. E., Ryder, R. T., Weary, D. J., Harris, A. G., and Trippi, M. H., 2008, Thermal maturity patterns (CAI and \% $\mathrm{R}_{\mathrm{o}}$ ) in Upper Ordovician and Devonian rocks of the Appalachian basin: a major revision of USGS Map I-917-E using new subsurface collections, USGS, $26 \mathrm{p}$.

Rijken, P., and Cooke, M. L. 2001, Role of shale thickness on vertical connectivity of fractures: application of crack-bridging theory to the Austin Chalk, Texas: Tectonophysics. v. 337, p. 117-133.

Schieber, J., Southard, J., and Thaisen, T., 2007, Accretion of mudstone beds from migrating floccule ripples: Science. v. 318, p. 1760-1763.

Schieber, J., Southard, J. B., and Schimmelmann, A., 2010, Lenticular shale fabrics resulting from intermittent erosion of water-rich muds-interpreting the rock record in the light of recent flume experiments: journal of sedimentary research, v. 80, p. 119-128.

Schlumberger, 2014, accessed from: http://www.glossary.oilfield.slb.com/en/Terms.aspx?LookIn=term\%20name\&filter=geot hermal\%20gradient

Shackleton, J. R., M. L. Cooke, and A. J. Sussman, 2005, Evidence for temporally changing mechanical stratigraphy and effects on joint-network architecture: Geology, v. 33, p. $101-104$.

Smith, L. B., 2006, Origin and reservoir characteristics of Upper Ordovician Trenton-Black River hydrothermal dolomite reservoirs in New York, AAPG Bulletin, V. 90, p. 16911728.

Smith, L. B., Schieber, J., Wilson, R., Leone, J., and Nyahay, R., 2013, Field guide for organic rich shales of New York May 2013: Energy Minerals Division of AAPG (EMD) and the Pittsburgh Association of Petroleum Geologists (PAPG), 111 p.

Wise, D., U., and Ganis, G., R., 2009, Taconic orogeny in Pennsylvania: A 15-20 m.y. Apennine-style Ordovician event viewed from its Martic hinterland: Journal of Structural Geology, v. 31, p. 887-899. 
Underwood, C. A., M. L. Cooke, J. A. Simo, and M. A. Muldoon, 2003, Stratigraphic controls on vertical fracture patterns in Silurian dolomite, northeastern Wisconsin: AAPG Bulletin, v. 87, no. 1, p. 121-142. 


\section{Appendix}

\subsection{Appendix A}

\begin{tabular}{|c|c|c|c|c|c|c|c|}
\hline Depth & Assay \# & $\begin{array}{l}\text { DR } \\
(\mathrm{nSv} / \mathrm{h})\end{array}$ & $\mathbf{K}(\%)$ & $\mathbf{U}(\mathbf{p p m})$ & Th(ppm) & Description & Photo \\
\hline 375 & 1491 & 59.6 & 0.8 & 5 & 4.2 & 2-10 slightly lighter, but most likely silt, not detrital carbonate bed & No \\
\hline 376 & 1490 & 54.7 & 1 & 4 & 3.8 & Black & No \\
\hline 377 & 1489 & 56.1 & 0.7 & 4.3 & 5 & $\begin{array}{l}\text { At } 11 \text { ( }<1 / 16 \text { inch calcisiltitic lamina) } \times 2 \text {; At } 6.25 \text { (1/4 inch) alternating calcisiltite } \& \text { shale }+(<1 / 16 \text { inch } \\
\text { calcisiltitic lamina) } \times 3 \text { below }\end{array}$ & No \\
\hline 378 & 1488 & 49.9 & 0.8 & 3.8 & 3.6 & At $6.25(5 / 8)$ Bentonite; At $2(<1 / 16$ inch calcisiltitic lamina) $\mathrm{x} 2$ & No \\
\hline 379 & 1487 & 54.5 & 1 & 3.9 & 3.9 & At 0 (5 inch) Bentonite & No \\
\hline 380 & 1486 & 51.7 & 0.8 & 3.5 & 4.9 & At 1.5-6.0 interbedded with siltstone, beds are about ( $1 / 16$ inch0 thick; At 1 vein hair thin 45 degrees & No \\
\hline 381 & 1485 & 54.8 & 0.9 & 3.5 & 5.3 & $\begin{array}{l}\text { At } 5.75 \text { ( } 1 \text { inch) mostly calcisiltitic bed with discontinuous bedding plane; At } 2-5 \text { hairs throughout } \\
\text { space every ( } 1 / 4 \text { inch) }\end{array}$ & No \\
\hline 382 & 1484 & 55.7 & 1 & 4 & 4 & $\begin{array}{l}\text { At } 9.75 \text { ( }<1 / 16 \text { inch calcisiltitic lamina); At } 2(<1 / 16 \text { inch calcisiltitic lamina }) \text {; At } 6(1 / 4 \text { inch }) \\
\text { alternating calcisiltite \& shale; At } 5.5(<1 / 16 \text { inch calcisiltitic lamina) bed with discontinuous bedding } \\
\text { plane }\end{array}$ & No \\
\hline 383 & 1483 & 55.8 & 0.7 & 4.6 & 4.2 & Black & No \\
\hline 384 & 1482 & 50.4 & 0.9 & 3.4 & 4.2 & ( $<1 / 16$ inch calcisiltitic lamina) every 5 inches or so. Very dark & No \\
\hline 385 & 1481 & 57.5 & 1 & 4.4 & 3.8 & $\begin{array}{l}\text { At } 11.75 \text { (1/16 inch) calcisiltite bed; At } 10 \text { (5/4) mostly shale, limited calcisiltite; At } 9.25 \text { (1/16 inch) } \\
\text { calcilutite }\end{array}$ & No \\
\hline 386 & 1480 & 64.3 & 0.9 & 4.8 & 5.9 & $\begin{array}{l}\text { At } 10.5 \text { ( } 1.5 \text { inch) mostly shale, limited calcisiltite; At } 9 \text { (<1/16 inch calcisiltitic lamina)x } 5 \text { : At } 8 \text { (1/4 } \\
\text { inch) calcisiltite bed with discontinuous bedding plane; At } 7.25 \text { ( } 1 / 4 \text { inch) alternating calcisiltite \& } \\
\text { shale; At 4(1/2 inch) alternating calcisiltite \& shale; At } 3.5 \text { ( } 1 / 8 \text { inch) calcisiltite lamina }+(<1 / 16 \text { inch } \\
\text { calcisiltitic lamina); At } 2 \text { ( } 3 / 4 \text { inch) alternating calcisiltite \& shale bed with discontinuous bedding } \\
\text { plane; At .5 Horizontal burrowing }\end{array}$ & No \\
\hline 387 & 1479 & 57.9 & 0.9 & 4.1 & 5.1 & $\begin{array}{l}\text { At } 11.8 \text { (1/8 inch) calcisiltite bed; At8 }(<1 / 16 \text { inch calcisiltitic lamina }) \times 5 \text {; At } 6.25(<1 / 16 \text { inch } \\
\text { calcisiltitic lamina)x5; At } 4.5 \text { (1/2 inch) mostly shale, limited calcisiltite; At } 2(1 / 2 \text { inch) calcilutite bed; } \\
\text { At } 1.25(<1 / 16 \text { inch calcisiltitic lamina)x } 2\end{array}$ & No \\
\hline 388 & 1478 & 59.4 & 0.9 & 4 & 5.9 & $\begin{array}{l}\text { At } 11.5 \text { ( }<1 / 16 \text { inch calcisiltitic lamina)x } 5 \text {; At } 10.5 \text { horizontal burrow }+(<1 / 16 \text { inch calcisiltitic } \\
\text { lamina); At } 10.25 \text { ( }<1 / 16 \text { inch calcisiltitic lamina); At } 9.5 \text { ( } 1 / 2 \text { inch) alternating calcisiltite \& shale; At } 8 \\
\text { (1.5) calcilutite dominated carbonate bed; At } 7.5(<1 / 16 \text { inch calcisiltitic lamina)x } 5 \text {; At } 7 \text { horizontal } \\
\text { burrows; At } 3.5 \text { ( } 2.5 \text { inch) very small fossils throughout; At } 2.5 \text { ( } 1 / 2 \text { inch) detrital carbonate bed; At } 0 \\
\text { (1/4 inch) alternating calcisiltite \& shale }\end{array}$ & No \\
\hline 389 & 1477 & 33.6 & 0.3 & 0.4 & 8.1 & $\begin{array}{l}\text { At } 10.5 \text { alternating calcisiltite } \& \text { shale; At } 8.75 \text { (1/4 inch) alternating calcisiltite \& shale +horizontal } \\
\text { burrow +fossils; At } 8.25 \text { ( } 1 / 4 \text { inch) alternating calcisiltite \& shale; At } 6.25 \text { ( }<1 / 16 \text { inch calcisiltitic } \\
\text { lamina); At } 5.5 \text { ( }<1 / 16 \text { inch calcisiltitic lamina)x } 2 \text {; At } 3.5 \text { ( } 1 / 16 \text { inch) calcisiltite bed; At } 2 \text { fossil bed; At } \\
0 \text { (3/4 inch) }(<1 / 16 \text { inch calcisiltitic lamina)x } 6\end{array}$ & No \\
\hline 390 & & & & & & Section missing & No \\
\hline 391 & 1476 & 50.4 & 0.8 & 3.6 & 4.3 & $\begin{array}{l}\text { At } 11.5 \text { ( } 3 / 4 \text { inch) mostly calcisiltitic; At } 8.5 \text { (1.75 inch) calcilutite bed; At } 6(1.75 \text { inch })(<1 / 16 \text { inch } \\
\text { calcisiltitic lamina)x10; At } 5 \text { fossils; At } 4 \text { fossils }+(<1 / 16 \text { inch calcisiltitic lamina }) \times 2 \text {; At } 2.75 \text { (1.25 } \\
\text { inch) detrital carbonate bed; At } .5 \text { ( } 2 \text { inch) detrital carbonate bed }\end{array}$ & No \\
\hline 392 & 1475 & 57.7 & 1 & 3.9 & 4.8 & $\begin{array}{l}\text { At } 9.75 \text { ( } 1.75 \text { inch) detrital carbonate bed; At } 6 \text { ( } 1 \text { inch) alternating calcisiltite \& shale; At } 4.25 \text { ( } 3 / 8 \\
\text { inch) calcilutite }\end{array}$ & No \\
\hline
\end{tabular}




\begin{tabular}{|c|c|c|c|c|c|c|c|}
\hline 393 & 1474 & 60.2 & 0.9 & 4.6 & 4.7 & $\begin{array}{l}\text { At } 11.25 \text { (1/4 inch) calcisiltite bed with discontinuous bedding plane; At } 10.5(<1 / 16 \text { inch calcisiltitic } \\
\text { lamina)x4; At } 9.75 \text { ( } 1 / 2 \text { inch) detrital carbonate bed; At } 7.75 \text { ( } 1.25 \text { inch) shale to calcisiltite up +small } \\
\text { fossils; At } 5.75 \text { ( } 1.5 \text { inch) small fossils; At } 5 \text { horizontal burrow; At } 3.75 \text { ( } 1.25 \text { inch) }(<1 / 16 \text { inch } \\
\text { calcisiltitic lamina)x10; At } 3.25 \text { ( } 1 / 4 \text { inch) calcisiltite bed; At } 2.5(<1 / 16 \text { inch calcisiltitic lamina); At } 1 \\
\text { (1/2 inch) ( }<1 / 16 \text { inch calcisiltitic lamina)x } 8\end{array}$ & No \\
\hline 394 & 1473 & 33.8 & 0.1 & 0.8 & 8.3 & $\begin{array}{l}\text { At } 11.5 \text { (3/4 inch) detrital carbonate bed; At } 11 \text { (1/4 inch) alternating calcisiltite \& shale; At } 7 \text { ( } 4 \text { inch) } \\
\text { detrital carbonate bed; At } 6.75 \text { ( } 3 / 8 \text { inch) mostly calcisiltitic; At } 6.25 \text { (1/8 inch) calcisiltite bed with } \\
\text { discontinuous bedding plane; At } 5.75 \text { ( }<1 / 16 \text { inch calcisiltitic lamina); At } 5 \text { ( }<1 / 16 \text { inch calcisiltitic } \\
\text { lamina); At } 4.25 \text { ( } 3 / 8 \text { inch) small fossils + ( }<1 / 16 \text { inch calcisiltitic lamina); At } 4 \text { ( }<1 / 16 \text { inch calcisiltitic } \\
\text { lamina)x2; At } 2 \text { ( } 1 \text { inch) small fossils + ( }<1 / 16 \text { inch calcisiltitic lamina)x6; At } 1.75 \text { (1/4 inch) mostly } \\
\text { calcisiltitic }\end{array}$ & No \\
\hline 395 & 1472 & 49.5 & 0.7 & 4 & 3.8 & $\begin{array}{l}\text { At } 11.75 \text { small fossils; At } 11.25 \text { ( } 1 / 4 \text { inch) alternating calcisiltite \& shale; At } 10.25 \text { (1/2 inch) } \\
\text { alternating calcisiltite \& shale; At } 10 \text { (1/8 inch) mostly calcisiltitic + small fossils; At } 9.5(<1 / 16 \text { inch } \\
\text { calcisiltitic lamina)x6; At } 9 \text { small fossils; At } 7.75 \text { ( } 1 / 4 \text { inch) alternating calcisiltite \& shale; At } 6.75 \\
\text { small fossils; At } 6 \text { ( } 1 / 8 \text { inch) mostly calcisiltitic; At } 4.5 \text { ( } 1.5) \text { detrital carbonate bed with angled base; At } \\
4.25 \text { (1/8 inch) mostly calcisiltitic; At } 3.5 \text { ( } 1 / 4 \text { inch) alternating calcisiltite \& shale+ horizontal burrow; } \\
\text { At } 3.25 \text { (<1/16 inch calcisiltitic lamina)x3; At .75 ( } 1.75 \text { inch) detrital carbonate bed }\end{array}$ & No \\
\hline 396 & 1471 & 30.4 & 0.2 & 0.5 & 7.6 & 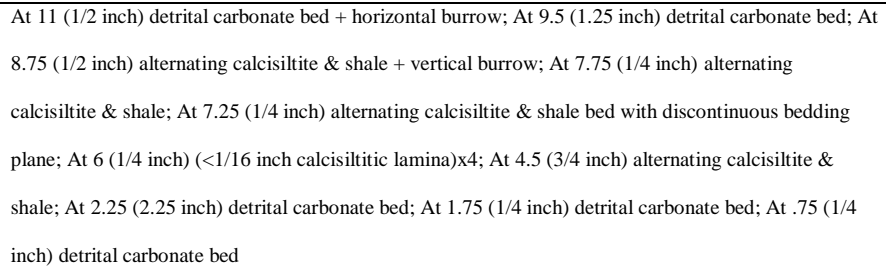 & No \\
\hline 397 & 1470 & 48.8 & 0.8 & 3 & 5 & $\begin{array}{l}\text { At } 11.75 \text { (1/4 inch) angled fossil bed; At } 11.25 \text { (1/8 inch) angled mostly calcisiltitic; At } 10.25 \text { (1/2 inch) } \\
\text { mostly calcilutite, some calcisiltite bed; At } 8.75 \text { ( } 1 / 4 \text { inch) alternating calcisiltite \& shale; At } 8(<1 / 16 \\
\text { inch calcisiltitic lamina); At } 7.25 \text { ( }<1 / 16 \text { inch calcisiltitic lamina); At } 6.75 \text { ( }<1 / 16 \text { inch calcisiltitic } \\
\text { lamina); At } 4.75 \text { (1.25 inch) detrital carbonate bed; At } 3.5 \text { (1.25 inch) alternating calcisiltite \& shale: At } \\
0 \text { (3.5 inch) detrital carbonate bed }\end{array}$ & No \\
\hline 398 & 1469 & 48 & 0.9 & 3.5 & 3.4 & $\begin{array}{l}\text { At } 11 \text { ( } 2 \text { inch) angled detrital carbonate bed; At } 8.75 \text { ( } 1.25 \text { inch) bed with discontinuous bedding plane } \\
+ \text { angled; At } 7.75 \text { ( } 1 / 2 \text { inch) angled detrital carbonate bed; At } 7.5 \text { ( } 1 / 2 \mathrm{inch}) \text { bed with discontinuous } \\
\text { bedding plane; At . } 75 \text { ( } 3 / 4 \mathrm{inch}) \text { detrital carbonate bed; At } 5.5 \text { ( } 1 \mathrm{inch}) \text { detrital carbonate bed; At } 4 \text { (1/2 } \\
\text { inch) small fossils; At } 3 \text { ( } 1 / 2 \mathrm{inch}) \text { alternating calcisiltite \& shale; At } .5 \text { ( } 2.5 \mathrm{inch}) \text { detrital carbonate bed }\end{array}$ & Yes \\
\hline 399 & 1468 & 52.3 & 0.9 & 3.3 & 5.2 & $\begin{array}{l}\text { At } 11.5 \text { soft sed def? At } 10.5 \text { ( } 1 \text { inch) detrital carbonate bed; At } 8.5 \text { ( } 1.5 \text { inch) detrital carbonate bed; At } \\
8 \text { ( } 1 / 4 \text { inch) bed with discontinuous bedding plane; At } 7.25 \text { ( } 1 / 2 \text { inch) alternating calcisiltite \& shale; At } \\
5.25 \text { ( } 1.75 \text { inch) detrital carbonate bed; At } 4.25 \text { ( } 1 / 4 \text { inch) fossils; At } 2.75 \text { ( } 1 / 2 \text { inch) angled alternating } \\
\text { calcisiltite \& shale; At } 1.75(1 / 4 \mathrm{inch}) \text { angled alternating calcisiltite \& shale }\end{array}$ & Yes \\
\hline 400 & 1467 & 44.6 & 0.7 & 3.8 & 2.8 & $\begin{array}{l}\text { At } 8.5 \text { ( } 2.75 \text { inch) angled detrital carbonate bed with horizontal burrow at top; At } 7.25 \text { ( } 3 / 4 \text { inch) angled } \\
\text { mostly calcisiltitic; At } 6 \text { ( } 1 / 2 \text { inch) calcilutite bed; At } 2 \text { ( } 3.25 \text { inch) crenulated? detrital carbonate bed; } \\
\text { At } 1.75 \text { horizontal burrow; At } 0 \text { ( } 3 / 4 \text { inch) alternating calcisiltite \& shale }\end{array}$ & Yes \\
\hline 401 & 1466 & 55 & 0.9 & 4.1 & 4.5 & $\begin{array}{l}\text { At } 10.5 \text { (1.2) alternating calcisiltite \& shale; At } 9.25 \text { ( } 1 / 2 \text { inch) small fossils; At } 8 \text { ( } 1 \text { inch) detrital } \\
\text { carbonate bed; At } 7 \text { ( } 1 / 2 \text { inch) detrital carbonate bed + small fossils; At } 4.5 \text { ( } 1.5 \text { inch) detrital carbonate } \\
\text { bed; At } 3.75 \text { ( } 1 / 8 \text { inch) mostly calcisiltitic + small fossil bed; At } 1.25 \text { ( } 1 / 2 \text { inch) bentonite; At } 0.25 \text { (1/4 } \\
\text { inch) detrital carbonate bed }\end{array}$ & No \\
\hline
\end{tabular}




\begin{tabular}{|c|c|c|c|c|c|c|c|}
\hline 402 & 1465 & 54 & 0.8 & 4.6 & 3.3 & $\begin{array}{l}\text { At } 11 \text { small fossil bed + (<1/16 inch calcisiltitic lamina); At } 8.75 \text { (1.75 inch) detrital carbonate bed } \\
\text { +fossils at top; At } 7.5 \text { ( } 3 / 4 \text { inch) mostly shale, limited calcisiltite; At } 5.75(<1 / 16 \text { inch calcisiltitic } \\
\text { lamina); At } 3.5 \text { ( } 1.25 \text { inch) detrital carbonate bed; At } 2.75 \text { ( } 1 / 4 \text { inch) detrital carbonate bed; At } 2(<1 / 16 \\
\text { inch calcisiltitic lamina); At } 1 \text { ( } 3 / 4 \text { inch) detrital carbonate bed; At } 0(1 / 2 \text { inch) mostly shale, limited } \\
\text { calcisiltite }\end{array}$ & No \\
\hline 403 & 1464 & 52.5 & 1 & 4.5 & 2.4 & $\begin{array}{l}\text { At } 9.75 \text { ( } 2 \text { inch) detrital carbonate bed; At } 9.25 \text { (1/2 inch) alternating calcisiltite \& shale; At } 8.75 \text { ( } 1 / 4 \\
\text { inch) alternating calcisiltite \& shale; At } 7.25 \text { ( }<1 / 16 \text { inch calcisiltitic lamina); At } 6.75(<1 / 16 \text { inch } \\
\text { calcisiltitic lamina); At } 1 \text { ( } 4 \text { inch) detrital carbonate bed }\end{array}$ & No \\
\hline 404 & 1463 & 47.4 & 0.8 & 3.8 & 3.2 & $\begin{array}{l}\text { At } 11.5 \text { ( } 1 / 4 \text { inch) mostly calcisiltitic + vertical burrow; At } 10.25 \text { ( } 1.25 \text { inch) detrital carbonate bed; At } \\
9.25 \text { ( } 3 / 4 \text { inch) alternating calcisiltite \& shale detrital carbonate bed; At } 8 \text { ( } 1 / 8 \text { inch) alternating } \\
\text { calcisiltite \& shale; At } 7 \text { ( } 3 / 4 \text { inch) mostly shale, limited calcisiltite + vertical burrow; At } 5.25 \text { ( } 3 / 4 \\
\text { inch) mostly shale, limited calcisiltite; At } 5 \text { ( } 1 / 4 \text { inch) bentonite; At } 4.25 \text { ( } 1 / 2 \text { inch) detrital carbonate } \\
\text { bed; At } .5 \text { ( } 3 \text { inch) detrital carbonate bed }\end{array}$ & No \\
\hline 405 & 1462 & 42.2 & 0.8 & 2.9 & 3.1 & $\begin{array}{l}\text { At } 11 \text { ( } 1 / 2 \text { inch) alternating calcisiltite \& shale detrital carbonate bed; At } 10.25 \text { ( } 3 / 4 \text { inch) bentonite; At } \\
10(1 / 16 \text { inch) calcisiltite bed }+(<1 / 16 \text { inch calcisiltitic lamina); At } 9.25 \text { (1/4 inch) mostly calcisiltitic; } \\
\text { At } 8.5 \text { ( } 1 / 2 \text { inch) calcilutite dominated carbonate bed }+4(<1 / 16 \text { inch calcisiltitic lamina) above; At } 7.5 \\
\text { (1/8 inch) mostly calcisiltitic; At } 7 \text { ( } 3 / 8 \text { inch) alternating calcisiltite \& shale bed with discontinuous } \\
\text { bedding plane; At } 4.75 \text { ( } 1.75 \text { inch) detrital carbonate bed; At } 4.25 \text { ( } 1 / 4 \text { inch) mostly calcisiltitic; At } 3.25 \\
\text { (1/2 inch) alternating calcisiltite \& shale; At } .75 \text { ( } 1.25 \text { inch) mostly calcisiltitic }\end{array}$ & No \\
\hline 406 & 1459 & 57.9 & 1.2 & 3.9 & 4.1 & $\begin{array}{l}\text { At } 11.25 \text { (1/2 inch) mostly shale, limited calcisiltite bed with discontinuous bedding plane; At } 1 \text { (1/16 } \\
\text { inch) calcilutite bed; At } 9.5 \text { ( } 1 / 2 \text { inch) (<1/16 inch calcisiltitic lamina) +fossil bed; At } 8.5 \text { ( } 1 / 2 \text { inch) } \\
\text { mostly shale, limited calcisiltite; At } 6.5 \text { ( } 2 \text { inch) }(<1 / 16 \text { inch calcilutitic lamina); At } 5.25 \text { ( } 3 / 8 \text { inch) } \\
\text { alternating calcisiltite \& shale; At } 4.25 \text { ( } 3 / 8 \text { inch) calcilutite bed; At } 1 \text { ( } 3 \text { inch) detrital carbonate bed; At } \\
0.25 \text { ( } 1 / 2 \text { inch) alternating calcisiltite \& shale }\end{array}$ & No \\
\hline 407 & 1458 & 52.5 & 1.1 & 2.5 & 5.6 & $\begin{array}{l}\text { At } 10 \text { ( } 3.25 \text { inch) detrital carbonate bed; At } 8(<1 / 16 \text { inch calcisiltitic lamina }) \times 3 \text {; At } 6.25 \text { (1/2 inch) } \\
\text { mostly shale, limited calcisiltite; At } 2.25 \text { ( } 3.25 \mathrm{Inch}) \text { detrital carbonate bed with base (1/2 inch) } \\
\text { alternating calcisiltite \& shale; At } 0.25 \text { ( } 1.25 \text { inch) detrital carbonate bed with bed with discontinuous } \\
\text { bedding plane bottom .5; At } 0(<1 / 16 \text { inch calcisiltitic lamina) } 2\end{array}$ & No \\
\hline 408 & 1457 & 53.5 & 1 & 3.9 & 3.8 & $\begin{array}{l}\text { At } 11.5 \text { (1/2 inch) calcilutite bed; At } 10(<1 / 16 \text { inch calcisiltitic lamina }) \times 2 \text {; At } 1.5 \text { (1.5 inch) }(<1 / 16 \\
\text { inch calcilutitic lamina)x10; At } 6 \text { ( } 1 / 2 \text { inch) alternating calcisiltite \& shale; At } 5.5(1 / 2 \text { inch }) \text { detrital } \\
\text { carbonate bed; At } 5 \text { ( } 1 / 4 \text { inch) alternating calcisiltite \& shale; At } 2(3 \mathrm{inch}) \text { detrital carbonate bed; At } \\
1.75 \text { ( } 1 / 4 \text { inch) detrital carbonate bed }\end{array}$ & No \\
\hline 409 & 1456 & 62.2 & 1 & 3.8 & 6.8 & $\begin{array}{l}\text { At } 9.75 \text { ( } 2.25 \text { inch) detrital carbonate bed with alternating calcisiltite \& shale at base } 1 / 4 \text { inch and wavy } \\
\text { alternating calcisiltite \& shale middle } 1 \text { inch; At } 8.5 \text { ( } 1 / 4 \text { inch) mostly shale, limited calcisiltite; At } 1.25 \\
\text { ( } 1 \text { inch) alternating calcisiltite \& shale detrital carbonate bed; At } 5 \text { ( } 1 / 4 \mathrm{inch}) \text { alternating calcisiltite \& } \\
\text { shale + fossil bed; At } 3.75 \text { (<1/16 inch calcisiltitic lamina)x } 2 \text {; At } 2 \text { ( } 1 / 4 \text { inch) bentonite with calcite? Or } \\
\text { just calcite?; At } 1.5 \text { ( } 1 / 8 \mathrm{inch}) \text { alternating calcisiltite \& shale; At } 0 \text { ( } 3 / 4 \mathrm{inch}) \text { detrital carbonate bed }\end{array}$ & No \\
\hline 410 & 1455 & 46.1 & 1 & 2.3 & 4.8 & $\begin{array}{l}\text { At } 11.25 \text { ( }<1 / 16 \text { inch calcisiltitic lamina); At } 11 \text { ( }<1 / 16 \text { inch calcisiltitic lamina); At } 9.25 \text { ( } 1 \text { inch) } \\
\text { detrital carbonate bed with alternating calcisiltite \& shale at bas } 1 / 4 \text { inch; At } 9.2(<1 / 16 \text { inch calcisiltitic } \\
\text { lamina); At } 7 \text { ( } 3 / 4 \text { inch) mostly calcisiltitic with scour base or burrows?; At } 5.5(1 / 8 \text { inch) mostly } \\
\text { calcisiltitic; At } 5.75 \text { ( }<1 / 16 \text { inch calcisiltitic lamina); At } .75(3.25 \text { inch) detrital carbonate bed with } \\
\text { wavy mostly calcisiltitic at base } 1 \text { inch; At } .25 \text { ( } 1 / 4 \text { inch) mostly shale, limited calcisiltite }\end{array}$ & No \\
\hline
\end{tabular}




\begin{tabular}{|c|c|c|c|c|c|c|c|}
\hline 411 & 1454 & 47.8 & 1 & 2.4 & 5.1 & $\begin{array}{l}\text { At } 8 \text { ( } 4 \text { inch) detrital carbonate bed; At } 7.25 \text { ( } 1 / 2 \text { inch) calcisiltite \& calcilutite bed; At } 6.75 \text { (1/4 inch) } \\
\text { mostly calcilutite, some calcisiltite bed; At } 6 \text { ( } 1 / 2 \text { inch) alternating calcisiltite \& shale; At } 4.5 \text { ( } 1.5 \text { inch) } \\
\text { detrital carbonate bed; At } 3.5 \text { ( } 3 / 4 \text { inch) alternating calcisiltite \& shale bed with discontinuous bedding } \\
\text { plane; At } 2 \text { ( } 1 \text { inch) detrital carbonate bed with alternating calcisiltite \& shale; At } 1 \text { (1/2 inch) } \\
\text { alternating calcisiltite \& shale horizontal burrow at top }\end{array}$ & No \\
\hline 412 & 1453 & 56.3 & 1.1 & 3.7 & 4.4 & $\begin{array}{l}\text { At } 11 \text { (1.5) detrital carbonate bed; At } 10.25 \text { ( } 3 / 4 \text { inch) mostly shale, limited calcisiltite planar; At } 9 \text { (1/2 } \\
\text { inch) mostly shale, limited calcisiltite; At } 5.25 \text { ( } 3.25 \text { inch) detrital carbonate bed; At } 4.5 \text { fossil bed; At } \\
2.75 \text { ( } 1 \text { inch) detrital carbonate bed with alternating calcisiltite \& shale at base } 1 / 4 \text { inch; At } 1.5 \text { ( } 3 / 4 \\
\text { inch) mostly calcilutite, some calcisiltite bed planar; At } .5 \text { ( } 1 / 4 \text { inch) detrital carbonate bed }+(<1 / 16 \\
\text { inch calcisiltitic lamina) }\end{array}$ & No \\
\hline 413 & 1452 & 53.6 & 1 & 3.6 & 4.3 & $\begin{array}{l}\text { At } 11.5 \text { (1/8 inch) mostly calcisiltitic }+(<1 / 16 \text { inch calcisiltitic lamina) above; At } 10 \text { (1/4 inch) mostly } \\
\text { calcilutitic; At } 9.25 \text { (<1/16 inch calcisiltitic lamina); At } 8.25 \text { ( }<1 / 16 \text { inch calcisiltitic lamina); At } 7.75 \\
\text { ( }<1 / 16 \text { inch calcisiltitic lamina)x2; At } 7.25 \text { ( }<1 / 16 \text { inch calcisiltitic lamina)x } 4 \text {; At } 6(1 \text { inch) mostly } \\
\text { calcisiltitic planar at base } 1.2 \text {; At } 5.5 \text { (1/4 inch) alternating calcisiltite \& shale; At } 4.5 \text { alternating } \\
\text { calcisiltite \& shale; At } 3 \text { (1/8 inch) bed with discontinuous bedding plane + }(<1 / 16 \text { inch calcisiltitic } \\
\text { lamina); At } 2.25 \text { (1/4 inch) mostly shale, limited calcisiltite bed with discontinuous bedding plane; At } 1 \\
\text { fossil }\end{array}$ & No \\
\hline 414 & 1451 & 51.4 & 0.8 & 2.5 & 6.8 & $\begin{array}{l}\text { At } 11.75 \text { (<1/16 inch calcisiltitic lamina)x4; At } 9.5 \text { ( }<1 / 16 \text { inch calcisiltitic lamina); At } 8.5 \text { ( }<1 / 16 \text { inch } \\
\text { calcisiltitic lamina); At } 8.25 \text { ( }<1 / 16 \text { inch calcisiltitic lamina); At } 7.5 \text { (1/16 inch) calcisiltite bed; At } 3.75 \\
\text { (3.25 inch) detrital carbonate bed; At } 0 \text { (1.75 inch) detrital carbonate bed with calcilutite lamination at } \\
\text { base } 1 / 2 \text { inch }\end{array}$ & No \\
\hline 415 & 1450 & 53.7 & 1.2 & 3.5 & 3.5 & $\begin{array}{l}\text { At } 11.5 \text { (1/8 inch) mostly shale, limited calcisiltite; At } 9.75 \text { (1/4 inch) mostly shale, limited calcisiltite; } \\
\text { At } 9 \text { (<1/16 inch calcisiltitic lamina)x } 2 \text {; At } 4 \text { ( } 2.5 \text { inch) detrital carbonate bed; At } 3.25(<1 / 16 \text { inch } \\
\text { calcisiltitic lamina); At } 2.25(<1 / 16 \text { inch calcisiltitic lamina) } 33 \text {; At } 1.5(<1 / 16 \text { inch calcisiltitic lamina); } \\
\text { At } 1 \text { (<1/16 inch calcisiltitic lamina); At } 0(<1 / 16 \text { inch calcisiltitic lamina) }\end{array}$ & No \\
\hline 416 & 1449 & 51.4 & 1 & 3.4 & 4.1 & $\begin{array}{l}\text { At } 11.5 \text { ( } 4.5 \text { inch) detrital carbonate bed; At } 11 \text { ( } 1 / 4 \text { inch) alternating calcisiltite \& shale; At } 7.5 \text { ( } 3 / 4 \\
\text { inch) detrital carbonate bed with } L \text { planar at base } 1 / 4 \text { inch; At } 6.75 \text { ( }<1 / 16 \text { inch calcisiltitic lamina); At } \\
4 \text { ( } 2 \text { inch) detrital carbonate bed with vertical burrow at top and alternating calcisiltite \& shale planar at } \\
\text { base } 1 / 2 \text { inch and top } 1 / 2 \text { inch; At } 2.75 \text { ( } 1 / 4 \text { inch) mostly shale, limited calcisiltite }\end{array}$ & No \\
\hline 417 & 1448 & 49.9 & 1 & 3.6 & 3.4 & $\begin{array}{l}\text { At } 9.5 \text { (3/4 inch) mostly calcisiltitic planar; At } 7.5 \text { small fossils; At } 4.5 \text { ( } 1 / 2 \text { inch) alternating calcisiltite } \\
\text { \& shale + vertical burrow; At } 3.75 \text { ( } 1 / 2 \text { inch) mostly shale, limited calcisiltite planar }\end{array}$ & No \\
\hline 418 & 1447 & 58.5 & 1.2 & 3.9 & 4.4 & $\begin{array}{l}\text { At } 11.5 \text { (1/4 inch) alternating calcisiltite \& shale; At } 10.5 \text { (1/2 inch) mostly calcisiltitic; At } 10 \text { (1/4 inch) } \\
\text { alternating calcisiltite \& shale; At } 7.5 \text { ( } 2.25 \text { inch) detrital carbonate bed; At } 1.25(<1 / 16 \text { inch calcisiltitic } \\
\text { lamina); At } 5.5 \text { ( } 1 \mathrm{inch}) \text { detrital carbonate bed; At } 4.25 \text { ( } 1 / 4 \mathrm{inch}) \text { mostly shale, limited calcilutite; At } 3 \\
\text { ( } 1 \text { inch) detrital carbonate bed; At } 2.75 \text { ( } 1 / 4 \text { inch) alternating calcisiltite \& shale bed with discontinuous } \\
\text { bedding plane; At } 2.25 \text { ( } 1 / 4 \text { inch) mostly calcisiltitic; At } 0.25 \text { ( }<1 / 16 \text { inch calcisiltitic lamina) }\end{array}$ & No \\
\hline 419 & 1446 & 58.1 & 1.1 & 3.7 & 5 & $\begin{array}{l}\text { At } 7.75 \text { (4.25) detrital carbonate bed; At } 7.5 \text { ( } 1 / 4 \text { inch) mostly shale, limited calcisiltite; At } 6 \text { ( } 1 \text { inch) } \\
\text { mostly calcilutitic bed with discontinuous bedding plane at base; At } 4 \text { ( } 2 \text { inch) detrital carbonate bed + } \\
\text { fossil at top; At } 3.5 \text { alternating calcisiltite \& shale; At } 3 \text { ( } 1 / 4 \text { inch) alternating calcisiltite \& shale bed } \\
\text { with discontinuous bedding plane; At } 2.5 \text { ( } 1 / 2 \text { inch) alternating calcisiltite \& shale; At } 0 \text { ( } 2.5 \text { inch) } \\
\text { detrital carbonate bed }\end{array}$ & No \\
\hline
\end{tabular}




\begin{tabular}{|c|c|c|c|c|c|c|c|}
\hline 420 & 1445 & 61 & 0.8 & 4.9 & 4.8 & $\begin{array}{l}\text { At } 11 \text { ( } 1 \text { inch) calcisiltite bed with calcilutite at bottom; At } 9.5 \text { ( } 1.5 \text { inch) detrital carbonate bed; At } 8.75 \\
\text { ( } 1 / 4 \text { inch) mostly calcisiltitic; At } 5.75 \text { ( } 2 \text { inch) detrital carbonate bed with alternating calcisiltite \& } \\
\text { shale at base; At } 4.75 \text { ( } 3 / 4 \text { inch) alternating calcisiltite } \& \text { shale; At } 3.5 \text { ( } 1.25 \text { inch) detrital carbonate } \\
\text { bed; At } 2.75 \text { ( } 1 / 16 \text { inch) calcisiltite bed; At } 2 \text { (<1/16 inch calcilutitic lamina)x } 3 \text {; At } 1.25 \text { ( } 1 / 8 \text { inch) } \\
\text { mostly calcisiltitic; At } .75 \text { ( } 1 / 4 \text { inch) mostly shale, limited calcisiltite + horizontal burrow; At } 0 \text { ( } 1 / 4 \\
\text { inch) alternating calcisiltite \& shale }\end{array}$ & No \\
\hline 421 & 1444 & 60.8 & 1.2 & 3.3 & 6.3 & $\begin{array}{l}\text { At } 2.5 \text { (7.75 inch) detrital carbonate bed; At } 6.5 \text { (1/2 inch) alternating calcisiltite \& shale; At } 6 \text { (1/16 } \\
\text { inch) calcisiltite bed; At } 5.5 \text { ( } 1 / 4 \text { inch) mostly calcilutite, some calcisiltite bed +vertical burrow; At } 4.5 \\
\text { (3/4 inch) alternating calcisiltite \& shale; At } 4 \text { ( } 1 / 4 \text { inch) mostly calcilutite, some calcisiltite bed; At } 3 \\
\text { (<1/16 inch calcisiltitic lamina); At } 2(1 / 2 \text { inch) bentonite }\end{array}$ & No \\
\hline 422 & 1443 & 61.2 & 1.1 & 4.3 & 4.9 & $\begin{array}{l}\text { At } 11.25 \text { ( }<1 / 16 \text { inch calcisiltitic lamina)x3; At } 11.5 \text { (1/8 inch) mostly shale, limited calcilutite bed with } \\
\text { discontinuous bedding plane; At } 10.5 \text { ( } 1 / 16 \text { inch) calcisiltite bed; At } 9.75 \text { ( } 1 / 16 \text { inch) calcisiltite bed } \\
\text { with discontinuous bedding plane; At } 8.75 \text { ( } 1 / 4 \text { inch) alternating calcisiltite \& shale bed with } \\
\text { discontinuous bedding plane; AT } 8.25 \text { ( }<1 / 16 \text { inch calcisiltitic lamina); At } 8 \text { (1/8 inch) alternating } \\
\text { calcisiltite \& shale bed with discontinuous bedding plane + fossils; At } 7.75 \text { ( } 1 / 8 \text { inch) mostly } \\
\text { calcisiltitic + ( } 1 / 16 \text { inch) calcisiltite bed with discontinuous bedding plane above + fossils; At } 6.5 \text { ( } 1 / 8 \\
\text { inch) mostly shale, limited calcisiltite bed with discontinuous bedding plane; At } .25 \text { (1/16 inch) } \\
\text { alternating calcisiltite \& shale; At } 4.75 \text { ( } 1 / 2 \text { inch) alternating calcisiltite \& shale }\end{array}$ & No \\
\hline 423 & 1442 & 59.9 & 1.2 & 3.2 & 6.3 &  & No \\
\hline 424 & 1441 & 61.7 & 1.2 & 3.5 & 6 & $\begin{array}{l}\text { At } 11.75 \text { ( } 1 / 4 \text { inch) alternating calcisiltite \& shale; At } 8.75 \text { ( } 3 \text { inch) detrital carbonate bed; At } 7.75 \text { ( } 1 \\
\text { inch) alternating calcisiltite \& shale with soft sediment deformation at } 8.5 \text {; At } 7.25 \text { ( } 3 / 8 \text { inch) mostly } \\
\text { calcilutite, some calcisiltite bed; At } 6 \text { ( } 1 / 8 \text { inch) calcisiltite bed with discontinuous bedding plane; At } \\
5.75 \text { ( } 1 / 8 \text { inch) mostly calcisiltitic; At } 5.5 \text { ( } 1 / 4 \text { inch) mostly calcisiltitic; At } 4.5(1 / 2 \text { inch) mostly } \\
\text { calcisiltitic bed with discontinuous bedding plane; At } 3.5 \text { ( } 1 / 2 \text { inch) mostly shale, limited calcilutite bed } \\
\text { with discontinuous bedding plane; At } 1.75 \text { ( } 1 \text { inch) detrital carbonate bed with calcisiltite bed with } \\
\text { discontinuous bedding plane at } 2 \text {; At } 1 \text { ( }<1 / 16 \text { inch calcisiltitic lamina) } 5\end{array}$ & Yes \\
\hline 425 & 1440 & 57.7 & 0.9 & 4.4 & 4.4 & $\begin{array}{l}\text { At } 12 \text { ( } 1 / 4 \text { inch) calcilutite bed; At } 11.5 \text { ( } 1 / 4 \text { inch) mostly calcilutite, some calcisiltite bed; At } 11.25 \\
\text { ( }<1 / 16 \text { inch calcisiltitic lamina); At } 10.5 \text { alternating calcisiltite \& shale bed with discontinuous bedding } \\
\text { plane; At } 10 \text { mostly shale, limited calcisiltite; At } 8.25 \text { ( } 3 / 4 \text { inch) detrital carbonate bed with ( } 1 / 16 \text { inch) } \\
\text { calcisiltite x } 2 \text { at top; At } 8 \text { ( }<1 / 16 \text { inch calcisiltitic lamina)x } 3 \text {; At } 6.75 \text { ( } 1 / 2 \text { inch) mostly shale, limited } \\
\text { calcisiltite bed with discontinuous bedding plane; At } 4.25 \text { small fossil bed; At } 3.25 \text { ( } 1 / 8 \text { inch) calcisiltite } \\
\text { bed; At } 2.5 \text { ( } 1 / 4 \text { inch) alternating calcisiltite \& shale bed with discontinuous bedding plane + fossil bed; } \\
\text { At } 1.5 \text { ( } 1 / 2 \text { inch) mostly shale, limited calcisiltite; At } .75 \text { ( } 1 / 2 \text { inch) mostly calcilutite, some calcisiltite } \\
\text { bed; At } .25 \text { ( } 1 / 16 \text { inch) detrital carbonate bed }\end{array}$ & No \\
\hline 426 & 1439 & 53.8 & 1.1 & 3.2 & 4.7 & $\begin{array}{l}\text { At } 9 \text { ( } 3 \text { inch) detrital carbonate bed with ( } 1 / 2 \text { inch) alternating calcisiltite } \& \text { shale at } 9.5 \text {; At } 8 \text { (1/2 inch) } \\
\text { detrital carbonate bed }+(<1 / 16 \text { inch calcisiltitic lamina) } 33 \text { above; At } 7.75 \text { ( } 1 / 16 \text { inch) calcilutite bed } \\
\text { with discontinuous bedding plane; At } 2 \text { ( } 4.25 \text { inch) detrital carbonate bed with crisscrossing veins, At } \\
0.75 \text { ( } 1 \text { inch) detrital carbonate bed with burrows at top }\end{array}$ & Yes \\
\hline
\end{tabular}




\begin{tabular}{|c|c|c|c|c|c|c|c|}
\hline 427 & 1438 & 58.4 & 1 & 3.8 & 5.5 & $\begin{array}{l}\text { At (11.75) (<1/16 inch calcisiltitic lamina); At } 11.5 \text { ( } 1 / 4 \text { inch) mostly shale, limited calcilutite; At } 10.5 \\
\text { (1/4 inch) alternating calcisiltite \& shale; AT } 10 \text { (1/8 inch) mostly calcisiltitic; At } 9.25(<1 / 16 \text { inch } \\
\text { calcisiltitic lamina)x5; At } 9 \text { ( } 1 / 8 \text { inch) calcisiltite bed; At } 8.5 \text { ( }<1 / 16 \text { inch calcisiltitic lamina)x } 2 \text {; At } 7.5 \\
\text { (1/2 inch) mostly calcisiltitic; At } 7 \text { ( }<1 / 16 \text { inch calcisiltitic lamina); At } 6.5 \text { ( } 1 / 16 \text { inch) calcilutite bed; } \\
\text { At } 5.25 \text { ( } 1 / 4 \text { inch) alternating calcisiltite \& shale; At } 0(4.5) \text { detrital carbonate bed with ( } 1 / 2 \text { inch) } \\
\text { detrital carbonate bed at } 4 \text { with ( } 1 \text { inch) alternating calcisiltite \& shale bed with discontinuous bedding } \\
\text { plane at } 2\end{array}$ & No \\
\hline 428 & 1437 & 53.8 & 0.9 & 3.3 & 5.3 & 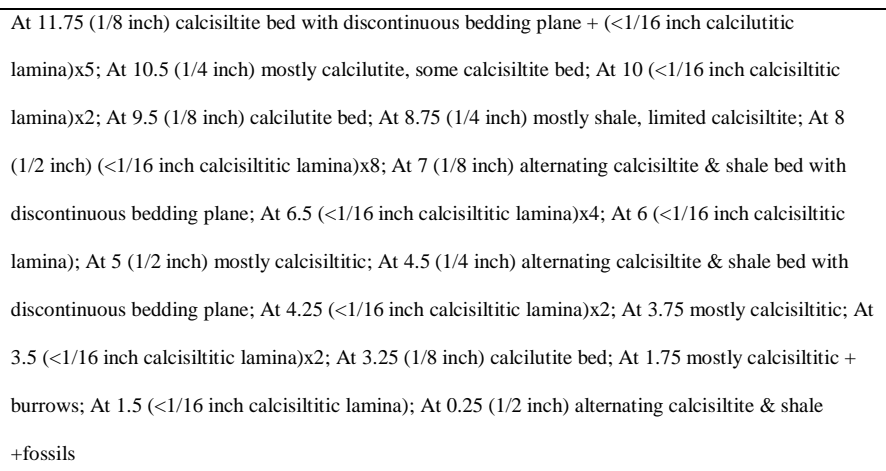 & No \\
\hline 429 & 1436 & 54.1 & 1.3 & 3.4 & 3.4 & $\begin{array}{l}\text { At } 11.75 \text { ( }<1 / 16 \text { inch calcisiltitic lamina)x } 2 \text {; At } 11 \text { (1/8 inch) mostly calcisiltitic; At 9.5 (1/2 inch) } \\
\text { mostly shale, limited calcisiltite; At } 7.5 \text { ( } 1 / 4 \text { inch) alternating calcisiltite \& shale + burrows; At } 4.5 \\
\text { ( } 3.25 \text { inch) detrital carbonate bed with ( } 1 / 16 \text { inch) calcisiltite at base; At } 4.5 \text { ( }<1 / 16 \text { inch calcisiltitic } \\
\text { lamina); At } 4 \text { ( } 1 / 2 \text { inch) alternating calcisiltite \& shale; At } 3.25 \text { ( } 1 / 2 \text { inch) alternating calcisiltite \& } \\
\text { shale; At } 2 \text { ( } 1 / 2 \text { inch) alternating calcisiltite \& shale bed with discontinuous bedding plane; At } 1.75 \\
\text { (1/16 inch) calcisiltite bed; At } 0 \text { ( } 1 / 4 \text { inch) mostly calcisiltitic }\end{array}$ & No \\
\hline 430 & 1435 & 57.4 & 1.2 & 3.2 & 5.2 & $\begin{array}{l}\text { At } 11.5 \text { (1/4 inch) mostly calcisiltitic; At } 8.75 \text { ( } 2.25 \text { inch) detrital carbonate bed; At } 6 \text { ( } 2.25 \text { inch) bed } \\
\text { with discontinuous bedding plane; At } 3.75 \text { (2) detrital carbonate bed + wavy at top; At } 3.25 \text { (1/2 inch) } \\
\text { mostly shale, limited calcisiltite, wavy; At } 1.75 \text { ( } 1.25 \text { inch) detrital carbonate bed; At } 1.5 \text { ( }<1 / 16 \text { inch } \\
\text { calcisiltitic lamina)x } 5\end{array}$ & Yes \\
\hline 431 & 1434 & 58.6 & 1 & 3.9 & 5.1 & $\begin{array}{l}\text { At } 11.9 \text { ( }<1 / 16 \text { inch calcisiltitic lamina); At } 11 \text { calcisiltite bed with discontinuous bedding plane; At } \\
9.25 \text { (1/2 inch) mostly calcisiltitic bed with discontinuous bedding plane; At } 9(<1 / 16 \text { inch calcisiltitic } \\
\text { lamina); At } 8.75 \text { fossil?; At } 8 \text { ( }<1 / 16 \text { inch calcisiltitic lamina); At } 4.5 \text { ( } 3.5 \text { inch) detrital carbonate bed } \\
\text { with ( } 1 / 4 \text { inch) alternating calcisiltite \& shale at } 7 \text {; At } 4 \text { ( }<1 / 16 \text { inch calcisiltitic lamina); At } 3.75 \text { fossils; } \\
\text { At } 3 \text { alternating calcisiltite \& shale ( } 1 / 2 \text { inch); At } 2.25 \text { (1/4 inch) alternating calcisiltite \& shale bed } \\
\text { with discontinuous bedding plane with fossils + burrows; At } 2(<1 / 16 \text { inch calcisiltitic lamina) } 44 \text {; At } \\
1.25 \text { ( } 1 / 2 \text { inch) detrital carbonate bed }\end{array}$ & No \\
\hline 432 & 1432 & 55.2 & 1.1 & 3 & 5.3 & $\begin{array}{l}\text { At } 11.75 \text { ( }<1 / 16 \text { inch calcisiltitic lamina })+(1 / 16 \text { inch) calcisiltite bed; At } 11.25 \text { ( }<1 / 16 \text { inch calcisiltitic } \\
\text { lamina)x6; At } 10.75 \text { ( } 3 / 4 \text { inch) detrital carbonate bed; At } 10 \text { ( } 1 / 16 \text { inch) calcisiltite bed x2; At } 9(1 / 16 \\
\text { inch) calcisiltite bed; At } 8 \text { ( } 1 / 16 \text { inch) calcilutite bed; At } 7.5 \text { ( } 1 / 8 \text { inch) calcilutite bed with } \\
\text { discontinuous bedding plane; At } 7 \text { horizontal burrow; At } 6.25 \text { ( }<1 / 16 \text { inch calcisiltitic lamina); At } 5.5 \\
\text { (1/4 inch) alternating calcisiltite \& shale; At } 4.5 \text { ( }<1 / 16 \text { inch calcisiltitic lamina); At } 3.75 \text { (1/8 inch) } \\
\text { calcisiltite bed with discontinuous bedding plane; At } 3.25 \text { ( } 1 / 4 \text { inch) mostly calcisiltitic }+ \text { fossil bed; At } \\
2.25 \text { ( } 1 / 4 \text { inch) mostly calcilutite, some calcisiltite bed; At } 0.5(1 / 2 \text { inch) mostly calcisiltitic; At } 0 \text { ( } 1 / 16 \\
\text { inch) calcisiltite bed }\end{array}$ & No \\
\hline
\end{tabular}




\begin{tabular}{|c|c|c|c|c|c|c|c|}
\hline 433 & 1431 & 55.4 & 1.1 & 3.2 & 5.4 & $\begin{array}{l}\text { At } 11 \text { (1/8 inch) calcisiltite bed; At } 10 \text { (1/8 inch) calcisiltite bed; At } 7.5(<1 / 16 \text { inch calcilutitic } \\
\text { lamina)x3; At } 1.25 \text { ( }<1 / 16 \text { inch calcisiltitic lamina); At } 5.75 \text { (1/4 inch) bentonite; At } 4.5(1 / 16 \text { inch }) \\
\text { calcisiltite bed + (<1/16 inch calcilutitic lamina)x3; At } 3(<1 / 16 \text { inch calcisiltitic lamina); At } 2.5(<1 / 16 \\
\text { inch calcisiltitic lamina); At } 2.75 \text { ( }<1 / 16 \text { inch calcisiltitic lamina); At } 0 \text { (1/4 inch) mostly calcilutite, } \\
\text { some calcisiltite bed }\end{array}$ & No \\
\hline 434 & 1430 & 53.8 & 1.3 & 2.3 & 5.5 & 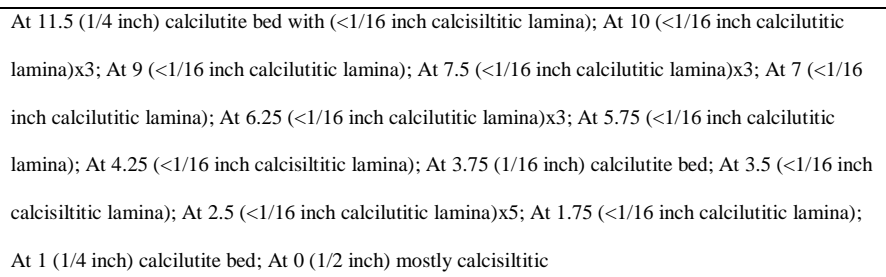 & No \\
\hline 435 & 1429 & 59 & 0.8 & 4.6 & 5 & $\begin{array}{l}\text { At } 6.5 \text { ( } 5 \text { inch) detrital carbonate bed; At } 6.25 \text { ( } 1 / 8 \text { inch) calcisiltite bed; At } 5.75 \text { (1/4 inch) alternating } \\
\text { calcisiltite \& shale bed with discontinuous bedding plane; At } 5 \text { ( } 1 / 2 \text { inch) alternating calcisiltite \& shale } \\
\text { detrital carbonate bed; At } 4.75 \text { ( } 1 / 16 \text { inch) calcisiltite bed; At } 4.25 \text { ( } 1 / 4 \text { inch) mostly calcisiltitic; At } \\
3.25 \text { ( } 1 / 2 \text { inch) calcilutite bed with discontinuous bedding plane; At } 2.75 \text { ( } 1 / 4 \text { inch) alternating } \\
\text { calcisiltite \& shale; At } 2.5 \text { horizontal burrow?; At } 1 \text { ( } 1 / 4 \text { inch) mostly calcilutite, some calcisiltite bed }\end{array}$ & No \\
\hline 436 & 1428 & 66.5 & 1.1 & 4.7 & 5.7 & 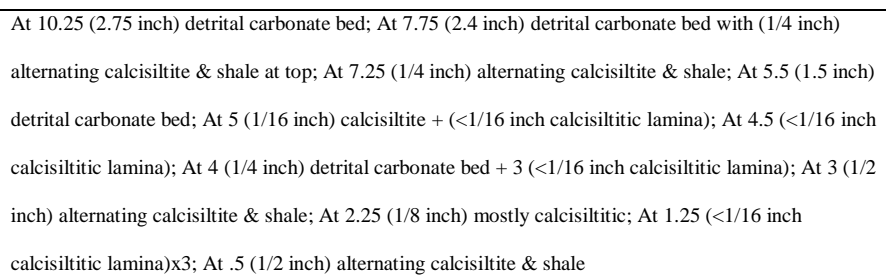 & No \\
\hline 437 & 1427 & 59.2 & 1 & 3.9 & 5.5 & $\begin{array}{l}\text { At } 11 \text { (3/4 inch) alternating calcisiltite \& shale; At } 10.75 \text { ( }<1 / 16 \text { inch calcisiltitic lamina)x4; At } 10 \text { (1/4 } \\
\text { inch) alternating calcisiltite \& shale; At } 9.75 \text { ( }<1 / 16 \text { inch calcisiltitic lamina); At } 9.25 \text { (1/4 inch) mostly } \\
\text { shale, limited calcisiltite; At } 8 \text { (1/4 inch) mostly shale, limited calcisiltite; At } 5 \text { ( } 2.5 \text { inch) detrital } \\
\text { carbonate bed with horizontal burrow at top?; At } 4.75 \text { ( }<1 / 16 \text { inch calcilutitic lamina)x5; At } 3.5 \text { ( }<1 / 16 \\
\text { inch calcisiltitic lamina); At } 2.25 \text { ( } 1 / 4 \text { inch) mostly shale, limited calcisiltite; At } .25 \text { (1.25 inch) detrital } \\
\text { carbonate bed }\end{array}$ & No \\
\hline 438 & 1426 & 57 & 1.3 & 2.9 & 5.5 & $\begin{array}{l}\text { At } 11 \text { ( } 1 / 2 \text { inch) calcisiltite bed with discontinuous bedding plane + burrow?; At } 10.25 \text { (1/4 inch) } \\
\text { detrital carbonate bed; At } 6.75 \text { ( } 2.75 \text { inch) detrital carbonate bed with } \mathrm{L} \text { at } 9.5 \text { and alternating calcisiltite } \\
\& \text { shale ( } 1 / 4 \text { inch) at } 6.5 \text {; At } 6.75 \text { ( } 1 / 16 \text { inch) calcilutite bed; At } 6.25 \text { ( }<1 / 16 \text { inch calcilutitic lamina); At } \\
4 \text { ( } 2 \text { inches) detrital carbonate bed }+(<1 / 16 \text { inch calcisiltitic lamina); At } 1 \text { ( } 2.5 \text { inch) detrital carbonate } \\
\text { bed; At } 1 \text { ( } 1 / 8 \text { inch) mostly calcisiltitic; At } 0 \text { ( } 1 / 4 \text { inch) alternating calcisiltite \& shale bed with } \\
\text { discontinuous bedding plane }\end{array}$ & No \\
\hline 439 & 1425 & 65 & 1.2 & 3.9 & 6.2 & $\begin{array}{l}\text { At } 11.25 \text { (1/4 inch) detrital carbonate bed; At } 11 \text { ( }<1 / 16 \text { inch calcisiltitic lamina)x2; At } 10.25(1 / 16 \\
\text { inch) calcisiltite bed; At } 9.25 \text { ( } 1 / 2 \text { inch) calcisiltite \& calcilutite bed; At } 8.25(<1 / 16 \text { inch calcisiltitic } \\
\text { lamina); At } 7.75 \text { (1/4 inch) alternating calcisiltite \& shale; At } 7.5(<1 / 16 \text { inch calcisiltitic lamina); At } \\
5.75 \text { ( } 1.25 \text { inch) alternating calcisiltite \& shale; At } 3 \text { ( }<1 / 16 \text { inch calcisiltitic lamina)x } 5 \text {; At } 2.5(<1 / 16 \\
\text { inch calcisiltitic lamina)x2; At } 1.25 \text { ( } 3 / 8 \text { inch) mostly calcilutite, some calcisiltite bed }\end{array}$ & No \\
\hline 440 & 1424 & 52.2 & 1.1 & 2.9 & 5 & $\begin{array}{l}\text { At } 9.5 \text { ( }<1 / 16 \text { inch calcisiltitic lamina); At } 6 \text { (1/4 inch) alternating calcisiltite \& shale; At } 4.5(<1 / 16 \\
\text { inch calcilutitic lamina)x3; At } 3.25 \text { (1/4 inch) mostly shale, limited calcisiltite; At } 2.5(1 / 16 \text { inch }) \\
\text { calcisiltite lamina + }(<1 / 16 \text { inch calcisiltitic lamina); At0 }(1 / 4 \text { inch) alternating calcisiltite \& shale }\end{array}$ & No \\
\hline
\end{tabular}




\begin{tabular}{|c|c|c|c|c|c|c|c|}
\hline 441 & 1423 & 46.8 & 1 & 2.5 & 4.4 & $\begin{array}{l}\text { At } 11 \text { ( } 1 / 8 \text { inch) mostly calcilutitic bed with discontinuous bedding plane; At } 8.75 \text { ( } 3 / 4 \text { inch) detrital } \\
\text { carbonate bed; At } 8.5 \text { ( }<1 / 16 \text { inch calcilutitic lamina)x } 3 \text {; At } 7.5 \text { ( } 1 / 2 \text { inch) detrital carbonate bed; At } \\
5.25 \text { ( } 3 / 4 \text { inch) mostly calcisiltitic bed with discontinuous bedding plane; At } 4.5 \text { ( } 3 / 8 \text { inch) mostly } \\
\text { calcilutite, some calcisiltite bed; At } 4 \text { ( } 1 / 16 \text { inch) calcisiltite bed; At } 3.5 \text { ( } 1 / 4 \text { inch) alternating calcisiltite } \\
\text { \& shale; At } 2.75 \text { alternating calcisiltite \& shale }\end{array}$ & No \\
\hline 442 & 1422 & 54 & 1.2 & 3.5 & 3.5 & 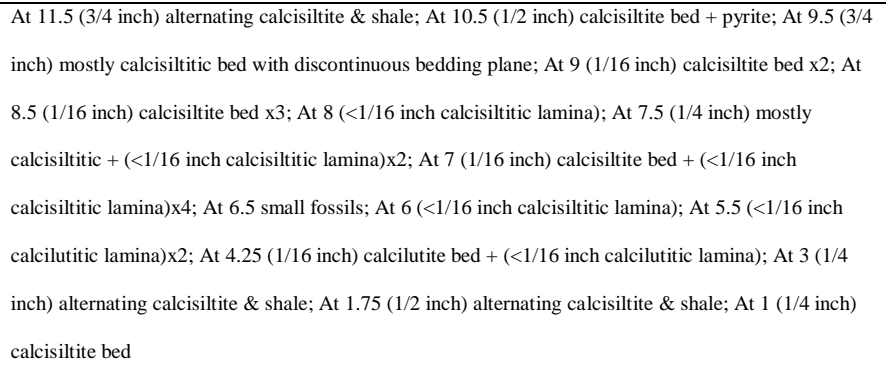 & No \\
\hline 443 & 1421 & 49.8 & 1 & 3 & 4.5 & $\begin{array}{l}\text { At } 11.75 \text { ( }<1 / 16 \text { inch calcilutitic lamina)x2; At } 11 \text { ( }<1 / 16 \text { inch calcilutitic lamina); At } 10.75 \text { (1/4 inch) } \\
\text { mostly shale, limited calcilutite bed with discontinuous bedding plane; At } 10.25 \text { ( }<1 / 16 \text { inch calcisiltitic } \\
\text { lamina); At } 9.25 \text { ( } 1 / 4 \text { inch) mostly calcisiltitic; At } 8 \text { ( } 1 / 2 \text { inch) mostly calcisiltitic bed with } \\
\text { discontinuous bedding plane; At } 7.75 \text { ( }<1 / 16 \text { inch calcisiltitic lamina) } 44+(1 / 4 \text { inch) calcisiltite bed } x 2 \text {; } \\
\text { At } 4 \text { ( } 2.75 \text { inch) detrital carbonate bed; At } 3 \text { ( } 3 / 4 \text { inch) detrital carbonate bed calcisiltite to calcilutite } \\
\text { up; At } 2.25 \text { (1/2 inch) alternating calcisiltite \& shale bed with discontinuous bedding plane; At } 1.75 \\
\text { (1/4 inch) calcisiltite \& calcilutite bed with discontinuous bedding plane }\end{array}$ & No \\
\hline 444 & 1420 & 55.9 & 1.1 & 3.4 & 4.7 & $\begin{array}{l}\text { At } 11.5 \text { ( } 1 / 2 \text { inch) detrital carbonate bed; At } 10.75 \text { ( }<1 / 16 \text { inch calcisiltitic lamina); At } 10 \text { ( } 3 / 8 \text { inch) } \\
\text { detrital carbonate bed with calcisiltite lamination; At } 8.25 \text { ( } 3 / 8 \text { inch) alternating calcisiltite \& shale; At } \\
7.25 \text { ( } 1 / 4 \text { inch) mostly calcisiltitic; At } 1 \text { ( }<1 / 16 \text { inch calcisiltitic lamina); At } 6.25 \text { ( }<1 / 16 \text { inch } \\
\text { calcisiltitic lamina); At } 5.5 \text { ( } 1 / 4 \text { inch) mostly calcilutitic; At } 5 \text { ( } 1 / 4 \text { inch) mostly calcilutitic; At } 4 \text { (1/2 } \\
\text { inch) alternating calcisiltite \& shale; At } 3.5 \text { ( }<1 / 16 \text { inch calcisiltitic lamina); At } 3.25 \text { ( } 1 / 4 \text { inch) } \\
\text { calcisiltite bed with discontinuous bedding plane; At } 3 \text { ( }<1 / 16 \text { inch calcisiltitic lamina); At } 2 \text { (1/8 inch) } \\
\text { mostly calcisiltitic }\end{array}$ & No \\
\hline 445 & 1419 & 53.8 & 1.3 & 2.5 & 5.4 & 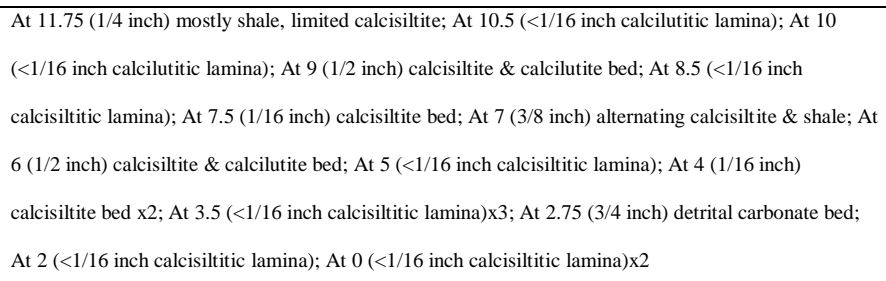 & No \\
\hline 446 & 1418 & 53.9 & 0.9 & 3.3 & 5.3 & $\begin{array}{l}\text { At } 9.5 \text { ( } 1 \text { inch) detrital carbonate bed calcisiltite to calcilutite up; At } 8 \text { ( }<1 / 16 \text { inch calcisiltitic lamina); } \\
\text { At } 7.5 \text { ( }<1 / 16 \text { inch calcisiltitic lamina); At } 7.25 \text { ( }<1 / 16 \text { inch calcilutitic lamina) } 2 \text {; At } 6.5(1 / 4 \text { inch }) \\
\text { alternating calcisiltite \& shale; At } 5.75 \text { (1/16 inch) calcisiltite bed; At } 4.25(1 / 4 \text { inch) alternating } \\
\text { calcisiltite \& shale bed with discontinuous bedding plane; At } 2 \text { ( } 1 / 16 \text { inch) calcisiltite bed; At } 1.25 \\
(<1 / 16 \text { inch calcilutitic lamina); At } 0 \text { (1/2 inch) mostly calcisiltitic }\end{array}$ & No \\
\hline 447 & 1417 & 54.1 & 1.2 & 3.2 & 4.6 & $\begin{array}{l}\text { At } 11 \text { (1/2 inch) alternating calcisiltite \& shale bed with discontinuous bedding plane at base; At } 10.75 \\
\text { ( }<1 / 16 \text { inch calcilutitic lamina)x2; At } 10 \text { ( } 1 / 4 \text { inch) alternating calcisiltite \& shale; At } 9.5(<1 / 16 \text { inch } \\
\text { calcilutitic lamina)x } 3 \text {; At } 9.25 \text { (1/4 inch) mostly shale, limited calcilutite; At } 7.25 \text { (1/8 inch) calcisiltite } \\
\& \text { calcilutite bed; At } 5.5 \text { alternating calcisiltite \& shale; At } 5 \text { ( } 1 / 4 \text { inch) alternating calcisiltite \& shale; } \\
\text { At } 4.5 \text { (<1/16 inch calcilutitic lamina); At } 3.5 \text { ( } 1 / 2 \text { inch) mostly calcisiltitic bed with discontinuous } \\
\text { bedding plane; At } 3 \text { ( } 1 / 4 \text { inch) alternating calcisiltite \& shale; At } 2(1 / 8 \text { inch) mostly calcilutitic; At } 1.5 \\
\text { ( }<1 / 16 \text { inch calcilutitic lamina); At } 1 \text { ( }<1 / 16 \text { inch calcilutitic lamina); At } .5(<1 / 16 \text { inch calcilutitic } \\
\text { lamina) }\end{array}$ & No \\
\hline
\end{tabular}




\begin{tabular}{|c|c|c|c|c|c|c|c|}
\hline 448 & 1416 & 60.1 & 1.1 & 3.4 & 6.5 & $\begin{array}{l}\text { At } 11.75 \text { ( }<1 / 16 \text { inch calcisiltitic lamina); At } 11.5 \text { (1/8 inch) calcisiltite bed }+(<1 / 16 \text { inch calcilutitic } \\
\text { lamina)x2; At } 11 \text { ( } 1 / 8 \text { inch) calcilutite bed; At } 10.25 \text { (1/4 inch) mostly calcisiltitic bed with } \\
\text { discontinuous bedding plane; At } 9.75 \text { ( } 1 / 4 \text { inch) alternating calcisiltite \& shale; At } 9.5 \text { ( } 1 / 4 \text { inch) } \\
\text { alternating calcisiltite \& shale bed with discontinuous bedding plane; At } 9(<1 / 16 \text { inch calcilutitic } \\
\text { lamina)x4; At } 6 \text { ( } 2.5 \text { inch) detrital carbonate bed with alternating calcisiltite \& shale bed with } \\
\text { discontinuous bedding plane at top; At } 3.25 \text { ( } 1.5 \text { inch) detrital carbonate bed with ( } 1 / 4 \text { inch) calcisiltite } \\
\text { bed at bottom; At } 2.5 \text { ( } 1 / 4 \text { inch) alternating calcisiltite \& shale; At } 1.5 \text { ( } 1 / 2 \text { inch) mostly shale, limited } \\
\text { calcisiltite; At } .75 \text { ( } 1 / 4 \text { inch) mostly calcisiltitic bed with discontinuous bedding plane }\end{array}$ & No \\
\hline 449 & 1415 & 59.4 & 1.2 & 3.7 & 4.8 &  & No \\
\hline 450 & 1414 & 54.5 & 1 & 3.3 & 5.3 & 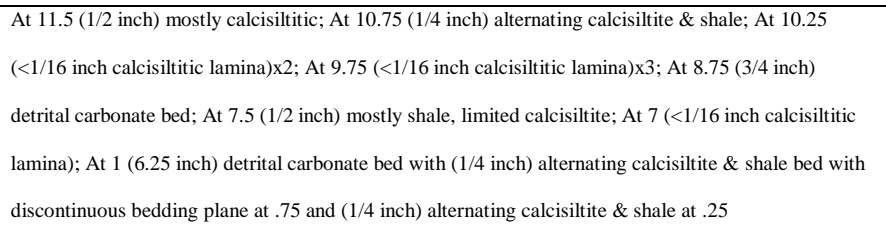 & No \\
\hline 451 & 1413 & 51.5 & 1.2 & 2.9 & 4.3 & $\begin{array}{l}\text { At } 11.75 \text { ( } 1 / 4 \text { inch) alternating calcisiltite \& shale bed with discontinuous bedding plane; At } 11.5 \\
(<1 / 16 \text { inch calcisiltitic lamina); At } 10.5 \text { ( }<1 / 16 \text { inch calcisiltitic lamina) } 2 \text {; At } 9.25 \text { ( } 3 / 4 \text { inch) detrital } \\
\text { carbonate bed with ( }<1 / 16 \text { inch calcisiltitic lamina) } 4 \text {; At } 8.75 \text { ( } 1 / 4 \text { inch) alternating calcisiltite \& shale; } \\
\text { At } 4.5 \text { ( } 3.75 \text { inch) detrital carbonate bed; At } 3.25 \text { ( } 3 / 4 \text { inch) mostly calcisiltitic; At } 2 \text { ( } 1 / 2 \text { inch) } \\
\text { alternating calcisiltite \& shale bed with discontinuous bedding plane; At } 1.25 \text { ( } 1 / 8 \text { inch) mostly } \\
\text { calcisiltitic; At } 1 \text { ( } 1 \text { inch) detrital carbonate bed with discontinuous bedding plane }\end{array}$ & No \\
\hline 452 & 1412 & 61.3 & 1.1 & 4.5 & 4.5 & 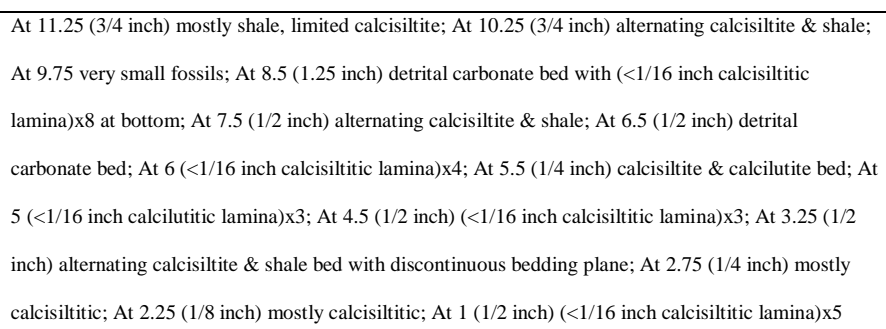 & No \\
\hline 453 & 1411 & 52.7 & 0.9 & 3.3 & 5.2 & $\begin{array}{l}\text { At } 11 \text { ( } 1 \text { inch) detrital carbonate bed with mostly calcilutite, some calcisiltite bed; At } 10.5 \text { ( } 1 / 4 \text { inch) } \\
\text { alternating calcisiltite \& shale + fossil bed; At } 8.75 \text { ( } 1 / 2 \text { inch) alternating calcisiltite \& shale; At } 8 \text { ( } 1 / 2 \\
\text { inch) mostly calcisiltitic; At } 5.75 \text { ( } 3 / 4 \text { inch) detrital carbonate bed; At } 4.25 \text { ( } 1 / 4 \text { inch) mostly } \\
\text { calcisiltitic; At } 3.75 \text { ( } 2.25 \text { inch) detrital carbonate bed; At } 3.25 \text { ( } 1 / 4 \text { inch) alternating calcisiltite \& shale; } \\
\text { At } 2.75 \text { ( } 1 / 2 \text { inch) alternating calcisiltite \& shale; At } 2.65 \text { ( }<1 / 16 \text { inch calcisiltitic lamina)x } 3 \text {; At } 2.5 \\
(1 / 16 \text { inch) calcisiltite bed; At } 1 \text { ( } 1.25 \text { inch) detrital carbonate bed with horizontal burrow at } 1 \text {; At } .5 \\
(<1 / 16 \text { inch calcilutitic lamina)x } 8\end{array}$ & No \\
\hline 454 & 1410 & 66.4 & 1.2 & 4.5 & 5.7 & $\begin{array}{l}\text { At } 11.5 \text { ( } 1.5 \text { inch) mostly shale, limited calcisiltite to alternating calcisiltite \& shale up; At } 9(<1 / 16 \\
\text { inch calcisiltitic lamina)x } 2 \text { At } 8 \text { ( } 1 / 4 \text { inch) alternating calcisiltite \& shale; At } 4.5 \text { ( } 1 / 8 \text { inch) calcisiltite } \\
\text { bed; At } 3.75 \text { alternating calcisiltite \& shale; At } 2.75 \text { ( }<1 / 16 \text { inch calcisiltitic lamina)x } 3 \text {; At } 1.75 \text { ( } 1 / 2 \\
\text { inch) alternating calcisiltite \& shale; At } .25 \text { ( } 1 / 2 \text { inch) alternating calcisiltite \& shale }\end{array}$ & No \\
\hline
\end{tabular}




\begin{tabular}{|c|c|c|c|c|c|c|c|}
\hline 455 & 1409 & 64 & 0 & 7.2 & 4.8 & $\begin{array}{l}\text { At } 10.5 \text { very small fossils; At } 9.25 \text { (1/6) calcilutite bed; At } 2.6(3 / 8 \text { inch) alternating calcisiltite } \& \text { shale; } \\
\text { At } 5.75 \text { ( } 1 \text { inch) mostly calcisiltitic + vertical burrow; At } 6(<1 / 16 \text { inch calcilutitic lamina); At } 5.25 \\
(<1 / 16 \text { inch calcilutitic lamina)x } 3 \text {; At } 4.75 \text { ( } 1 / 4 \text { inch) mostly shale, limited calcilutite bed with } \\
\text { discontinuous bedding plane; At } 4 \text { ( } 1 / 4 \text { inch) calcilutite bed; At } 0(3.5) \text { detrital carbonate bed }\end{array}$ & Yes \\
\hline 456 & 1408 & 30.9 & 0.1 & 0.7 & 7.7 & $\begin{array}{l}8 \text { to } 12 \text { missing; At } 7 \text { ( } 1 \text { inch) calcisiltite \& calcilutite bed; At } 6(<1 / 16 \text { inch calcilutitic lamina)x } 5 \text {; At } \\
3.75 \text { ( }<1 / 16 \text { inch calcisiltitic lamina)x } 3 \text {; At } 3 \text { (1/2 inch) calcisiltite bed with discontinuous bedding } \\
\text { plane; At } 1.5 \text { ( } 3 / 4 \text { inch) alternating calcisiltite \& shale }\end{array}$ & No \\
\hline 457 & 1407 & 56.2 & 1.3 & 3.4 & 4.2 & $\begin{array}{l}\text { At } 11.5 \text { (1/4 inch) mostly shale, limited calcisiltite bed with discontinuous bedding plane; At } 10.75 \text { ( } 1 / 4 \\
\text { inch) alternating calcisiltite } \& \text { shale bed with discontinuous bedding plane; At } 10 \text { ( }<1 / 16 \text { inch } \\
\text { calcilutitic lamina)x3; At } 9.75 \text { ( }<1 / 16 \text { inch calcilutitic lamina); At } 9(1 / 2 \text { inch) detrital carbonate bed; At } \\
7 \text { ( } 1 \text { inch) detrital carbonate bed with horizontal burrow?; At } 5.75 \text { ( } 1 / 2 \text { inch) alternating calcisiltite \& } \\
\text { shale + vertical burrow; At } 5.5 \text { ( }<1 / 16 \text { inch calcilutitic lamina)x3; At } 5 \text { ( } 1 / 8 \text { inch) calcisiltite bed + } \\
\text { ( }<1 / 16 \text { inch calcisiltitic lamina)x2; At } 4 \text { ( } 1 / 2 \text { inch) mostly calcisiltitic; At } 3 \text { ( } 1 \text { inch) detrital carbonate } \\
\text { bed; At } 2.75 \text { ( } 1 / 8 \text { inch) calcisiltite bed with discontinuous bedding plane; At } 1.25 \text { ( } 1 / 2 \text { inch) detrital } \\
\text { carbonate bed }\end{array}$ & Yes \\
\hline 458 & 1406 & 54.8 & 1.2 & 3 & 5.2 & $\begin{array}{l}\text { At } 11.5 \text { (1/4 inch) alternating calcisiltite \& shale; At } 11.25 \text { (1/8 inch) calcisiltite bed; At } 10.75 \text { (1/4 } \\
\text { inch) alternating calcisiltite \& shale; At } 10.25 \text { ( } 1 / 4 \text { inch) mostly calcisiltitic; At } 9.75(<1 / 16 \text { inch } \\
\text { calcisiltitic lamina)x2; At } 9.5 \text { ( } 1 / 4 \text { inch) mostly shale, limited calcisiltite bed with discontinuous } \\
\text { bedding plane; At } 9.25 \text { ( } 1 / 8 \text { inch) calcisiltite bed; At } 9 \text { ( }<1 / 16 \text { inch calcisiltitic lamina); At } 8 \text { ( } 1 / 4 \text { inch) } \\
\text { mostly shale, limited calcisiltite bed with discontinuous bedding plane; At } 7.5 \text { ( } 4.5 \text { inch) detrital } \\
\text { carbonate bed; At } 2.75 \text { ( } 1 / 4 \text { inch) mostly calcisiltitic; At } 2.25 \text { ( } 1 / 4 \text { inch) alternating calcisiltite \& shale; } \\
\text { At } 2 \text { (<1/16 inch calcisiltitic lamina)x } 5 \text {; At . } 75 \text { ( } 1 \text { inch) detrital carbonate bed; At } 0.5 \text { (1/8 inch) mostly } \\
\text { calcisiltitic; At } 0 \text { ( } 1 / 4 \text { inch) mostly calcisiltitic }\end{array}$ & No \\
\hline 459 & 1405 & 57.1 & 1.1 & 3.5 & 5.1 &  & No \\
\hline 460 & 1404 & 57.8 & 1 & 3.4 & 6 & 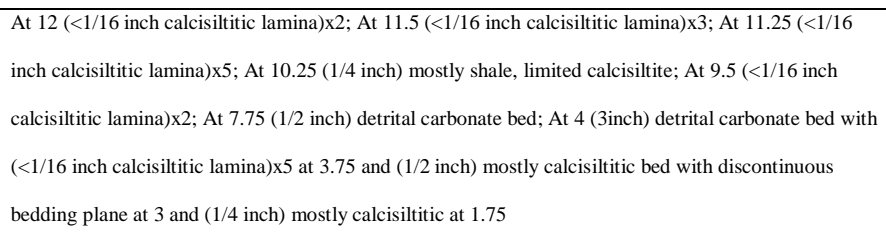 & No \\
\hline 461 & 1403 & 54.6 & 1 & 3.5 & 4.9 & $\begin{array}{l}\text { At } 11.25 \text { (1/4 inch) alternating calcisiltite \& shale bed with discontinuous bedding plane; At } 9.75 \text { ( } 3 / 4 \\
\text { inch) alternating calcisiltite \& shale with vertical burrow?; At } 9.51 / 8 \text { inch alternating calcisiltite \& } \\
\text { shale bed with discontinuous bedding plane; At } 8.75 \text { ( } 1 / 4 \text { inch) alternating calcisiltite \& shale; At } 8.25 \\
\text { ( }<1 / 16 \text { inch calcisiltitic lamina)x4; At } 5.5 \text { ( } 1.5 \text { inch) detrital carbonate bed; At } 5 \text { ( } 1 / 4 \text { inch) alternating } \\
\text { calcisiltite \& shale; At } 4 \text { ( } 1 / 2 \text { inch) mostly shale, limited calcisiltite bed with discontinuous bedding } \\
\text { plane; At } 3.75 \text { (<1/16 inch calcilutitic lamina)x4; At } 2.5 \text { ( } 3 / 8 \text { inch) calcisiltite \& calcilutite bed; At } 1.25 \\
(1 / 4 \text { inch) calcisiltite bed; At } 1 \text { ( } 1 / 8 \text { inch) mostly calcisiltitic; At } .5 \text { ( } 1 / 8 \mathrm{inch}) \text { calcilutite bed }\end{array}$ & No \\
\hline 462 & 1399 & 70.7 & 0 & 8.3 & 4.9 & $\begin{array}{l}\text { At } 11.75 \text { (1/16 inch) mostly calcisiltitic; At } 10.5 \text { ( } 1 / 2 \text { inch) mostly calcisiltitic; At } 10(<1 / 16 \text { inch } \\
\text { calcilutitic lamina)x } 2 \text {; At } 9 \text { ( } 1 / 4 \text { inch) mostly calcisiltitic; At } 7(3 / 8 \text { inch }) \text { mostly calcisiltitic; At } 5.5(1 / 4 \\
\text { inch) alternating calcisiltite \& shale; At } 5 \text { ( }<1 / 16 \text { inch calcilutitic lamina)x4; At } 4 \text { ( } 1 / 4 \text { inch) alternating } \\
\text { calcisiltite \& shale; At } 4 \text { ( } 4 \text { inch) detrital carbonate bed }\end{array}$ & No \\
\hline
\end{tabular}




\begin{tabular}{|c|c|c|c|c|c|c|c|}
\hline 463 & 1398 & 51.7 & 0.8 & 3.5 & 4.7 & $\begin{array}{l}\text { At } 12 \text { ( } 2.5 \text { inch) detrital carbonate bed; At } 8 \text { ( } 1 / 2 \text { inch) mostly shale, limited calcisiltite; At } 6 \text { ( } 1.5 \text { inch) } \\
\text { detrital carbonate bed; At } 5.5 \text { ( }<1 / 16 \text { inch calcilutitic lamina); At } 4.5 \text { (1/8 inch) calcilutite bed; At } 4 \text { (1/8 } \\
\text { inch) calcisiltite bed with discontinuous bedding plane; At } 3 \text { ( } 1 / 4 \text { inch) alternating calcisiltite } \& \text { shale; } \\
\text { At } 2.5 \text { (<1/16 inch calcilutitic lamina)x } 2 \text {; At } 2.25 \text { (1/10) mostly shale, limited calcisiltite; At } 1.75 \text { (1/16 } \\
\text { inch) calcisiltite bed with discontinuous bedding plane; At } 1.5(<1 / 16 \text { inch calcisiltitic lamina); At } 1 \\
\text { (1/2 inch) bed with discontinuous bedding plane mostly calcisiltitic }\end{array}$ & No \\
\hline 464 & 1397 & 42.7 & 0.7 & 2.4 & 4.6 & $\begin{array}{l}\text { At } 10.25 \text { (1.5 inch) detrital carbonate bed; At } 10 \text { (1/16 inch) calcisiltite bed; At } 9.75(1 / 10) \text { calcilutite } \\
\text { bed with discontinuous bedding plane; At } 9 \text { (1/16 inch) calcilutite bed; At } 9 \text { ( } 6 \text { inches })(<1 / 16 \text { inch } \\
\text { calcisiltitic lamina) } 5 \text { + ( } 1 / 4 \text { inch) calcisiltite lamina x } 5 \text {; At } 3 \text { ( } 3 \text { inch) detrital carbonate bed }\end{array}$ & No \\
\hline 465 & 1396 & 55 & 1 & 3.2 & 5.4 & $\begin{array}{l}\text { At } 11.5 \text { ( } 1 / 2 \text { inch) detrital carbonate bed; At } 9.25 \text { ( } 3 / 4 \text { inch) alternating calcisiltite \& shale bed with } \\
\text { discontinuous bedding plane; At } 8.25 \text { ( } 1 / 16 \text { inch) calcisiltite lamina x } 2 \text {; At } 7 \text { (1/2 inch) mostly shale, } \\
\text { limited calcisiltite; At } 5 \text { ( } 1.5 \text { inch) calcisiltite \& calcilutite bed; At } 4.75 \text { ( } 1 / 16 \text { inch) calcisiltite bed; At } \\
4.5 \text { ( }<1 / 16 \text { inch calcisiltitic lamina)x } 3 \text {; At } 3.75 \text { ( } 3.75 \text { inch) shale to calcisiltite up }\end{array}$ & No \\
\hline 466 & 1395 & 49.9 & 0.9 & 3.2 & 4.3 & $\begin{array}{l}\text { At } 10 \text { (1.5 inch) mostly calcisiltitic; At } 9.75 \text { (1/4 inch) mostly calcilutitic; At } 9.5 \text { (<1/16 inch calcilutitic } \\
\text { lamina); At } 8.5 \text { (1/2 inch) mostly shale, limited calcisiltite; At } 4.75 \text { (1/8 inch) mostly calcisiltitic; At } 4 \\
\text { fossils; At } 3 \text { small fossils; At } 2(<1 / 16 \text { inch calcisiltitic lamina) } 2 \text {; At } 1(1 / 10) \text { mostly calcisiltitic; At } 0 \\
(<1 / 16 \text { inch calcilutitic lamina) }\end{array}$ & No \\
\hline 467 & 1394 & 61.7 & 0.8 & 4.1 & 6.7 & $\begin{array}{l}\text { At } 11 \text { (1/2 inch) alternating calcisiltite \& shale; At } 10 \text { (1/8 inch) calcisiltite bed; At } 9.5(<1 / 16 \text { inch } \\
\text { calcilutitic lamina); At } 9 \text { (1/4 inch) mostly calcisiltitic; At } 8.5(<1 / 16 \text { inch calcisiltitic lamina); At } 8 \\
\text { ( }<1 / 16 \text { inch calcisiltitic lamina); At } 6 \text { ( } 3 / 4 \text { inch) alternating calcisiltite \& shale; At } 3 \text { (1/16 inch) } \\
\text { calcisiltite bed; At } 1 \text { ( }<1 / 16 \text { inch calcilutitic lamina)x } 2 \text {; At } 0(<1 / 16 \text { inch calcisiltitic lamina) }\end{array}$ & No \\
\hline 468 & 1393 & 56.1 & 1.1 & 3 & 6.1 & $\begin{array}{l}\text { At } 10.5 \text { ( } 1 \text { inch) mostly shale, limited calcisiltite; At } 10.5 \text { ( } 3 \text { inch) detrital carbonate bed + fossils at top; } \\
\text { At } 7 \text { ( } 2 \text { inch) bentonite; At } 3(1 / 4 \text { inch) bentonite; At } 2(<1 / 16 \text { inch calcisiltitic lamina }) \times 2 \text {; At } .5 \text { ( } 1 \text { inch }) \\
\text { detrital carbonate bed }\end{array}$ & No \\
\hline 469 & 1392 & 52.5 & 0.9 & 3.9 & 3.8 & $\begin{array}{l}\text { At } 9.5 \text { ( } 3.5 \text { inch) detrital carbonate bed; At } 5 \text { (1/4 inch) mostly shale, limited calcisiltite; At } 3.5 \text { (1/2 } \\
\text { inch) alternating calcisiltite \& shale; At } 2.5 \text { fossils; At } 2 \text { ( } 1 / 2 \mathrm{inch}) \text { detrital carbonate bed; At } 1.5 \text { (1/4 } \\
\text { inch) } \mathrm{M}+(<1 / 16 \text { inch calcisiltitic lamina)x } 4 \text {; At .5 ( } 1 / 2 \mathrm{inch}) \text { detrital carbonate bed; At } 0(1 / 4 \mathrm{inch}) \\
\text { mostly shale, limited calcisiltite }\end{array}$ & No \\
\hline 470 & 1391 & 50.4 & 1 & 3.1 & 4.5 & $\begin{array}{l}\text { At } 11.25 \text { small fossils; At } 11 \text { ( }<1 / 16 \text { inch calcilutitic lamina); At } 10.75 \text { ( }<1 / 16 \text { inch calcilutitic lamina); } \\
\text { At } 10.5 \text { (1/10) calcilutite bed with discontinuous bedding plane; At } 8.5 \text { (1/4 inch) mostly shale, limited } \\
\text { calcisiltite; At } 7.75 \text { ( } 1 / 4 \text { inch) alternating calcisiltite \& shale; At } 6.75 \text { (1/10) mostly calcilutitic; At } 6.5 \\
\text { ( }<1 / 16 \text { inch calcilutitic lamina); At } 6 \text { (1/2 inch) mostly shale, limited calcisiltite; At } 5 \text { ( }<1 / 16 \text { inch } \\
\text { calcisiltitic lamina)x4; At } 3.75 \text { ( } 1 / 4 \text { inch) mostly shale, limited calcisiltite bed with discontinuous } \\
\text { bedding plane; At } 3 \text { ( } 1 / 2 \text { inch) mostly calcisiltitic bed with discontinuous bedding plane; At } 2.5 \text { ( } 1 / 4 \\
\text { inch) mostly shale, limited calcisiltite; At } 2(<1 / 16 \text { inch calcisiltitic lamina)x } 2 \text {; At } 1.5 \text { ( } 1 / 4 \text { inch) mostly } \\
\text { shale, limited calcisiltite }\end{array}$ & No \\
\hline 471 & 1390 & 63.1 & 0.8 & 4.9 & 5.3 & $\begin{array}{l}\text { At } 11.75 \text { trilobite; At } 11.5 \text { (1/10) mostly calcilutitic; At } 10.75 \text { small trilobite; At } 10 \text { (1/4 inch) } \\
\text { alternating calcisiltite \& shale; At } 8.5 \text { (1/4 inch) mostly shale, limited calcisiltite; At } 6.5(1 / 16 \text { inch) } \\
\text { calcisiltite bed + (<1/16 inch calcisiltitic lamina); At } 3.5 \text { ( } 1 / 4 \text { inch) bentonite; At } 3(1 / 10) \text { calcisiltite bed } \\
\text { with discontinuous bedding plane; At } 2.5 \text { fossil bed; At } 2(1 / 16 \text { inch) calcilutite bed; At } 1(<1 / 16 \text { inch } \\
\text { calcilutitic lamina) }\end{array}$ & No \\
\hline
\end{tabular}




\begin{tabular}{|c|c|c|c|c|c|c|c|}
\hline 472 & 1389 & 45.6 & 0.9 & 2.8 & 4 & 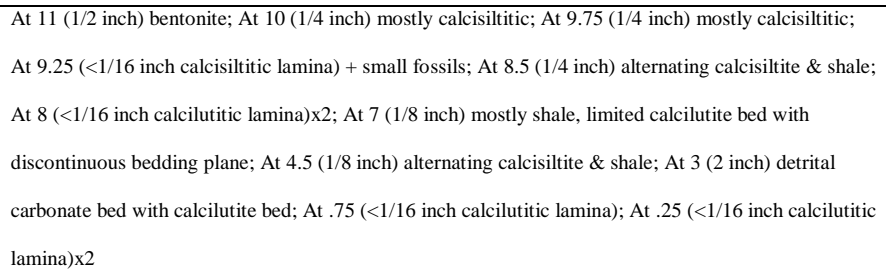 & No \\
\hline 473 & 1388 & 54.3 & 1.1 & 2.7 & 5.8 & $\begin{array}{l}\text { At } 12 \text { (1/16 inch) calcisiltite bed; At } 11.5 \text { fossils + (1/8 inch) calcilutite bed; At } 10.5 \text { (1/2 inch) mostly } \\
\text { shale, limited calcisiltite + fossils; At } 10 \text { fossil bed; At } 9.75 \text { ( }<1 / 16 \text { inch calcilutitic lamina); At } 8.25 \\
\text { (1.25 inch) detrital carbonate bed; At } 6.75 \text { ( } 1 \text { inch) calcisiltite to calcilutite up; At } 5 \text { ( }<1 / 16 \text { inch } \\
\text { calcilutitic lamina); At } 4.25 \text { ( } 1 \text { inch) alternating calcisiltite \& shale; At } 2 \text { trilobite; At . } 75 \text { calcilutite bed } \\
\text { with discontinuous bedding plane + fossils }\end{array}$ & No \\
\hline 474 & 1387 & 62.7 & 1.2 & 3.9 & 5.8 & $\begin{array}{l}\text { At } 11.75 \text { (1/4 inch) mostly calcilutitic bed with discontinuous bedding plane; At } 8 \text { (1/2 inch) mostly } \\
\text { calcilutitic; At } 7 \text { (1/4 inch) alternating calcisiltite \& shale; At } 6.25(1 / 10) \text { calcilutite bed; At } 5 \text { (1/2 inch) } \\
\text { alternating calcisiltite \& shale; At } 5 \text { ( } 3 \text { inch) detrital carbonate bed with internal lamination; At } 1.5 \\
(<1 / 16 \text { inch calcilutitic lamina); At } 1(<1 / 16 \text { inch calcilutitic lamina)x } 2\end{array}$ & No \\
\hline 475 & 1386 & 55.4 & 0.9 & 3.3 & 5.9 & $\begin{array}{l}\text { At } 10.75 \text { (1/4 inch) alternating calcisiltite \& shale; At } 10.5(1 / 10) \text { calcilutite bed with discontinuous } \\
\text { bedding plane; At } 9 \text { ( } 1 / 4 \text { inch) calcisiltite bed + fossils; At } 8.5(<1 / 16 \text { inch calcisiltitic lamina)x } 5 \text {; At } 8 \\
\text { ( }<1 / 16 \text { inch calcisiltitic lamina); At } 7 \text { ( } 1 / 2 \text { inch) mostly shale, limited calcisiltite bed with discontinuous } \\
\text { bedding plane + fossils; At } 6 \text { ( } 1 / 4 \text { inch) mostly calcisiltitic bed with discontinuous bedding plane; At } \\
5.75 \text { (<1/16 inch calcisiltitic lamina)x3; At } 4.75 \text { ( }<1 / 16 \text { inch calcisiltitic lamina)x3; At } 3 \text { (1/4 inch) } \\
\text { mostly calcisiltitic bed with discontinuous bedding plane; At } 1.25 \text { ( } 1 / 4 \text { inch) calcisiltite bed with } \\
\text { discontinuous bedding plane }\end{array}$ & No \\
\hline 476 & 1385 & 53.7 & 0.9 & 3.8 & 4.3 & $\begin{array}{l}\text { At } 12 \text { ( } 1.5 \text { inch) calcisiltite to shale up; At } 10 \text { ( } 1 / 2 \text { inch) calcisiltite \& calcilutite bed; At } 9 \text { (1/2 inch) } \\
\text { mostly calcilutite bed with discontinuous bedding plane; At } 8.5 \text { fossils; At } 8 \text { fossils; At } 7.25 \text { fossils; At } \\
7 \text { ( } 1 / 8 \text { inch) mostly calcilutitic; At } 6.5 \text { ( } 1 / 2 \text { inch) mostly shale, limited calcilutite bed with discontinuous } \\
\text { bedding plane; At } 5 \text { fossil bed; At } 4 \text { fossil bed; At } 2.5 \text { ( } 1 / 2 \text { inch) mostly calcilutitic bed with } \\
\text { discontinuous bedding plane at top; At } 1 \text { ( } 1 / 4 \text { inch) calcisiltite bed with discontinuous bedding plane; At } \\
.5 \text { ( }<1 / 16 \text { inch calcilutitic lamina) } 3\end{array}$ & No \\
\hline 477 & 1384 & 56.6 & 1.2 & 2.8 & 6 & $\begin{array}{l}\text { At } 11.75 \text { (1/10) calcisiltite bed + fossils; At } 11.5 \text { ( }<1 / 16 \text { inch calcisiltitic lamina); At } 11 \text { ( }<1 / 16 \text { inch } \\
\text { calcisiltitic lamina); At } 10 \text { ( }<1 / 16 \text { inch calcisiltitic lamina)x3; At } 9 \text { (1/2 inch) mostly calcisiltitic bed } \\
\text { with discontinuous bedding plane at top; At } 7 \text { ( } 5 \text { inch) detrital carbonate bed with ripple lamination } \\
\text { apparent throughout to alternating calcisiltite \& shale at top; At } 1.5(1 / 4 \text { inch) mostly shale, limited } \\
\text { calcisiltite bed with discontinuous bedding plane; At } 0(1 / 2 \mathrm{inch}) \text { mostly calcisiltitic }\end{array}$ & No \\
\hline 478 & 1383 & 51.5 & 1 & 3.4 & 4 & $\begin{array}{l}\text { At } 11.5(1 / 10) \text { calcilutite bed with discontinuous bedding plane; At } 11 \text { (<1/16 inch calcilutitic lamina); } \\
\text { At } 10.5(<1 / 16 \text { inch calcilutitic lamina })+\text { fossils; At } 10(2 \mathrm{inch}) \text { small fossils; At } 7.5(<1 / 16 \text { inch } \\
\text { calcilutitic lamina)x } 2 \text {; At } 6.5(<1 / 16 \text { inch calcilutitic lamina })+(1 / 10) \text { calcisiltite bed with discontinuous } \\
\text { bedding plane; At } 4.5 \text { ( } 1 / 4 \text { inch) alternating calcisiltite \& shale; At } 2.5(1 \mathrm{inch}) \text { mostly calcisiltitic up; } \\
\text { At } 2(1 / 4 \text { inch) alternating calcisiltite \& shale bed with discontinuous bedding plane; At } 1 \text { small fossils }\end{array}$ & No \\
\hline 479 & 1382 & 56.2 & 0.9 & 3.6 & 5.4 & $\begin{array}{l}\text { At } 10.5 \text { (1/2 inch) mostly calcisiltitic; At } 10 \text { (1/10) mostly calcisiltitic; At } 9 \text { (1/4 inch) alternating } \\
\text { calcisiltite \& shale; At } 8.5 \text { (<1/16 inch calcilutitic lamina)x } 3 \text {; At } 7.5 \text { ( } 1 / 8 \text { inch) calcilutite bed with } \\
\text { discontinuous bedding plane; At } 7.25 \text { (1/16 inch) calcisiltite lamina x } 2 \text {; At } 5.5 \text { fossil bed; At } 1.25 \text { fossil } \\
\text { bed; At } .5 \text { fossils }\end{array}$ & No \\
\hline
\end{tabular}




\begin{tabular}{|c|c|c|c|c|c|c|c|}
\hline 480 & 1381 & 63.6 & 1.2 & 3.7 & 6.4 & $\begin{array}{l}\text { At } 10 \text { (1/2 inch) calcisiltite to shale up; At } 9.5 \text { fossils + (1/2 inch) calcisiltite to shale up; At } 7(<1 / 16 \\
\text { inch calcilutitic lamina)x6; At } 6.5 \text { (1/16 inch) calcilutite bed with discontinuous bedding plane; At } 5.5 \\
(1 / 10) \text { calcilutite bed with discontinuous bedding plane; At } 5.25(1 / 10) \text { calcilutite bed with } \\
\text { discontinuous bedding plane; At } 4.5(<1 / 16 \text { inch calcilutitic lamina)x } 8 \text {; At } 3(<1 / 16 \text { inch calcisiltitic } \\
\text { lamina)x } 2\end{array}$ & No \\
\hline 481 & 1380 & 47.7 & 0.9 & 2.8 & 4.6 & $\begin{array}{l}\text { At } 11 \text { ( } 1 \text { inch) mostly shale, limited calcilutite; At } 10.25 \text { ( }<1 / 16 \text { inch calcilutitic lamina); At } 8.75(<1 / 16 \\
\text { inch calcilutitic lamina); At } 8 \text { ( }<1 / 16 \text { inch calcilutitic lamina); At } 7.5 \text { ( }<1 / 16 \text { inch calcilutitic lamina); At } \\
7 \text { (1/16 inch) calcilutite bed with discontinuous bedding plane; At } 6 \text { trilobite; At } 5 \text { fossil bed; At } 4.5 \\
\text { ( }<1 / 16 \text { inch calcilutitic lamina); At } 4 \text { fossil bed; At } 3.25 \text { ( }<1 / 16 \text { inch calcisiltitic lamina); At } 2 \text { ( } 3 / 4 \text { inch) } \\
\text { calcisiltite to shale up + calcisiltite at top ( } 1 / 8 \text { inch); At } 1.5 \text { ( } 1 / 2 \text { inch) alternating calcisiltite \& shale }\end{array}$ & No \\
\hline 482 & 1379 & 49 & 1 & 2.9 & 4.1 & $\begin{array}{l}\text { At } 12 \text { ( } 2.5 \text { inch) alternating calcisiltite \& shale with discontinuous bedding plane; At } 8.5 \text { (1/2 inch) } \\
\text { alternating calcisiltite \& shale bed with discontinuous bedding plane; At } 7 \text { (1/10) calcisiltite bed with } \\
\text { discontinuous bedding plane; At } 6.5(1 / 10) \text { calcisiltite bed; At } 5.5(1 / 10) \text { calcisiltite bed with } \\
\text { discontinuous bedding plane; At } 5 \text { ( }<1 / 16 \text { inch calcisiltitic lamina)x3; At } 4.5 \text { small fossils; At } 2.5 \text { ( } 1 \\
\text { inch) mostly shale, limited calcisiltite + calcisiltite bed with discontinuous bedding plane at top; At } 1 \\
\text { big trilobite about } .75 \text { inch wide; At } .5 \text { ( } 1 / 16 \text { inch) calcilutite }\end{array}$ & No \\
\hline 483 & 1378 & 56.3 & 1.2 & 3.3 & 4.7 & $\begin{array}{l}\text { At } 10.5 \text { (1/4 inch) calcilutite bed with discontinuous bedding plane; At } 9(1 / 4 \text { inch }) \text { calcisiltite bed; At } 9 \\
\text { ( } 3 \text { inch) alternating calcisiltite } \& \text { shale ripple lamination some bed with discontinuous bedding plane; } \\
\text { At } 5 \text { ( }<1 / 16 \text { inch calcisiltitic lamina); At } 4.5 \text { ( } 1.3 \text { inch) }(<1 / 16 \text { inch calcilutitic lamina)x } 8 \text {; At } 2(1 / 4 \\
\text { inch) mostly calcilutitic; At } 0(1 \mathrm{inch}) \text { mostly shale, limited calcisiltite bed with discontinuous bedding } \\
\text { plane }\end{array}$ & No \\
\hline 484 & 1377 & 63.6 & 1 & 4 & 6.5 & $\begin{array}{l}\text { At } 11 \text { ( } 1 / 2 \text { inch) calcisiltite bed with pyrite; At } 9.5 \text { ( } 3 / 4 \text { inch) mostly shale, limited calcisiltite thin } \\
\text { laminae; At } 6.5 \text { ( } 1 / 8 \text { inch) calcilutite bed with discontinuous bedding plane + small fossils; At } 5.5 \text { (1/2 } \\
\text { inch) mostly shale, limited calcisiltite; At } 4.5 \text { ( } 1 / 4 \text { inch) mostly shale, limited calcisiltite; At } 4.25(<1 / 16 \\
\text { inch calcisiltitic lamina)x } 3 \text {; At } 3.5 \text { ( } 1 / 2 \text { inch) mostly shale, limited calcisiltite; At } 2.5 \text { ( }<1 / 16 \text { inch } \\
\text { calcilutitic lamina)x4; At } 1 \text { ( } 3 / 4 \text { inch) alternating calcisiltite \& shale thin laminae }\end{array}$ & No \\
\hline 485 & 1376 & 55.9 & 1 & 3.6 & 5 & $\begin{array}{l}\text { At } 12 \text { (<1/16 inch calcisiltitic lamina); At } 11 \text { ( }<1 / 16 \text { inch calcisiltitic lamina)x3; At } 8 \text { fossils; At } 7.5(1 / 8 \\
\text { inch) mostly calcisiltitic; At } 6 \text { trilobites; At } 4.5 \text { ( } 1 / 4 \text { inch) mostly shale, limited calcilutite; At } 3 \text { (1/2 } \\
\text { inch) alternating calcisiltite } \& \text { shale bed with discontinuous bedding plane; At } 2.5(1 / 16 \text { inch) calcilutite } \\
\text { bed; At . } 75 \text { ( }<1 / 16 \text { inch calcisiltitic lamina); At . } 5(1 / 4 \text { inch) alternating calcisiltite \& shale }\end{array}$ & No \\
\hline 486 & 1375 & 64 & 1.2 & 3.7 & 6.3 & $\begin{array}{l}\text { At } 10.5 \text { ( }<1 / 16 \text { inch calcisiltitic lamina); At } 10 \text { ( }<1 / 16 \text { inch calcisiltitic lamina })+ \text { small fossils; At } 9 \\
\text { small fossils; At } 7 \text { ( }<1 / 16 \text { inch calcilutitic lamina); At } 6.75 \text { (1/4 inch) mostly calcilutitic; At } 6(<1 / 16 \\
\text { inch calcisiltitic lamina)x3; At } 4 \text { ( }<1 / 16 \text { inch calcilutitic lamina); At } 1.5(1 / 4 \text { inch }) \text { mostly shale, limited } \\
\text { calcilutite bed with discontinuous bedding plane; At } 1(1 / 16 \mathrm{inch}) \mathrm{M}\end{array}$ & No \\
\hline 487 & 1374 & 49.9 & 1.1 & 2.2 & 5.4 & $\begin{array}{l}\text { At } 10.5 \text { (1/16 inch) calcisiltite bed with discontinuous bedding plane x2; At } 8 \text { ( }<1 / 16 \text { inch calcilutitic } \\
\text { lamina); At } 7 \text { ( } 1 / 16 \text { inch) calcisiltite bed with discontinuous bedding plane; At } 6 \text { small fossils; At } 5 \\
\text { small fossils; At } 3.5 \text { small fossils; At } 1.5 \text { fossils; At } .5 \text { fossils }\end{array}$ & No \\
\hline 488 & 1373 & 51.9 & 1 & 3.5 & 4.1 & $\begin{array}{l}\text { At } 9.75 \text { (1/4 inch) calcilutite bed; At } 8 \text { (1/4 inch) mostly calcisiltitic; At } 7 \text { fossils; At } 0(<1 / 16 \text { inch } \\
\text { calcilutitic lamina); Very organic rich interval? }\end{array}$ & No \\
\hline 489 & 1372 & 57.6 & 1 & 3.3 & 6.2 & $\begin{array}{l}\text { At } 11 \text { (1/4 inch) fossil bed; At } 10.5 \text { ( }<1 / 16 \text { inch calcisiltitic lamina); At } 9.5 \text { small fossil bed; At } 6 \text { fossil } \\
\text { bed + ( } 1 / 4 \text { inch calcilutite bed with discontinuous bedding plane; At } 5 \text { ( } 1 / 16 \text { inch) calcilutite bed with } \\
\text { discontinuous bedding plane; At } 3.5 \text { ( }<1 / 16 \text { inch calcilutitic lamina); At } 3 \text { trilobite; At } 1 \text { ( }<1 / 16 \text { inch } \\
\text { calcisiltitic lamina) }\end{array}$ & No \\
\hline
\end{tabular}




\begin{tabular}{|c|c|c|c|c|c|c|c|}
\hline 490 & 1371 & 53.9 & 0.9 & 3.5 & 4.9 & $\begin{array}{l}\text { At } 10.5 \text { (1/2 inch) calcisiltite bed with pyrite; At } 9.5 \text { (1/4 inch) calcisiltite \& calcilutite bed with } \\
\text { discontinuous bedding plane; At } 8.75 \text { (1/10) alternating calcisiltite \& shale; At } 8 \text { small fossils; At } 6 \text { (1/4 } \\
\text { inch) alternating calcisiltite \& shale; At } 3.5 \text { (1/2 inch) mostly calcilutitic; At } 2 \text { (1/4 inch) alternating } \\
\text { calcisiltite \& shale }\end{array}$ & No \\
\hline 491 & 1370 & 47.4 & 1.1 & 2.4 & 4.3 & $\begin{array}{l}\text { At } 10.5 \text { (1/4 inch) alternating calcisiltite \& shale bed with discontinuous bedding plane; At } 9.5 \text { (1/10) } \\
\text { alternating calcisiltite \& shale; At } 8 \text { ( }<1 / 16 \text { inch calcilutitic lamina); At } 7.5 \text { small fossils; At } 6(1 / 16 \\
\text { inch) calcilutite bed with discontinuous bedding plane; At } 5 \text { (1/16 inch) calcisiltite bed; At } 4 \text { mostly } \\
\text { shale, limited calcisiltite bed with discontinuous bedding plane; At } .5 \text { (1/4 inch) mostly shale, limited } \\
\text { calcilutite bed with discontinuous bedding plane }\end{array}$ & No \\
\hline 492 & 1369 & 54.9 & 1.3 & 2.5 & 5.5 & $\begin{array}{l}\text { At } 11.5 \text { (<1/16 inch calcilutitic lamina); At } 11.25 \text { ( }<1 / 16 \text { inch calcisiltitic lamina) bed with } \\
\text { discontinuous bedding plane; At } 8.25 \text { (1/2 inch) alternating calcisiltite \& shale; At } 6 \text { (1/4 inch) mostly } \\
\text { shale, limited calcilutite bed with discontinuous bedding plane; At } 4 \text { ( } 1 / 4 \text { inch) mostly shale, limited } \\
\text { calcisiltite; At } 3 \text { ( } 1 / 4 \text { inch) alternating calcisiltite \& shale ver bed with discontinuous bedding plane; At } \\
1 \text { (1/2 inch) alternating calcisiltite \& shale bed with discontinuous bedding plane }\end{array}$ & No \\
\hline 493 & 1368 & 56.4 & 1.1 & 3.3 & 5.3 & $\begin{array}{l}\text { At } 8.5 \text { (1/4 inch) mostly calcisiltitic bed with discontinuous bedding plane with pyrite in the calcisiltite } \\
\text { bed; At } 6.5(1 / 10) \text { mostly shale, limited calcilutite; At } 4(1 / 10) \text { calcilutite bed with discontinuous } \\
\text { bedding plane; At } 3.5(1 / 16 \text { inch) M }\end{array}$ & No \\
\hline 494 & 1367 & 52 & 1.1 & 3.5 & 3.7 & $\begin{array}{l}\text { At } 10 \text { (1/2 inch) calcilutite bed; At } 9 \text { (1/2 inch) alternating calcisiltite \& shale bed with discontinuous } \\
\text { bedding plane; At } 7 \text { (1/16 inch) calcisiltite bed with discontinuous bedding plane; At } 5.5 \text { (1/2 inch) } \\
\text { calcilutite to shale up; At } 4.5 \text { (<1/16 inch calcilutitic lamina); At } 4 \text { (1/8 inch) alternating calcisiltite \& } \\
\text { shale; At } 3 \text { ( } 1 / 4 \text { inch) mostly calcisiltitic bed with discontinuous bedding plane; At .75 (1/16 inch) M + } \\
\text { trilobite }\end{array}$ & No \\
\hline 495 & 1366 & 51 & 1.2 & 2.2 & 5.3 & $\begin{array}{l}\text { At } 8 \text { trilobite; At } 6.5 \text { (1/4 inch) alternating calcisiltite \& shale; At } 4.5 \text { ( }<1 / 16 \text { inch calcilutitic lamina); } \\
\text { At } 2.25 \text { (1/4 inch) mostly calcisiltitic; At } 0 \text { fossil }\end{array}$ & No \\
\hline 496 & 1365 & 58.8 & 1.1 & 3.6 & 5.7 & $\begin{array}{l}\text { At } 11 \text { (1/2 inch) calcisiltite \& calcilutite bed with discontinuous bedding plane at base; At } 9.5 \text { (1/10) } \\
\text { alternating calcisiltite \& shale; At } 8.5 \text { (1/10) calcisiltite bed with discontinuous bedding plane; At } 6.5 \\
\text { (1/4 inch) alternating calcisiltite \& shale; At } 4.5 \mathrm{~L}<\text { calcilutite bed with discontinuous bedding plane; At } \\
3.5 \text { (<1/16 inch calcilutitic lamina) } 3 \text {; At } 3(1 / 16 \text { inch) M }\end{array}$ & No \\
\hline 497 & 1364 & 45.5 & 1.2 & 2.4 & 3.5 & $\begin{array}{l}\text { At } 8.5 \text { (1/4 inch) mostly shale, limited calcisiltite; At } 7.5 \text { ( }<1 / 16 \text { inch calcisiltitic lamina); At } 4 \text { (1/8 } \\
\text { inch) mostly calcilutitic bed with discontinuous bedding plane; At } 4 \text { (1/2 inch) }(<1 / 16 \text { inch calcilutitic } \\
\text { lamina)x4; At } 2.75 \text { ( } 1 / 16 \text { inch) M }\end{array}$ & No \\
\hline 498 & 1363 & 61.5 & 1 & 4 & 5.7 & $\begin{array}{l}\text { At } 11.5 \text { (1/8 inch) mostly shale, limited calcilutite; At } 10.5 \text { (1/4 inch) mostly shale, limited calcisiltite; } \\
\text { At } 9 \text { ( } 1 / 2 \text { inch) calcilutite to shale up; At } 7(1 / 16 \text { inch }) \text { calcisiltite bed with discontinuous bedding plane; } \\
\text { At } 6.75 \text { ( } 1 / 4 \text { inch) calcisiltite bed with discontinuous bedding plane with pyrite; At } 5.5(1 / 10) \text { mostly } \\
\text { shale, limited calcisiltite; At } 4(1 / 10) \text { calcisiltite bed with discontinuous bedding plane; At } 3(<1 / 16 \text { inch } \\
\text { calcisiltitic lamina) bed with discontinuous bedding plane; At } 1.75(1 / 10) \text { calcisiltite bed with } \\
\text { discontinuous bedding plane; At } 1(<1 / 16 \text { inch calcisiltitic lamina); At } .75(<1 / 16 \text { inch calcisiltitic } \\
\text { lamina) }\end{array}$ & No \\
\hline 499 & 1362 & 55.5 & 0.9 & 4.5 & 3.5 & $\begin{array}{l}\text { At } 11.5 \text { (1/2 inch) alternating calcisiltite \& shale bed with discontinuous bedding plane; At } 8 \text { (1/4 inch) } \\
\text { mostly calcilutite, some calcisiltite bed; At } 3 \text { ( }<1 / 16 \text { inch calcisiltitic lamina); At .5 (1/4 inch) } \\
\text { alternating calcisiltite \& shale }\end{array}$ & No \\
\hline 500 & 1361 & 53.6 & 1 & 3.5 & 4.7 & $\begin{array}{l}\text { At } 11 \text { (1/16 inch) calcilutite bed; At } 10 \text { vein hair thin at } 5 \text { degrees; At } 8 \text { (1/16 inch) calcilutite bed; At } 7 \\
\text { horizontal hair vein; At } 5 \text { ( }<1 / 16 \text { inch calcilutitic lamina); At } 1 \text { (1/16 inch) calcilutite bed; At .25 (1/16 } \\
\text { inch) mostly calcisiltitic }\end{array}$ & No \\
\hline
\end{tabular}




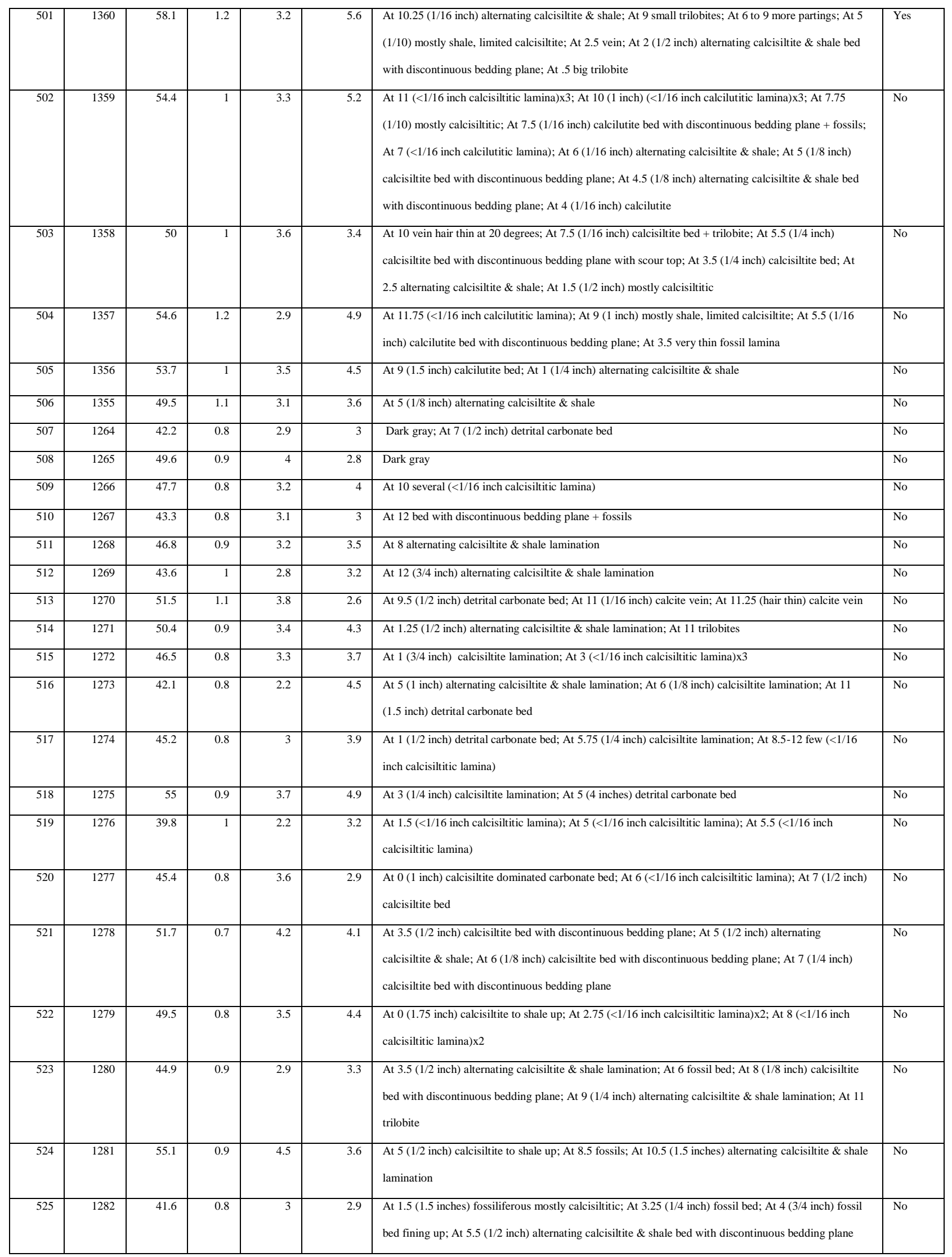









\begin{tabular}{|c|c|c|c|c|c|c|c|}
\hline 553 & 1310 & 55.8 & 0.1 & 6.4 & 3.8 & $\begin{array}{l}\text { At } 0 \text { (1/2 inch) mostly calcilutitic lamination; At } 5.75 \text { (1/4 inch) calcilutite lamination; At } 9 \text { (1/4 inch) } \\
\text { calcilutite lamination }\end{array}$ & No \\
\hline 554 & 1311 & 47.5 & 0.9 & 3.2 & 4 & At 2 (1 inch) bentonite; Dark & No \\
\hline 555 & 1312 & 46.4 & 0.8 & 3.4 & 3.6 & $\begin{array}{l}\text { At } 1 \text { trilobite; At 10(1/4 inch) alternating calcisiltite \& shale lamination; At } 12 \text { (1/4 inch) bed with } \\
\text { discontinuous bedding plane }\end{array}$ & No \\
\hline 556 & 1313 & 49.7 & 0.8 & 3.7 & 3.9 & At 8 trilobite; At 10.5 few calcilutite bed with discontinuous bedding plane & No \\
\hline 557 & 1314 & 52.6 & 1 & 3.7 & 3.9 & At 1.25 trilobite; Dark & No \\
\hline 558 & 1315 & 45.6 & 0.9 & 2.5 & 4.9 & $\begin{array}{l}\text { At } 4 \text { fossil bed; At } 5.5 \text { trilobite; At } 9 \text { (1/8 inch) calcilutite bed with discontinuous bedding plane; At } \\
10.5 \text { ( } 1 / 8 \text { inch) calcilutite bed with discontinuous bedding plane; At } 11 \text { (1/4 inch) calcilutite bed with } \\
\text { discontinuous bedding plane }\end{array}$ & No \\
\hline 559 & 1316 & 39 & 0.5 & 3.1 & 3.2 & $\begin{array}{l}\text { At } .5 \text { (1/4 inch) calcilutite lamination; At } 3.5 \text { (1/4 inch) alternating calcisiltite \& shale lamination; At } \\
9.5 \text { fossil }\end{array}$ & No \\
\hline 560 & 1317 & 45.9 & 1 & 2.9 & 3.5 & Dark; few (<1/16 inch calcilutitic lamina) & No \\
\hline 561 & 1318 & 42.6 & 0.7 & 3.2 & 3 & $\begin{array}{l}\text { At .5 (1/8 inch) calcilutite bed with discontinuous bedding plane + small fossils; At } 1.5 \text { (1/8 inch) } \\
\text { alternating calcisiltite \& shale lamination; At } 3.5 \text { pyrite; At } 4.5(1 \mathrm{inch}) \text { calcilutite bed with } \\
\text { discontinuous bedding plane; small trilobites throughout }\end{array}$ & No \\
\hline 562 & 1319 & 38.5 & 0.7 & 2.6 & 3.1 & At 0 fossil bed; At 1.5 ( $1 / 8$ inch) fossil bed; At 8.5 ( $1.5 \mathrm{inch})$ calcilutite dominated carbonate bed & No \\
\hline 563 & 1320 & 44 & 0.9 & 3 & 3.3 & $\begin{array}{l}\text { At } 3 \text { (1/8 inch) calcilutite bed with discontinuous bedding plane + trilobite; At } 6 \text { small trilobites; At } 7.5 \\
\text { small trilobites; At } 11 \text { ( } 1 / 2 \text { inch) bentonite }\end{array}$ & No \\
\hline 564 & 1321 & 48.2 & 0.8 & 2.9 & 5.2 & At 11.5 crinoid stems & No \\
\hline 565 & 1322 & 43.5 & 0.7 & 2.8 & 4.1 & $\begin{array}{l}\text { At } 1.5 \text { ( } 1 / 2 \text { inch) small fossils; At } 2.25 \text { ( } 1.75 \text { inches) small fossil beds; At } 8.25 \text { calcilutite bed with } \\
\text { discontinuous bedding plane; At } 9 \text { small trilobite }\end{array}$ & No \\
\hline 566 & 1324 & 49.1 & 0.9 & 3.7 & 3.3 & Few small fossils throughout & No \\
\hline 567 & 1325 & 43.5 & 0.8 & 3.4 & 2.8 & At .5 (1/16 inch) fossil bed; small fossils throughout & No \\
\hline 568 & 1326 & 47.8 & 0.9 & 3 & 4.2 & $\begin{array}{l}\text { At } 6.5(1 / 8 \text { inch }) \text { mostly calcilutitic lamination; At } 9(1 / 4 \text { inch }) \text { bed with discontinuous bedding plane + } \\
\text { pyrite }\end{array}$ & No \\
\hline 569 & 1327 & 44.1 & 0.9 & 2.8 & 3.5 & $\begin{array}{l}\text { At } 2.25 \text { (1/4 inch) mostly calcisiltitic bed with discontinuous bedding plane; At } 4 \text { (1/4 inch) mostly } \\
\text { calcisiltitic bed with discontinuous bedding plane; At } 5.5 \text { (1/2 inch) alternating calcisiltite \& shale } \\
\text { lamination; At } 9.75 \text { ( } 1 / 4 \mathrm{inch}) \text { alternating calcisiltite \& shale lamination }\end{array}$ & No \\
\hline 570 & 1328 & 52.9 & 0.9 & 4.3 & 3.4 & $\begin{array}{l}\text { At } 2.75 \text { (1/4 inch) mostly calcilutitic lamination; At } 4.5 \text { trilobite; At } 8.25 \text { (1/8 inch) calcisiltite bed } \\
\text { calcilutite bed; At } 9 \text { alternating calcisiltite \& shale lamination; At } 10 \text { ( } 1 / 8 \text { inch) crinoid stem bed }\end{array}$ & Yes \\
\hline 571 & 1329 & 39.2 & 1 & 1.6 & 4.1 & $\begin{array}{l}\text { At } 3.25 \text { ( } 1 / 4 \text { inch) alternating calcisiltite \& shale; At } 10.5 \text { ( } 1 / 8 \text { inch) mostly shale, limited calcisiltite } \\
\text { bed with discontinuous bedding plane }\end{array}$ & No \\
\hline 572 & 1330 & 42 & 0.8 & 2.2 & 4.3 & At 4.5 (1.75 inch) calcilutite dominated carbonate bed; At 11.25 ( $<1 / 16$ inch calcilutitic lamina) & No \\
\hline 573 & 1331 & 48.1 & 0.8 & 3.9 & 2.8 & Dark; very few fossils; At 11.75 ( $<1 / 16$ inch calcilutitic lamina) & No \\
\hline 574 & 1332 & 42.5 & 1 & 2.4 & 3.6 & At 11 ( $<1 / 16$ inch calcilutitic lamina); Dark & No \\
\hline 575 & 1333 & 42.6 & 0.8 & 2.8 & 3.5 & Dark; very few small fossils & No \\
\hline 576 & 1334 & 46.8 & 0.9 & 3.1 & 3.8 & $\begin{array}{l}\text { At } 3 \text { ( }<1 / 16 \text { inch calcilutitic lamina) bed with discontinuous bedding plane; At } 3.5 \text { (1/4 inch) alternating } \\
\text { calcisiltite \& shale bed with discontinuous bedding plane; At } 5 \text { ( }<1 / 16 \text { inch calcilutitic lamina) bed with } \\
\text { discontinuous bedding plane; At } 7.5 \text { ( } 1 / 4 \text { inch) mostly calcisiltitic lamination }\end{array}$ & No \\
\hline 577 & 1335 & 44.6 & 0.8 & 3.5 & 3 & At 5.25 ( 1 inch) bentonite with ( $1 / 4$ inch) calcite vein & No \\
\hline 578 & 1336 & 42.4 & 0.7 & 2.8 & 3.9 & $\begin{array}{l}\text { At } 1.591 / 4 \text { inch) alternating calcisiltite \& shale bed with discontinuous bedding plane; At } 4 \text { (1/4 inch) } \\
\text { mostly calcilutitic; At } 6 \text { ( } 1 / 8 \text { inch) calcilutite bed; At } 11.5 \text { ( } 1 / 2 \text { inch) mostly shale, limited calcilutite } \\
\text { lamination }\end{array}$ & No \\
\hline 579 & 1337 & 47 & 0.7 & 3.5 & 3.9 & Dark; few (<1/16 inch calcilutitic lamina) & No \\
\hline
\end{tabular}









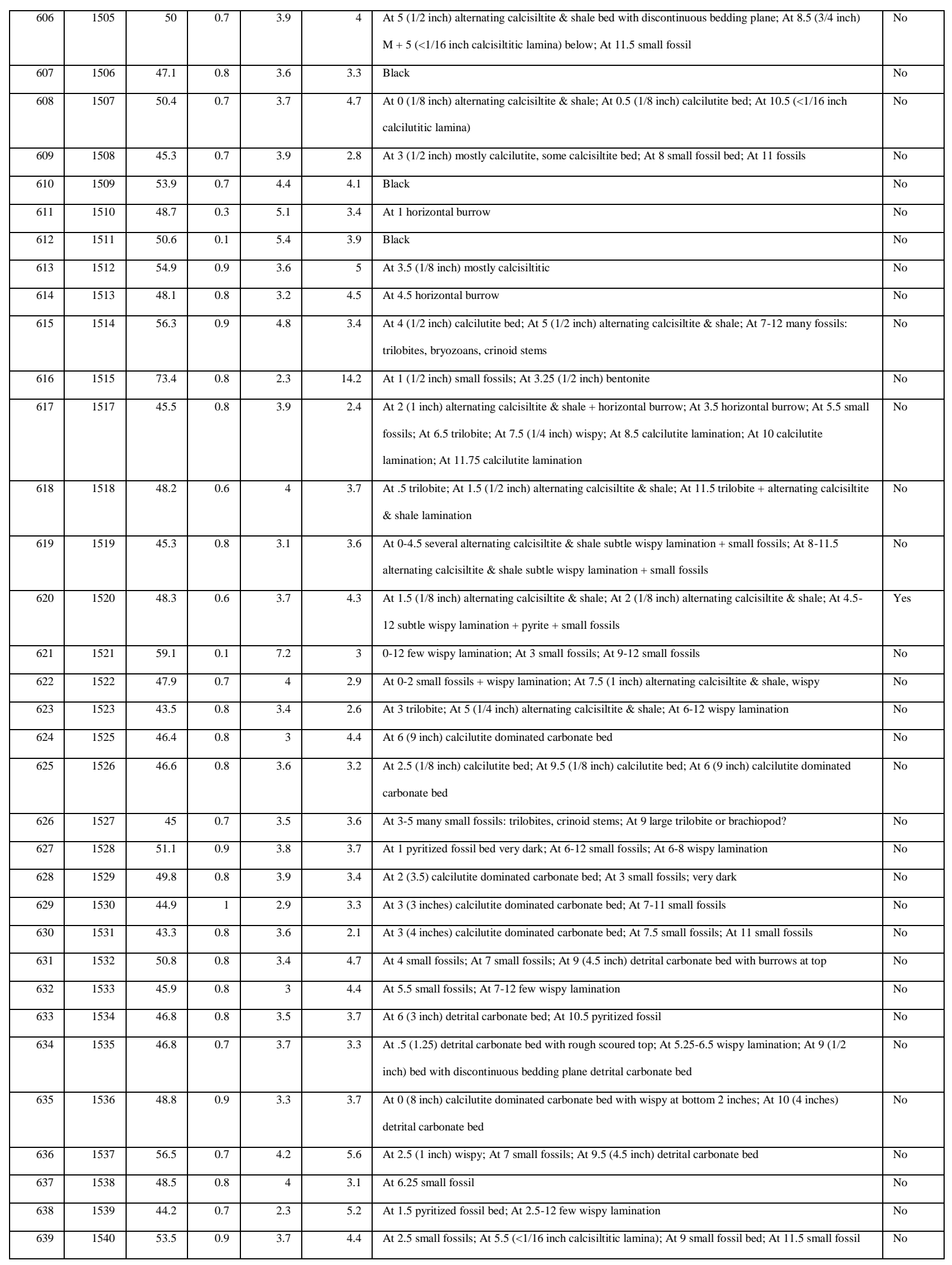




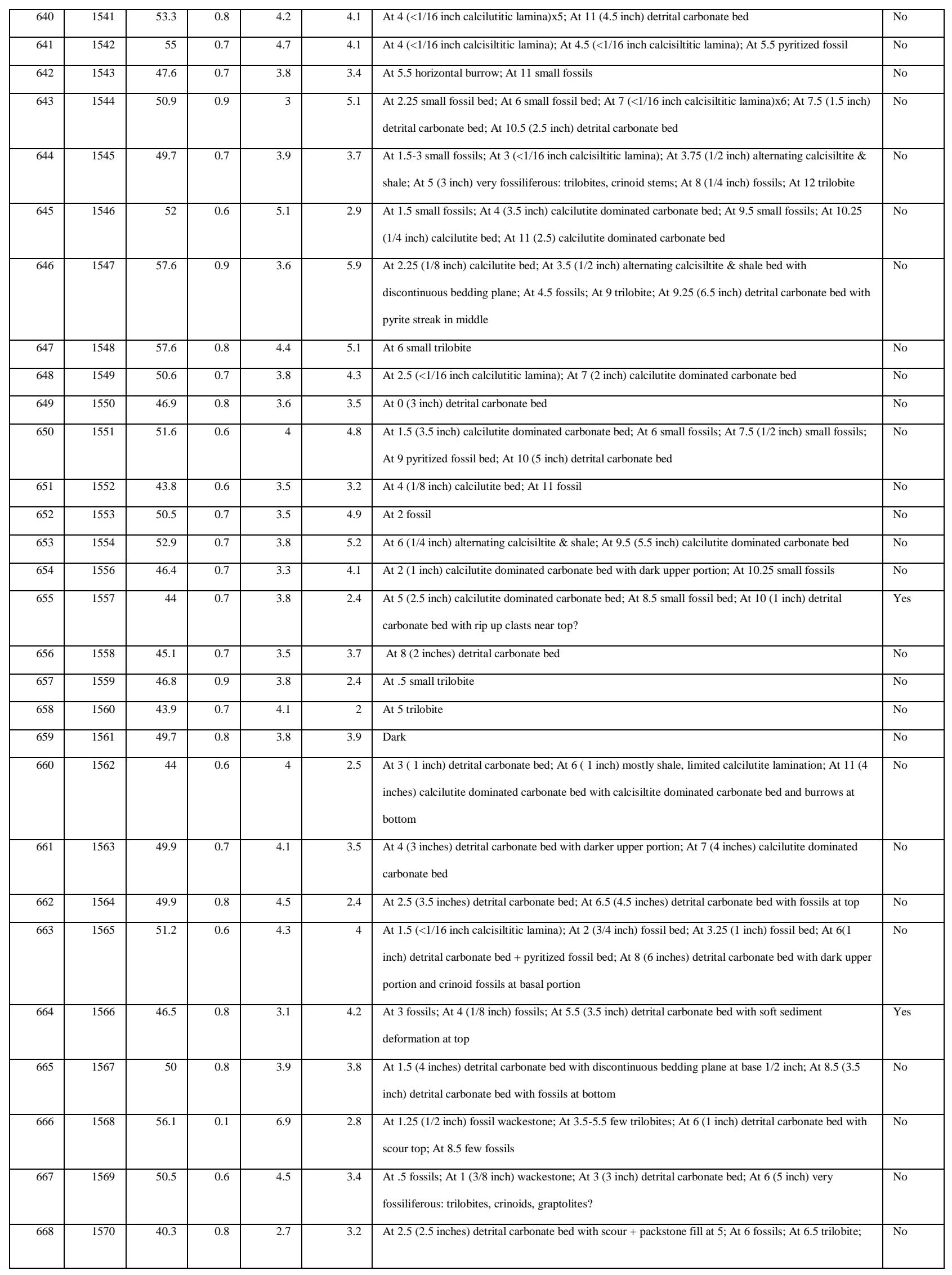




\begin{tabular}{|c|c|c|c|c|c|c|c|}
\hline & & & & & & At 7 fossils; At 9.5 ( 2 inch) detrital carbonate bed with rough top & \\
\hline 669 & 1571 & 49.4 & 0.7 & 4.2 & 3.4 & $\begin{array}{l}\text { At } 7 \text { (1/2 inch) few fossils; At } 3-4.5 \text { few fossils; At } 5.5 \text { ( } 3 / 4 \text { inch) trilobite wackestone; At } 6 \text { ( } 1 \text { inch) } \\
\text { detrital carbonate bed; At } 10.5 \text { small fossils; At } 11.5 \text { (1/2 inch) wackestone }\end{array}$ & No \\
\hline 670 & 1572 & 48.9 & 0.9 & 3.6 & 3.5 & $\begin{array}{l}\text { At } .75 \text { (3/4 inch) wackestone; At } 3.5 \text { small fossils; At } 6.5 \text { ( } 1 / 4 \text { inch) small fossils; At } 8.5 \text { ( } 1 \text { inch) mostly } \\
\text { shale, limited calcilutite planar lamination + fossils at bottom; At } 11 \text { small fossils; At } 11.5 \text { small fossils }\end{array}$ & No \\
\hline 671 & 1573 & 50 & 0.7 & 3.4 & 4.9 & At 2 (1/4 inch) mostly calcisiltitic + trilobite; At 4.5 trilobite; At 8.5 small fossil & No \\
\hline 672 & 1578 & 54.7 & 0.8 & 4.3 & 4.4 & $\begin{array}{l}\text { At } 0 \text { (1/2 inch) few fossils; At } 4 \text { few very small fossils; At } 5 \text { few very small fossils; At } 7 \text { few very small } \\
\text { fossils; At } 8 \text { ( } 3 / 4 \text { inch) pyrite specs }+ \text { small fossils at bottom; At } 9 \text { ( } 3 / 8 \text { inch) mostly shale, limited } \\
\text { calcisiltite bed with discontinuous bedding plane; At } 11.5 \text { ( } 1 \text { inch) detrital carbonate bed }\end{array}$ & No \\
\hline 673 & 1579 & 39.8 & 0.6 & 3.5 & 2.3 & At 1.5 small fossils; At 3 small fossils; At 3.5 small fossils & No \\
\hline 674 & 1581 & 46.2 & 0.6 & 4.1 & 2.7 & At 2 small fossils; At 8.5 small fossil & No \\
\hline 675 & 1582 & 47.7 & 0.8 & 3.7 & 3.6 & $\begin{array}{l}\text { At } 0.5 \text { very small fossils; At } 1.5 \text { ( } 1 / 8 \text { inch) alternating calcisiltite } \& \text { shale bed with discontinuous } \\
\text { bedding plane; At } 3 \text { ( } 1 / 2 \text { inch) alternating calcisiltite } \& \text { shale bed with discontinuous bedding plane + } \\
\text { horizontal burrow?; At } 7 \text { ( } 1 / 2 \text { inch) calcilutite bed with possible peloids or ooids }\end{array}$ & No \\
\hline 676 & 1583 & 47.8 & 0.7 & 3.9 & 3.3 & Bottom 8.5 inches missing & No \\
\hline 677 & 1584 & 49.1 & 0.7 & 4.7 & 2.3 & At 9 very small fossils & No \\
\hline 678 & 1585 & 56.7 & 0.7 & 4.6 & 4.7 & Very small fossils throughout; At 5.5 (1/4 inch) mostly shale, limited calcisiltite planar lamination & No \\
\hline 679 & 1586 & 49.9 & 0.8 & 4 & 3.2 & At 3 very small fossils; At 9 very small fossils & No \\
\hline 680 & 1587 & 51.2 & 0.7 & 3.8 & 4.8 & At $0-4$ few small fossils & No \\
\hline 681 & 1588 & 44.4 & 0.7 & 3 & 4.2 & At 1.5-3 few small fossils; at 5 trilobite; At 8.5 small fossils; At 10 few small fossils & No \\
\hline 682 & 1589 & 46.2 & 0.8 & 3.7 & 3 & At $1.5(<1 / 16$ inch calcisiltitic lamina $) \times 3$; At 4.5 trilobite $\times 2$; At 6 few small fossils & No \\
\hline 683 & 1590 & 46.9 & 0.8 & 3.4 & 3.5 & $\begin{array}{l}\text { At } 4 \text { (1/4 inch) alternating calcisiltite \& shale bed with discontinuous bedding plane; At } 4.25 \text { ( } 3.25 \\
\text { inch) calcilutite dominated carbonate bed; At } 11 \text { small fossils }\end{array}$ & No \\
\hline 684 & 1591 & 51.6 & 0.7 & 4.6 & 3.3 & At 1 fossil bed; At 2.5 small fossils; At $3.5-9$ missing; At 11 (1/4 inch) mostly shale, limited calcisiltite & No \\
\hline 685 & 1592 & 52 & 0.6 & 4.4 & 4.1 & $\begin{array}{l}\text { At } 3 \text { (1/2 inch) mostly shale, limited calcisiltite; At } 9 \text { (1/2 inch) detrital carbonate bed with rough base } \\
\text { and top; At } 10.75 \text { fossils; At } 11.5 \text { small fossils }\end{array}$ & No \\
\hline 686 & 1593 & 48.1 & 0.8 & 3.6 & 3.7 & $\begin{array}{l}\text { At } 1 \text { ( }<1 / 16 \text { inch calcisiltitic lamina)x2; At } 3 \text { fossils; At } 8.5 \text { Large brachiopod/bivalve?; At } 10.5 \text { Large } \\
\text { trilobite; At } 12 \text { large trilobite }\end{array}$ & No \\
\hline 687 & 1594 & 45.3 & 0.8 & 3.2 & 3.6 & Few small fossils throughout & No \\
\hline 688 & 1595 & 53.9 & 0.6 & 4.1 & 5.1 & $\begin{array}{l}\text { At } 2.25 \text { fossils; At } 6 \text { (1/2 inch) detrital carbonate bed; At } 8.5 \text { ( }<1 / 16 \text { inch calcisiltitic lamina); At } 11 \\
\text { trilobite }\end{array}$ & No \\
\hline 689 & 1596 & 47 & 0.8 & 3.5 & 3.4 & At 3 (1/4 inch) wackestone; At 6-12 few small fossils & No \\
\hline 690 & 1597 & 47.8 & 0.7 & 3.5 & 4.2 & At 4.5 (1/16 inch) calcisiltite bed few small fossils throughout & No \\
\hline 691 & 1598 & 45.6 & 0.6 & 3.4 & 4 & $\begin{array}{l}\text { At } 3.75 \text { (1/2 inch) alternating calcisiltite \& shale scour top; At } 9 \text { (1/2 inch) mostly shale, limited } \\
\text { calcilutite bed with discontinuous bedding plane with horizontal burrow?; small fossils throughout }\end{array}$ & No \\
\hline 692 & 1599 & 54.2 & 0.7 & 3.7 & 5.4 & Very few very small fossils & No \\
\hline 693 & 1600 & 56.9 & 0.6 & 4.9 & 4.8 & At 0 brachiopodsx 3 ; At 4.5 small fossils; At 5 ( $3 / 4$ inch) bentonite & No \\
\hline 694 & 1601 & 47.7 & 0.7 & 3.1 & 4.7 & At 7-9 few fossils & No \\
\hline 695 & 1602 & 52 & 0.7 & 4.4 & 3.8 & few fossils throughout & No \\
\hline 696 & 1603 & 49.6 & 0.7 & 3.4 & 4.7 & At 2.5 (1.5) wackestone + pyrite specs & No \\
\hline 697 & 1604 & 42.3 & 0.7 & 3.3 & 2.9 & Small fossils throughout & No \\
\hline 698 & 1605 & 48.3 & 0.7 & 3.7 & 3.8 & First 3.5 inches missing; At 5 ( 1 inch) few fossils + horizontal burrow?; At 8-10 few fossils & No \\
\hline 699 & 1606 & 47.6 & 0.9 & 3.2 & 3.6 & At 2 pyritized fossil bed lamina + few small fossils; At 11 very small fossils & No \\
\hline 700 & 1607 & 52.6 & 0.8 & 3.8 & 4.5 & At 1.5 small pyritized fossil & No \\
\hline
\end{tabular}









\begin{tabular}{|c|c|c|c|c|c|c|c|}
\hline 736 & 1647 & 47.2 & 0.8 & 3.2 & 4.2 & At 6 small fossil bed; At 11 (1/4 inch) calcilutite & No \\
\hline 737 & 1649 & 43 & 0.6 & 3.9 & 2.3 & Few dark lamination; few very small fossils & No \\
\hline 738 & 1650 & 48.3 & 0.7 & 3.9 & 3.4 & At 1 ( $1 / 8$ inch) fossils; At 4.5 ( $1 / 8$ inch) fossils + pyrite; At 8 ( 10 inches) alternating calcisiltite $\&$ shale & No \\
\hline 739 & 1651 & 52.2 & 0.7 & 4 & 4.6 & Dark & No \\
\hline 740 & 1653 & 45.8 & 0.7 & 3.9 & 2.6 & $\begin{array}{l}\text { At } 1(<1 / 16 \text { inch calcisiltitic lamina); At } 5 \text { (1/4 inch) calcilutite bed; At } 9(1 / 2 \text { inch) calcilutite bed } x 2 \text {; } \\
\text { At } 11 \text { (1/2 inch) mostly calcilutitic lamination }\end{array}$ & No \\
\hline 741 & 1654 & 47.4 & 0.5 & 4.1 & 3.7 & $\begin{array}{l}\text { At } 0.5 \text { ( } 1 / 4 \text { inch) mostly calcilutitic; At } 1.5 \text { (1/4 inch) alternating calcisiltite \& shale; At } 3.5 \text { (1/4 inch) } \\
\text { alternating calcisiltite \& shale; At } 6.25 \text { ( } 1 / 4 \text { inch) calcilutite bed; At } 8 \text { (1/4 inch) calcilutite bed; At } 9.5 \\
\text { (1/8 inch) calcilutite bed; At } 11 \text { ( } 1 / 8 \text { inch) calcilutite }\end{array}$ & No \\
\hline 742 & 1655 & 42.3 & 0.7 & 3.6 & 2.5 & At 0 small fossil bed; At 4.5 (1/8 inch) small fossils; small fossils throughout & No \\
\hline 743 & 1656 & 42.9 & 0.6 & 3.6 & 3.1 & missing & No \\
\hline 744 & 1657 & 40.1 & 0.7 & 3.3 & 2.5 & $0-9$ missing; 9-12 dark & No \\
\hline 745 & 1658 & 42.6 & 0.6 & 3.6 & 2.7 & $0-7.5$ missing; $9-12$ very fossiliferous & No \\
\hline 746 & 1659 & 40.6 & 0.8 & 2.8 & 2.9 & Trenton Black River & Yes \\
\hline
\end{tabular}

\subsection{Appendix B}

Flat Creek joints.

\begin{tabular}{|c|c|c|c|c|c|c|c|}
\hline \multicolumn{2}{|c|}{ Lower Section 1} & \multicolumn{2}{|c|}{ Lower Section 2} & \multicolumn{2}{|l|}{ Mid Section } & \multicolumn{2}{|c|}{ Upper Section } \\
\hline $\begin{array}{l}\text { Scan Line } \\
\text { Location }\end{array}$ & $\begin{array}{l}\text { Strike } \\
\text { Azimuth }\end{array}$ & $\begin{array}{l}\text { Scan Line } \\
\text { Location }\end{array}$ & $\begin{array}{l}\text { Strike } \\
\text { Azimuth }\end{array}$ & $\begin{array}{l}\text { Scan Line } \\
\text { Location }\end{array}$ & $\begin{array}{l}\text { Strike } \\
\text { Azimuth }\end{array}$ & $\begin{array}{l}\text { Scan Line } \\
\text { Location }\end{array}$ & $\begin{array}{l}\text { Strike } \\
\text { Azimuth }\end{array}$ \\
\hline 0.2 & 280 & 23.1 & 280 & 39.93 & 190 & 6.2 & 120 \\
\hline 0.9 & 280 & 23.3 & 280 & 43.41 & 110 & 7 & 160 \\
\hline 1.2 & 280 & 23.4 & 280 & 44.25 & 110 & 8.5 & 155 \\
\hline 1.5 & 280 & 25.12 & 280 & 45.94 & 265 & 12.06 & 280 \\
\hline 1.7 & 280 & 25.18 & 275 & 46.03 & 260 & 12.64 & 115 \\
\hline 2.8 & 280 & 25.34 & 275 & 46.19 & 260 & 12.99 & 285 \\
\hline 3 & 310 & 26.61 & 280 & 46.54 & 265 & 14.45 & 105 \\
\hline 3.18 & 310 & 26.63 & 280 & 46.72 & 265 & 20.08 & 112 \\
\hline 5.85 & 280 & 28.5 & 280 & 46.73 & 265 & 20.13 & 112 \\
\hline 5.92 & 280 & 28.55 & 280 & 49.3 & 265 & 20.27 & 112 \\
\hline 5.94 & 280 & 28.72 & 275 & 49.37 & 130 & 21.42 & 280 \\
\hline 5.95 & 280 & 29.01 & 282 & 49.66 & 270 & 21.52 & 280 \\
\hline 6 & 280 & 29.14 & 100 & 49.68 & 125 & 27.8 & 145 \\
\hline 6.3 & 280 & 29.95 & 100 & 50.05 & 130 & 28.65 & 305 \\
\hline 7.64 & 280 & 30.05 & 280 & 50.09 & 270 & 29.3 & 110 \\
\hline 8.19 & 280 & 30.51 & 283 & 50.45 & 270 & 30.9 & 105 \\
\hline 8.26 & 280 & 30.72 & 280 & 50.47 & 270 & 31.03 & 110 \\
\hline 8.34 & 280 & 31.05 & 100 & 50.5 & 270 & 31.36 & 100 \\
\hline
\end{tabular}




\begin{tabular}{|c|c|c|c|c|c|c|c|}
\hline 8.47 & 280 & 31.26 & 100 & 50.6 & 115 & 31.94 & 290 \\
\hline 8.7 & 280 & 32.75 & 95 & 50.7 & 270 & 32.04 & 290 \\
\hline 8.71 & 280 & 33.81 & 280 & 51.43 & 270 & 32.2 & 110 \\
\hline 9.4 & 275 & 34.01 & 280 & 51.81 & 270 & 32.37 & 345 \\
\hline 9.6 & 275 & 34.1 & 280 & 52.4 & 270 & 34.8 & 330 \\
\hline 9.7 & 275 & 34.3 & 280 & 52.71 & 270 & 35.26 & 110 \\
\hline 29.17 & 280 & 34.36 & 280 & 52.98 & 270 & 36.1 & 164 \\
\hline 30.55 & 280 & 34.47 & 280 & 53.08 & 270 & 41.1 & 280 \\
\hline 34.58 & 280 & 34.55 & 280 & 53.15 & 270 & 41.62 & 101 \\
\hline 45.5 & 280 & 34.58 & 96 & 53.46 & 270 & 41.82 & 280 \\
\hline & & 34.93 & 280 & 53.5 & 270 & 46.45 & 296 \\
\hline & & 35.07 & 280 & 53.8 & 270 & 46.46 & 296 \\
\hline & & 35.41 & 280 & 53.86 & 270 & 46.97 & 288 \\
\hline & & 35.45 & 280 & 54.98 & 270 & 47.17 & 295 \\
\hline & & 35.67 & 285 & 56.9 & 270 & 51.92 & 275 \\
\hline & & 36.01 & 290 & 57.57 & 125 & 51.74 & 275 \\
\hline & & 36.2 & 295 & 57.62 & 115 & 51.98 & 270 \\
\hline & & 36.32 & 300 & 57.98 & 120 & 52.01 & 105 \\
\hline & & 36.49 & 305 & 58.02 & 120 & & \\
\hline & & 36.3 & 285 & 58.65 & 270 & & \\
\hline & & 37.14 & 285 & 59.02 & 130 & & \\
\hline & & & & 59.2 & 270 & & \\
\hline & & & & 59.27 & 270 & & \\
\hline
\end{tabular}

Canajoharie Creek scan lines:

\begin{tabular}{|c|c|c|c|c|c|c|c|}
\hline \multicolumn{2}{|l|}{ Scan Line 1} & \multicolumn{2}{|l|}{ Scan Line 2} & \multicolumn{2}{|l|}{ Scan Line 3} & \multicolumn{2}{|l|}{ Scan Line 4} \\
\hline $\begin{array}{l}\text { Scan Line } \\
\text { Location }\end{array}$ & $\begin{array}{l}\text { Strike } \\
\text { Azimuth }\end{array}$ & $\begin{array}{l}\text { Scan Line } \\
\text { Location }\end{array}$ & $\begin{array}{l}\text { Strike } \\
\text { Azimuth }\end{array}$ & $\begin{array}{l}\text { Scan Line } \\
\text { Location }\end{array}$ & $\begin{array}{l}\text { Strike } \\
\text { Azimuth }\end{array}$ & $\begin{array}{l}\text { Scan Line } \\
\text { Location }\end{array}$ & $\begin{array}{l}\text { Strike } \\
\text { Azimuth }\end{array}$ \\
\hline 0.00 & 271 & 0.00 & 276 & 0.00 & 260 & 0.00 & 280 \\
\hline 0.94 & 275 & 0.66 & 277 & 0.30 & 280 & 0.30 & 245 \\
\hline 1.68 & 216 & 1.52 & 275 & 1.52 & 254 & 0.36 & 243 \\
\hline 3.12 & 284 & 2.08 & 278 & 1.55 & 242 & 1.40 & 242 \\
\hline 3.23 & 240 & 2.69 & 274 & 1.60 & 246 & 1.55 & 244 \\
\hline 3.86 & 278 & 3.43 & 278 & 1.63 & 242 & 1.78 & 243 \\
\hline 4.14 & 278 & 3.61 & 275 & 2.82 & 281 & 2.13 & 282 \\
\hline 4.45 & 279 & 3.84 & 276 & 4.80 & 271 & 3.43 & 279 \\
\hline
\end{tabular}




\begin{tabular}{|c|c|c|c|c|c|c|c|}
\hline 4.50 & 277 & 4.09 & 274 & 5.38 & 272 & 3.61 & 279 \\
\hline 5.08 & 280 & 4.39 & 276 & 6.05 & 278 & 4.80 & 244 \\
\hline 5.26 & 270 & 5.38 & 276 & 6.40 & 276 & 5.21 & 278 \\
\hline 5.33 & 280 & & & 7.11 & 281 & 5.87 & 272 \\
\hline 5.44 & 279 & & & 7.52 & 215 & 6.20 & 277 \\
\hline 5.56 & 275 & & & 8.41 & 278 & 6.60 & 271 \\
\hline 5.92 & 270 & & & 9.14 & 275 & 6.65 & 280 \\
\hline 6.05 & 280 & & & 9.75 & 215 & 6.68 & 275 \\
\hline 6.22 & 275 & & & 10.92 & 275 & 7.01 & 255 \\
\hline 6.30 & 280 & & & 11.10 & 223 & 7.16 & 265 \\
\hline 6.40 & 260 & & & 11.30 & 224 & 7.29 & 243 \\
\hline 6.78 & 246 & & & 11.68 & 243 & 7.44 & 277 \\
\hline 7.21 & 280 & & & 12.42 & 278 & 7.70 & 277 \\
\hline 7.49 & 230 & & & & & 7.95 & 276 \\
\hline 7.90 & 281 & & & & & 8.26 & 280 \\
\hline 8.48 & 280 & & & & & 8.59 & 275 \\
\hline 8.81 & 281 & & & & & 8.76 & 280 \\
\hline 8.81 & 282 & & & & & 8.92 & 275 \\
\hline 9.68 & 281 & & & & & 9.04 & 255 \\
\hline 9.91 & 280 & & & & & 9.19 & 285 \\
\hline 10.39 & 281 & & & & & 9.45 & 277 \\
\hline 10.90 & 279 & & & & & 9.55 & 226 \\
\hline 10.97 & 280 & & & & & 9.86 & 265 \\
\hline 11.28 & 280 & & & & & 9.93 & 263 \\
\hline 11.71 & 280 & & & & & 10.57 & 357 \\
\hline 12.80 & 280 & & & & & 11.02 & 285 \\
\hline 13.00 & 275 & & & & & 11.79 & 285 \\
\hline 14.35 & 280 & & & & & 12.14 & 281 \\
\hline 14.94 & 281 & & & & & & \\
\hline 15.27 & 259 & & & & & & \\
\hline 15.34 & 259 & & & & & & \\
\hline 15.80 & 240 & & & & & & \\
\hline
\end{tabular}

\begin{tabular}{|c|c|c|c|c|c|c|c|c|c|}
\hline \multicolumn{2}{|c|}{ Scan Line 5} & \multicolumn{2}{|c|}{ Scan Line 6} & \multicolumn{2}{|c|}{ Scan Line 7} & \multicolumn{2}{|c|}{ Scan Line 8} & \multicolumn{2}{|c|}{ Scan Line 9} \\
\hline Scan Line & Strike & Scan Line & Strike & Scan Line & Strike & Scan Line & Strike & Scan Line & Strike \\
\hline Location & Azimuth & Location & Azimuth & Location & Azimuth & Location & Azimuth & Location & Azimuth \\
\hline 0.30 & 280 & 0.25 & 278 & 1.02 & 280 & 0.38 & 249 & 1.19 & 285 \\
\hline 0.53 & 274 & 1.09 & 250 & 1.70 & 277 & 0.76 & 294 & 1.52 & 280 \\
\hline 0.74 & 273 & 1.12 & 274 & 1.75 & 280 & 1.04 & 285 & 2.69 & 305 \\
\hline
\end{tabular}




\begin{tabular}{|c|c|c|c|c|c|c|c|c|c|}
\hline 0.86 & 285 & 1.60 & 275 & 1.96 & 280 & 1.27 & 268 & 3.25 & 275 \\
\hline 1.22 & 275 & 2.06 & 277 & 2.31 & 275 & 1.60 & 265 & 3.73 & 285 \\
\hline 1.65 & 275 & 2.57 & 274 & 2.51 & 280 & 2.08 & 280 & 5.18 & 260 \\
\hline 1.57 & 278 & 3.02 & 275 & 2.62 & 279 & 2.67 & 285 & 5.97 & 305 \\
\hline & & 3.61 & 265 & 2.64 & 278 & 3.81 & 260 & 6.35 & 243 \\
\hline & & 3.73 & 280 & 2.72 & 285 & 9.14 & 260 & 7.62 & 245 \\
\hline & & 3.76 & 280 & 3.00 & 275 & 9.40 & 280 & 8.61 & 250 \\
\hline & & 4.47 & 284 & 3.38 & 275 & 9.91 & 262 & 9.14 & 280 \\
\hline & & 4.88 & 273 & 3.48 & 285 & 9.30 & 255 & 11.07 & 245 \\
\hline & & 5.36 & 279 & 3.78 & 285 & 10.67 & 250 & 12.07 & 250 \\
\hline & & 5.99 & 277 & 3.96 & 250 & 10.85 & 255 & & \\
\hline & & 6.27 & 285 & 4.17 & 275 & 11.71 & 305 & & \\
\hline & & 6.68 & 276 & 4.19 & 281 & 12.52 & 307 & & \\
\hline & & 7.80 & 280 & 4.45 & 273 & 13.49 & 308 & & \\
\hline & & 9.12 & 262 & 4.88 & 270 & 14.78 & 309 & & \\
\hline & & 9.45 & 270 & 5.41 & 285 & 15.70 & 255 & & \\
\hline & & & & 5.49 & 276 & 16.64 & 235 & & \\
\hline & & & & 5.89 & 275 & & & & \\
\hline & & & & 6.65 & 280 & & & & \\
\hline & & & & 6.73 & 251 & & & & \\
\hline & & & & 6.81 & 280 & & & & \\
\hline & & & & 7.14 & 280 & & & & \\
\hline & & & & 7.47 & 260 & & & & \\
\hline & & & & 7.65 & 280 & & & & \\
\hline & & & & 8.23 & 275 & & & & \\
\hline & & & & 8.89 & 273 & & & & \\
\hline & & & & 9.25 & 285 & & & & \\
\hline & & & & 10.24 & 255 & & & & \\
\hline & & & & 10.34 & 285 & & & & \\
\hline & & & & 10.80 & 255 & & & & \\
\hline & & & & 12.24 & 265 & & & & \\
\hline & & & & 12.34 & 285 & & & & \\
\hline & & & & 12.37 & 285 & & & & \\
\hline
\end{tabular}




\subsection{Appendix C}

Bentonite termination data is shaded in red.

\begin{tabular}{|c|c|c|c|c|c|}
\hline \multicolumn{2}{|l|}{ Lower Section } & \multicolumn{2}{|l|}{ Mid Section } & \multicolumn{2}{|l|}{ Upper Section } \\
\hline Upper Termination & Count & Upper Termination & Count & Upper Termination & Count \\
\hline 0.85 & 1 & 0 & 3 & 0.4 & 6 \\
\hline 1.1 & 1 & 0.1 & 1 & 0.9 & 4 \\
\hline 1.4 & 4 & 0.2 & 2 & 1 & 1 \\
\hline 1.5 & 2 & 0.21 & 1 & 1.3 & 3 \\
\hline 1.6 & 1 & 0.22 & 1 & 1.7 & 2 \\
\hline 1.7 & 1 & 0.3 & 2 & 1.8 & 1 \\
\hline 1.8 & 14 & 0.4 & 8 & 2 & 2 \\
\hline 2.2 & 1 & 0.45 & 1 & 2.1 & 9 \\
\hline$?$ & 13 & 0.7 & 1 & Lower Termination & Count \\
\hline Lower Termination & Count & 1.2 & 7 & 0.4 & 2 \\
\hline 0.3 & 6 & $?$ & 13 & 0.8 & 1 \\
\hline 0.75 & 2 & Lower Termination & Count & 0.9 & 5 \\
\hline 0.8 & 1 & 0 & 13 & 1.6 & 1 \\
\hline 0.9 & 1 & 0.18 & 2 & $?$ & 27 \\
\hline 1 & 5 & 0.2 & 1 & & \\
\hline 1.1 & 2 & 0.3 & 2 & & \\
\hline 1.2 & 3 & $?$ & 23 & & \\
\hline 1.5 & 1 & & & & \\
\hline 1.7 & 1 & & & & \\
\hline 1.8 & 1 & & & & \\
\hline$?$ & 12 & & & & \\
\hline
\end{tabular}

\subsection{Appendix D}

\begin{tabular}{|c|c|c|c|c|c|}
\hline \multicolumn{6}{|c|}{ Lower Section } \\
\hline Vert. $\mathrm{m}$ & Terminate Aptr. & Vert. $\mathrm{m}$ & Step-Over Aptr. & Vert. $\mathrm{m}$ & Cross-Cut Aptr. \\
\hline 1.8 & $<.1$ & 1.8 & 3 & 1.8 & $<.1$ \\
\hline 1.8 & $<.1$ & 2.7 & 3 & 1.8 & 4 \\
\hline 1.8 & 2 & & & 0.3 & 4 \\
\hline 1.8 & $<.1$ & & & 0.3 & 3 \\
\hline 1.8 & $<.1$ & & & 0.3 & $<.1$ \\
\hline
\end{tabular}




\begin{tabular}{|c|c|c|c|c|c|}
\hline 1.8 & $<.1$ & & & 0.3 & 2 \\
\hline 1.8 & $<.1$ & & & & \\
\hline 1.8 & $<.1$ & & & & \\
\hline 1.8 & $<.1$ & & & & \\
\hline 1.8 & $<.1$ & & & & \\
\hline 1.8 & $<.1$ & & & & \\
\hline 1.8 & $<.1$ & & & & \\
\hline 1.8 & $<.1$ & & & & \\
\hline 0.3 & $<.1$ & & & & \\
\hline 0.3 & $<.1$ & & & & \\
\hline 0.3 & $<.1$ & & & & \\
\hline 0.3 & $<.1$ & & & & \\
\hline 0.3 & 2 & & & & \\
\hline 0.3 & 4 & & & & \\
\hline 1.8 & $<.1$ & & & & \\
\hline \multicolumn{6}{|l|}{ Mid Section } \\
\hline Vert. $\mathrm{m}$ & Terminate Aptr. & Vert. $\mathrm{m}$ & Step-Over Aptr. & Vert. $\mathrm{m}$ & Cross-Cut Aptr. \\
\hline 0 & 1 & 0 & 3 & 1.2 & $\begin{array}{l}<.1 \\
\end{array}$ \\
\hline 0 & 5 & 1.2 & 3 & 0 & 16 \\
\hline 1.2 & $<.1$ & 1.2 & 16 & 0 & $<.1$ \\
\hline 1.2 & 0.5 & 1.2 & 7 & 0 & 0.05 \\
\hline 0 & $<.1$ & 0 & $<.1$ & & \\
\hline 0 & $<.1$ & 0 & 8 & & \\
\hline 0 & $<.1$ & & & & \\
\hline 0 & $<.1$ & & & & \\
\hline 0 & $<.1$ & & & & \\
\hline 0 & $<.1$ & & & & \\
\hline 0 & $<.1$ & & & & \\
\hline 0 & $<.1$ & & & & \\
\hline 0 & $<.1$ & & & & \\
\hline 0 & $<.1$ & & & & \\
\hline 0 & $<.1$ & & & & \\
\hline 0 & $<.1$ & & & & \\
\hline 0 & 7 & & & & \\
\hline \multicolumn{6}{|c|}{ Upper Section } \\
\hline Vert. $\mathrm{m}$ & Terminate Aptr. & Vert. $\mathrm{m}$ & Step-Over Aptr. & Vert. $\mathrm{m}$ & Cross-Cut Aptr. \\
\hline 0.4 & $<.1$ & 0.4 & 1 & 0.4 & $<.1$ \\
\hline 0.4 & $<.1$ & 0.9 & $<.1$ & 0.9 & $<.1$ \\
\hline 0.4 & $<.1$ & 0.4 & $<.1$ & 0.9 & $<.1$ \\
\hline 0.4 & $<.1$ & 0.9 & $<.1$ & 0.9 & $<.1$ \\
\hline
\end{tabular}




\begin{tabular}{|c|c|c|c|c|c|}
\hline 0.4 & $<.1$ & 0.4 & $<.1$ & 0.9 & $<.1$ \\
\hline 0.4 & $<.1$ & 0.9 & $<.1$ & 0.9 & $<.1$ \\
\hline 0.9 & $<.1$ & 0.4 & $<.1$ & 0.9 & $<.1$ \\
\hline 0.9 & $<.1$ & 0.9 & $<.1$ & 0.9 & 1 \\
\hline 0.9 & $<.1$ & & & & \\
\hline 2.1 & $<.1$ & & & & \\
\hline 2.1 & $<.1$ & & & & \\
\hline 2.1 & $<.1$ & & & & \\
\hline 2.1 & $<.1$ & & & & \\
\hline 2.1 & $<.1$ & & & & \\
\hline 2.1 & $<.1$ & & & & \\
\hline 2.1 & $<.1$ & & & & \\
\hline 2.1 & $<.1$ & & & & \\
\hline 2.1 & $<.1$ & & & & \\
\hline 0.4 & $<.1$ & & & & \\
\hline 0.9 & $<.1$ & & & & \\
\hline 0.9 & $<.1$ & & & & \\
\hline 0.9 & $<.1$ & & & & \\
\hline 0.9 & $<.1$ & & & & \\
\hline
\end{tabular}

\subsection{Appendix E}

$\mathrm{X}$ denotes the bentonites that could not be measured.

\begin{tabular}{|c|c|c|c|}
\hline Lower FC Vertical Interval (m) & Schmidt ID & Q-Value & S-Value \\
\hline 0.1 & 0605 & 54 & 3.3 \\
\hline 0.3 & $\mathrm{X}$ & $\mathrm{X}$ & $\bar{x}$ \\
\hline 0.4 & 0615 & 59.6 & 4.4 \\
\hline 0.6 & 0626 & 74.2 & 1.8 \\
\hline 0.8 & 0636 & 72.5 & 3.1 \\
\hline 1.0 & 0646 & 47.9 & 1.4 \\
\hline 1.0 & 0656 & 60.4 & 2.5 \\
\hline 1.0 & 0666 & 76.2 & 1.7 \\
\hline 1.2 & 0676 & 72.5 & 1.7 \\
\hline 1.4 & 0686 & 73.2 & 3 \\
\hline 1.6 & 0696 & 71.8 & 2.9 \\
\hline 1.8 & 0706 & 14.8 & 2.8 \\
\hline 2.0 & 0716 & 70.8 & 2.3 \\
\hline 2.2 & 0726 & 76.7 & 1.3 \\
\hline 2.4 & 0736 & 68.1 & 3.6 \\
\hline 2.6 & 0746 & 69.1 & 2.4 \\
\hline
\end{tabular}




\begin{tabular}{|c|c|c|c|}
\hline 2.7 & $\mathrm{X}$ & $\mathrm{X}$ & $\mathrm{X}$ \\
\hline 2.8 & 0756 & 63.2 & 3.6 \\
\hline Mid FC Vertical Interval (m) & Schmidt ID & Q-Value & S-Value \\
\hline-0.1 & 0766 & 60.8 & 1.8 \\
\hline 0.0 & $\mathrm{X}$ & $\mathrm{X}$ & $\mathrm{X}$ \\
\hline 0.2 & 0776 & 56.9 & 3.7 \\
\hline 0.4 & 0807 & 61.9 & 2.8 \\
\hline 0.6 & 0797 & 64.3 & 2.6 \\
\hline 0.8 & 0817 & 70.4 & 2.9 \\
\hline 1.0 & 0827 & 61.1 & 1.8 \\
\hline 1.2 & 0837 & 19.0 & 4.1 \\
\hline 1.4 & 0847 & 59.9 & 3.4 \\
\hline 1.5 & 0857 & 70.4 & 3.0 \\
\hline Upper FC Vertical Interval (m) & Schmidt ID & Q-Value & S-Value \\
\hline 0.2 & 0867 & 54.0 & 4.4 \\
\hline 0.4 & 0877 & 35.4 & 3.4 \\
\hline 0.6 & 0899 & 65.3 & 3.5 \\
\hline 0.8 & 0919 & 41.7 & 1.3 \\
\hline 0.9 & 0929 & 15.0 & 3.2 \\
\hline 1.2 & 0939 & 66.4 & 2.3 \\
\hline 1.4 & 0949 & 72.4 & 1.2 \\
\hline 1.6 & 0959 & 68.7 & 3.2 \\
\hline 1.8 & 0969 & 64.8 & 3.2 \\
\hline 2.1 & 0979 & 14.8 & 1.4 \\
\hline Dolgeville Vertical Interval $(\mathrm{cm})$ & Schmidt ID & Q-Value & S-Value \\
\hline 5.0 & 1011 & 65.3 & 0.3 \\
\hline 9.5 & 1022 & 57.6 & 0.6 \\
\hline 11.5 & 1032 & 23.1 & 1.6 \\
\hline 14.0 & 1042 & 52.7 & 1.8 \\
\hline 21.0 & 1052 & 61.2 & 2.6 \\
\hline 29.0 & 1062 & 71.1 & 1.0 \\
\hline 40.5 & 1072 & 68.4 & 1.6 \\
\hline 46.5 & 1082 & 67.3 & 1.5 \\
\hline 50.3 & 1092 & 58.8 & 4.0 \\
\hline 55.0 & 1102 & 47.5 & 0.9 \\
\hline 60.5 & 1112 & 48.7 & 1.1 \\
\hline
\end{tabular}




\subsection{Appendix F}

Estimated bentonite rock strength values are shaded in red.

\begin{tabular}{|c|c|c|c|c|c|}
\hline Rock Strength & Interval & Step-Overs & Terminations & Both T \& S-O & Interval \\
\hline \multicolumn{2}{|l|}{ Lower } & \multicolumn{4}{|c|}{ Lower } \\
\hline 54 & 0.1 & 0 & 6 & 6 & 0.30 \\
\hline 19.8 & 0.3 & 1 & 0 & 1 & 0.70 \\
\hline 59.6 & 0.4 & 0 & 2 & 2 & 0.75 \\
\hline 74.2 & 0.6 & 0 & 1 & 1 & 0.80 \\
\hline 72.5 & 0.8 & 0 & 1 & 1 & 0.85 \\
\hline 76.2 & 1.0 & 1 & 1 & 2 & 0.90 \\
\hline 72.5 & 1.2 & 1 & 5 & 6 & 1.00 \\
\hline 73.2 & 1.4 & 0 & 3 & 3 & 1.10 \\
\hline 14.8 & 1.8 & 0 & 8 & 8 & 1.40 \\
\hline 70.8 & 2.0 & 0 & 3 & 3 & 1.50 \\
\hline 76.7 & 2.2 & 0 & 1 & 1 & 1.60 \\
\hline 68.1 & 2.4 & 0 & 2 & 2 & 1.70 \\
\hline 69.1 & 2.6 & 2 & 15 & 17 & 1.80 \\
\hline 19.8 & 2.7 & 0 & 1 & 1 & 2.20 \\
\hline 63.2 & 2.8 & 0 & 1 & 1 & 2.30 \\
\hline \multicolumn{2}{|l|}{ Mid } & 1 & 0 & 1 & 2.70 \\
\hline 60.8 & 3.7 & \multicolumn{4}{|c|}{ Mid } \\
\hline 56.9 & 4 & 0 & 1 & 1 & 3.90 \\
\hline 61.9 & 4.2 & 0 & 2 & 2 & 3.98 \\
\hline 64.3 & 4.4 & 0 & 3 & 3 & 4.00 \\
\hline 70.4 & 4.6 & 0 & 1 & 1 & 4.01 \\
\hline 61.1 & 4.8 & 0 & 1 & 1 & 4.02 \\
\hline 19 & 5 & 0 & 4 & 4 & 4.10 \\
\hline 59.9 & 5.2 & 0 & 8 & 8 & 4.20 \\
\hline 70.4 & 5.3 & 0 & 1 & 1 & 4.25 \\
\hline \multicolumn{2}{|l|}{ Upper } & 0 & 1 & 1 & 4.30 \\
\hline 54 & 5.5 & 0 & 1 & 1 & 4.50 \\
\hline 35.4 & 5.7 & 3 & 7 & 10 & 5.00 \\
\hline 65.3 & 5.9 & \multicolumn{4}{|c|}{ Upper } \\
\hline 41.7 & 6.1 & 4 & 8 & 12 & 5.70 \\
\hline 15 & 6.2 & 0 & 1 & 1 & 6.10 \\
\hline 66.4 & 6.5 & 4 & 9 & 13 & 6.20 \\
\hline 72.4 & 6.7 & 0 & 1 & 1 & 6.30 \\
\hline
\end{tabular}




\begin{tabular}{|r|r|r|r|r|r|}
\hline 68.7 & 6.9 & 0 & 3 & 3 & 6.60 \\
\hline 64.8 & 7.1 & 0 & 1 & 1 & 6.90 \\
\hline 14.8 & 7.4 & 0 & 2 & 2 & 7.00 \\
\hline & & 0 & 1 & 1 & 7.10 \\
\hline & & 0 & 2 & 2 & 7.30 \\
\hline & & 0 & 9 & 9 & 7.40 \\
\hline
\end{tabular}

\subsection{Appendix G}

Lithostatic stress and hydrostatic pressure are estimated to better understand the conditions under which joints in the Utica Shale formed. Vertical lithostatic stress and hydrostatic pressure are estimated using the burial depth range suggested by the fluid inclusion homogenization temperatures. Vertical lithostatic stress is calculated using the following equation:

$$
\sigma_{v(l i t h o)}=\rho_{\text {litho }} \cdot g \cdot h
$$

Where $\rho_{\text {litho }}$ is the lithospheric density in $\mathrm{kg} / \mathrm{m}^{3}, g$ is the force of gravity, and $h$ is depth in $\mathrm{km}$.

Hydrostatic pressure is calculated using the following equation:

$$
P_{v(h y d r o)}=\rho_{\text {water }} \cdot g \cdot h
$$

Where $\rho_{\text {water }}$ is the density of water.

The estimates for vertical lithostatic stress are given in data table 5 and the estimates for hydrostatic pressure are provided in data table 6 . The equation for calculating vertical lithostatic stress uses a lithospheric density of $2,600 \mathrm{~kg} / \mathrm{m}^{3}$. The density value assumes that the overlying stratigraphy is composed of an equal mix of shale and sandstone. The equation for calculating hydrostatic pressure assumes a fluid density of $1,000 \mathrm{~kg} / \mathrm{m}^{3}$ and a water saturated vertical column. These parameters cannot be accurately defined because the vertical section has been 
exhumed and eroded away, yet they provide a conceptual framework for the conditions under which fractures in the Utica Shale may have formed.

\begin{tabular}{|l|l|l|l|}
\hline$\rho_{\text {litho }}\left(\mathbf{k g} / \mathbf{m}^{\mathbf{3}}\right)$ & $\boldsymbol{g}\left(\mathbf{m} / \mathbf{s}^{\mathbf{2}}\right)$ & $\boldsymbol{h}(\mathbf{k m})$ & $\sigma_{v(\text { litho })}(\mathbf{M p a})$ \\
\hline 2600 & 9.8 & 3.0 & 76 \\
\hline 2600 & 9.8 & 5.0 & 127 \\
\hline
\end{tabular}

Data Table 5: Vertical lithostatic stress estimation.

\begin{tabular}{|l|l|l|l|}
\hline $\boldsymbol{\rho}_{\text {water }}\left(\mathbf{k g} / \mathbf{m}^{\mathbf{3}}\right)$ & $\boldsymbol{g}\left(\mathbf{m} / \mathbf{s}^{2}\right)$ & $\boldsymbol{h}(\mathbf{k m})$ & $\boldsymbol{P}_{\boldsymbol{v}(\text { hydro }}(\mathbf{M p a})$ \\
\hline 1000 & 9.8 & 3 & 29 \\
\hline 1000 & 9.8 & 5 & 49 \\
\hline
\end{tabular}

Data Table 6: Hydrostatic pressure estimation. 


\subsection{Appendix H}

Utica Core 74 NY-05 description by Gordon Baird. Smith et al. 2013.

\section{Mohawk Valley 74NY05-00}



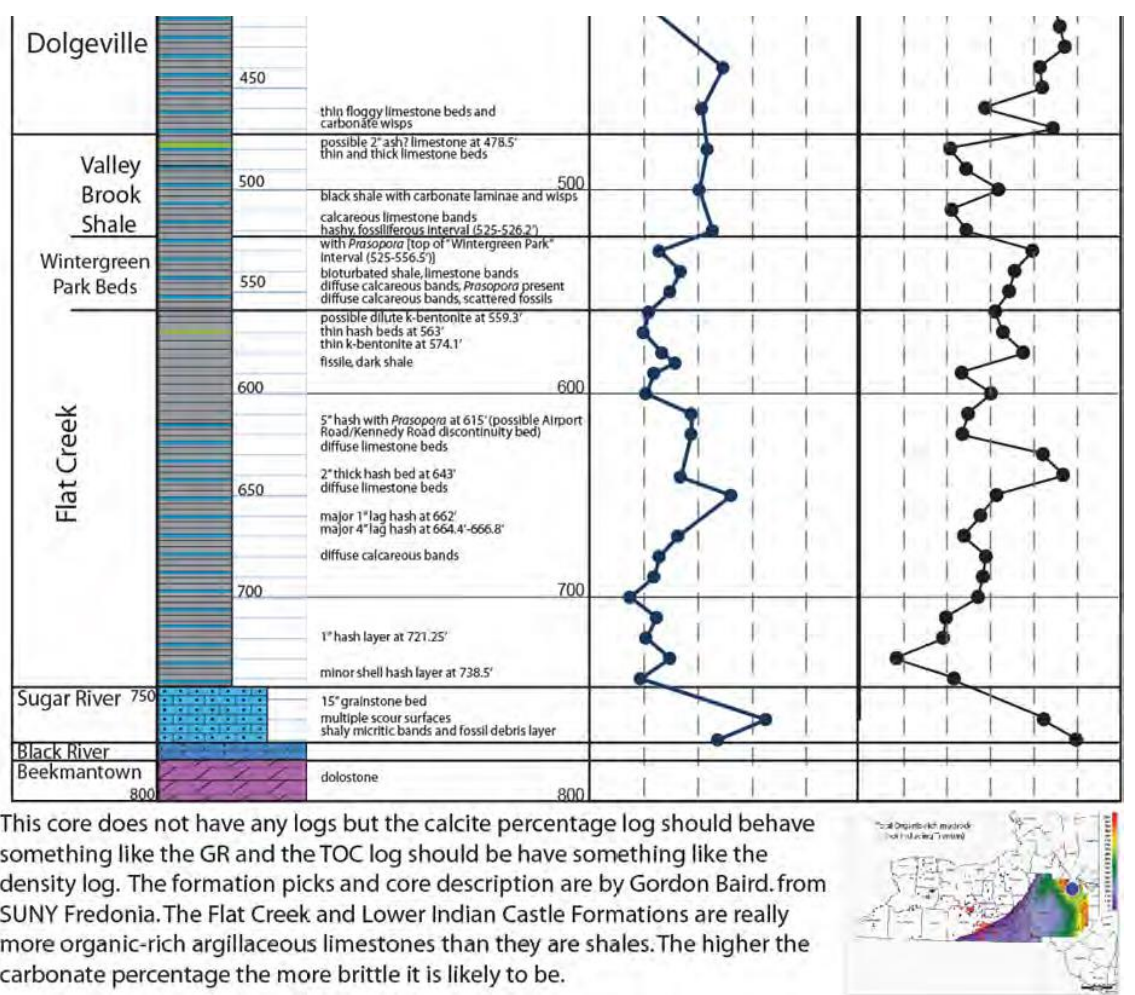

